UNIVERSIDADE DE SÃO PAULO

FACULDADE DE ECONOMIA, ADMINISTRAÇÃO E CONTABILIDADE DEPARTAMENTO DE CONTABILIDADE E ATUÁRIA PROGRAMA DE PÓS-GRADUAÇÃO EM CIÊNCIAS CONTÁBEIS

CRIAÇÃO E DISTRIBUIÇÃO DE RIQUEZA

PELA ZONA FRANCA DE MANAUS

Jorge de Souza Bispo

Orientador: Prof. Dr. Ariovaldo dos Santos 
Profa. Dra. Suely Vilela

Reitora da Universidade de São Paulo

Prof. Dr. Carlos Roberto Azzoni

Diretor da Faculdade de Economia, Administração e Contabilidade

Prof. Dr. Fábio Frezatti

Chefe do Departamento de Contabilidade e Atuária

Prof. Dr. Edgard Bruno Cornachione Junior

Coordenador do Programa de Pós-Graduação em Ciências Contábeis 
JORGE DE SOUZA BISPO

\title{
CRIAÇÃO E DISTRIBUIÇÃO DE RIQUEZA \\ PELA ZONA FRANCA DE MANAUS
}

\author{
Tese apresentada ao Departamento de \\ Contabilidade e Atuária da Faculdade de \\ Economia, Administração e Contabilidade da \\ Universidade de São Paulo como requisito \\ para a obtenção do título de Doutor em \\ Controladoria e Contabilidade.
}

Orientador: Prof. Dr. Ariovaldo dos Santos

\section{SÃO PAULO}


FICHA CATALOGRÁFICA

Elaborada pela Seção de Processamento Técnico do SBD/FEA/USP

Bispo, Jorge de Souza

Criação e distribuição de riqueza pela Zona Franca de Manaus / Jorge de Souza Bispo. - São Paulo, 2009.

$303 \mathrm{p}$.

Tese (Doutorado) - Universidade de São Paulo, 2009

Bibliografia.

1. Contabilidade social 2. Riqueza (geração) 3. Riqueza (distribuição) 4. Valor adicionado 5. Incentivo fiscal - Manaus (AM) I. Universidade de São Paulo. Faculdade de Economia, Administração e Contabilidade. II. Título.

CDD -339.2 
Para minha mãe Nair, fonte de inspiração sempre presente. 

O ato de agradecer é sempre árduo pela possibilidade de esquecimento de citar alguém que ajudou a construir o caminho, entretanto, faz-se necessário lembrar de organizações e pessoas que muito contribuíram e sem as quais não seria possível alcançar este objetivo. Peço, antecipadamente, perdão àqueles que por acaso não foram citados. À minha família, especialmente minha mãe Nair, meu pai José (In memoriam) e meus irmãos Inês, Manoel, Lourdes, Madalena, Maria José, Antonio, José Paulo, Eraldo (In memoriam) e Dalva, que sempre acreditaram e me incentivaram nessa caminhada.

À Universidade de São Paulo, que, por intermédio do Departamento de Contabilidade da FEA proporcionou a minha capacitação e evolução acadêmica.

À FIPECAFI, pela oportunidade de pesquisas proporcionadas e pelo acesso às informações do banco de dados das Melhores e Maiores empresas, sem as quais não seria possível a realização deste trabalho.

À CAPES, pelo suporte financeiro que contribuiu para a minha dedicação à pesquisa e ao ensino.

Ao Professor Doutor Ariovaldo dos Santos, pelos ensinamentos, pelas discussões, conselhos, por acreditar em meu trabalho e por ter aceitado me orientar nessa tarefa difícil. Tenha certeza de que seus questionamentos e ensinamentos me acompanharão para sempre na vida acadêmica.

Aos Professores Doutores Alexsandro Broedel Lopes e Jacqueline Veneroso Alves Cunha, pelas valiosas contribuições na qualificação e que foram fundamentais para a conclusão desta pesquisa.

Aos Professores Doutores Fábio Frezatti, Gilberto de Andrade Martins e Edgar Cornachione, pela atenção e presteza que sempre me dedicaram durante a minha vida acadêmica na FEA.

Aos Professores Doutores Bruno Meirelles Salotti, Carlos Alberto Pereira, Edson Luiz Riccio, Eliseu Martins, Geraldo Barbieri, Gerd Willi Rothmann, Iran Siqueira Lima, Joanília Neide de Sales Cia, L. Nelson G. Carvalho, Luiz João Corrar, Luiz Paulo Lopes Fávero, Reinaldo Guerreiro, Roberta Carvalho de Alencar, Valmor Slomski e Welington Rocha, pelos ensinamentos fundamentais que contribuíram para a conclusão deste trabalho.

Aos meus amigos-irmãos Jorge Calmon, Altamira (In memoriam), Ana Sumire, Carlos Burgos, Graça, Humberto, Ivelizes, Lúcia, Miguel, Nazaret, Reginaldo, Sara, Sônia (In memoriam), Suéle, Valério e Zilthai, pela confiança depositada e pelo incentivo incessante. 
Aos meus amigos Elízia, Erineide, Fabiana, Gerlando, Heloísa, Joésia, José Alves, José Elias, Laura, Lilica, Lourdes Dantas, Lourdes Nakamura, Mônica, Nivaldo, Núbia, Patrícia Vieira, Rosana, Tatiana, por estarem sempre presentes, pelas palavras de incentivo e pelas contribuições.

Aos meus colegas de Doutorado e Mestrado, especialmente Emanuel, Fernanda Furuta, Flávia, Formigoni, Mara Jane, Márcio Belli, Mariana, Patrícia Varella, Romildo, Bleise, Bruna Casela, Camila, Carmine, Cecília, Chiqueto, Daniel, Guilherme Beloque, Guilhermo, Mychelle, Reinaldo, Roberto Suzuki, pela agradável convivência durante as aulas e pelas excelentes e constantes trocas de ideias.

À Regina Valbom, pela formatação, ao Prof. José Carlos de Aquino pela revisão gramatical e ortográfica e a Luiz Cioffi (Kitola) juntamente com sua equipe pela presteza no atendimento diário.

Aos meus amigos da FEA, Aparecida, Belinda, Cid, Cristina, Eliene, Evandro, Francisco, Marilda, Matias, Melissa, Nilson, Rodolfo e Valéria, que facilitaram o percurso da minha vida acadêmica dentro da FEA.

E, finalmente, a todos que, direta ou indiretamente, contribuíram para a realização deste projeto de vida.

A todos, meus mais profundos e sinceros agradecimentos. 
"Ninguém ignora tudo. Ninguém sabe tudo.

Todos nós sabemos alguma coisa.

Todos nós ignoramos alguma coisa.

Por isso aprendemos sempre."

Paulo Freire 



\section{RESUMO}

Este trabalho avalia os efeitos dos incentivos fiscais concedidos às indústrias instaladas na Zona Franca de Manaus na criação e distribuição de riqueza. A plataforma teórica tem como pilares as teorias sobre comércio exterior e a dos stakeholders, aliadas aos conceitos relativos às políticas de desenvolvimento econômico, às políticas de desenvolvimento industrial e aos incentivos fiscais. O modelo industrial Zona Franca de Manaus é caracterizado como Zona de Livre Comércio. Discute-se os conceitos, vantagens, desvantagens da Demonstração de Valor Adicionado (DVA) como instrumento contábil para medir a criação e distribuição de riqueza. A amostra deste estudo foi selecionada entre as indústrias instaladas na ZFM que publicam as demonstrações financeiras do banco de dados mantidos pela FIPECAFI, base para a edição Melhores e Maiores, da Revista Exame. Dentre essas empresas foram selecionadas 30 (trinta) para análise quanto à forma de contabilização dos incentivos fiscais, totalizando 150 (cento e cinquenta) demonstrações contábeis no período de 2003 a 2007. Para a análise de criação e distribuição de riqueza foram selecionadas todas as indústrias que elaboram e/ou divulgam a Demonstração de Valor Adicionado (DVA). Foram analisadas ao total 73 Demonstrações de Valor Adicionado para o período de 2003 a 2007 e comparadas a criação e a distribuição de riqueza com outros grupos de indústrias, localizados fora da Zona Franca de Manaus. Foram analisados os setores de autoindústria, bens de consumo e indústrias digital e de eletroeletrônicos e um grupo de controle de empresas pares, escolhidas em função da similaridade do setor de atuação e faturamentos. Para a comparação da forma de contabilização dos incentivos fiscais, especificamente o ICMS, foi utilizada a técnica de análise de conteúdo e estatística descritiva entre os grupos que contabilizam de forma correta e os que contabilizam de forma errada. Foram encontradas quatro formas de contabilização, nas quais se destacam $66,7 \%$ que contabilizam de forma errada e $20 \%$ de forma correta. Para a análise da criação de riqueza pelas empresas foram utilizadas as técnicas estatística análise de regressão e teste de média. Pela técnica de regressão linear as empresas industriais instaladas na Zona Franca de Manaus criam, em média, 30,96\% de riqueza em função do faturamento, enquanto as empresas pares situadas fora dessa região criam, em média, 45,08\%. Ao aplicar o teste de média, as empresas situadas na Zona Franca de Manaus, criam, em média $31,07 \%$ ao passo que as empresas pares situadas fora criam, em média, 54,36\%. Destaque-se o fato de que as empresas industriais instaladas na Zona Franca de Manaus que contabilizam os incentivos fiscais, de maneira errada, especificamente o ICMS, evidenciam e publicam, de maneira equivocada, a criação de riqueza, em média, de $42,85 \%$ pela regressão linear e $32,41 \%$ pela média. Para a distribuição de riqueza foi pesquisada a distribuição para três grupos: pessoal, governos e proprietários. Foi utilizado o teste de média e os achados mostram que enquanto as empresas industriais instaladas na ZFM distribuem 27,28\%, 54,42\% e $1,82 \%$ aos empregados, governos e proprietários, respectivamente, as empresas pares situadas fora distribuem $36,31 \%, 41,54 \%$ e $6,44 \%$, respectivamente. Os resultados finais da pesquisa chegam à conclusão que os incentivos fiscais concedidos pelo modelo industrial Zona Franca de Manaus às indústrias instaladas naquela região criam menos riqueza do que os mesmos setores ou similares instalados fora e sem os incentivos fiscais e distribuem menos riqueza aos empregados e aos proprietários, mas possuem efeitos positivos na parcela de riqueza distribuída aos governos, em função da riqueza criada. 


\section{ABSTRACT}

This thesis assesses the effects of tax incentives granted to industrial enterprises located at the Manaus Free Trade Zone as far as generation and distribution of wealth goes. The theories of foreign trade and of stakeholders are the foundation, alongside concepts concerning policies of industrial development and tax incentives. The Free Trade Zone industrial model is characterized as a zone of free trade in its own right. Topics of discussion include the concepts, advantages, and disadvantages of Value Added Statements (VAS) as an accounting tool to measure the creation and distribution of wealth. The research sample was selected among the enterprises operating within MFTZ that disclose financial statements at the database kept by Fipecafi, which in turn feeds the issues of "Maiores e Melhores", published by Exame Magazine. Thirty enterprises were then selected for analysis as to the way of accounting tax incentives, totaling 150 (a hundred and fifty) accounting statements in the period comprised between 2003 and 2007. All the industrial enterprises which produce and/or publish Value Added Statements were used in the part dedicated to the analysis of creation and distribution of wealth. On the whole, seventy three Value Added Statements were studied for the 2003-2007 period, and these were compared with the creation and distribution of wealth by other enterprises selected and set up outside Manaus Free Trade Zone. The sectors selected were automobile, consumer goods, digital products, and electric-electronic goods, together with a counterpart control group, chosen due to similarities in type of product and income. In order to compare the way tax incentives, in special ICMS (Value Added Tax on Sale and Services) are accounted, the content technique and the descriptive analysis were used with both, the groups that account these incentives correctly and the ones that do so incorrectly. Four accounting possibilities were found, and among them the emphasis lies on a $66.7 \%$ of wrong accounting manner, and a $20 \%$ of correct accounting manner. In order to perform the analysis of wealth creation by enterprises, the study resorted to regression analysis and mean test. The linear regression technique showed that industrial enterprises within MFTZ generate around 30.96\% of wealth due to income, while counterpart enterprises located elsewhere generate an average $45.08 \%$. The mean test demonstrates that enterprises located within the MFTZ create an average $31.07 \%$, whereas the control group generates an average $54.39 \%$ wealth. It must be emphasized that enterprises that are placed within MFTZ, account tax incentives, especially ICMS incorrectly, disclose and publish wealth creation in the wrong way are an average $42.85 \%$ by linear regression and an average $32.41 \%$ by mean test. As to wealth distribution, three groups of recipients of wealth produced were analyzed: employees, governments, and shareholders. The mean test was used and the findings show that whereas enterprises in MFTZ dispense 27.85, 54.42\%, and $1.82 \%$ respectively to employees, governments and shareholders, the control group distributes $36.31 \%, 41.54 \%$, and $6,44 \%$ respectively. The final results of the research point to the conclusion that tax incentives granted by the industrial model of Manaus Free Trade Zone to enterprises located in that region generate less wealth than counterpart enterprises located outside the zone and which do not benefit from those incentives; besides, they distribute less wealth to employees and shareholders, but perform positively as to share of wealth granted to governments due to the wealth created. 



\section{SUMÁRIO}

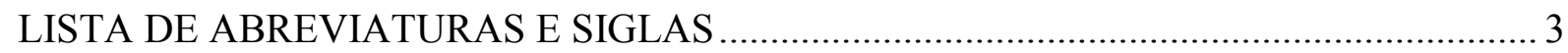

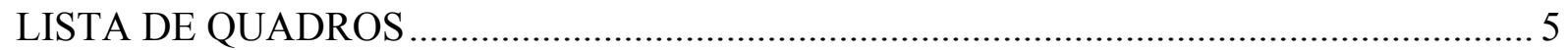

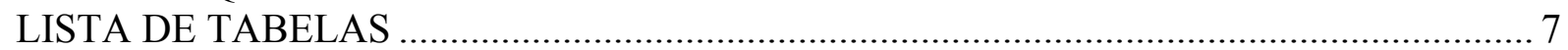

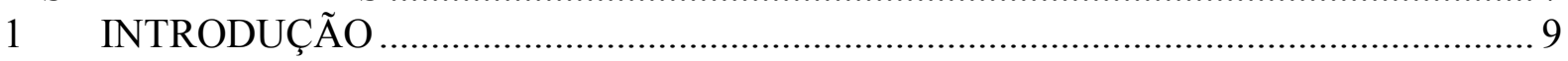

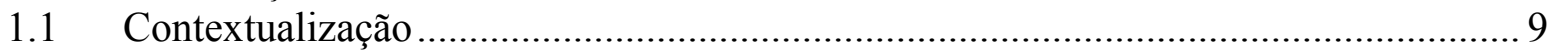

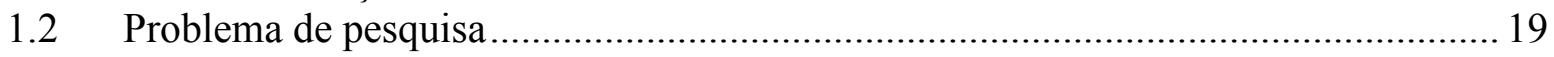

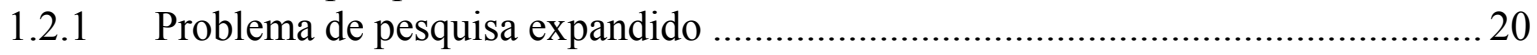

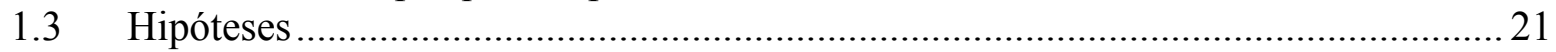

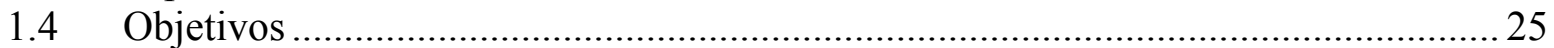

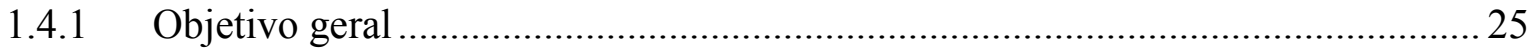

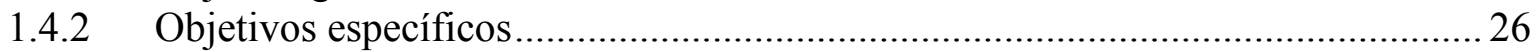

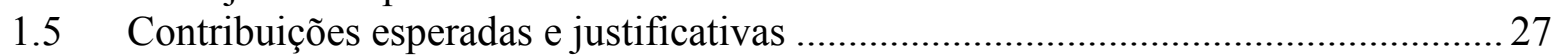

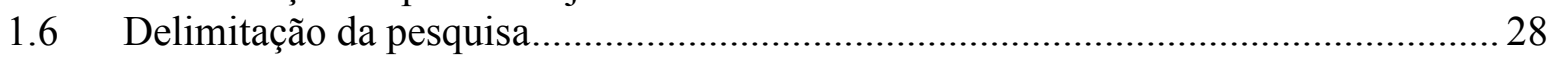

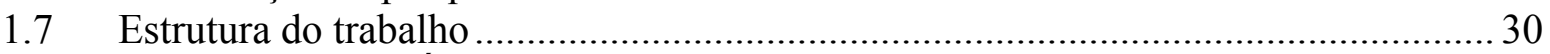

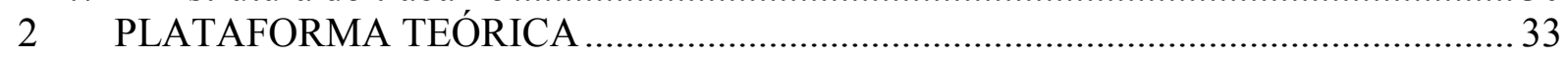

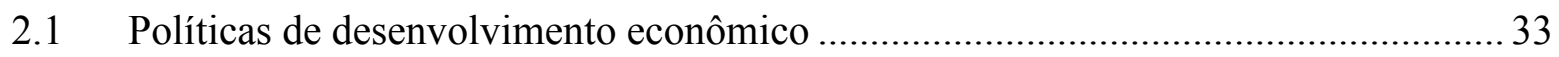

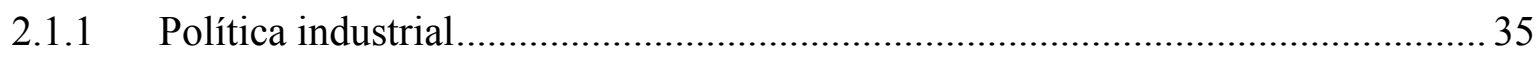

2.1.2 Conceituação e importância dos subsídios e incentivos fiscais ............................ 41

2.1.3 Zonas de Livre Comércio ................................................................................... 47

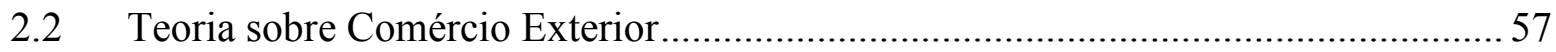

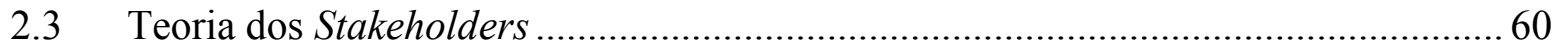

2.4 A Demonstração de Valor Adicionado (DVA) …........................................................ 72

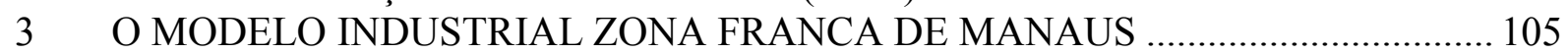

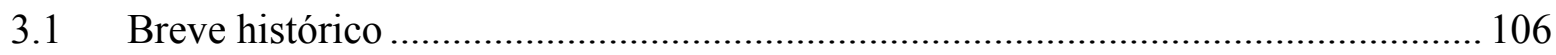

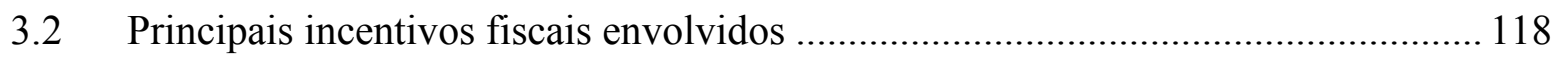

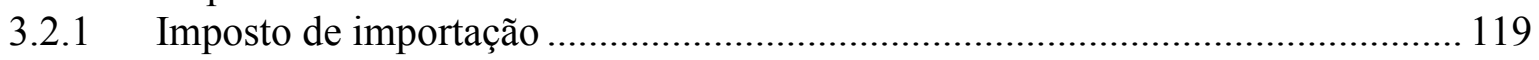

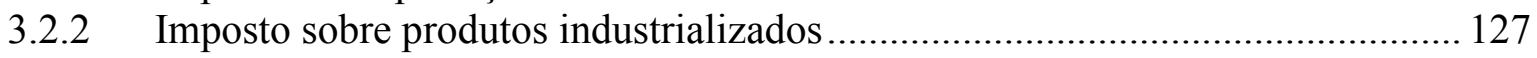

3.2.3 Imposto sobre circulação de mercadorias e serviços........................................... 128

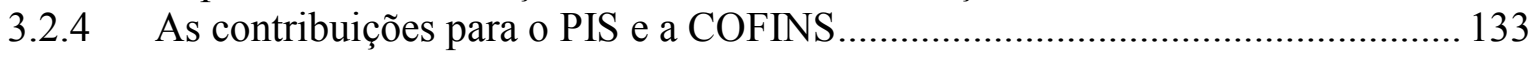

3.3 A formação de preço e as variáveis de custos........................................................... 135

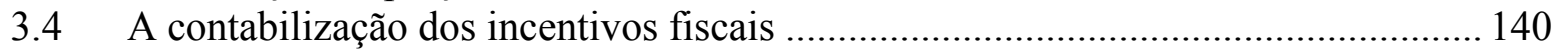

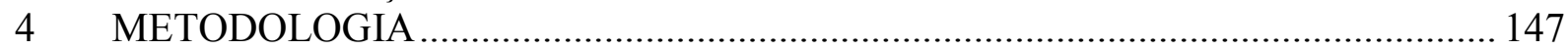

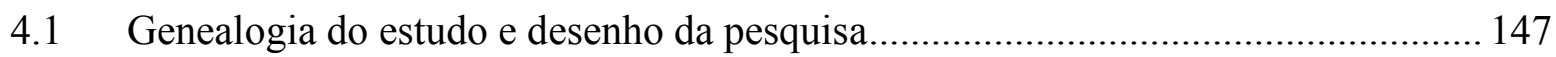

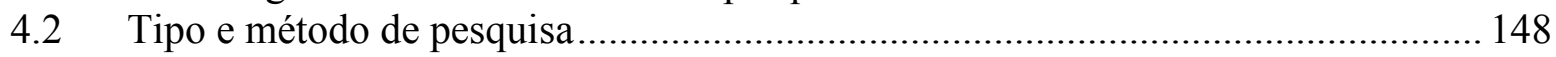

4.3 Escolha e definição da população-alvo e amostra............................................... 149

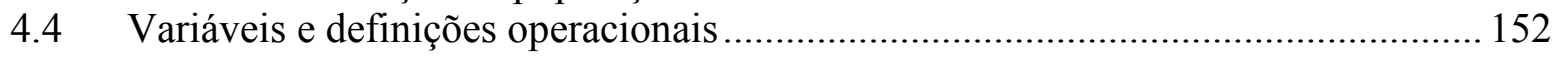

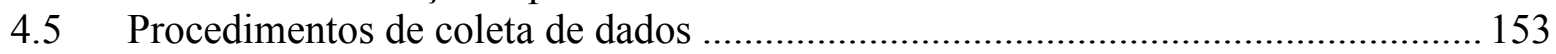

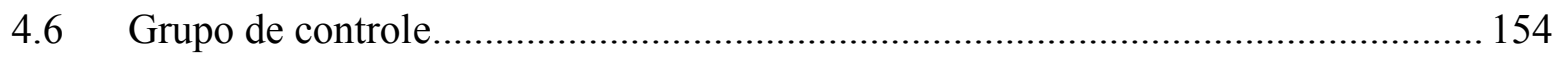

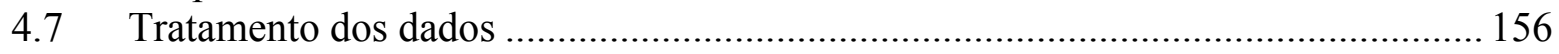

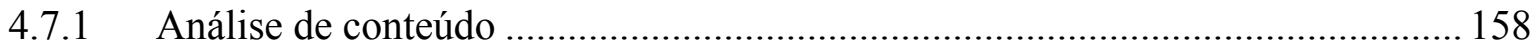

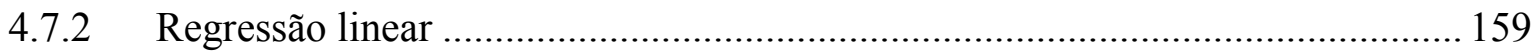

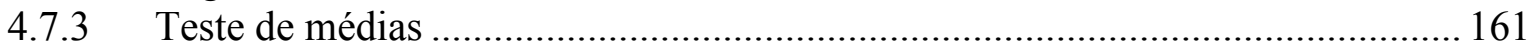

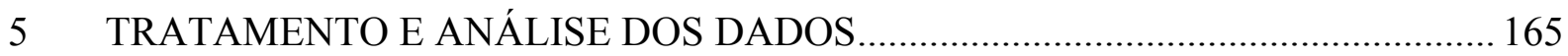

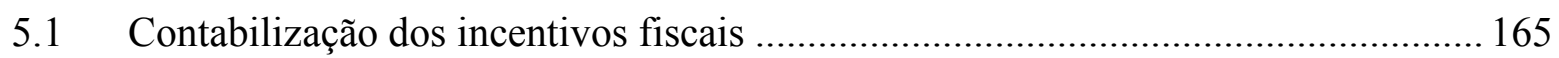

5.2 Criação de riqueza pela Zona Franca de Manaus .................................................... 173

5.3 Distribuição de riqueza pela Zona Franca de Manaus ............................................ 184 


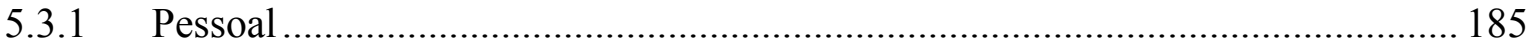

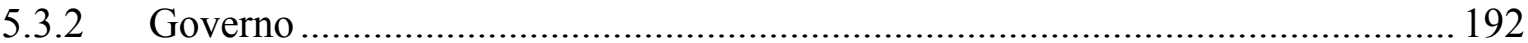

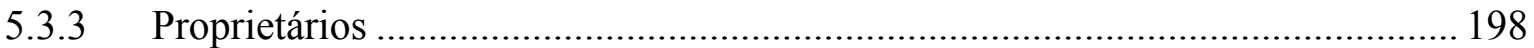

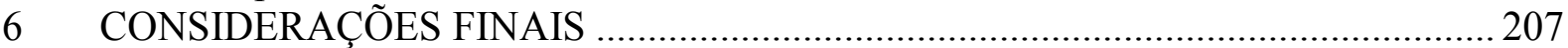

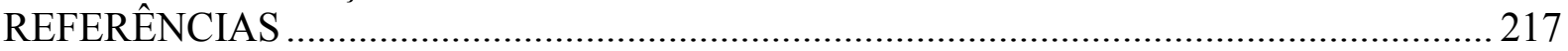

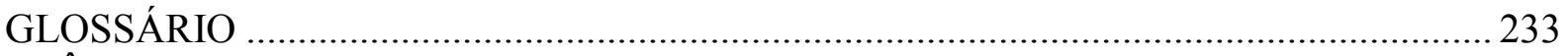

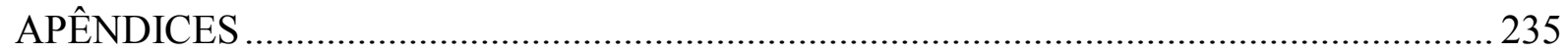




\title{
LISTA DE ABREVIATURAS E SIGLAS
}

\author{
ABRASCA: Associação Brasileira das Companhias Abertas \\ ADCT: Ato das Disposições Constitucionais Transitórias \\ ADIN: Ação Direta de Inconstitucionalidade \\ AICPA: American Institute of Certified Public Accountants (Instituto Americano dos \\ Contadores Públicos Certificados) \\ ANEEL: Agência Nacional de Energia Elétrica \\ APIMEC: Associação dos Analistas e Profissionais de Mercado de Capitais \\ BOVESPA: Bolsa de Valores de São Paulo \\ CDI: Conselho de Desenvolvimento Industrial \\ CF: Constituição Federal \\ CFC: Conselho Federal de Contabilidade \\ CLT: Consolidação das Leis do Trabalho \\ CODAM: Conselho de Desenvolvimento do Estado do Amazonas \\ COFINS: Contribuição Social para Financiamento da Seguridade Social \\ COSIT: Coordenação Geral do Sistema de Tributação \\ CPC: Comitê de Pronunciamentos Contábeis \\ CTN: Código Tributário Nacional \\ CVM: Comissão de Valores Mobiliários \\ DCI: Declaração de Controle de Internação \\ DCR: Demonstrativo de Coeficiente de Redução \\ DCR-E: Demonstrativo de Coeficiente de Redução - Eletrônico \\ DI: Declaração de Importação \\ DRE: Demonstração de Resultado do Exercício \\ DVA: Demonstração de Valor Adicionado \\ FASB: Financial Accounting Standards Board \\ FGTS: Fundo de Garantia por Tempo de Serviço \\ FIESP: Federação das Indústrias do Estado de São Paulo \\ FIPECAFI: Fundação Instituto de Pesquisas Contábeis, Atuariais e Financeiras \\ FMPES: Fundo de Apoio às Micro e Pequenas Empresas e ao Desenvolvimento Social do \\ Estado do Amazonas
}

FOB: Free on Board - Livre a Bordo

FTI: Fundo de Turismo e Interiorização

FTZ: Free Trade Zone (Zona de Livre Comércio)

GATT: General Agreement on Tariffs and Trade (Acordo Geral sobre Tarifas e Comércio)

IBRACON: Instituto dos Auditores Independentes do Brasil

ICMS: Imposto sobre Circulação de Mercadorias e sobre a prestação de serviços de transportes interestadual e intermunicipal e de comunicações.

IGPM: Índice Geral de Preços do Mercado

II: Imposto de Importação

IN: Índice de Nacionalização

IN: Instrução Normativa

INSS: Instituto Nacional de Seguridade Social

IPEA: Instituto de Pesquisa Econômica Aplicada

IPI: Imposto sobre Produtos Industrializados

MDIC: Ministério do Desenvolvimento, Indústria e Comércio Exterior

NBC: Normas Brasileiras de Contabilidade

NCM: Nomenclatura Comum do Mercosul 
OCDE: Organização para a Cooperação e Desenvolvimento Econômico

OMC: Organização Mundial do Comércio

ONG: Organização Não Governamental

PIB: Produto Interno Bruto

PIS: Programa de Integração Social

PND: Plano Nacional de Desenvolvimento

PPB: Processo Produtivo Básico

PTAX: Taxa de Câmbio

RA: Regulamento Aduaneiro

RFB: Receita Federal do Brasil

RIPI: Regulamento do Imposto sobre Produtos Industrializados

RIR: Regulamento do Imposto de Renda

SEPLAN: Secretaria do Estado de Planejamento e Desenvolvimento Econômico

SEZ: Special Economic Zone (Zona Econômica Especial)

SH: Sistema Harmonizado

SRF: Secretaria da Receita Federal do Brasil

STF: Supremo Tribunal Federal

SUFRAMA: Superintendência da Zona Franca de Manaus

SUSEP: Superintendência de Seguros Privados

UEA: Universidade do Estado do Amazonas

VAT: Value Added Tax (Imposto sobre Valor Agregado)

ZEE: Zona Econômica Especial

ZEL: Zona Econômica Livre

ZF: Zona Franca

ZFM: Zona Franca de Manaus

ZLC: Zona de Livre Comércio

ZLI: Zona Livre de Impostos

ZPE: Zona de Processamento de Exportação 


\section{LISTA DE QUADROS}

Quadro 1 - Classificação das Zonas de Livre Comércio 48

Quadro 2 - Principais mudanças de relacionamento entre partes interessadas primárias e as empresas

Quadro 3 - Principais mudanças de relacionamentos entre as partes interessadas secundárias e as empresas

Quadro 4 - Dez princípios para gerenciamento de relacionamentos com as partes interessadas

Quadro 5 - Níveis de importância dados pelas partes interessadas a alguns itens .............. 72

Quadro 6 - Estrutura da Demonstração de Valor Adicionado ............................................. 99

Quadro 7 - Estrutura da Demonstração de Valor Adicionado aprovada pelo CPC........... 103

Quadro 8 - Fases históricas da Zona Franca de Manaus ................................................... 106

Quadro 9 - Demonstração de cálculo do imposto de importação reduzido de um Televisor 21'- redutor fixo.

Quadro 10 - Demonstração de cálculo do imposto de importação reduzido de uma motocicleta, modelo 125 - redutor fixo

Quadro 11 - Demonstração de cálculo do imposto de importação reduzido de uma unidade digital de processamento de pequeno porte - redutor variável

Quadro 12 - Esquema de contabilização dos incentivos fiscais do ICMS em conta vinculada

Quadro 13 - Esquema de contabilização dos incentivos fiscais do ICMS

Quadro 14 - Esquema de contabilização dos incentivos fiscais do ICMS na ZFM .......... 144

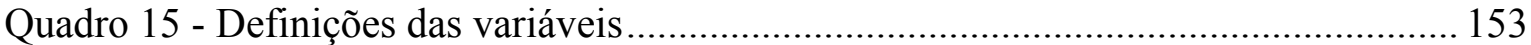

Quadro 16 - Síntese dos objetos de pesquisa, grupos de pesquisas e de controle .............. 156

Quadro 17 - Descrição das Formas de Contabilização do Incentivo Fiscal do ICMS ....... 166

Quadro 18 - Demonstração de Resultado do Exercício de acordo com a forma

de contabilização "A" - 31/12/2007

Quadro 19 - Esquema real de contabilização dos incentivos fiscais do ICMS

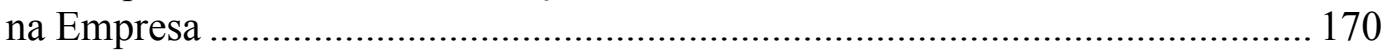

Quadro 20 - Demonstração de resultado do exercíciode acordo com a forma de contabilização "B" - 31/12/2007

Quadro 21 - Esquema real de contabilização dos incentivos fiscais do ICMS na empresa.

Quadro 22 - Demonstração de resultado do exercício de acordo com a forma de contabilização "C" - 31/12/2007

Quadro 23 - Esquema real de contabilização dos incentivos fiscais do ICMS na empresa.

Quadro 24 - Criação de riqueza das DVAs Consolidadas (\%) ........................................ 183

Quadro 25 - Distribuição de riqueza aos empregados das DVAs Consolidadas (\%)........ 190

Quadro 26 - Distribuição de riqueza aos governos das DVAs Consolidadas (\%) ............ 197

Quadro 27 - Distribuição de riqueza aos proprietários das DVAs Consolidadas (\%)....... 204 



\section{LISTA DE TABELAS}

Tabela 1 - Faturamento da Zona Franca de Manaus - 2003-2007 ..................................... 13

Tabela 2 - Criação de empregos pela Zona Franca de Manaus - 2003-2007 ....................... 14

Tabela 3 - Balança comercial da Zona Franca de Manaus - 2003-2007 .............................. 14

Tabela 4 - Participação dos gastos tributários no PIB - 2003-2007 (R\$ milhões) ............... 15

Tabela 5 - Distribuição dos gastos tributários (benefícios) por modalidade de incentivo

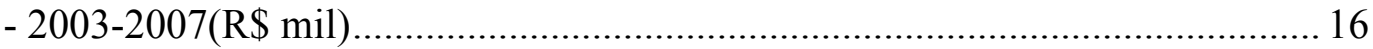

Tabela 6 - Participação dos principais gastos tributários (benefícios) no total do PIB

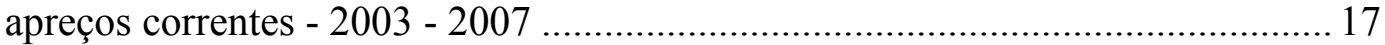

Tabela 7 - Número de DVAs publicadas no Brasil - 1997 - 2007...................................... 82

Tabela 8 - Principais produtos produzidos e vendidos pela Zona Franca de Manaus em 2007

Tabela 9 - Participação dos principais setores no faturamento da Zona Franca de Manaus- 2003 - 2007

Tabela 10 - Produto Interno Bruto a preços correntes e Produto Interno Bruto per capita, segundo as grandes regiões e unidades da federação - 2003 - 2006

Tabela 11 - Crescimento do Produto Interno Bruto das principais cidades brasileiras - 2006/2003

Tabela 12 - Produto Interno Bruto a preços correntes e participação das principais cidades brasileiras nas regiões e no país - 2006

Tabela 13 - Arrecadação de tributos federais, arrecadação de tributos federais

per capita e participação das unidades da federação no total por região $-2006$

Tabela 14 - Relação entre arrecadação e PIB de alguns estados brasileiros - 2003-2006. 116

Tabela 15 - Arrecadação de tributos federais por alguns estados brasileiros-2003-2007 . 117

Tabela 16 - Demonstração do cálculo de crédito estímulo e ICMS apagar ....................... 133

Tabela 17 - Demonstração das variáveis de custos que impactam no preço ...................... 139

Tabela 18 - Vendas conjuntas das maiores empresas industriais da Zona Franca de

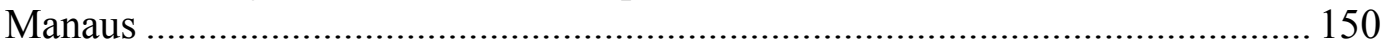

Tabela 19 - Empresas amazonenses com demonstrações contábeis disponíveis ............... 151

Tabela 20 - Empresas industriais amazonenses com demonstrações contábeis disponíveis

Tabela 21 - Empresas industriais Amazonenses com Demonstração de Valor

Adicionado disponíveis em US\$ de 31/12/2007

Tabela 22 - Empresas da ZFM que divulgaram as demonstrações contábeis

- 2003-2007

Tabela 23 - Formas de contabilização dos incentivos fiscais.

Tabela 24 - Distribuição percentual das empresas industriais da ZFM de acordo

com as formas de contabilização dos incentivos fiscais \% …........................... 168

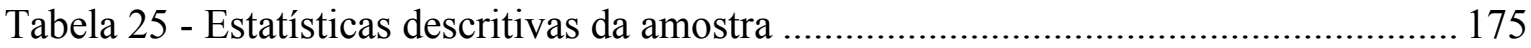

Tabela 26 - Regressões das empresas da Zona Franca de Manaus ................................. 175

Tabela 27 - Estatísticas descritivas da amostra de empresas pares .................................. 177

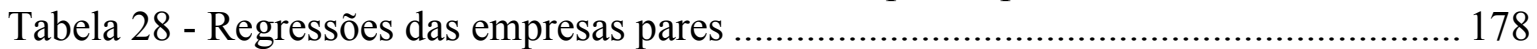

Tabela 29 - Estatísticas descritivas da amostra das empresas da ZFM e empresaspares .. 178

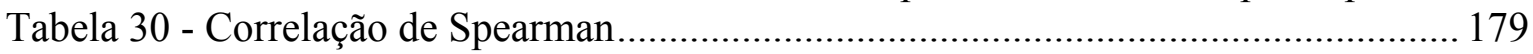

Tabela 31 - Regressões empresas ZFM e empresas pares.............................................. 179

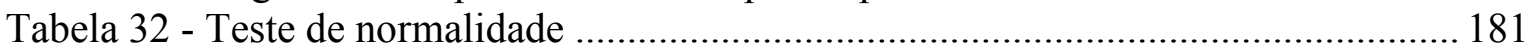

Tabela 33 - Teste de média das amostras emparelhadas ................................................. 181 
Tabela 34 - Teste de média do valor adicionado de amostras emparelhadas .................... 182

Tabela 35 - Estatísticas descritivas para o valor adicionado distribuído a pessoal ........... 185

Tabela 36 - Teste de média do valor adicionado distribuído a pessoal entre o grupo

ZFM T e outros grupos

Tabela 37 - Teste de média do valor adicionado distribuído a pessoal entre o grupo

ZFM_C e outros grupos

Tabela 38 - Teste de média do valor adicionado distribuído a pessoal entre o grupo

ZFM_Ee outros grupos.

Tabela 39 - Teste de média do valor adicionado distribuído a Pessoal de amostras

emparelhadas

Tabela 40 - Estatísticas descritivas para o valor adicionado distribuído ao governo ......... 192

Tabela 41 - Teste de média do valor adicionado distribuído aos governos entre o grupo ZFM_T e outros grupos

Tabela 42 - Teste de média do valor adicionado distribuído aos governos entre o grupo ZFM_Ce outros grupos .

Tabela 43 - Teste de média do valor adicionado distribuído aos governos entre o grupo ZFM_Ee outros grupos

Tabela 44 - Teste de média do valor adicionado distribuído aos governos de amostras emparelhadas

Tabela 45 - Estatísticas descritivas para o valor adicionado distribuído aos acionistas.... 199

Tabela 46 - Teste de média do valor adicionado distribuído aos proprietários entre o

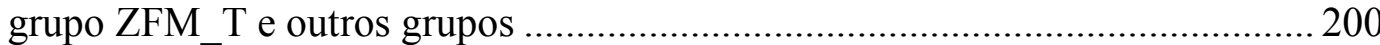

Tabela 47 - Teste de média do valor adicionado distribuído aos proprietários entre o grupo ZFM_C e outros grupos

Tabela 48 - Teste de média do valor adicionado distribuído aos proprietários entre o grupo ZFM_E e outros grupos

Tabela 49 - Teste de média do valor adicionado distribuído aos proprietários de amostras emparelhadas. 


\section{INTRODUÇÃ̃O}

Esse capítulo encarrega-se de apresentar a parte introdutória da tese, em que é feita uma breve análise conjuntural do ambiente no qual se insere o problema de pesquisa. Para fins de ilustração, são mostrados alguns dados sobre a importância do modelo Zona Franca de Manaus e a participação relativa desse modelo no total dos incentivos concedidos pelo Governo Federal. Em seguida, definem-se os objetivos gerais e específicos bem como as hipóteses de pesquisas a serem testadas. $\mathrm{Na}$ parte final do capítulo, apresentam-se as limitações, as justificativas e a importância do tema.

\subsection{Contextualização}

A região norte, mais especificamente o Estado do Amazonas, passou por um período de estagnação econômica desde o início do século 20, com o desaquecimento do ciclo da borracha, até os anos 60 com a instalação da Zona Franca de Manaus. A distância dos grandes centros consumidores, a dificuldade de acesso, a escassez de infraestrutura e de recursos logísticos, a falta de mão de obra qualificada, dentre outros aspectos, faziam com que a região não oferecesse atrativos para a instalação de empreendimentos que pudessem contribuir para promover o seu desenvolvimento.

Com a incapacidade do mercado em resolver todos os problemas econômicos, torna-se necessária a ação do Estado que, segundo Andrade (2008, p.254), implica na

[...] necessidade de se elaborar políticas econômicas que afetam a repartição dos rendimentos e do consumo e orientam as decisões que o governo deve tomar e indiquem as intervenções que deve eventualmente realizar. Com essas políticas procura-se, pois, (i) evitar a desagregação do Estado por meio da eclosão de conflitos internos e (ii) promover, a um só tempo, o aumento da riqueza nacional, o uso eficiente dos fatores de produção e a distribuição equânime dos rendimentos econômicos.

Dessa forma, segundo de Ribeiro (2008, p. 331), "Com a predominância do modelo do Estado Social, não se pode abrir mão do uso dos tributos como eficazes instrumentos de política e de atuação estatal, nas mais diversas áreas, sobretudo na social e na econômica [...]." Logo, ao tratar de política pública de desenvolvimento nacional e ao apresentar o uso de instrumentos de incentivos fiscais para opções de políticas econômicas, Andrade (2008, p. 255) esclarece que, 
Opções de políticas econômicas que, por serem instrumentadas por normas jurídicas, acabam tendo relevância jurídica, na medida em que as políticas econômicas visando à melhoria da eficiência econômica e a distribuição equânime dos rendimentos utilizam os instrumentos fornecidos pelo direito para, por meio de um conjunto de regras jurídicas, organizar, de modo eficiente, o uso dos fatores de produção.

$\mathrm{Na}$ mesma linha de raciocínio, Andrade (2008, p. 269) pondera que a política de desenvolvimento não deve ser reduzida a incentivos fiscais; deve existir maior presença da União para ampliar a eficácia das medidas implantadas.

É nesse contexto que Rodrigues (2007, p. 300) apresenta a utilização dos incentivos fiscais como política de desenvolvimento econômico, ao citar a criação da Zona Franca de Manaus:

Uma das formas de promover o desenvolvimento de regiões menos desenvolvidas do País é, sem dúvida, a redução ou eliminação de encargos de ordem fiscal, como ocorreu em relação à criação da Zona Franca de Manaus, pela Lei n. 3.173/57, alterada pelo Decreto-Lei n. 288/67, mantida pela constituição de 1988, na forma do art. 40 do ADCT.

Ao definir a Zona Franca de Manaus como instrumento de promoção e desenvolvimento regional, Furlan (2008) amplia a sua definição ao complementar que a Zona Franca de Manaus não constitui um efetivo regime de zona franca porque possui características de área de livre comércio, área de zona franca, área de incentivos especiais (consumo interno), área qualificada como receptora de um pólo industrial e área de disseminação de desenvolvimento econômico.

A discussão sobre a concordância e validade dos incentivos fiscais proporcionados pelo modelo industrial Zona Franca de Manaus aos investimentos instalados naquela região é uma constante nos meios empresariais. A validade do modelo não é consenso entre os governos federal e estaduais e entre o meio empresarial. A corrente contrária alega que incentiva a concorrência desleal e provoca a guerra fiscal, de acordo com o pensamento expresso pela Federação das Indústrias do Estado de São Paulo (Fiesp) ao negar espaço à SUFRAMA, em 2002, para realização de evento promocional dos 35 anos de criação da Zona Franca de Manaus, ao expor que setores do empresariado paulista desaprovam "certas distorções de mercado" e a concorrência dos produtos fabricados com incentivos fiscais em Manaus. ${ }^{1}$

\footnotetext{
1 Reportagem Fiesp nega espaço para exposição da ZFM em São Paulo, Gazeta Mercantil, 11/04/2002. Disponível em HTTP://indexet.gazetamercantil.com.br/arquivo/2002/04/11.
} 
A Zona Franca de Manaus foi criada pela Lei n. 3.173, de 06 de janeiro de 1957, porém, somente em 1967, por meio do Decreto-lei n. 288, de 28 de fevereiro de 1967, é que, de fato, foi instituída com o objetivo de estabelecer um polo de desenvolvimento comercial, industrial e agropecuário, visando a integrar a Amazônia à economia do país, a promover a melhor integração produtiva e social dessa região, além de garantir a soberania nacional sobre as suas fronteiras com países vizinhos.

Na sua instalação, os incentivos fiscais foram concedidos pelo prazo de trinta anos, de acordo com o artigo 42 do Decreto-lei n. 288. Por época da promulgação da Constituição Federal de 1988, que recepcionou os dispositivos legais vigentes, nos atos das disposições constitucionais transitórias, foi estabelecido o prazo de vinte e cinco anos, a partir da promulgação da Carta Magna, o que terminaria em 2013. Posteriormente, por meio da Emenda Constitucional n. 42, de 19 de dezembro de 2003, foram acrescidos dez anos ao prazo que terminaria em 2013, passando sua vigência até 2023.

Inicialmente, a atividade comercial teve destaque em virtude da sua caracterização como Zona de Livre Comércio, atividade contemplada pelo mesmo Decreto-lei de criação e que teve papel preponderante até o final da década de 80. Entretanto, com a abertura do País ao comércio internacional, no início dos anos 90, essa atividade veio perdendo competitividade, chegando ao patamar de $2,5 \%{ }^{2}$ das atividades da Zona Franca de Manaus.

Por outro lado, com a perda de importância das atividades comerciais, o polo industrial veio aumentando sua participação e importância, constituindo, hoje, a base de sustentação do modelo, contando com empresas que apresentam elevados níveis de faturamento e índices de inovação, produtividade, modernos métodos de gestão e modernos parques tecnológicos.

O modelo de desenvolvimento industrial da Zona Franca de Manaus está alicerçado em Incentivos Fiscais e Extra-Fiscais concedidos às empresas que lá se instalam. Para obter a concessão desses incentivos, a empresa necessita apresentar um projeto econômico com requisitos financeiros, sociais e ambientais, além de cumprir um Processo Produtivo Básico (PPB), que se define como um conjunto mínimo de operações a serem praticadas pelas

\footnotetext{
${ }^{2}$ Disponível em: <http:www.suframa.gov.br>. Acesso em: 17/09/2008.
} 
empresas industriais beneficiárias. A ideia é permitir a absorção de tecnologia, alavancar o processo de crescimento e desenvolvimento da região onde a empresa se localiza.

Silva (2003, p. 6), ao analisar a política industrial e interesses empresariais do II PND, ratifica o pensamento contrário ao modelo ZFM, afirmando:

A nacionalização da produção na Zona Franca foi um exemplo da atuação de setores da indústria na defesa de seus interesses. A Zona Franca de Manaus, como área de tributação diferenciada das importações, foi sempre um problema para a indústria eletro-eletrônica, devido à possibilidade que representava de instalação de empresas cuja produção se baseasse na simples montagem de produtos elétricos e eletrônicos e com peças importadas. As gestões da Abinee visavam, portanto, à normatização das atividades desenvolvidas na Zona Franca, principalmente por meio da fixação de índices de nacionalização para a produção na região.

A sobrevivência do modelo ZFM depende de legislações federal, estaduais e municipais, razão pela qual, de tempos em tempos, outras unidades da Federação questionam a sua importância e validade. Argumenta-se que a ZFM não passa de um entrave econômico oneroso para o país e suas indústrias, uma vez que os incentivos fiscais (isenções e reduções) não são cobertos pelos impostos pagos. Por outro lado, os defensores do modelo contraargumentam apresentando os dados de arrecadação federal, estadual e municipal, além de outros indicadores sociais, dentre eles, o faturamento das empresas instaladas na Zona Franca de Manaus e o número de empregos gerados.

A fim de ilustrar a importância desse modelo industrial de desenvolvimento econômico baseado em incentivos fiscais, torna-se necessária a exemplificação de alguns dados, como faturamento das empresas industriais, número de empregos gerados, volume de importações e de exportações, dentre outros.

Com relação ao faturamento das empresas industriais que estão instaladas na Zona Franca de Manaus, observa-se que o volume de faturamento, em 2007, foi de US\$ 28,277 bilhões, conforme mostra a Tabela 1, destinados ao mercado interno (consumo na própria Zona Franca de Manaus e restante do Brasil) e ao mercado externo. 
Tabela 1 - Faturamento da Zona Franca de Manaus - 2003-2007

\begin{tabular}{c|r|r}
\hline Anos & Valor US\$ mil $^{(\mathbf{1})}$ & \multicolumn{1}{|c}{$\begin{array}{c}\text { Valor US\$ mil de } \\
\mathbf{3 1 . 1 2 . 2 0 0 7}\end{array}$} \\
\hline 2003 & 10.531 .230 & 23.296 .039 \\
2004 & 13.961 .238 & 26.118 .935 \\
2005 & 18.964 .109 & 29.168 .898 \\
2006 & 22.858 .368 & 30.258 .115 \\
2007 & 25.713 .675 & 28.277 .349 \\
\hline
\end{tabular}

(1) Faturamento informado pela Suframa em dólar pela cotação venda PTAX médio mensal

(2) Faturamento em US\$ mil de 31.12.2007, calculado pelo faturamento informado pela Suframa (1) multiplicado pela cotação do dólar PTAX venda médio anual, corrigido pelo IGPM e dividido pelo dólar PTAX venda de 31.12.2007.

Fonte: Suframa

O Gráfico 1 mostra a evolução do faturamento das empresas industriais instaladas na Zona Franca de Manaus para o período de 2003 a 2007, no qual se observa que o ano de 2006 foi o responsável pelo seu maior faturamento, no valor de US\$ 30,258 bilhões.

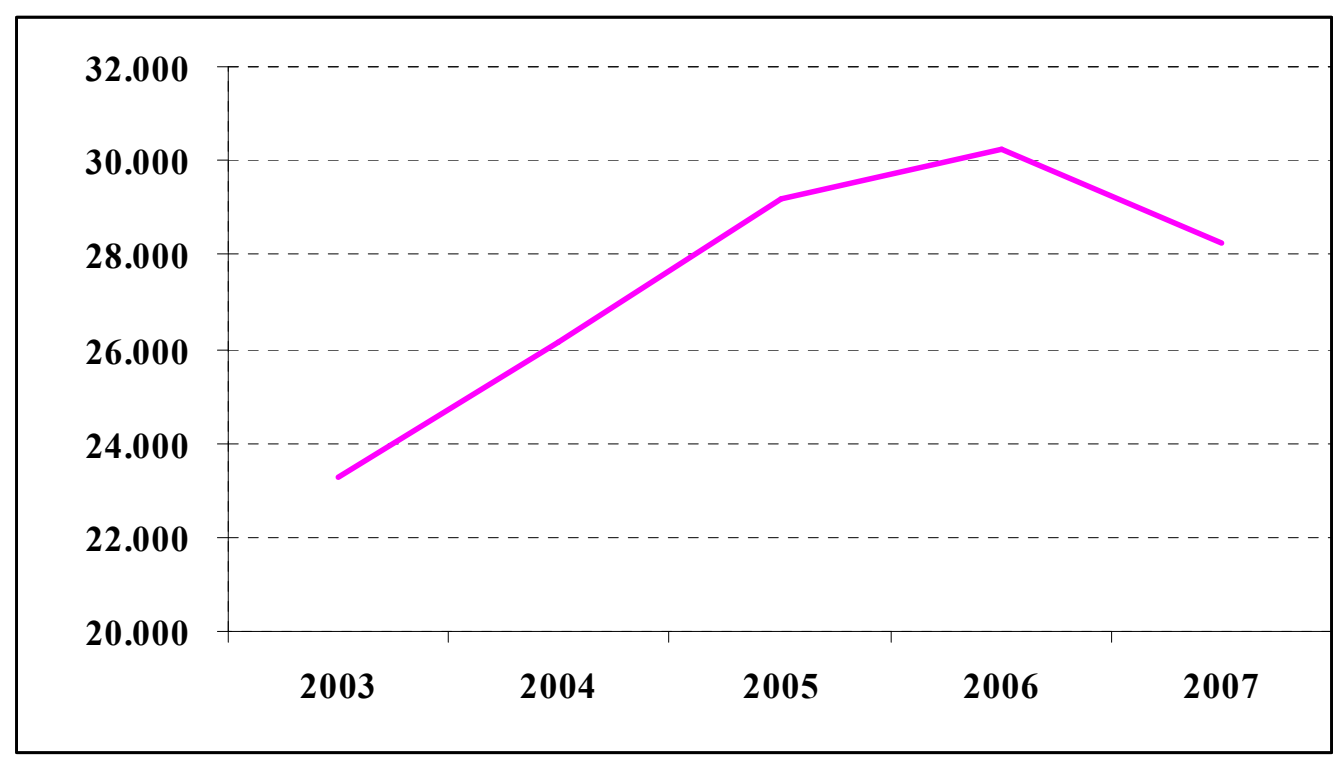

Gráfico 1 - Evolução do faturamento das empresas instaladas na Zona Franca de Manaus 2003 - 2007 (Valores em US\$ milhões)

Para o mesmo período, a Tabela 2 apresenta a criação de empregos diretos (mão de obra direta) pelas empresas industriais instaladas na Zona Franca de Manaus, sem considerar a mão de obra terceirizada e temporária. Note-se que nos anos de 2006 e 2007 há uma estabilização em torno de 89 mil postos de empregos diretos e aproximadamente 356.000 empregos 
indiretos, numa proporção de média aproximada de 4 postos indiretos para cada um direto criado.

\begin{tabular}{c|c|c}
\multicolumn{3}{c}{ Tabela 2 - Criação de empregos pela Zona Franca de Manaus - 2003 - 2007 } \\
\hline Anos & $\mathbf{N}^{\mathbf{0}}$ Empregos Diretos ${ }^{(\mathbf{1})}$ & $\mathbf{N}^{\mathbf{0}}$ Empregos Indiretos \\
\hline 2003 & 57.523 & 230.000 \\
2004 & 69.977 & 280.000 \\
2005 & 80.997 & 324.000 \\
2006 & 88.795 & 355.000 \\
2007 & 88.825 & 356.000 \\
\hline
\end{tabular}

(1) Exceto mão de obra terceirizada e temporária

Fonte: Suframa

A Tabela 3 mostra o volume de exportações e de importações realizadas pelas indústrias instaladas na Zona Franca de Manaus e o respectivo saldo da balança comercial. Deve-se registrar o aspecto negativo do saldo da balança comercial, embora mais à frente esse aspecto seja discutido e contra-argumentado em função da finalidade com a qual foi criado o modelo industrial Zona Franca de Manaus, uma vez ter sido elaborado como polo industrial para a substituição de importações e não como polo industrial exportador.

Tabela 3 - Balança comercial da Zona Franca de Manaus - 2003-2007

\begin{tabular}{l|r|r|r}
\hline \multirow{2}{*}{ Anos } & \multicolumn{3}{|c}{ Valores - US\$ 1 000 FOB } \\
\cline { 2 - 4 } & Exportações & Importações & Saldo \\
\hline 2003 & 1.301 .078 & 3.456 .402 & -2.155 .324 \\
2004 & 1.160 .281 & 4.333 .665 & -3.173 .385 \\
2005 & 2.150 .326 & 5.219 .334 & -3.069 .008 \\
2006 & 1.533 .737 & 6.258 .390 & -4.724 .652 \\
2007 & 1.107 .107 & 6.840 .059 & -5.732 .953 \\
\hline
\end{tabular}

Fonte: MDIC-Secex

Ainda como forma de mostrar os dados sobre o modelo industrial Zona Franca de Manaus e situá-lo como instrumento de desenvolvimento econômico e, por si só, merecedor de estudos exploratórios que permitam um maior entendimento e acompanhamento, torna-se necessário verificar a sua participação e importância nos gastos tributários federais.

Ao analisar a Demonstração dos Gastos Tributários $2009^{3}$, encontram-se definidos como gastos tributários os gastos indiretos dos governos realizados por intermédio do sistema

\footnotetext{
${ }^{3}$ Disponível em: $<$ http://www.receita.fazenda.gov.br>. Acesso em: 15/12/2008.
} 
tributário visando a atender objetivos econômicos e sociais. Complementa ainda que "São explicitados na norma que referencia o tributo, constituindo-se uma exceção ao sistema tributário de referência, reduzindo a arrecadação potencial e, consequentemente, aumentando a disponibilidade econômica do contribuinte.”

Esses gastos tributários possuem caráter compensatório, quando o governo não atende, adequadamente, a população dos serviços de sua responsabilidade, ou têm caráter incentivador, quando o governo tem a intenção de desenvolver determinado setor ou região, como é o caso do modelo industrial Zona Franca de Manaus.

A Tabela 4 mostra a participação desses gastos tributários em relação ao PIB. Verifica-se um crescimento ao longo do tempo, representando 1,51\% do PIB em 2003 e 2,03\% em 2007.

Tabela 4 - Participação dos gastos tributários no PIB - 2003-2007 (R\$ milhões)

\begin{tabular}{l|c|c|c|c|c}
\hline \multicolumn{1}{c|}{ Modalidade } & $\mathbf{2 0 0 3}$ & $\mathbf{2 0 0 4}$ & $\mathbf{2 0 0 5}$ & $\mathbf{2 0 0 6}$ & $\mathbf{2 0 0 7}$ \\
\hline PIB a preços correntes ${ }^{(\mathbf{1})}$ & 1.699 .946 & 1.941 .498 & 2.147 .235 & 2.369 .797 & 2.597 .611 \\
Total Benefícios (2) (3) & 25.704 & 34.322 & 41.011 & 57.586 & 52.740 \\
Benefícios/PIB \% & $1,51 \%$ & $1,77 \%$ & $1,91 \%$ & $2,43 \%$ & $2,03 \%$ \\
\hline
\end{tabular}

\footnotetext{
(1) Fonte: IBGE

${ }^{(2)}$ Fonte: Receita Federal do Brasil

(3) Estimativa para 2007.
}

Com relação à importância do modelo industrial Zona Franca de Manaus, a Tabela 5, a seguir, mostra a participação, em valores absolutos, dos gastos tributários despendidos pelo governo Federal nos anos de 2003 a 2007 por modalidade de incentivo. Verifica-se que o valor de R\$ 7,481 bilhões é a parcela destinada à Zona Franca de Manaus no ano de 2007. 
Tabela 5 - Distribuição dos gastos tributários (benefícios) por modalidade de incentivo 2003-2007 (R\$ mil)

\begin{tabular}{|c|c|c|c|c|c|}
\hline Modalidade & 2003 & 2004 & 2005 & 2006 & 2007 (1) \\
\hline $\begin{array}{l}\text { Microempresas e Empresas } \\
\text { de pequeno porte - SIMPLES }\end{array}$ & 5.740 & 8.531 & 7.737 & 12.087 & 11.165 \\
\hline Zona Franca de Manaus & 4.885 & 5.698 & 7.608 & 10.490 & 7.481 \\
\hline $\begin{array}{l}\text { Entidades sem fins lucrativos } \\
\text { Isentas/Imunes }\end{array}$ & 3.742 & 3.946 & 7.559 & 6.696 & 5.775 \\
\hline Desenvolvimento Regional & 1.952 & 2.485 & 3.854 & 4.466 & 4.522 \\
\hline Outras & 9.384 & 13.662 & 14.252 & 23.847 & 23.796 \\
\hline Total & 25.704 & 34.322 & 41.011 & 57.586 & 52.740 \\
\hline
\end{tabular}

(1) Dados estimados.

Fonte: Receita Federal do Brasil

Em complemento à Tabela 5, o Gráfico 2 mostra, em termos relativos, a participação das quatro principais modalidades de incentivos fiscais nos gastos tributários do Governo Federal no período de 2003 a 2007.

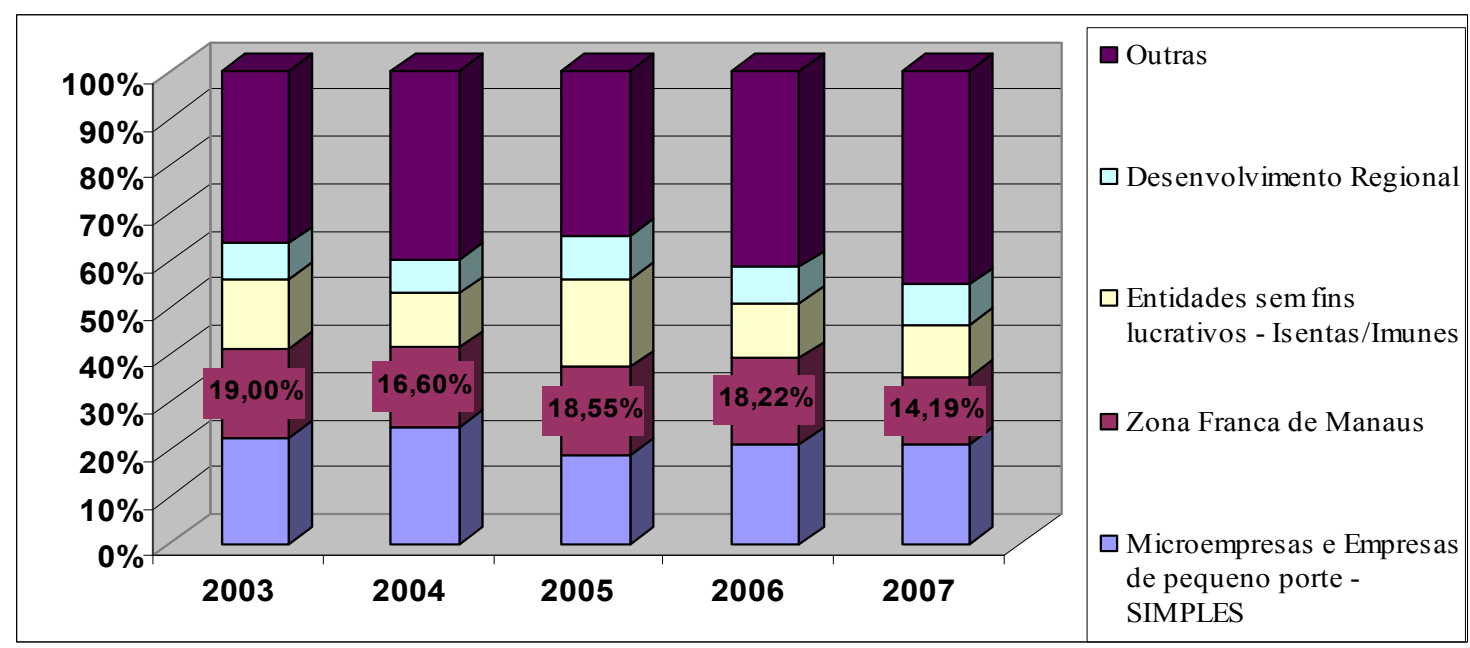

(1) Dados estimados para 2007.

Gráfico 02 - Distribuição dos gastos do Governo Federal entre as principais modalidades de incentivos fiscais - 2003 - 2007

Fonte: Receita Federal do Brasil

Observe-se que o maior percentual de recursos é destinado ao conjunto de todos os outros gastos tributários. Individualmente, apenas os incentivos destinados às Microempresas e Empresas de pequeno porte são superiores aos concedidos ao modelo industrial Zona Franca de Manaus. Embora a participação desse modelo industrial nos gastos tributários seja de 
14,19\% do total concedido pelo Governo Federal, em 2007, verifica-se que a sua participação vem sofrendo declínio, uma vez que, em 2003, essa participação representava 19,00\%.

Quando se faz uma relação das participações dos principais gastos tributários com o PIB, verifica-se que o total de incentivos fiscais federais destinados ao modelo industrial Zona Franca de Manaus vem se mantendo ao longo do período de 2003 a 2007 em 0,29\%, com exceção dos anos de 2005 e 2006, nos quais ocorreu um ligeira alta para 0,35\% e 0,44\%, respectivamente, conforme disposto na Tabela 6.

Tabela 6 - Participação dos principais gastos tributários (benefícios) no total do PIB a preços correntes $-2003-2007$

\begin{tabular}{l|c|c|c|c|c}
\hline \multicolumn{1}{c|}{ Modalidade } & $\mathbf{2 0 0 3}$ & $\mathbf{2 0 0 4}$ & $\mathbf{2 0 0 5}$ & $\mathbf{2 0 0 6}$ & $\mathbf{2 0 0 7 ( 1 )}$ \\
\hline $\begin{array}{l}\text { Microempresas e Empresas } \\
\text { de pequeno porte - SIMPLES }\end{array}$ & $0,34 \%$ & $0,44 \%$ & $0,36 \%$ & $0,51 \%$ & $0,43 \%$ \\
$\begin{array}{l}\text { Zona Franca de Manaus } \\
\text { Entidades sem fins lucrativos }\end{array}$ & $0,29 \%$ & $0,29 \%$ & $0,35 \%$ & $0,44 \%$ & $0,29 \%$ \\
$\begin{array}{l}\text { Isentas/Imunes } \\
\text { Desenvolvimento Regional }\end{array}$ & $0,22 \%$ & $0,20 \%$ & $0,35 \%$ & $0,28 \%$ & $0,22 \%$ \\
Outras & $0,55 \%$ & $0,13 \%$ & $0,18 \%$ & $0,19 \%$ & $0,17 \%$ \\
\hline Total & $\mathbf{1 , 5 1 \%}$ & $\mathbf{1 , 7 7 \%}$ & $\mathbf{1 , 9 1 \%}$ & $\mathbf{2 , 4 3 \%}$ & $\mathbf{2 , 0 3} \%$ \\
\hline
\end{tabular}

(1) Dados estimados.

Fonte: Receita Federal do Brasil

As preocupações pela manutenção do modelo industrial Zona Franca de Manaus não se restringem, apenas, ao debate dos argumentos favoráveis ou desfavoráveis com foco nos aspectos meramente quantitativos, mas a outros focos de risco, como:

- A guerra fiscal travada por outros Estados, podendo acarretar a migração de fábricas instaladas na Zona Franca de Manaus para esses Estados;

- A Reforma Tributária que, ao tratar do ICMS, prevê a mudança da cobrança da origem para o destino, o que prejudicaria um dos seus principais incentivos fiscais;

- A instituição das Zonas de Processamento de Exportação (ZPEs), aprovada por meio da Lei n. 11.508, de 20 de julho de 2007; 
- A falta de estabilização de um projeto logístico que contemple elementos que possam mitigar os custos entre o mercado produtor e o mercado consumidor, representado pelos grandes centros urbanos brasileiros.

Ao discutir o uso de incentivos fiscais como instrumento de política de desenvolvimento econômico e, ao caracterizar a Zona Franca de Manaus como um modelo industrial voltado para a promoção do desenvolvimento regional baseado nesses incentivos, defende-se a adoção da Demonstração de Valor Adicionado como instrumento para medição da riqueza criada por esse modelo industrial bem como a sua distribuição entre os agentes que ajudaram a construíla.

Martins (1993, p. 114) levanta a importância da Demonstração do Valor Adicionado ao afirmar que

[...] em alguns países, como a Índia e vários da África, exigem que qualquer empresa de fora que queira lá se instalar, mostre qual o valor adicionado que vai gerar. De nada lhes adianta quem vende muito mas comprando muito (como algumas montadoras), pouco valor agregando de riqueza nova.

Segundo Belkaoui (1998), o valor adicionado refere-se ao incremento na riqueza gerada pelo uso produtivo dos recursos das firmas antes da sua alocação entre os acionistas, credores, trabalhadores e o governo. Assim, enquanto lucro é o retorno final ganho pelos acionistas, o valor adicionado refere-se ao retorno total ganho pelos trabalhadores, pelos provedores de capital e pelo governo.

Santos (1999, p. 98) acrescenta que

\begin{abstract}
A Demonstração do Valor Adicionado - DVA, componente importantíssimo do Balanço Social, deve ser entendida como a forma mais competente criada pela contabilidade para auxiliar na medição e demonstração da capacidade de geração, bem como de distribuição, da riqueza de uma entidade.
\end{abstract}

Ribeiro e Lisboa (1999) defendem a utilização da Demonstração de Valor Adicionado (DVA) pelos governos ao afirmarem que "é uma informação de fundamental importância para a gestão econômica governamental regional." Nessa linha de raciocínio, Cunha et al. (2005, p. 10) complementam que, por meio da DVA, "torna-se possível uma melhor avaliação do conjunto de empresas formadoras de uma sociedade." 
A DVA pode ser usada não apenas como mecanismo contábil para evidenciar informações econômicas, mas para contribuir na legitimação dos projetos industriais incentivados, perante determinados agentes sociais, como instrumento que auxilie o exercício de poder disciplinar os incentivos fiscais, o que, na visão de Iudícibus e Lopes (2004, p. 59-63), pode influenciar o desenvolvimento da contabilidade.

Baseado nos dados apresentados e discutidos inicialmente e com fundamentação na teoria de comércio exterior, na teoria dos stakeholders, na literatura sobre incentivos fiscais e sobre a Demonstração de Valor Adicionado, esta tese discute o tema Zona Franca de Manaus, abordando os efeitos dos seus incentivos fiscais na criação e distribuição de riqueza.

\subsection{Problema de pesquisa}

Hamada (1974), Guinet e Kamata (1996), Baumann et al. (2004), Suzigan e Furtado (2006), dentre outros, vêm se dedicando, desde a década de 70, a estudar as Zonas de Processamento de Exportação (ZPE) e as Zonas de Livre Comércio (ZLC) e, a partir da teoria de comércio internacional, buscam respostas ao funcionamento dos modelos de desenvolvimento industriais e comerciais em operação nessas áreas.

A observação da escassez de pesquisas e estudos sobre o tema, aliada à percepção de sua importância para um melhor entendimento desse modelo industrial, bem como a utilização da Demonstração do Valor Adicionado (DVA) para a determinação da criação e distribuição de riqueza, esta pesquisa denota o seguinte problema: Quais os efeitos dos incentivos fiscais concedidos pela Zona Franca de Manaus às empresas industriais na criação e distribuição da riqueza?

Na visão de Kerlinger (1980, p. 33-35), o problema científico é uma questão que precisa de pelo menos três etapas: discussão, investigação e decisão. Acrescenta, ainda, que esses problemas devem ser testados empiricamente.

Uma vez formulado o problema e para sua melhor compreensão, esse é expandido e decomposto em cinco partes. As duas primeiras partes servem para a formação de conhecimento do funcionamento do modelo industrial Zona Franca de Manaus. Para as 
demais partes propõe-se uma resposta suposta, provável e provisória (hipótese), que seria o que se percebe mais aceitável como uma solução para o problema.

\subsubsection{Problema de pesquisa expandido}

Com a finalidade de responder à questão de pesquisa, torna-se imprescindível sua expansão, dividindo-a em questões menores que, ao serem respondidas, facilitam o prosseguimento do trabalho e contribuem para o alcance da resposta da questão proposta. São questões que permitem definir o trajeto a ser percorrido, evidenciando, ao mesmo tempo, outros aspectos cujos achados, também, facilitarão o desenvolvimento de outros trabalhos.

Essas questões de pesquisas expandidas podem ser configuradas das seguintes maneiras:

- Quais os incentivos fiscais concedidos pelo modelo industrial Zona Franca de Manaus?

- Quais as variáveis de custo utilizadas para a formação do preço de um produto industrializado na Zona Franca de Manaus?

- Como são contabilizados os incentivos fiscais, especificamente o ICMS, concedidos pelo modelo industrial Zona Franca de Manaus, pelas empresas industriais instaladas naquela região?

- Qual o valor da riqueza criada pelo modelo industrial Zona Franca de Manaus?

- Como é realizada a distribuição da riqueza criada pelo modelo industrial Zona Franca de Manaus? 


\section{$1.3 \quad$ Hipóteses}

Após enunciar o problema de pesquisa, uma proposta, provável e provisória solução é esperada. Martins e Theóphilo (2007, p. 31) expressam que:

A abordagem metodológica hipotético-dedutiva - comum nos estudos da área de humanidades pede o enunciado de hipóteses que no desenvolvimento do trabalho serão testadas e comprovadas através do suporte do referencial teórico e análises dos resultados de avaliações quantitativas e qualitativas das informações, dados e evidências conseguidas.

Popper (1972, p. 76) considera "admissíveis duas diferentes interpretações de qualquer sistema de axiomas. Os axiomas podem ser tidos (i) como convenções ou ser encarados (ii) como hipóteses empíricas ou científicas."

Na visão de Gil (2002, p. 31), a hipótese pode ser a solução de um problema, sendo caracterizada como uma “[...] expressão verbal suscetível de ser declarada verdadeira ou falsa."

Nessa mesma linha de raciocínio, Popper (1972, p. 27) afirma que um pesquisador “[...] formula enunciados ou sistemas de enunciados e verifica-os um a um" e "[...] para particularizar, ele formula hipóteses ou sistemas de teorias, e submete-os a teste, confrontando-os com a experiência, através de recursos de observação e experimentação." Logo, as hipóteses formuladas possuem as características de suposição, probabilidade e provisoriedade. De fato, elas seriam o que se percebe como mais aceitável como solução do problema porque poderão ser confirmadas ou rejeitadas com o desenvolvimento da pesquisa.

Para Luna (1997), a formulação de hipóteses é quase inevitável para quem é estudioso da área que pesquisa. Normalmente, com base em análises do sentimento do conhecimento prévio disponível, o pesquisador acaba "apostando" naquilo que pode surgir como resultado da pesquisa. 
Ao concordar com a visão desses autores e, após verificar o problema de pesquisa, tem-se a seguinte hipótese metodológica: $:^{4,5}$

\section{Hipótese geral: Os incentivos fiscais concedidos às empresas industriais instaladas na Zona Franca de Manaus possuem efeitos negativos na criação e distribuição de riqueza.}

A confirmação ou rejeição da hipótese geral poderá ocorrer de forma mais eficiente, contundente e robusta, se forem desenvolvidas cinco outras hipóteses auxiliares que, no conjunto, serão agregadas e confrontadas com a resposta que o trabalho busca.

Sobre a construção de hipóteses auxiliares, Popper (1972, p. 87) alerta:

Com respeito às hipóteses auxiliares, propomos assentar a regra de que somente serão aceitas aquelas cuja introdução não reduza o grau de falseabilidade ou testabilidade do sistema em causa, mas que, ao contrário, o eleve.

Popper (1972, p. 300) classifica a regra por ele proposta como "princípio da parcimônia no uso de hipóteses", segundo a qual as hipóteses auxiliares devem ser usadas tão parcimoniosamente quanto possível. Ele acrescenta:

\footnotetext{
Não estou interessado apenas em manter reduzido o número de nossos enunciados; estou interessado em sua simplicidade, no sentido de alta testabilidade. Esse interesse é que leva, por um lado, à minha regra de que as hipóteses auxiliares devem ser usadas tão parcimoniosamente quanto possível e, por outro lado, à minha exigência de que o número de axiomas - de nossas hipóteses fundamentais - seja pequeno.
}

\footnotetext{
${ }^{4}$ Segundo Kerlinger (1980), "Hipóteses metodológicas são enunciados conjeturais de relações e são essas conjecturas que são testadas na pesquisa, ou seja, são sentenças declarativas e enunciados de relações, e, como os problemas, devem implicar o teste das relações enunciadas.”

${ }^{5}$ Segundo Pindyck e Rubinfeld (2004), “As hipóteses estatísticas são afirmações sobre os valores de parâmetros populacionais a serem testados estatisticamente, e, geralmente, são escritos da forma $\mathrm{H}_{0}$, para a hipótese nula, e $\mathrm{H}_{1}$, para a hipótese alternativa à hipótese nula. No caso deste trabalho, resolveu-se escrever "hipótese metodológica" em relação ao enunciado conjectural para deixar bem clara essa diferença conceitual e técnica existente entre esses dois tipos de hipóteses."
} 
Diante dessa contextualização sobre a construção de hipóteses, foram elaboradas as seguintes hipóteses auxiliares:

Hipótese auxiliar 1: As empresas industriais instaladas na Zona Franca de Manaus, beneficiadas com incentivos fiscais, que publicam as demonstrações contábeis, contabilizam os incentivos fiscais de maneira incorreta.

A hipótese auxiliar 1 foi estruturada para testar as formas de contabilização dos incentivos fiscais, especificamente o ICMS, pelas empresas industriais instaladas na Zona Franca de Manaus. $\mathrm{O}$ aspecto dessa contabilização afetará a forma de criação e distribuição de riqueza pelo modelo industrial Zona Franca de Manaus e contribuirá para a resposta dos efeitos dos incentivos fiscais concedidos por esse modelo na criação e distribuição de riqueza.

\section{Hipótese auxiliar 2: As empresas industriais instaladas na Zona Franca de Manaus, beneficiadas com incentivos fiscais, que elaboram ou publicam a Demonstração de Valor Adicionado, criam mais riqueza do que as empresas industriais do mesmo setor ou similares instaladas em outras regiões do país.}

A hipótese auxiliar 2 tem como propósito mensurar a criação de riqueza pelas empresas industriais instaladas na Zona Franca de Manaus e testá-la em comparação à criação de riqueza por outras empresas industriais do mesmo setor ou similares instaladas fora da Zona Franca de Manaus.

Como a segunda parte da hipótese geral de pesquisa diz respeito à distribuição de riqueza, optou-se por estudar essa distribuição para três dos principais agentes destinatários dessa riqueza: pessoal, governos e proprietários, embora se admita a premissa preliminar de que a parte interessada "governos" recebe uma menor parcela de riqueza por tratar-se de um modelo industrial incentivado, com uma carga tributária menor do que outras empresas industriais do mesmo setor ou similares instaladas em outras regiões do país e que não são incentivadas. Ao mesmo tempo, foi deixado ao largo da pesquisa o estudo do valor da riqueza distribuída à sociedade por meio de juros e aluguéis por considerar de valor pouco representativo no contexto. 
Além das hipóteses auxiliares 1 e 2 já apresentadas, foram estruturadas outras três hipóteses auxiliares para testar a distribuição de riqueza. A primeira dessas três, com relação à parcela da riqueza destinada aos empregados, foi apresentada da seguinte forma:

Hipótese auxiliar 3: As empresas industriais instaladas na Zona Franca de Manaus, beneficiadas com incentivos fiscais, que elaboram ou publicam a Demonstração de Valor Adicionado, distribuem uma parcela maior da riqueza aos empregados do que as empresas industriais do mesmo setor ou similares instaladas em outras regiões do país.

A hipótese auxiliar seguinte foi apresentada para testar a distribuição de riqueza da parcela destinada aos governos por meio da arrecadação de tributos.

Hipótese auxiliar 4: As empresas industriais instaladas na Zona Franca de Manaus, beneficiadas com incentivos fiscais, que elaboram ou publicam a Demonstração de Valor Adicionado, distribuem uma parcela menor da riqueza aos governos do que as empresas industriais do mesmo setor ou similares instaladas em outras regiões do país.

Por fim, foi apresentada a hipótese de pesquisa auxiliar para testar a distribuição de riqueza da parcela destinada aos proprietários do capital.

Hipótese auxiliar 5: As empresas industriais instaladas na Zona Franca de Manaus, beneficiadas com incentivos fiscais, que elaboram ou publicam a Demonstração de Valor Adicionado, distribuem uma parcela maior da riqueza aos proprietários do que as empresas industriais do mesmo setor ou similares instaladas em outras regiões do país.

Ao final do trabalho, deve-se atentar para o conselho de Popper (1972, p. 275) quando alerta que [...] "cabe-nos tentar averiguar até que ponto a hipótese mostrou-se capaz de manter-se incólume, resistindo aos testes a que foi submetida." 
Ao testar as cinco hipóteses auxiliares, será testada a hipótese geral e com isso espera-se responder ao problema de pesquisa de forma satisfatória e robusta.

Uma vez caracterizada a situação-problema, definida a questão de pesquisa e estabelecida a hipótese metodológica, além da formulação das hipóteses auxiliares, podem-se enunciar os objetivos da pesquisa com a precisão e a concisão indispensáveis para o alcance do pesquisador. (MARTINS, 2002, p. 32).

\subsection{Objetivos}

Após a definição da questão de pesquisa e haver construído a hipótese a ser testada, apresentam-se, nesse tópico, os objetivos da presente pesquisa. De acordo com Gil (2002, p. 111):

Os objetivos gerais são pontos de partida, indicam uma direção a seguir, mas, na maioria dos casos, não possibilitam que se parta para a investigação. Logo, precisam ser redefinidos, esclarecidos, delimitados. Daí surgem os objetivos específicos da pesquisa.

Martins (2002, p. 32) complementa que "O fato de caracterizar um objetivo geral e outros específicos distinguirá as demais ações do estudo.”

Este trabalho apresenta, inicialmente, o Objetivo Geral, que se caracteriza como uma visão global e abrangente sobre o tema. A seguir, delineia os Objetivos Específicos, com o intuito de buscar uma melhor compreensão sobre as características detalhadas e mais específicas do Objetivo Geral.

\subsubsection{Objetivo geral}

De acordo com Martins (2002, p. 32), os objetivos, vagamente enunciados, não serão atingidos. Ele enfatiza que, nessa fase, o pesquisador buscará a resposta à questão "Para que fazer?". Para isso, pode-se fixar um objetivo geral e enunciar outros objetivos específicos. Ao mesmo tempo, ele orienta que:

À medida que a situação-problema estiver bem caracterizada e a questão de pesquisa criteriosamente definida, podem-se enunciar os objetivos da pesquisa com precisão e concisão indispensáveis ao seu alcance. 
Dessa forma, o objetivo geral desta pesquisa é:

\section{Avaliar a criação e a distribuição da riqueza gerada pelo modelo industrial Zona Franca de Manaus e confrontá-las com empresas do mesmo setor ou similares localizadas em outras regiões do país.}

\subsubsection{Objetivos específicos}

Para Martins, (2002, p. 32), o procedimento de fixação de objetivos específicos balizará todas as demais ações, possibilitando que o pesquisador corra um risco menor de fugas e desvios de rotas em sua pesquisa.

Com a finalidade de alcançar o objetivo principal, o estudo apresenta os seguintes objetivos específicos:

- Analisar as variáveis de custos que permitam a formação do preço de um produto industrial fabricado com os incentivos da Zona Franca de Manaus.

- Identificar as formas de contabilização dos incentivos fiscais, especialmente o ICMS, por parte das empresas industriais instaladas na Zona Franca de Manaus.

- Mensurar a criação de riqueza pelas empresas industriais beneficiárias de incentivos fiscais instaladas na Zona Franca de Manaus.

- Mensurar a distribuição de riqueza pelas empresas industriais beneficiárias de incentivos fiscais instaladas na Zona Franca de Manaus.

- Analisar o efeito dos incentivos fiscais sobre a criação e a distribuição de riqueza do modelo industrial Zona Franca de Manaus.

- Comparar a criação e a distribuição de riqueza gerada pelas empresas industriais instaladas na Zona Franca de Manaus com setores e empresas industriais instalados fora da Zona Franca de Manaus. 


\subsection{Contribuições esperadas e justificativas}

Uma primeira contribuição esperada que este trabalho pode proporcionar é a apresentação de um referencial teórico sobre os modelos Zonas de Livre Comércio e Zonas de Processamento de Exportação, temas esses pouco explorados na literatura nacional. Como complemento, apresentar uma discussão técnica sobre a Zona Franca de Manaus e sua inserção como uma Zona de Livre Comércio especial baseada em incentivos fiscais e sua caracterização como um modelo industrial de política pública de desenvolvimento econômico regional.

Outra contribuição esperada é suscitar o debate sobre os questionamentos feitos pela oportunidade, viabilidade, importância e avaliação dos incentivos fiscais concedidos como instrumento de desenvolvimento econômico. Com isso, suscitar uma definição de modelo de concessão de financiamentos públicos de acordo com o nível de subsídios governamentais, levando-se em conta fatores como contribuição da empresa à sociedade por meio de recolhimentos de tributos, nível de utilização de mão de obra, contribuição da empresa/modelo industrial para a geração de riqueza na cidade, Estado e região geográfica.

O presente trabalho pode, também, contribuir para a discussão de um novo modelo que analise a captação de novas empresas e novos negócios que possam agregar tecnologia e capital por meio de fixação de grau de benefícios fiscais a serem concedidos às empresas ou aos setores em que atuam e acesso ao mercado interno ou externo, de acordo com o nível de criação de riqueza.

A importância deste trabalho para a Contabilidade pauta-se na utilização de dados contábeis extraídos da Demonstração de Valor Adicionado (DVA) para identificar as formas de contabilização dos incentivos fiscais, especificamente o ICMS, concedidos pelo modelo industrial Zona Franca de Manaus e analisar os efeitos dos incentivos fiscais na criação e na distribuição de riqueza, áreas, muitas vezes, discutidas apenas pela Economia.

Complementarmente, este estudo propicia contribuições para o meio acadêmico e para a sociedade como um todo, uma vez que fornece conceitos para um melhor entendimento técnico do modelo industrial e mostra como os incentivos fiscais impactam na composição do custo do produto fabricado na Zona Franca de Manaus e, em decorrência, possibilitam um preço de venda ao consumidor menor, uma vez que permite aos usuários externos conhecerem 
as variáveis que influenciam o custo do produto bem como os efeitos dos incentivos fiscais na formação do preço.

Embora sejam necessárias padronizações e conciliações de alguns procedimentos metodológicos, a utilização da Demonstração de Valor Adicionado pela facilidade de cálculo, pela facilidade de análise e pela facilidade de obtenção de dados, permite como proxy, por meio da soma dos valores adicionados produzidos por todos os agentes econômicos, a sua aplicação para cálculos do Produto Interno Bruto.

Com isso, poderia ser realizada uma análise setorial, na qual fossem verificadas as contribuições da empresa e do setor para a formação da riqueza local, regional e nacional; a percepção do nível de contribuição da empresa e do setor para a formação de riqueza local, regional e nacional; a participação da empresa e do setor no montante dos tributos recolhidos. Logo, por meio dessas análises, poderia determinar a viabilidade de projetos econômicos de investimentos, a criação de um indicador que possa ser utilizado pelas instituições públicas na concessão de incentivos voltados ao desenvolvimento e financiamentos e a determinação do nível de subsídios a serem concedidos aos projetos a serem instalados em determinada região.

Espera-se, ao final desta pesquisa, mostrar, além dos resultados alcançados, uma discussão mais aprofundada das vantagens e utilização da Demonstração de Valor Adicionado (DVA) como um instrumento importante para a formulação de políticas públicas e de concessão de incentivos e subsídios fiscais.

Por fim, espera-se que o presente trabalho possa contribuir com os órgãos operadores das normas tributárias no tocante à formulação de políticas de incentivos físcais bem como para as empresas com relação à formulação de planejamento tributário, especialmente na tomada de decisões estratégicas para implantação, ampliação e relocalização de novos projetos de investimentos.

\subsection{Delimitação e limitação da pesquisa}

Diante da escassez de literatura sobre o tema, da diversidade de legislações federal, estaduais e municipais e da abrangência do tema, algumas delimitações se fazem necessárias. Nesse 
aspecto, as delimitações devem ser entendidas como aspectos não cobertos e pesquisados pelo presente trabalho.

Primeiramente, deve-se ressaltar que o presente trabalho se aplica apenas às empresas industriais instaladas na Zona Franca de Manaus, beneficiárias dos incentivos fiscais pertinentes àquele modelo industrial. Acrescente-se o fato de que a pesquisa foi realizada a partir de duas amostras: a primeira, com as empresas que publicam as demonstrações contábeis, destinada à identificação e análise das formas de contabilização dos incentivos fiscais, especificamente o ICMS; a segunda amostra, menor do que a primeira, foi formada apenas com as empresas que publicaram ou elaboraram a Demonstração de Valor Adicionado (DVA).

Outra delimitação muito importante diz respeito ao período pesquisado. Como ponto de corte, partiu-se do ano de 2003 por supor que, de maneira não aleatória, cinco períodos seriam suficientes para a pesquisa, terminando o período pesquisado em 2007. A escolha desse último período coincide com a voluntariedade na elaboração da Demonstração de Valor Adicionado (DVA), uma vez que, a partir de 2008, em decorrência da vigência da Lei n. 11.638, de 28 de dezembro de 2007, essa demonstração tornou-se obrigatória para as companhias abertas.

Ao mesmo tempo, alerta-se para o fato de que a maioria das grandes empresas industriais instaladas na Zona Franca de Manaus são empresas filiais de indústrias transnacionais e não estão obrigadas à publicação de demonstrações contábeis e financeiras. São empresas fechadas, pertencentes a setores com pouco grau de transparência, o que dificulta, sobremaneira, a obtenção de dados.

Acrescente-se como outra importante delimitação a utilização de técnicas estatísticas, regressão linear e teste de média, que, embora forneçam uma resposta provável para a população a partir da amostra, permanece uma parcela sem explicação. 


\subsection{Estrutura do trabalho}

O presente trabalho está estruturado a partir desse primeiro capítulo no qual são apresentadas uma contextualização do tema pesquisado e seus pressupostos, a problemática, a hipótese geral e as hipóteses auxiliares, os objetivos geral e específicos, bem como as contribuições esperadas, justificativas e, por fim, as limitações e delimitações.

O segundo capítulo diz respeito à revisão da literatura. Demonstra-se a fundamentação teórica a respeito dos conceitos diretamente relacionados ao tema e àqueles que, embora não intrinsecamente relacionados, possibilitem a facilidade do seu entendimento uma vez que formam a estrutura molecular conceitual ao seu redor. Nessa parte do trabalho, apresentam-se os conceitos fundamentais sobre políticas de desenvolvimento econômico, visitando os conceitos de política industrial, subsídios e incentivos fiscais e zona de livre comércio; teoria sobre comércio exterior; teoria dos stakeholders ${ }^{6,7}$ e sobre Demonstração de Valor Adicionado (DVA).

Em seguida, no terceiro capítulo, é feita uma descrição do modelo industrial Zona Franca de Manaus, sua conceituação e um breve histórico. Mostram-se os principais incentivos fiscais envolvidos, exemplos de formação de preço de um produto fabricado naquela área industrial e a forma de contabilização dos incentivos físcais concedidos.

No quarto capítulo, são apresentados os procedimentos metodológicos abordados no trabalho com a tipificação da pesquisa, os artefatos utilizados e a caracterização da amostra e os períodos utilizados.

O quinto capítulo dedica-se à parte de análise dos dados, o que envolve atingir os objetivos propostos e responder à questão de pesquisa. Nesse capítulo, apresentam-se as estatísticas descritivas e os modelos estatísticos de regressão linear e testes de médias realizados para testar as hipóteses auxiliares e sua confrontação com a hipótese geral.

\footnotetext{
${ }^{6}$ Todas as traduções deste trabalho são do autor e não literais.

${ }^{7}$ Termo em inglês, aqui traduzido como partes interessadas.
} 
O último capítulo abrange as conclusões e as considerações finais. Encerra-se o trabalho com as referências, um glossário sobre os termos utilizados no seu decorrer, a fim de serem esclarecidos alguns conceitos utilizados, e os apêndices. 



\section{PLATAFORMA TEÓRICA}

Esse capítulo destina-se a discutir os principais conceitos que fazem parte do arcabouço teórico deste trabalho. Inicialmente, propõe-se a apresentar um breve relato sobre políticas de desenvolvimento econômico e política industrial para contextualizar os incentivos fiscais como parte integrante dessas políticas. Em seguida, são discutidas abordagens da teoria sobre comércio exterior, especialmente com relação aos conceitos e importâncias das Zonas Econômicas Especiais, para fazer um elo entre os incentivos fiscais e essas Zonas de Livre Comércio, nas quais a Zona Franca de Manaus está contida. Por fim, discute-se a teoria dos stakeholders para inserir em seu contexto os conceitos e a importância da Demonstração de Valor Adicionado.

\subsection{Políticas de desenvolvimento econômico}

O tema crescimento econômico surge com vitalidade a partir dos estudos de Adam Smith. Ele buscou identificar e mensurar os fatores da formação da riqueza de uma nação, explicando a forma como o mercado opera e qual a importância do aumento do tamanho dos mercados para reduzir os custos médios, por meio do efeito escala, e permitir uma produção lucrativa.

Com a expansão dos mercados, haveria o aumento da renda e do emprego. Por outro lado, o desenvolvimento econômico ocorre com o aumento da produtividade, decorrente do aumento da proporção dos trabalhadores produtivos e improdutivos; pela diminuição do desemprego e elevação da renda média da população.

Gremaud et al. (2007, p. 58) corroboram o conceito de desenvolvimento econômico, apresentando-o "como aquele associado às condições de vida da população ou à qualidade de vida dos residentes do país." Eles alertam que o conceito de desenvolvimento envolve aspectos que vão além da ideia de crescimento, referindo-se aos conceitos de equidade, sustentabilidade e participação. (Ibid., p. 77).

Por equidade, eles se valem das definições utilizadas no relatório sobre o desenvolvimento brasileiro realizado pelo IPEA e pelas Nações Unidas, que conclui que a equidade é "um componente essencial do desenvolvimento humano: as pessoas devem ter acesso a iguais 
oportunidades, de modo que possam participar e se beneficiar dos frutos e das oportunidades criadas pelo processo de crescimento econômico." Sobre o conceito de desenvolvimento sustentado, eles entendem ser aquele que, ao atender às necessidades do momento presente, não impõe um limite ao atendimento das necessidades futuras. Por fim, como desenvolvimento participativo, eles o caracterizam como aquele que é definido e guiado por meio de decisões que agreguem toda a comunidade envolvida. (Ibid., p.77).

Segundo Souza (2008, p. 5), não existe uma definição universalmente aceita de desenvolvimento. Ele apresenta a versão que considera o desenvolvimento como função do crescimento quantitativo do produto e a que considera o desenvolvimento como resultante de mudanças estruturais na qualidade de vida das pessoas. Embora ele confronte essas duas correntes que tratam sobre o conceito de crescimento e desenvolvimento econômico, observase sua opção pela segunda corrente ao afirmar que [...] "encara o crescimento econômico como uma simples variação quantitativa do produto, enquanto o desenvolvimento envolve mudanças qualitativas no modo de vida das pessoas, das instituições e das estruturas produtivas." Ele conclui que o desenvolvimento caracteriza-se pela transformação de uma economia, decorrente da sua modernização e eficiência, aliada à melhoria do nível de vida do conjunto da sociedade.

Lastres (1997, p. 44) destaca como política de desenvolvimento econômico as políticas industriais regionais ao afirmar que "Essas políticas buscam encorajar e facilitar a conversão industrial e a diversificação dos recursos locais de capital e trabalho, [...] e promover um processo de desenvolvimento passível de auto-sustentação em regiões subdesenvolvidas."

Por sua vez, Cassiolato (1999, p. 82) diz que as políticas de desenvolvimento econômico devem considerar outros parâmetros importantes como a questão do emprego, o balanço comercial e o aumento dos retornos de processos tecnológicos interativos. Acrescenta, ainda, que um conceito-chave a ser considerado é o reconhecimento de que as políticas comerciais, de investimento e tecnológicas devem ser consideradas de maneira holística, conjunta e não separadamente.

Com o objetivo de contextualizar as Zonas de Processamento de Exportação e as Zonas de Livre Comércio, nas quais a Zona Franca de Manaus se insere de uma forma macro, como estratégia de política de desenvolvimento econômico e, por sua vez como política industrial, 
torna-se necessária uma abordagem conceitual sobre essas áreas de produção. Jenkins e Jenkins (2007, p. 1-3) mostram que

As Zonas de Processamento de Exportação e as Zonas de Livre Comércio são criadas pelos governos para promover estratégias orientadas à exportação com o objetivo de alcançar crescimento e prosperidade. O propósito das Zonas de Livre Comércio na maioria dos países é fornecer um ambiente mais apropriado para produção destinada à exportação até que a economia como um todo se reestruture de forma a encorajar essa produção numa escala maior.

Esses autores acrescentam que alguns países têm obtido sucesso em alcançar esse objetivo e foram capazes de reformar suas economias enquanto outros ainda se encontram em um estágio inicial em que muitas mudanças precisam ser feitas em termos de aduana e administração comercial para incrementar uma política geral e um ambiente administrativo para o comércio internacional.

Para o propósito do presente trabalho, adota-se o conceito de política de desenvolvimento econômico como planos, estratégias e operações econômicas que buscam o desenvolvimento pela transformação de uma economia, decorrente da sua modernização e eficiência, aliada à melhoria do nível de vida de toda a sociedade.

\subsubsection{Política industrial}

A implantação, confiabilidade e sucesso de um uma política industrial passam pelo grau de determinação que os entes governamentais - federal, estaduais e municipais - desejam para o desenvolvimento econômico da sociedade. Para isso, esses agentes precisam adotar medidas que vão desde a infraestrutura até a concessão de incentivos fiscais, de crédito, de apoio ao investimento, de apoio logístico, de fomento à pesquisa e desenvolvimento e, por fim, à exportação.

Rodrik (2004, p.19-21), ao escrever sobre a construção de uma política industrial para o século vinte um, discute os arranjos institucionais para uma política industrial e, dentro desse contexto, classifica como três os elementos de uma arquitetura institucional:

- A liderança política no topo

O sucesso da política industrial depende muitas vezes da presença de apoio político de alto nível. Prudência fiscal tem um campeão na pessoa de um ministro das Finanças e dinheiro tem um campeão na pessoa de um presidente de banco central. A reestruturação econômica também 
precisa de um advogado político que tenha o ouvido do presidente ou primeiro-ministro e que possa contar da mesma maneira com os outros membros do gabinete econômico.

- Coordenação e deliberação do conselho

Embora as escolhas institucionais naturalmente divirjam de configuração para configuração, dependendo das condições iniciais, há uma necessidade genérica por conselhos de coordenação ou deliberação, dentro dos quais a troca de informações e de aprendizagem social possam ter lugar.

- Mecanismos de transparência e de responsabilidade

Políticas industriais precisam ser vistas pela sociedade em geral como parte de uma estratégia de crescimento que está orientada para a expansão de oportunidades para todos, e não como brindes para setores já privilegiados da economia.

Ao analisar a literatura sobre o tema, verifica-se que o conceito de política industrial varia de acordo com o pensamento dos autores. A busca por uma explicação teórica sobre o que é uma política industrial permanece no âmbito da especulação. Isso se comprova pelas inúmeras formas de utilização desse termo, que vão desde o seu emprego para definir as ações estimulantes de programas de substituição de importações até as ações de investimentos de recursos públicos dos bancos de desenvolvimento em investimentos privados.

Contrapondo-se a essa ideia, Baumann et al. (2004, p. 97) afirmam:

A idéia básica associada a um processo de substituição de importações é a de promoção - no mercado interno de uma economia - da capacidade de oferta de itens anteriormente conseguidos por meio do comércio externo. Dessa maneira, a produção nacional substitui a oferta de alguns produtos importados.

Entretanto, em uma definição ampla sobre o que seria uma política industrial, alguns elementos devem constar, dentre os quais:

- $\quad$ Planejamento e criação;

- $\quad$ Desenvolvimento e implementação;

- Coordenação, acompanhamento e controle;

- $\quad$ Ferramentas estratégicas;

- Ampliação, desenvolvimento e aperfeiçoamento da capacidade produtiva e comercial do setor industrial e

- Desenvolvimento e garantia de condições de competitividade nos mercados internos e externos. 
Rodrik (2004, p. 21-25) elenca os dez princípios para a concepção de uma política industrial, a saber:

1. Os incentivos devem ser concedidos apenas para novas atividades;

2. Deve haver indicadores ou critérios claros de sucesso e fracasso;

3. Deve haver uma cláusula built-in sunset; ${ }^{8}$

4. O apoio público deve almejar atividades, não setores;

5. Atividades que são subsidiadas devem ter o potencial claro de gerar repercussões e demonstração dos efeitos;

6. A autoridade para realizar as políticas industriais, deve ser atribuída a agências com comprovada competência;

7. As agências executoras devem ser acompanhadas de perto por um principal com uma clara aposta nos resultados e que tenha autoridade política no mais alto nível;

8. As agências executoras de promoção devem manter canais de comunicação com o setor privado;

9. De uma maneira otimizada, erros que resultem em escolher os perdedores ocorrerão e

10. A promoção de atividades precisa ter capacidade para se renovar, a fim de que a descoberta se torne um ciclo contínuo.

Suzigan e Furtado (2006, p. 165) alertam que:

É amplamente reconhecido o fato de que a política macroeconômica pode ser antagônica a uma estratégia de desenvolvimento baseada em política industrial. Isto decorre da administração dos dois preços básicos da economia - juros e câmbio - e do nível e estrutura de tributação. Mas é menos reconhecido que a política industrial também pode afetar objetivos macroeconômicos, por exemplo, por meio de aumentos de produtividade. O que importa é que a política industrial não seja inviabilizada por políticas macroeconômicas muito restritivas ou muito instáveis.

É de ressaltar que a formulação de uma política industrial deve ser estruturada visando ao conjunto dos setores industriais, mas, vez por outra, devem-se enfatizar programas que contribuam para impulsionar setores industriais que são importantes para a economia e estratégicos para o desenvolvimento do parque industrial de um país. Para o alcance desse objetivo, o desenvolvimento e a implementação de uma política industrial devem ser articulados entre os entes públicos e os agentes privados.

\footnotetext{
${ }^{8}$ Cláusula com período de adaptação para entrada em vigor de uma determinada condição ou norma.
} 
Dentro desse contexto, Suzigan e Furtado (2006, p. 166) mostram que:

O sucesso de uma política industrial como estratégia de desenvolvimento centrada na inovação depende também da difícil articulação de instrumentos, normas e regulamentação. São esses mecanismos de implementação da política industrial que criam o padrão de sinais econômicos, regulam os incentivos e restrições à inovação e tornam possível sintonizar as ações das empresas, na sua busca por lucratividade, aos objetivos da política industrial, que procura promover o desenvolvimento e a competitividade.

Contudo, qualquer caracterização que deva ser dada ao conceito do termo política industrial, importa objetivar-se sempre o efeito que as ações possam causar na sociedade e que sua aplicação possa propiciar retornos para a economia.

O desenvolvimento econômico de uma nação pode ser obtido por meio de diversas estratégias e modelos. Logo, uma das formas de promover o desenvolvimento econômico é por meio de uma política industrial. Dentro desse contexto e desde que atendam aos requisitos básicos que uma política industrial deva conter, encontra-se a instalação de parques industriais com o objetivo de substituição de importações.

Baumann et al. (2004, p. 97) acrescentam que "Essa estratégia de promoção de industrialização tem em geral um forte componente de indução e, portanto, de dependência de recursos públicos, uma vez que está freqüentemente associada à provisão de incentivos fiscais e creditícios."

Krueger (1997), ao tratar do modelo de industrialização para substituição de importações, afirma que a industrialização era necessária para o desenvolvimento e que o livre comércio deixaria subdesenvolvidos os países especializados na produção de produtos primários. Ele acrescenta que, numa fase inicial, as políticas de substituição de importação eram estratégias para a industrialização e desenvolvimento desses países e que essas políticas eram tão amplamente aceitas que algumas exceções foram incorporadas aos artigos do GATT. Além disso, "Em alguns países e indústrias, o regime comercial foi usado como principal instrumento de política para fornecer incentivos para o investimento e produção de substituição de importação por empresas privadas." (Ibid., p. 14). ${ }^{9}$

\footnotetext{
9 "In some countries and industries, the trade regime was used as the key policy instrument to provide incentives for import-substituting investment and production by private firms."
} 
Krueger (1997, p.46) ressalta que os níveis de proteção comercial defendidos pelos países em desenvolvimento, pela alegação do fato de existência de uma indústria ainda em fase embrionária, ao adotar uma política industrial de substituição de importações poderiam ser criados empregos e renda, acrescentando-se o desenvolvimento tecnológico agregado pelo processo industrial. Entretanto, ele conclui que

\begin{abstract}
No caso de política e desenvolvimento comercial, as manifestações em que houve respostas aos incentivos e em que os países em desenvolvimento poderiam aumentar suas receitas de exportação [...], foram claramente cruciais para uma melhor compreensão das relações de comércio para o desenvolvimento. ${ }^{10}$
\end{abstract}

É nesse aspecto que deve ser contextualizada a Zona Franca de Manaus como uma política industrial pertencente ao contexto macro das políticas de desenvolvimento econômico. Caracteriza-se como um modelo industrial de política de desenvolvimento econômico, criada originalmente como um plano estratégico de geopolítica e com o objetivo primordial de substituir as importações por meio da fabricação interna de produtos e que com isso alcançasse crescimento tecnológico, econômico e prosperidade.

Sobre a constitucionalidade da Zona Franca de Manaus, Andrade (2008, p. 257) afirma que

[...] a instrumentalização de políticas de desenvolvimento em nível de constituição com o intuito de alocar recursos e dinamizar a máquina estatal para a consecução desse objetivo. Tais normas constitucionais autorizam uma ação legiferante que amplie a operacionalidade de condutas que levam ao rompimento do processo de subdesenvolvimento.

Ribeiro (2008, p. 346) complementa que uma legítima política tributária deve ser fundada em diversos fatores e não apenas baseada na arrecadação do Estado. Essa política deve atender aos ditames constitucionais, visando ao desenvolvimento econômico e social e, com isso, diminuindo o processo de subdesenvolvimento de determinadas regiões.

Logo, a adoção dessas políticas, tomadas como o conjunto de medidas de natureza econômica destinadas a romper nossas condições de subdesenvolvimento econômico e social, têm como objetivo o desenvolvimento geral da nação. Entretanto, Andrade (2008, p. 269) alerta que

\footnotetext{
10 "In the case of trade policy and development, the demonstrations that there were responses to incentives and that developing countries could expand export earnings[...], were clearly crucial to improved understanding of the relationship of trade to development."
} 
[...] como política de desenvolvimento não se reduz a incentivos fiscais, há de existir maior presença da União na região visando ampliar a eficácia das medidas até então implementadas. Falta, assim, aliar o desenvolvimento econômico o desenvolvimento humano, com intuito de levar ao contingente populacional que hoje vive na região de influência sócio-econômica da Zona Franca de Manaus melhores condições de vida.

A importância dos incentivos fiscais concedidos às empresas instaladas na Zona Franca de Manaus é defendida por Ribeiro (2008, p. 329), ao dizer que

Os incentivos fiscais concedidos na Zona Franca de Manaus, constituem primordial importância para a promoção do equilíbrio regional, incentivando o investimento e estimulando o crescimento da região amazônica. Tais incentivos, guardadas as proporções, têm demonstrado um resultado positivo, por atender a função social do tributo no âmbito da abrangência da Zona Franca de Manaus, embora tenha que alcançar outros propósitos.

A partir do conceito da função social do tributo e com a predominância do modelo do Estado Social, Ribeiro (2008) é de opinião que não se pode abrir mão do uso dos tributos como eficazes instrumentos de política e de atuação estatal, nas mais diversas áreas, sobretudo na social e na econômica. Acrescenta que "O tributo como instrumento de política econômica conjuntural e estrutural tornou-se uma ferramenta indispensável no Estado contemporâneo ao lado de outros incentivos financeiros." (Ibid., p. 336).

Diante disso, “[...] a tributação surge como alternativa do Estado para fomentar o desenvolvimento nacional, cujo conceito deve abarcar de forma especial a redução das desigualdades regionais e sociais." (ELALI, 2007, p. 41).

Assim, é de se esperar que as normas tributárias instituam e regulem, a partir do modelo Constitucional, benefícios e/ou agravamentos, visando à realização de comportamentos mais desejáveis pelos agentes econômicos. Nesse contexto, Elali (2007) conclui que os incentivos fiscais são instrumentos hábeis para servir à indução econômica nas hipóteses de benefícios que passam a ser outorgados para incentivar comportamentos específicos.

Logo, espera-se que com a aplicação do tributo como instrumento social, seja possível que o Estado possa desenvolver uma política social justa e distributiva como forma de alcançar as finalidades a que se prestou a implementar. "Assim, a função social do tributo estará em sintonia com a redução das desigualdades regionais propugnadas nos fundamentos republicanos, demonstrando a eficácia dos incentivos fiscais da Zona Franca de Manaus." (RIBEIRO, 2008, p. 347). 


\subsubsection{Conceituação e importância dos subsídios e incentivos fiscais}

Com o objetivo de melhor definir os benefícios fiscais concedidos pelo modelo industrial Zona Franca de Manaus aos estabelecimentos industriais instalados naquela região, torna-se imprescindível a separação e conceituação dos termos subsídios e incentivos fiscais. Esses conceitos revestem-se de extrema importância pelo tratamento dado à contabilização dos incentivos fiscais, especificamente o ICMS.

Não é de se esperar que os benefícios fiscais sejam determinantes por si só para as tomadas de decisões de investimento, como a implantação ou localização de empreendimentos, pelo setor privado. Essas decisões estão primeiramente relacionadas a fatores mais robustos como tamanho e disputa de mercados, expectativas de retornos, inserção em determinado mercado local, regional e nacional, dentre outros. Para Elali (2007, p. 65), “A concessão de incentivos fiscais, sob qualquer rótulo ou forma jurídica, deve ser examinada a partir dos benefícios que gera para o sistema social."

Elali (2007, p. 48) parte da premissa de que "um incentivo fiscal é a supressão e/ou a redução do ônus com o recolhimento de tributos". Ao afastar o estudo analítico de suas espécies, ele menciona os seguintes elementos relacionados às figuras dos incentivos fiscais:

\footnotetext{
i) as subvenções, que constituem um benefício de natureza financeira;

ii) os créditos presumidos, que têm natureza complexa, ora apresentando-se como subsídio, ora como subvenção, ora como mera redução da base de cálculo dos tributos;

iii) os subsídios, que podem ser estímulos de natureza fiscal ou comercial, para promover determinadas atividades econômicas por períodos transitórios;

iv) as isenções tributárias, que evitam o nascimento, por lei, da própria obrigação tributária;

v) o diferimento, que representa uma isenção condicionada.
}

Na visão de Diniz (2007, p. 296) “incentivo, incentivo fiscal, benefício fiscal e isenção não se confundem." Para ele, "incentivo é o meio pelo qual o Estado busca concretizar as finalidades da ordem econômica, disposta no art. 170 da CF, sempre em prol do bem comum mediante a vinculação do administrado a deveres e obrigações legalmente estabelecidas."

Diniz (2007, p. 271-275) traz, ainda, as seguintes definições para incentivo fiscal, benefício fiscal e isenção. Ele acrescenta que entre as diversas espécies de incentivos, localizam-se os incentivos fiscais, os quais ele define como sendo aqueles que "alcançam as obrigações tributárias ao alterar ou mutilar a regra-matriz de incidência, acarretando a redução da prestação tributária, visando ao fomento geral, regional ou setorial, em busca do bem 
comum." Benefício fiscal ele define como sendo "privilégio diretamente dirigido ao contribuinte, proveniente de norma jurídica que não exige contrapartida diretamente vinculada à promoção do bem comum." As isenções são definidas como "hipóteses em que o Estado exonera o contribuinte, total ou parcialmente, de determinada obrigação tributária, atacando a regra-matriz do tributo, sem, todavia, vinculá-lo diretamente a certa contrapartida."

Elali (2007) é de opinião que todas as figuras, meios de incentivos, não obstante possíveis diferenças em seus regimes jurídicos, são instrumentos hábeis para a intervenção estatal sobre o domínio econômico, incentivando determinados comportamentos por parte dos agentes econômicos, vinculadas, aos interesses públicos. Acrescenta que

[...] a concessão de incentivos fiscais é de indubitável relevância em termos de buscar-se o desenvolvimento econômico. Assim, é ponto pacífico que tais medidas visam ao melhoramento das condições do sistema econômico, destacando-se os seguintes objetivos dos auxílios de Estado (subvenções, subsídios, incentivos fiscais etc.): i) a redução das desigualdades regionais; ii) a promoção do emprego, "particularmente em áreas onde o desemprego é grande ou os empregos destinados a certas categorias de trabalhadores"; iii) a captação de investimentos a fim de promover a atividade econômica e empresarial do país; iv) a reestruturação de empresas de base e de determinados setores econômicos considerados prioritários; v) o fomento das exportações. (Ibid., p. 66).

Para Melo (2007, p. 140),

\begin{abstract}
Os incentivos fiscais consistem, basicamente, em espécie de renúncia de receitas públicas para o administrador público e benefícios aos administrados (contribuintes), objetivando o desenvolvimento econômico regional, o aumento do saldo da balança comercial, o desenvolvimento do parque industrial nacional, a geração de empregos, a colocação de produtos de fabricação nacional no mercado externo, dentre outros.
\end{abstract}

Pires (2007) destaca que os incentivos fiscais dividem-se em duas categorias: os que operam sobre a despesa e os que operam sobre a receita. Os primeiros permitem controle orçamentário mais eficaz, embora os últimos sejam considerados os incentivos físcais por excelência. Os incentivos fiscais concedidos com base na desoneração fiscal requerem cuidado maior na sua aplicação, devendo manter coerência com os princípios da atividade administrativa e com os princípios tributários, além de obedecer às normas constitucionais de direito financeiro, conforme preceitua a Lei Maior. (Ibid., p. 20).

Como incentivos fiscais que incidem sobre a despesa pública, Pires (2007, p. 21) divide-os em subvenções, crédito presumido e subsídios. Ao conceituar a subvenção, ele alerta que não deve ser confundida com subsídio, pois “pode-se dizer que se trata de uma doação modal cuja 
destinação é especificada pela pessoa jurídica de direito público concedente segundo sua conveniência política". Acrescenta ainda que "As subvenções também se distinguem pelas finalidades previstas na lei que as concede, podendo-se, neste caso, considerá-las como de "custeio" e de "investimento". O caráter típico de incentivo manifesta-se no primeiro tipo, verdadeira doação condicionada à realização de certa contrapartida pelo beneficiário. $\mathrm{O}$ propósito é incentivar atividade que, em condições normais, não seria empreendida.”

Por crédito presumido, Pires (2007, p. 21) diz que a sua natureza jurídica é variada, "podendo, por vezes, tratar-se de um subsídio, de uma subvenção ou de uma mera redução da base de cálculo."

Como subsídio, Pires (2007) entende tratar-se de

toda ajuda oficial do governo, seja de natureza comercial, financeira, cambial ou fiscal, com o fim de estimular a produtividade de indústrias instaladas no País. Os subsídios têm efeito equalizador de preços, de forma a corrigir distorções no mercado ou reduzir desigualdades sociais regionais, além de servir como instrumento de incentivo à exportações, sobretudo em países em desenvolvimento. (Ibid., p. 21).

No âmbito da receita pública, Pires (2007) classifica os incentivos fiscais em isenção, diferimento, remissão e anistia, com interesse para este trabalho os conceitos dos dois primeiros. Para ele, normalmente, a isenção é explicada com base em duas correntes doutrinárias:

\footnotetext{
A primeira, clássica, decorrente da interpretação literal do art. 175 do CTN, afirma que a isenção consiste na dispensa legal do pagamento do tributo, consoante os termos do artigo citado, segundo o qual a isenção é uma forma de exclusão do crédito tributário.

De acordo com a segunda, a isenção consiste em modalidade de não incidência, isto é, a lei isentiva suspende a eficácia da lei impositiva, evitando que ocorra o efeito que lhe é peculiar, qual seja, o nascimento da obrigação tributária. (Ibid., p. 22-23).
}

Quanto ao diferimento, Pires (2007, p. 23) diz que esse se verifica por meio da modificação do critério temporal do fato gerador, que se caracteriza como o instituto segundo o qual se alonga o prazo para cumprimento da obrigação. Complementa que constitui um dos instrumentos mais utilizados em matéria de incentivos fiscais, embora não possua definição expressa no nosso ordenamento jurídico e que parte da doutrina o vê como subespécie da isenção. 
Para Diniz (2007, p. 278), a interpretação dos incentivos fiscais deve se pautar em duas premissas: “i) a norma instituidora do incentivo fiscal não pode ser interpretada individualmente, em compartimentos estanques", ou seja, torna-se necessária a confrontação do objeto da interpretação com o ordenamento jurídico a todo instante e "ii) os incentivos fiscais, por visarem, sem exceção ao bem comum, o beneficiamento da coletividade deve sempre ser levado em consideração."

Nesse contexto, Rodrigues (2007, p. 300) defende os incentivos fiscais no âmbito constitucional e os relaciona com a criação e a manutenção da Zona Franca de Manaus, ao afirmar:

\footnotetext{
Uma das formas de promover o desenvolvimento de regiões menos desenvolvidas do País é, sem dúvida, a redução ou eliminação de encargos de ordem fiscal, como ocorreu em relação à criação da Zona Franca de Manaus, pela Lei n. 3.173/57, alterada pelo Decreto-Lei n. 288/67, mantida pela constituição de 1988, na forma do art. 40 do ADCT.
}

No âmbito normativo, o Pronunciamento Técnico CPC-07, que trata da Subvenção e Assistência Governamentais, cujo Termo de Aprovação se deu em 03 de outubro de 2008, apresenta os seguintes conceitos:

\footnotetext{
Subvenção governamental é uma assistência governamental geralmente na forma de contribuição de natureza pecuniária, mas não só restrita a ela, concedida a uma entidade normalmente em troca do cumprimento passado ou futuro de certas condições relacionadas às atividades operacionais da entidade. Não são subvenções governamentais aquelas que não podem ser razoavelmente quantificadas em dinheiro e as transações com o governo que não podem ser distinguidas das transações comerciais normais da entidade.

Isenção tributária é a dispensa legal do pagamento de tributo sob quaisquer formas jurídicas (isenção, imunidade, etc.). Redução, por sua vez, exclui somente parte do passivo tributário, restando ainda, parcela de imposto a pagar. A redução ou a isenção pode se processar, eventualmente, por meio de devolução do imposto recolhido mediante determinadas condições.

$[\ldots]$

A subvenção governamental é também designada por: subsídio, incentivo fiscal, doação, prêmio, etc.
}

Em 21 de novembro de 2008, por meio da Resolução n. 1.143/08, o Conselho Federal de Contabilidade aprovou a NBC T 19.4 que trata da Subvenção e Assistência Governamentais, cujos termos são os constantes do Pronunciamento Técnico CPC-07.

Como visto, os benefícios fiscais podem caracterizar-se de várias formas. Uma delas, a mais ampla, são os subsídios, que, no contexto deste trabalho, se opta por uma construção ampla da seguinte definição: concessão de vantagens tributárias ou alocação de recursos por parte do 
ente governamental às empresas com o objetivo de incentivar o desenvolvimento de determinado setor de interesse da economia, desenvolver determinadas áreas específicas ou qualquer outro objetivo determinado por lei, com o intuito de baixar o preço final dos produtos das empresas, de forma que eles possam adquirir competitividade no mercado interno e externo.

Nessa mesma linha de raciocínio, inserem-se os incentivos fiscais como um dos diversos tipos de subsídios. Eles se caracterizam como redução ou eliminação, direta ou indireta, do respectivo ônus tributário, definido em norma específica.

Guinet e Kamata (1996, p. 22) indicam que muitos países associados à OCDE descobriram que os incentivos fiscais oferecem vantagens notáveis sobre os subsídios. Eles justificam tal afirmativa da seguinte forma:

Primeiro, e acima de tudo, eles envolvem menos interferência no mercado e assim permitem aos tomadores de decisão do setor privado conservar autonomia ao delinear suas estratégias de pesquisas e desenvolvimentos em resposta aos sinais do mercado; esta característica aumenta também a viabilidade de implantação de suas políticas. Segundo, os incentivos fiscais requerem menos instâncias burocráticas e compreendem exigências menos detalhadas para o recebimento de assistência do que subsídios doados com base em cada projeto. Terceiro, uma política que envolve incentivos fiscais é na maior parte mais prontamente previsível e mais estável que aquela que requer apropriações periódicas dos orçamentos governamentais.

Dentro desse mesmo conceito, Coen (1968, p. 200) já acreditava que

os incentivos fiscais estimulam despesas de capital em duas maneiras. Primeira, pela redução do montante de impostos que devem ser pagos sobre o lucro dos ativos, ou pela alteração do momento do pagamento dos impostos para o futuro, os incentivos fiscais aumentam a taxa de retorno sobre o capital após imposto de renda. Segundo, ao reduzir obrigações fiscais, os incentivos fiscais incrementam o fluxo de caixa da empresa (lucros após imposto de renda mais encargos de depreciação para fins fiscais), que é uma medida de fundos internos disponíveis para investimentos e alguns acreditam ser uma determinante importante de gastos com investimentos.

A OMC direciona uma de suas preocupações centrais à existência de especificidades na implantação de políticas econômicas. Essas especificidades ocorrem quando uma medida governamental é projetada para beneficiar uma indústria ou empresa ou um grupo de indústrias e empresas em particular. Isso ocorre nos casos em que o governo limita o acesso a certos subsídios para um grupo de indústrias ou para uma região geográfica em particular. Nesses casos, os subsídios não são igualmente disponíveis para todos, o que pode caracterizar-se como concorrência desleal e ocasionar uma guerra fiscal entre as nações. 
Jenkins e Jenkins (2007, p. 1-3) lembram que

\begin{abstract}
A Organização Mundial do Comércio (OMC) é a mais importante organização internacional a lidar com regras globais de comércio entre as nações. Sua principal função é assegurar que o comércio internacional flua tão suave, previsível e livremente quanto possível. Seus meios efetivos de operação são a promoção de políticas regulatórias a favor de uma competição não discriminatória e justa.
\end{abstract}

Logo, de acordo com as regras da $\mathrm{OMC}$, se uma determinada nação concede uma isenção de imposto de renda às empresas que operam nas Zonas de Processamento de Exportação e nas Zonas de Livre Comércio, tal isenção se constitui em subsídio à exportação. Assim, essa isenção sobre o imposto de renda caracteriza-se como instrumento de competição discriminatória e injusta.

Os subsídios podem afetar, de forma adversa, o bem-estar em outros países. Partindo-se do pressuposto de que um determinado país consiga um incremento nos seus volumes de exportação, em decorrência desses subsídios a um custo aceitável, ocasionará perdas naquele outro país produtor desse mesmo bem. O efeito dos subsídios ocasiona mudanças nas preferências dos consumidores e, portanto, faz com que esses invistam em bens que foram precificados abaixo daqueles sem subsídios.

Segundo Galvão (1999, p. 1046), o Brasil não infringe a legislação da OMC com relação aos incentivos fiscais concedidos às regiões menos favorecidas. Assim, ele apresenta suas idéias:

No Brasil, a legislação de incentivos fiscais e financeiros às regiões menos desenvolvidas respeitam rigorosamente os princípios da "neutralidade" e da "automaticidade", sendo esses princípios, aliás, regras consignadas na legislação referida desde suas origens, no início dos anos 60 .

Deve-se registrar o fato de que os incentivos fiscais concedidos pelo modelo industrial Zona Franca de Manaus não alcançam subsídios que se caracterizam como isenção ou redução do imposto de renda. Em regra geral, são incentivos fiscais, caracterizados como subvenções, isenções, reduções e diferimento incidentes sobre tributos indiretos internos e externos, com o objetivo de criar e desenvolver naquela região um centro indutor de desenvolvimento, cujas atividades econômicas, sejam por dificuldades logísticas, distância dos grandes centros consumidores, dentre outras, não atrairiam agentes econômicos empreendedores privados. 


\subsubsection{Zonas de Livre Comércio}

O termo Zona de Livre Comércio é encontrado na literatura para designar tanto uma determinada área incentivada dentro de um determinado país (HAMADA, 1974; GUINET; KAMATA, 1996; COELHO, 2006), como para designar uma área de integração econômica entre países. (BASTOS, 1998; BAUMANN et al., 2004).

Hamada (1974, p. 225) afirma que "Ao abrir uma zona de livre comércio, o país fornece um local onde os preços internacionais prevalecem." ${ }^{\prime 11}$ Coelho $(2006$, p. 62) acrescenta que

com a finalidade de favorecer o progresso e o desenvolvimento das áreas fronteiriças específicas da Região Norte do País e de aumentar as relações bilaterais com os países vizinhos, foram criadas Áreas de Livre Comércio de importação e exportação sob regime fiscal especial, que permitem a entrada de produtos estrangeiros com suspensão dos pagamentos de impostos.

Numa outra dimensão, Bastos (1998) esclarece que os termos Zona Franca e Zona de Livre Comércio não são equivalentes, pois essa última constitui fenômeno internacional, implementada por meio de tratados e acordos entre os respectivos Estados-membros. Segundo Baumann et al. (2004, p. 106), o conceito de Zonas de Livre Comércio está inserido na teoria da integração, uma das teorias de sustentação do comércio internacional e pode ser caracterizada como uma área de livre comércio que implica concessões comerciais generalizadas, compreendendo a maior parte (ou a totalidade) da pauta comercial entre os países envolvidos.

Como se observa, o termo Zona de Livre Comércio é apresentado por um conceito amplo. Do fato de não haver um consenso sobre a sua utilização, não se pode inferir se estão corretos ou errados, inclusive eles podem aparecer, dependendo de alguma característica específica de produção e/ou comercialização, como Zonas Econômicas Livres (ZEL), Zonas Francas (ZF), Zonas de Processamento de Exportação (ZPE), Zonas Econômicas Especiais (ZEE), Zonas Livres de Impostos (ZLI), dentre outras.

Assim, o Quadro 1, a seguir, mostra uma classificação organizada a partir dos diversos conceitos encontrados na literatura pesquisada e construídos mediante o agrupamento de características.

\footnotetext{
11 "By opening a duty-free zone, the country provides a location where international prices prevail."
} 
Quadro 1 - Classificação das Zonas de Livre Comércio

\begin{tabular}{|c|l|l|}
\hline \multirow{4}{*}{$\begin{array}{c}\text { Zonas de Livre } \\
\text { Comércio } \\
\text { (ZLC) }\end{array}$} & Comerciais & Lojas Francas (LF) \\
\cline { 2 - 3 } & Industriais & Zortos Francos (PF) \\
& Zonas Francas (ZF) \\
\cline { 2 - 3 } & Mistas & Combinação de um ou mais tipo das anteriores \\
\hline
\end{tabular}

$\mathrm{Na}$ maioria dos conceitos, encontram-se componentes similares que, em suma, podem ser agrupados para caracterizar as Zonas de Livre Comércio. Para o presente trabalho, deixando de lado o conceito geral relativo à teoria da integração, que consiste na eliminação de todas as barreiras tarifárias e não tarifárias que incidem sobre o comércio dos países, as Zonas de Livre Comércio (ZLC) são consideradas como sinônimas de Zonas Econômicas Livres (ZEL), assim definidas como aeroporto, porto ou qualquer outra área designada para importação de matérias-primas, componentes, produtos semimontados, semiacabados ou prontos sem o pagamento de tributos ${ }^{12}$. Tais itens podem ser armazenados, demonstrados, montados ou processados para reexportação ou entrar no mercado doméstico do país importador (após o devido pagamento dos tributos). São também conhecidas como Zonas Comerciais Internacionais ou Zonas Livres. ${ }^{13}$

O propósito das Zonas de Livre Comércio, na maioria dos países, é fornecer um ambiente mais apropriado para a produção destinada à exportação até que a economia como um todo se reestruture de forma a encorajar essa produção numa escala maior. (JENKINS; JENKINS, 2007, p. 1-3).

Ao analisar os aspectos econômicos de uma Zona de Livre Comércio, Hamada (1974, p. 225) afirma que, ao abrir uma Zona de Livre Comércio, o país fornece um local em que os preços internacionais prevalecem.

\footnotetext{
${ }^{12}$ Disponível em: $<$ http://www.wikipedia.org.pt $>$. Acesso em: 12/12/2008.

${ }^{13}$ Disponível em: <http://www.businessdictionary.com>. Acesso em: 12/12/2008.
} 
As Zonas de Livre Comércio (ZLC) podem ser divididas em três tipos: comerciais, nas quais apenas é exercida a atividade comercial; industriais, nas quais são realizadas operações industriais e mistas, nas quais são realizadas operações comerciais e industriais.

Dentre as Zonas de Livre Comércio (ZLC) classificadas como comerciais, podem-se enumerar as lojas francas, os portos francos e as zonas francas.

Segundo Coelho (2006, p. 58), as Lojas Francas são estabelecimentos comerciais localizados na zona primária de porto ou aeroporto que adquirem mercadorias estrangeiras ou nacionais, com a finalidade de vendê-las aos passageiros de viagens internacionais.

Os Portos Francos são definidos como uma Zona Econômica Livre que abrange toda a área de um porto na qual é permitida a entrada de mercadorias em geral sem o devido pagamento dos tributos e que se destinam à comercialização para o mercado doméstico do país ou para reexportação. $^{14}$

As Zonas Francas são designadas por áreas cercadas e controladas nas quais as mercadorias são trazidas sem o pagamento de tributos para posterior processamento ou reexportação. Os tributos devem ser pagos se esses produtos forem introduzidos no mercado doméstico do país em que as Zonas Francas estejam localizadas. ${ }^{15}$

Furlan (2008, p. 45) acrescenta que

[...] sob o enfoque tributário, zona franca é uma área legalmente delimitada com o fito de receber um tratamento especial, ou melhor, um tratamento tributário que se supõe propositalmente diferenciado para que se possa dar efetividade ao princípio maior da isonomia.

Com relação às Zonas de Livre Comércio (ZLC) consideradas como industriais estão as Zonas de Processamento de Exportação (ZPE) e as Zonas Industriais Especiais (ZIE).

As Zonas de Processamento de Exportação (ZPE) são tipos de Zonas de Livre Comércio criadas pelos governos com o propósito de desenvolvimento dos seus países para promover a indústria e a exportação comercial. Além dos benefícios de uma Zona de Livre Comércio,

\footnotetext{
${ }^{14}$ Idem, idem.

${ }^{15}$ Idem, idem.
} 
essas zonas oferecem outros incentivos como isenções de certas taxas e facilidades regulatórias. Elas são, também, chamadas de Zonas Econômicas de Desenvolvimento ou Zonas Econômicas Especiais. ${ }^{16}$

No ordenamento jurídico brasileiro, segundo o Decreto n. 6759, de 5 de fevereiro de 2009, as Zonas de Processamento de Exportação caracterizam-se como áreas de livre comércio de importação e exportação, destinadas à instalação de empresas voltadas para a produção de bens a serem comercializados no exterior, objetivando a redução de desequilíbrios regionais, o fortalecimento do balanço de pagamentos e a promoção da difusão tecnológica e do desenvolvimento econômico e social do País.

Por seu turno, entende-se que as Zonas Industriais Especiais caracterizam-se como áreas destinadas às indústrias, localizadas em portos, aeroportos, terminais retroportuários ou outra qualquer outra área designada sem a finalidade expressa e delimitada como as anteriores.

As Zonas de Processamento de Exportação, criadas pela Lei n. 11.508, de 20.07.2007, assemelham-se ao modelo convencional adotado por uma grande quantidade de países ao redor do mundo. Trata-se de um regime aduaneiro diferenciado, oferecendo às empresas, ali instaladas, facilidades tributárias, aduaneiras, cambiais e de controle administrativo das operações de comércio exterior, notadamente com sua produção total ou a maior parte dela destinada ao mercado consumidor externo.

As Zonas de Processamento de Exportação são derivações das Zonas de Livre Comércio. Elas são criadas pelos governos para promover estratégias voltadas à exportação com o objetivo de alcançar crescimento e prosperidade. Segundo Jenkins e Jenkins (2007, p. 1-3), alguns países têm obtido sucesso em alcançar esse objetivo e foram capazes de reformar suas economias, enquanto outros ainda se encontram em um estágio inicial, em que muitas mudanças precisam ser feitas, principalmente em termos de aduana, administração comercial para incrementar uma política geral e um ambiente administrativo para o comércio internacional.

Pelas razões acima, as Zonas de Processamento de Exportação (ZPE) são consideradas um dos mecanismos mais usados, ao redor do mundo, com o objetivo de estratégia de

\footnotetext{
${ }^{16}$ Idem, idem.
} 
desenvolvimento econômico por meio de uma política industrial. Apenas como ilustração, cite-se o caso da China que utiliza seis modelos distintos de ZPEs: zonas de desenvolvimento econômico e tecnológico; zonas econômicas especiais; zonas de desenvolvimento de alta tecnologia; zonas fronteiriças de cooperação econômica; zonas francas turísticas e zonas de processamento de exportação propriamente ditas. (NAM; RADULESCU, 2004).

Miyagiwa (1986, p. 337) ao escrever sobre as Zonas de Livre Comércio já defendia que:

as Zonas de Livre Comércio (ZLC) são uma parte integrante de uma estratégia de desenvolvimento voltada para a exportação, recentemente adotada por muitos governos de países menos desenvolvidos. ${ }^{17}$

Hamilton e Svensson (1982 p. 45) dizem que

Nessas zonas, as empresas geralmente contam com várias conveniências e facilidades: isenção de impostos sobre equipamentos, materiais e produtos intermediários importados, [...]; procedimentos administrativos e controles de trocas externas são minimizados; atividade sindical é desencorajada ou suprimida e assim por diante. ${ }^{18}$

Entretanto, eles questionam o fato de os problemas sociais e políticos envolvidos terem recebido pouca atenção em discussões públicas em alguns países industrializados. E, além do mais, na literatura sobre comércio internacional, surpreendentemente, poucas são as tentativas que foram feitas para analisar as questões teóricas levantadas pela existência das ZLCs.

Krugman (1991, p. 34) apresenta um outro ponto de vista econômico, ao alertar que

Uma visão mais sofisticada enxerga sombras tanto econômicas como políticas. As zonas de livre comércio não são necessariamente uma coisa economicamente boa, porque podem levar a desvios comerciais ao invés de criação de comércio. Na política de comércio internacional altamente imperfeita, as zonas de livre comércio regionais poderiam perturbar o equilíbrio de forças que permitiram a criação de um sistema mundial de comércio razoavelmente liberal. ${ }^{19}$

\footnotetext{
17 “[...] FTZs are an integral part of an export-oriented development strategy recently adopted by many LDC governments."

18 "In these zones, firms are usually provided with various conveniences and facilities: exemption from duties on imported equipment, materials and intermediate goods, [...]; administrative procedures and foreign-exchange controls are minimized, trade-union activity is discouraged or suppressed; and so forth."

19 "A more sophisticated view sees both economic and political shadows. Free trade areas are not necessarily a good thing economically, because they may lead to trade diversion rather than trade creation. In the highly imperfect politics of international trade, regional free trade zones could upset the balance of forces that has allowed the creation of a fairly liberal world trading system."
} 
Quando da criação de uma Zona de Livre Comércio, os países em desenvolvimento, geralmente, buscam proteção mais por meio de tarifas de importação do que mediante tarifas de exportação. Logo, a discussão sobre incentivos a investimentos estrangeiros torna-se indispensável porque os incentivos são voltados para a produção na área delimitada e não para o capital estrangeiro a ser investido.

Hamada (1974, p. 225) esclarece que

[...] os tipos de indústrias em que os investimentos estrangeiros são permitidos são limitados àqueles que promovam exportações e que não interfiram nas atividades de exportação das firmas da zona doméstica. $\mathrm{Na}$ maioria dos casos, os trabalhadores se deslocam da zona doméstica, e o consumo é feito nessa região, já que um dos propósitos de estabelecer uma zona de livre comércio é manter a indústria doméstica ainda protegida. ${ }^{20}$

Como a ZLC pressupõe a isenção de tarifas aos bens comercializados entre os sócios, torna-se imperativo determinar até que ponto determinado produto é originário de um país membro da ZLC ou foi importado de um terceiro mercado e está sendo reexportado para dentro da Zona. A determinação da "origem" de um produto dá-se por meio do Regime de Origem, mecanismo indispensável em qualquer acordo de livre comércio.

A teoria de investimento estrangeiro foi desenvolvida primeiramente como a teoria dos movimentos dos fatores, mas, recentemente, tem sido tratada como uma teoria de transferência de habilidades tecnológicas. Logo, estuda-se a análise de dois casos de investimentos estrangeiros: na forma de movimento de capitais e na forma de transferência tecnológica. (Ibid., p. 225). ${ }^{21}$

Quando o investimento é feito na forma de movimento de capitais pelo fato de o país anfitrião conceder quaisquer incentivos sobre o imposto de renda, caracteriza-se como promoção de políticas regulatórias a favor de uma competição discriminatória e injusta, o que é altamente condenado pela OMC. Mas, se o investimento se dá por meio de transferência tecnológica,

\footnotetext{
20 "[...] the types of industries in which foreign investments are allowed are limited to those that promote exports and that do not interfere with exporting activities of the domestic zone. In most cases, laborers commute from the domestic zone, and consumption is carried out in domestic region. For, one purpose of establishing a duty-free zone is to keep the domestic industry still protected."

21 "The theory of foreign investment was developed at first as theory of factor movements, but it has recently been treated as a theory of the transfer of technological skills. Thus we shall study two cases: foreign investment in the form of capital movements and in the form of technological transfer."
} 
existe um elevado grau de incentivo à sua implantação tutelado sob o conceito de desenvolvimento econômico.

Na visão de Hamilton e Svensson (1982, p. 45), nota-se que os investimentos estrangeiros são mais subsidiados nas ZLCs do que nas zonas domésticas. ${ }^{22}$ Eles continuam sua análise afirmando que o investimento estrangeiro é de fato subsidiado de duas formas:

Primeiro, dada a proteção ao produto de capital intensivo na zona doméstica, salários domésticos são artificialmente baixos. Logo, o investimento estrangeiro é subsidiado quando as firmas têm acesso a essa mão de obra de salário baixo. Segundo, dada a diferença entre preços domésticos e externos, pode existir um elemento de subsídio adicional no sentido de que o salário a preços mundiais é menor do que o salário a preços domésticos. ${ }^{23}$

Eles concluem sua análise, afirmando diferentemente do modelo desenvolvido por Hamada (1974), que os investimentos estrangeiros são de fato subsidiados, mas não pela ausência de tarifas numa Zona de Livre Comércio, mas pela existência de tarifas em uma zona doméstica.

Nam e Radulescu (2004, p. 7) relatam que, ultimamente, o conceito de Zona Econômica Livre evoluiu e diversificou-se. Dentre os diversos fatos que ilustram esse desenvolvimento, podese citar a diversificação de suas localizações. Ao invés de permanecerem cada vez mais concentradas em uma bem definida e determinada área territorial, os investimentos e outros tipos de incentivos fornecidos nas Zonas Econômicas Livres, tais como concessões fiscais, facilidade de regulamentações etc., foram sendo gradualmente estendidos - ao longo do tempo - para outras empresas, tanto locais como estrangeiras, que operam em outros lugares do país. Um desses exemplos foi o que se passou na Hungria. Outro exemplo de evolução e diversificação diz respeito ao grande número de Zonas de Processamento de Exportação que adquiriu, adicionalmente, funções de processamento de importação. Nam e Radulescu (2004, p. 7) citam, como exemplo, o caso da Zona Franca de Manaus no Brasil que, agora, opera quase que exclusivamente para o mercado doméstico. Eles enumeram os principais fatores que têm feito tais tendências em direção ao processamento de importações, a saber:

\footnotetext{
22،Finally, we noted that foreign investment was subsidized more in the free zone than in domestic zone."

23 "First, given the protection of the capital-intensive good in the domestic zone, domestic wages are artificially low. Thus, foreign investment is subsidized as firms have access to this low-wages labor. Second, given the difference between domestic and foreign prices, there may be an additional subsidy element in that the wage at world prices is lower than the wage at domestic prices."
} 
- a dificuldade técnica de controlar contrabandos de produtos e tecnologia oriundos da zona para outras partes do país anfitrião;

- as pressões combinadas dos consumidores locais (que desejariam ter acesso a e têm condições financeiras de adquirir os produtos de alta qualidade produzidos na zona) e investidores estrangeiros (que são atraídos pela lucratividade potencialmente alta das vendas no mercado local, como no caso da China) e

- políticas governamentais para encorajar ligações locais em troca de acesso ao Mercado local. ${ }^{24}$

Um fator de desenvolvimento importante considerado por Nam e Radulescu (2004, p. 7) foi o estabelecimento de firmas domésticas nas ZEL. Eles citam a Índia e a China como exemplos. Primeiramente, a Índia por tornar compulsória a participação local quando uma firma estrangeira deseja investir em uma ZEL. Eles complementam com a afirmativa de que o crescimento da importância das empresas domésticas se comprova pelo fato de que, atualmente, mais de dois terços de todas as empresas localizadas nas ZEL de países em desenvolvimento são totalmente propriedades de firmas nativas ou joint ventures entre companhias domésticas e parceiros estrangeiros.

No caso da China, Nam e Radulescu (2004, p. 8) registram que as Zonas Econômicas Especiais têm se expandido ao longo das enormes áreas costeiras, em vez de permanecerem em pequenos enclaves industriais e acrescentam:

\begin{abstract}
Inicialmente, a implantação de quatro ZEE na parte do sul da China em 1978/79 objetivava principalmente alcançar uma proximidade geográfica com Hong Kong, Macau e Taiwan no desejo de explorar ao máximo a vantagem da mais alta concentração de chineses fora do continente. Com relação às atividades de investimentos estrangeiros, algumas mudanças significativas foram feitas a partir daí. Essas incluem, por exemplo, se distanciar da circunscrição de uma ZEE para uma área geográfica mais ampla, levando a subseqüente expansão das ZEE ao longo da costa, transferindo a concentração do desenvolvimento imobiliário (incluindo hotéis e outras instalações turísticas) em direção às indústrias, e abandonando os investimentos baseados em joint ventures para empresas próprias $^{25}$.
\end{abstract}

\footnotetext{
24 “. the technical difficulty of controlling smuggling of products and technologies from the zone into other parts of the host country,

. the combined pressures of local consumers (who would like to have access to and can also afford the highquality goods produced in the zone) and foreign investors (who are attracted by the potentially high profitability of sales in the local market, as is the case in China), and

. governments' policy to encourage local linkages in exchange for access to the local market."

25 "The selection of initially four SEZs in the southern part of China in 1978/79 was mainly aimed at achieving a geographic proximity to Hong Kong, Macao and Taiwan in order to fully exploit the advantage of the highest concentration of overseas Chinese. Regarding the foreign investment activities, some significant shifts were made thereafter. These include, for example, moving away from the SEZ to a broader geographical spread leading to the subsequent expansion of SEZs along the coast, shifting concentration from real estate development (including hotels and other tourist facilities) towards industry, and turning away from jointventure-based investment to wholly owned enterprises."
} 
Com a crescente e rápida evolução das áreas de serviços e telecomunicações, aliada a uma globalização cada vez mais efetiva, eles acreditam que, em um futuro próximo, ocorrerá um redirecionamento de uma ZEL orientada para a fabricação clássica para uma zona moderna orientada para serviço. Isso mostra a importância crescente do setor de serviços no total das atividades econômicas, causada, principalmente, pelo galopante desenvolvimento da tecnologia da informação e da telecomunicação. (NAM; RADULESCU, 2004, p. 8).

Nesse sentido, uma crescente orientação para serviços de algumas ZEL é, portanto, um conceito muito mais amplo e mais ambicioso do que o de portos livres, porque engloba não apenas atividades de transportes e negócios tradicionais mas também serviços comerciais e financeiros modernos como bancos, seguros e processamento de dados. O alargamento do conceito de uma ZEL como uma zona voltada para serviços poderia, inclusive, englobar alguns serviços de turismo ou educação.

Por outro lado, ao analisar as experiências passadas ao redor do mundo, Nam e Radulescu (2004, p. 8) dizem que:

as ZEL geralmente não têm sido desenvolvidas de acordo com as linhas originalmente planejadas. E mais, os benefícios econômicos e sociais de uma zona tendem a ser muito maiores (ou muito menores) que os antecipados, e na maioria dos casos muito diferentes daquilo que tinha sido originalmente planejado. Esses fatos estão bem indicados pela transformação de um grande número de zonas em monoculturas industriais em vez de parques industriais bem equilibrados e altamente diversificados almejados pelos planejadores. $\mathrm{O}$ fenômeno deve-se a um grande número de razões econômicas e sociológicas complexas que sugerem que as ZEL mantêm uma vida própria e um dinamismo interno que são difíceis de prever em um processo de planejamento. ${ }^{26}$

Eles mencionam que os vários erros cometidos no planejamento e projeto de uma ZEL em muitos países devem-se, principalmente, ao fato de escolha de uma região subdesenvolvida com inadequadas comunicações aéreas e rodoviárias para a localização da ZEL. Acrescentese o fato de ser dada pouca atenção a outras infraestruturas básicas, como oferta de eletricidade e comunicações; acessibilidade inter-regional e internacional da região; um distanciamento entre as habilidades da mão de obra nativa e aquelas exigidas pelas novas atividades de produção etc..

\footnotetext{
26 "FEZs have not usually developed along lines originally planned. Furthermore, the economic and social benefits of a zone tend to be much greater (or much smaller) than anticipated, and in most cases quite different from what had originally been planned. These facts are well indicated by the development of a number of zones into industrial mono-cultures, rather than into the well-balanced and highly diversified industrial parks envisaged by the planners. The phenomenon is due to a number of complex sociological and economic reasons
} 
Numa análise macro, percebe-se que o desenvolvimento bem sucedido de uma zona parece ser guiado pela habilidade e flexibilidade das autoridades locais em identificar imprevistos e, tempestivamente, realizarem as mudanças de curso necessárias para ajustar a estrutura institucional e o funcionamento da zona aos novos problemas que surgem com o seu desenvolvimento e, de uma maneira mais geral, desenvolver um mecanismo de acompanhamento, avaliação e controle efetivo e de solução de problemas.

Machado (2000, p 1-2) defende a tese de que a instalação de indústrias atraídas pela isenção, aqui ampliado o conceito para subsídios fiscais de toda natureza, em que estão inseridos os incentivos fiscais especiais, além de não implicar renúncia à arrecadação, promove o aumento dessa, por via indireta na medida em que aumenta a renda e o consequente poder de compra com a oferta de empregos. Acrescenta, ainda, que o incentivo fiscal para empreendimentos novos é a melhor forma de promover o desenvolvimento econômico das regiões pobres do país e, assim, reduzir as desigualdades econômicas regionais.

As transformações levadas às regiões anfitriãs para a instalação dos parques industriais incentivados são, de fato, percebidas imediatamente. Além do crescimento econômico, surge uma melhoria na autoestima da população decorrente da elevada expectativa de oportunidade de trabalho, devido, principalmente, à escassez de emprego e tendo no poder público local, em muitos casos, a única fonte de renda.

As necessidades de investimentos públicos surgem a partir da decisão em receber as empresas incentivadas, melhorando sua infraestrutura, tais como: água potável, energia elétrica, saneamento, pavimentação, postos de saúde, escolas, enfim, todo um conjunto de benefícios que transformam pacatas cidades do interior do Estado em grandes polos industriais.

A Zona Franca de Manaus, por época da sua criação, poderia ser questionada quanto aos aspectos logísticos e de infraestrutura que a região dispunha naquela época, entretanto, para Furlan (2008, p. 33)

[...] a Zona Franca de Manaus não se constitui efetivo regime de zona franca, entendida esta locução em sua acepção própria, técnico-econômica e jurídico-aduaneira. A rigor, Zona Franca de Manaus significa Sub-região de Manaus, pois não se cuida de área aduaneira de livre comércio

which suggest that FEZs maintain a life of its own and an internal dynamism that one can hardly predict in the planning process." 
internacional, e, sim, âmbito espacial parcelar de nosso ordenamento jurídico inerente a determinado regime de intervenções de desenvolvimento.

Diante dos conceitos aqui apresentados, a Zona Franca de Manaus, pela própria definição legal, apresenta-se como uma Zona de Livre Comércio mista, no mais amplo conceito da expressão, por apresentar características de livre comércio de importação e de exportação e de incentivos fiscais especiais concedidos às indústrias que realizam processos de industrialização nas mais diversas modalidades, com exceção de acondicionamento e recondicionamento.

Barroso (2008) acrescenta que o próprio art. 1ํ do Decreto-lei n. 288 já amplia o conceito da Zona Franca de Manaus ao estabelecê-la como área de livre comércio, de importação e exportação e de incentivos fiscais especiais. Ele complementa que

[...] o modelo implantado em Manaus não se limita à desoneração de tributos aduaneiros nem à eliminação de barreiras à livre circulação de mercadorias, e muito menos a uma ficção jurídica de extraterritorialidade, cuja finalidade seria a entrepostagem de mercadorias estrangeiras destinadas à reexportação. (Ibid., p. 300)

Furlan (2008, p. 50) finaliza acreditando que se pode "inferir o papel crucial da Zona Franca de Manaus para promover o desenvolvimento sócio-econômico da Região Norte - tendo como diretrizes constitucionais o princípio da igualdade a que se refere o Estado Democrático de Direito, bem como a preservação do meio ambiente."

\subsection{Teoria sobre Comércio Exterior}

Em uma análise sobre a teoria de comércio internacional, Heller (1970, p. 2) considera-a como uma extensão da teoria econômica geral aos problemas especiais que surgem no comércio entre nações. ${ }^{27}$ Com a evolução das suas reflexões, ele ressalta sua complexidade porque, em determinado momento, a teoria de comércio internacional irá tratar de um número de variáveis maior do que outros campos da economia.

\footnotetext{
27 "La teoría del comercio internacional puede considerarse como uma extensión de la teoría económica general a los problemas especiales que surgen en el comercio entre naciones."
} 
As quatro suposições básicas a serem consideradas em uma teoria pura de comércio internacional apresentadas por Heller (1970, p. 21) são:

- O que determina a direção do comércio?

- Intimamente ligada à direção do comércio está a questão sobre o volume físico do comércio internacional e os preços a que se comercializam os bens.

- Também são de interesse os efeitos das retrições ao comércio.

- $\quad \mathrm{O}$ efeito do comércio livre e o comércio restrito no bem-estar da economia.

Na avaliação de Barral (2007, p. 13), “A concepção de Adam Smith quanto às vantagens do comércio internacional seguia sua lógica de que o trabalho seria a principal fonte de riqueza de uma nação." Logo, como resultado, a divisão do trabalho proporcionaria o aumento da especialização e, consequentemente, elevaria a produtividade econômica. Já no âmbito internacional, a divisão do trabalho resultaria das diferenças existentes entre os países. Tais diferenças confeririam a cada país uma vantagem específica e, por essa razão, cada país deveria se especializar nos produtos mais importantes para os quais tivesse mais aptidão e recursos.

Segundo Silber (2006, p. 5), “O princípio das vantagens comparativas da teoria clássica de comércio internacional prevê que uma nação exportará os produtos com custos de oportunidade relativamente menores e importará os produtos nos quais tenha custos de oportunidade relativamente maiores." Ele acrescenta que "A teoria do comércio internacional indica que a disponibilidade de bens no mundo será maior caso os países se especializem de acordo com a sua vantagem comparativa." (Ibid., p. 7).

Por outro lado, Rijnvos ( 1976, p. 3) afirma que o comércio internacional inclui outros custos e variáveis não contemplados pela teoria dos custos comparativos, mesmo quando libertada por razões de ordem econômica, política e considerações monetárias.

Krugman e Obstfeld (1994), ao discutirem sobre a economia internacional, consideram que um princípio importante a ser entendido é o das vantagens comparativas. Esse princípio, conhecido como modelo de Ricardo, se contrapõe ao princípio clássico de Adam Smith. Esse modelo demonstra que as vantagens comparativas, ou força relativa, de um país sobre outro 
na produção de um produto específico depende das diferenças internacionais da produtividade da mão de obra. Nesse modelo, é usada apenas uma entrada na produção - trabalhadores - e as diferenças na produção por trabalhador em diferentes indústrias em diferentes países determinará o padrão de comércio.

Logo, dentro desse contexto, as Zonas de Livre Comércio são criadas sem ferir o princípio das vantagens comparativas da teoria clássica de comércio internacional, elaborada por Adam Smith, que prevê que uma nação exportará os produtos com custos de oportunidade relativamente menores, e o princípio defendido por Ricardo no qual a vantagem de um país sobre outro na produção de um produto específico depende das diferenças internacionais da produtividade da mão de obra.

Hamada (1974), Hamilton e Svensson (1982), Miyagiwa (1986) e Nam e Radulescu (2004) observam que a criação de Zonas Especiais ao redor do mundo leva em conta para a decisão de sua instalação, em determinadas situações, fatos preponderantemente ligados à produtividade do trabalho. Outras vezes, em alguns países com um nível tecnológico um pouco mais elevado, a decisão de instalação é decorrência de um conjunto de fatores que constroem a vantagem comparativa desse país sobre outro. Pode-se considerar como parte desses fatores os aspectos relacionados à concessão de infraestrutura, mão de obra especializada, estrutura logística, facilidades aduaneiras e burocráticas e incentivos fiscais concedidos pelo país anfitrião.

Lastres (1997, p. 43) mostra que

Em praticamente todos os países, os governos têm considerado imperativo contrabalançar o grau elevado de abertura ao exterior que se seguiu à importante redução de barreiras tarifárias, mobilizando e desenvolvendo uma ampla gama de instrumentos, para melhorar a competitividade de suas empresas, tanto no que se refere às exportações quanto aos mercados internos abertos à concorrência externa.

Para Krugman e Obstfeld (2007, p. 183), os países buscam “[...] estabelecer uma área de livre comércio, na qual os bens de cada país possam ser enviados ao outro sem tarifas, mas na qual os países fixem tarifas de maneira independente do resto do mundo." Em determinado momento, com o objetivo de proteger o seu parque industrial, os países realizam controle do grau de abertura ao mercado internacional por meio de barreiras tarifárias ou, quando inviáveis, barreiras não tarifárias. 
Ao considerar a vantagem comparativa dos países em desenvolvimento, ao abrirem seus mercados ao comércio internacional e à instalação de parques industriais, Krugman e Obstfeld (2007, p. 192) defende a utilização de mecanismos temporários por parte dos governos, ao afirmar que

De acordo com o argumento da indústria nascente, os países em desenvolvimento têm uma vantagem comparativa potencial na manufatura, mas as novas indústrias desses países não podem, a princípio, concorrer com as sólidas manufaturas dos países desenvolvidos. Para lhes dar o apoio necessário, os governos devem ajudar temporariamente as novas indústrias, até que elas se tornem fortes o suficiente para enfrentar a concorrência internacional. Desse modo, faz sentido, de acordo com esse argumento, utilizar tarifas ou cotas de importação como medidas para dar início à industrialização.

Logo, os países em desenvolvimento têm buscado a criação de zonas econômicas especiais, quer sob a denominação de zonas industriais especiais, zonas de processamento de exportação, dentre outras, como forma de viabilização dessa vantagem comparativa.

Nesse contexto, Krugman e Obstfeld (2007, p. 194) faz a seguinte observação:

Como estratégia de estímulo ao crescimento de manufaturas, a industrialização pela substituição de importações sem dúvida funcionou. As economias da América Latina geram hoje uma parcela de produto das manufaturas quase tão grande quanto a das nações avançadas.

De fato, a criação da Zona Franca de Manaus, no Brasil, como parque industrial incentivado para a substituição de importações comprova que essa estratégia funcionou e vem funcionando até os dias atuais. Praticamente, todo o consumo do mercado doméstico dos produtos: motocicletas, televisores, aparelhos de áudio, telefonia celular, dentre outros, é procedente daquela zona industrial, conseguindo competir em preço e qualidade com os produtos fabricados no mercado internacional. Essa afirmativa ganha reforço e robustez no Capítulo 3, no qual são apresentadas informações sobre a Zona Franca de Manaus.

\subsection{Teoria dos Stakeholders}

Freeman (1984 p. 31 e 32) relata que a história do conceito de stakeholder parte das idéias originais de Adam Smith (1759), Berle e Means (1932) e Barnard (1938), entretanto, o termo 
stakeholder aparece pela primeira vez, na literatura gerencial, em um memorando interno no Stanford Research Institute, de 1963, hoje conhecido como SRI International, Inc. ${ }^{28}$

O conceito de stakeholder é apresentado por Freeman (1984, pag. 25) como "Qualquer grupo ou indivíduo que pode afetar ou é afetado pela realização dos objetivos da empresa." ${ }^{29} \mathrm{O}$ termo stakeholder pode ser aplicado não somente aos grupos facilmente caracterizados por palavras, tais como clientes ou empregados, mas para todos aqueles que podem ter diferentes e competitivos interesses na firma. (JONES, 1999, p. 408).

A Figura 1 mostra exemplos de categorias de stakeholders, ou seja, diversos grupos que interagem com a entidade empresa e cada um deles com interesses distintos, tornando-se, em determinados momentos, mais fortes ou mais fracos, de acordo com o nível de pressão que sofrem ou exercem.

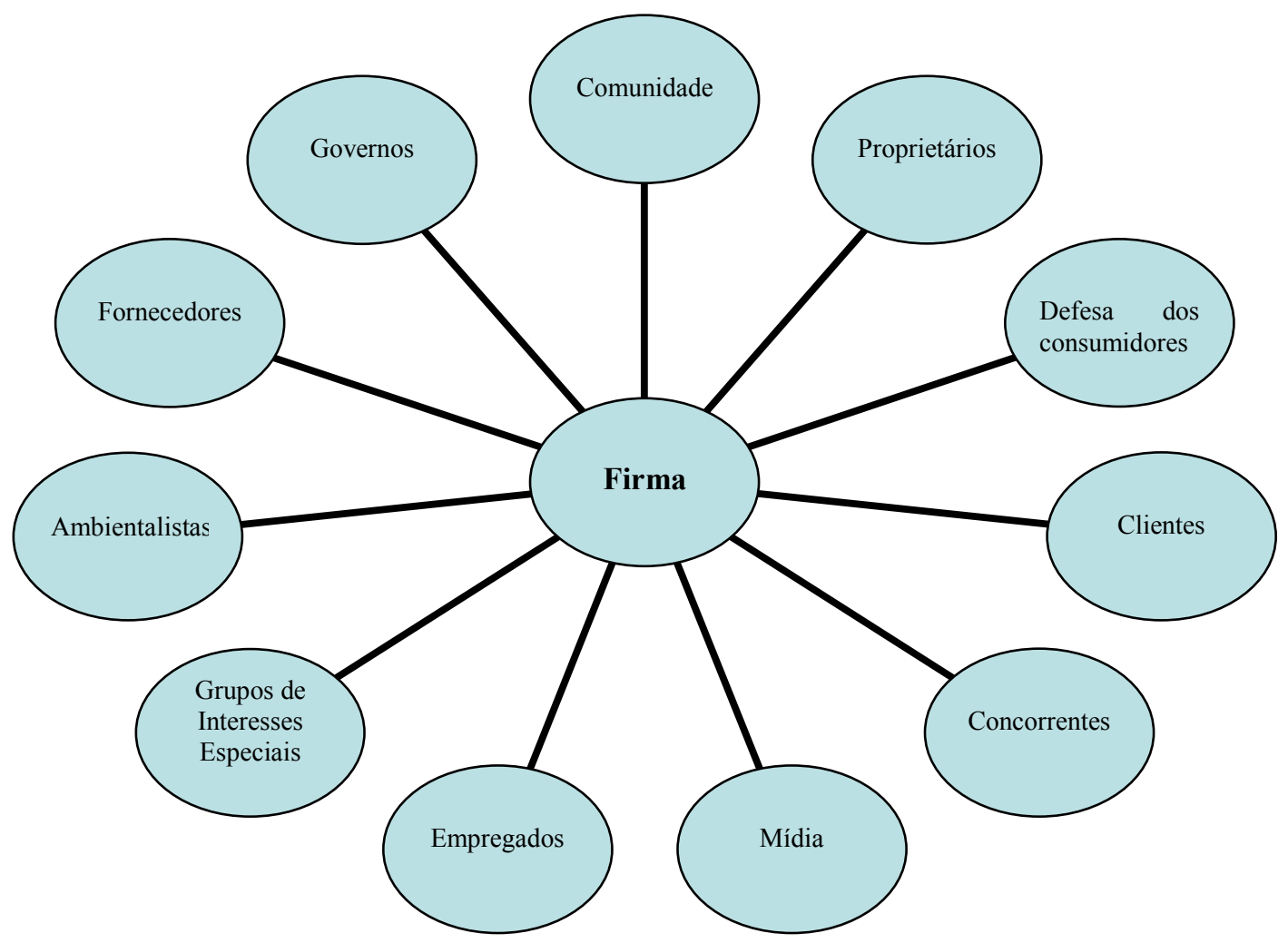

Figura 1: Interação entre a entidade empresa e os stakeholders Fonte: Freeman, 1984

\footnotetext{
28 "The SRI researchers argued that unless executives understood the needs and concerns of these stakeholder groups, they could not formulate corporate objectives which would receive the necessary support for the continued survival of the firm."

29 "Any group or individual who can affect or is affected by the achievement of the firm's objectives."
} 
Mitchell et al. (1997, p. 855) afirmam que não existe mais discordância sobre que tipo de entidade pode ser um stakekholder. Pessoas, grupos, vizinhos, organizações, instituições, sociedades e até o ambiente natural estão, geralmente, aptos para se qualificar como atuais ou potenciais stakeholders. Esses autores utilizam as três teorias organizacionais: a dos custos de transação, a da dependência de recursos e a da agência, para explicarem o que e quem conta efetivamente na firma. Esse poder que cada parte possui sobre o interesse da firma, torna-se uma variável fundamental nas relações entre a administração e os stakeholders. (Ibid., p. 863).

A teoria dos Stakeholders, desenvolvida e estruturada por Freeman (1984), apresenta justificativas teóricas sobre a existência de uma responsabilidade social por parte das empresas perante um grupo que é afetado por suas atividades. Esse grupo é composto, principalmente, pelos seus acionistas, empregados, fornecedores, concorrentes, credores, governos e a sociedade em geral, por interagirem com as atividades das empresas e possibilitarem o ambiente apropriado para a legalização das suas atividades empresariais.

Jones (1999, p. 413-414) utiliza a matriz do dilema dos prisioneiros para explicar a importância de cada parte interveniente no resultado da firma. Esse dilema está diretamente associado à teoria dos jogos, na qual não se deve buscar a maximização da parte individual mas, sim, a maximização de satisfação do grupo como um todo, que, nesse caso, é a empresa em que todos os stakeholders possuem interesses diversos.

Freeman (1984, p. 43) complementa que,

Embora a história do conceito das partes interessadas, em todos os seus disfarces, seja relativamente breve, o conceito pode ser usado para amarrar junto um rico acervo de literatura. As principais preocupações de cada área principal de investigação não são mutuamente exclusivas. As preocupações com a formulação de planos e sistemas de planos para entidades comerciais, com a compreensão do papel da corporação nos sistemas sociais, com a responsabilidade social e a necessidade de teorias integradoras para explicar o comportamento de uma grande população de organizações e seus ambientes são de vital importância para os gestores e os pesquisadores organizacionais. $\mathrm{O}$ conceito de partes interessadas pode ser útil na integração de algumas dessas questões em torno do conceito de estratégia organizacional. ${ }^{30}$

\footnotetext{
30 "While the history of the stakeholder concept, in all of its disguises is a relatively brief one, the concept can be used to tie together a rich body of literature. The major concerns of each main area of research are not mutually exclusive. The concerns with formulating plans and systems of plans for business level entities, with understanding the role of the corporation in social systems, with the social responsibility and the need for integrative theories to explain the behavior of a large population of organizations and their environments are of vital importance to managers and organizational researchers. The stakeholder concept can be useful in integrating some of these issues around the concept of organizational strategy."
} 
Dentre os diversos aspectos da teoria dos stakeholders, chama a atenção, para este trabalho, a afirmação de Donaldson e Preston (1995, p. 67):

[...] a base fundamental da teoria dos stakeholders é normativa e envolve a aceitação das seguintes idéias: a) stakeholders são pessoas ou grupos com interesses legítimos nos aspectos procedimentais e/ou substantivos da atividade da corporação. Stakeholders são identificados pelos seus interesses na corporação, tendo a corporação um interesse correspondente neles ou não; b) os interesses de todos os stakeholders são de valor intrínseco. Isso é, cada grupo de stakeholders merece consideração por si próprio e não meramente por causa das suas habilidades em contribuir com os interesses de algum outro grupo, como o dos proprietários.

Jones (1999, p. 406) considera a Teoria dos Stakeholders como uma teoria instrumental de administração dos stakeholders. Ele faz uma relação entre essa teoria e o equilíbrio de mercado. Uma situação de equilíbrio implicaria que mecanismos de ineficiência de contratos e poderes diferentes entre as partes contratantes poderiam não existir. Os mercados eficientes abandonariam os contratos ineficientes, deixando somente aqueles em que nenhuma das partes se sobrepusesse às demais.

Dessa forma, Jones (1999, p. 408) enumera as seguintes suposições que descrevem a relação entre uma corporação moderna e seu ambiente:

- Firmas possuem relacionamentos, chamados de contratos, com muitos stakeholders;

- $\quad$ Firmas são administradas por gerentes profissionais;

- $\quad$ Firmas existem em mercados em que pressões sobre competitividade influenciam comportamentos, mas, não necessariamente, penalizam comportamentos moderadamente ineficientes.

Os trabalhos de Gray et al. (2001), Deegan (2002) e Van Staden (2002) sugeriram teorias como a teoria da legitimidade, a teoria do stakeholder e a teoria de economia política para explicar e motivar os relatórios voluntários de informações sociais e ambientais, apresentados na literatura nos anos 80 e 90, para se contraporem ao foco estreito do paradigma da utilidade das decisões que se encontrava centrado no fornecimento de informações financeiras, voltadas, principalmente, para credores e investidores. Numa visão crítica, eles buscavam estudar e explicar as posições relativas de poder existente entre a organização, a sociedade e o ambiente em que estão inseridas. 
Segundo Van Staden (2002), a teoria da legitimidade assume que existe um "contrato social" entre a organização e a sociedade. Ele parte de uma citação de Deegan (2002), na qual ele diz que a teoria da legitimidade afirma que as organizações tentam assegurar, continuamente, que suas operações ocorram dentro de limites e normas de suas respectivas sociedades. Elas tentam assegurar que suas atividades sejam percebidas pelas partes de fora, como sendo legítimas, para explicar a base da premissa de que a sociedade dá às corporações, com seu padrão legal e atributos, a autoridade para elas possuírem e usarem recursos naturais e para contratar empregados e, portanto, terem a expectativa de legitimidade que a organização operará dentro de normas aceitáveis.

Van Staden (2002) diz que encontrou grande número de estudos empíricos que têm utilizado a teoria da legitimidade para explicar práticas de produção de relatórios ambientais e sociais. Esses estudos encontraram resultados que são consistentes com a teoria da legitimidade e acreditava-se que as corporações mudariam suas práticas de produção de relatórios quando confrontadas com eventos sociais e ambientais maiores.

Por outro lado, a teoria das partes interessadas (stakeholders) admite que uma organização possui muitas partes interessadas, definidas por Van Staden (2002) como "qualquer agente humano que possa ser influenciado ou que possa influenciar as atividades da organização", e argumenta que todas as partes interessadas têm o direito de ser tratadas de forma justa pela organização. A partir disso, pode-se defender, portanto, que todas as partes interessadas possuem o direito de receber informações sobre os impactos da organização sobre elas.

Diretamente relacionada à teoria da legitimidade está a perspectiva contábil de economia política. A economia política é "a estrutura econômica, política e social dentro da qual a vida humana acontece.” Gray et al. (2001), ao descreverem a economia política clássica, argumentam que a contabilidade fornece suporte à estrutura de poder e ao status quo no capitalismo e, dessa maneira, capacita a exploração da sociedade.

Freeman (2007, p. 3) parte do pressuposto de que a idéia básica é bastante simples, uma vez que

O negócio pode ser entendido como um conjunto de relações entre grupos que têm uma participação nas atividades que compõem o negócio. Negócios giram em torno de como clientes, fornecedores, empregados, financiadores (acionistas, credores, bancos, e assim por diante), 
comunidades e administradores interagem e criam valor. Entender um negócio é conhecer de que modo essas relações funcionam. ${ }^{31}$

Freeman (1984, p. 53) acrescenta que existem pelo menos três níveis para se compreender o processo que uma organização utiliza para gerenciar o relacionamento com seus stakeholders. Primeiramente, deve-se buscar compreender, a partir de uma perspectiva racional, quem são as partes interessadas na organização e quais os desafios percebidos. Em segundo lugar, devese compreender os processos organizacionais utilizados para gerir de forma implícita ou explícita a relação da organização com suas partes interessadas e se esses processos se encaixam com o mapa racional de partes interessadas da organização. Por último, é preciso entender o conjunto de operações ou barganhas entre a organização e seus atores e deduzir se essas negociações se encaixam com o mapa das partes interessadas e os processos organizacionais voltados para essas partes interessadas. Ele conclui que se pode "definir a capacidade de gerenciamento das partes interessadas de uma organização em termos de sua habilidade em colocar esses três níveis de análise em conjunto.”32

Na opinião de Freeman (1984, p. 25), a divisão das partes interessadas em grupos específicos é uma visão extremamente simplificada uma vez que elas podem ser repartidas em várias categorias úteis menores. Ele exemplifica que uma parte interessada em particular pode causar um efeito econômico sobre a firma, ou seja, sua ação pode afetar a lucratividade, o fluxo de caixa ou o preço de sua ação no mercado; os clientes e fornecedores têm efeitos econômicos sobre um negócio. Se as matérias-primas não são de preço ou qualidade suficiente, uma indústria não será capaz de atingir os seus habituais padrões de qualidade; uma determinada parte interessada pode causar efeitos tecnológicos sobre a empresa, por permitir ou impedir que uma empresa da área de tecnologia, desenvolva novas tecnologias ou as traga do mercado; uma determinada parte interessada pode ter efeitos sociais sobre a empresa, alterando sua posição na sociedade, mudando a opinião do público sobre ela, ou de permitir ou reprimir o que a empresa é capaz de fazer com a permissão dada pela sociedade. Esses efeitos sociais, muitas vezes, se transformam em efeitos políticos sobre a empresa. As ações

\footnotetext{
31 "The basic idea is quite simple. Business can be understood as a set of relationships among groups that have a stake in the activities that make up the business. Business is about how customers, suppliers, employees, financiers (stockholders, bondholders, banks, and so on), communities and managers interact and create value. To understand a business is to know how these relationships work."

32 "We might define and organization's "Stakeholder Management Capability" in terms of its ability to put these three levels of analysis together."
} 
das partes interessadas, muitas vezes, envolvem o processo político, a fim de conseguir alguma finalidade social; finalmente, uma parte interessada pode causar efeitos gerenciais sobre a empresa, forçando mudanças nos seus sistemas e processos de gerenciamento e até mesmo no seu estilo gerencial e de valores." (FREEMAN, 1984, p. 92-93).

Dentro do aspecto de gerenciamento de relações entre a firma e as partes interessadas, Freeman (1984, p. 128) desenha um esquema de programas estratégicos a ser seguido nas seguintes linhas:

1. Os programas existentes para as partes interessadas. Esses programas são as estratégias que a empresa atualmente está adotando para gerir as relações com suas partes interessadas.

2. Novos Programas para as partes interessadas. Esses programas visam estabelecer novos relacionamentos das partes interessadas ou alterar a forma como se lida com as relações atuais com as partes interessadas.

3. Programas para aperfeiçoar a eficiência das operações em curso. Programação estratégica deve estar preocupada não só com o que a empresa pode fazer de forma diferente, mas também com a forma como pode ser mais eficiente em suas operações correntes com determinados grupos de partes interessadas.

4. Programas de apoio para relacionamentos com outras partes interessadas. Programas de apoio que são formulados para auxiliar outros gestores a alcançar seus objetivos com suas próprias partes interessadas. $^{33}$

Freeman (1984, p. 247) acrescenta que sua ênfase tem sido sobre começar a construir uma abordagem de gestão que leve em conta o ambiente externo em uma rotina sistemática. ${ }^{34}$

Para melhor analisar as partes interessadas e suas influências sobre as outras partes interessadas e sobre os propósitos da empresa, Freeman (2007, p. 8) classifica as partes interessadas em dois grupos: as partes interessadas primárias e as secundárias. A figura 2 mostra as partes interessadas classificadas como primárias e secundárias. São consideradas como primárias aquelas que possuem alta legitimidade e como secundárias aquelas que

\footnotetext{
33 "1. Existing Programs for Stakeholders. These programs are the strategies which the firm is currently undertaking to manage its stakeholder relationships.

2. New Programs for Stakeholders. These programs seek to establish new stakeholder relationships or to change the ways that current stakeholder relationships are handled.

3. Programs To Improve Efficiency of Current Operations. Strategic programming must be concerned not only with what the firm can do differently, but with how it can be more efficient in its current operations with certain stakeholder groups.

4. Support Programs for Other Stakeholder Relationships. Support programs are formulated to help other managers achieve their goals with their own stakeholder."

34 "My emphasis has been on beginning to construct an approach to management which takes the external environment into account in a systematic and routine way."
} 
podem influenciar o relacionamento da organização com as partes interessadas primárias. (FREEMAN, 2007, p. 7). ${ }^{35}$

Logo, os stakeholders primários e secundários podem ser esquematizados assim:

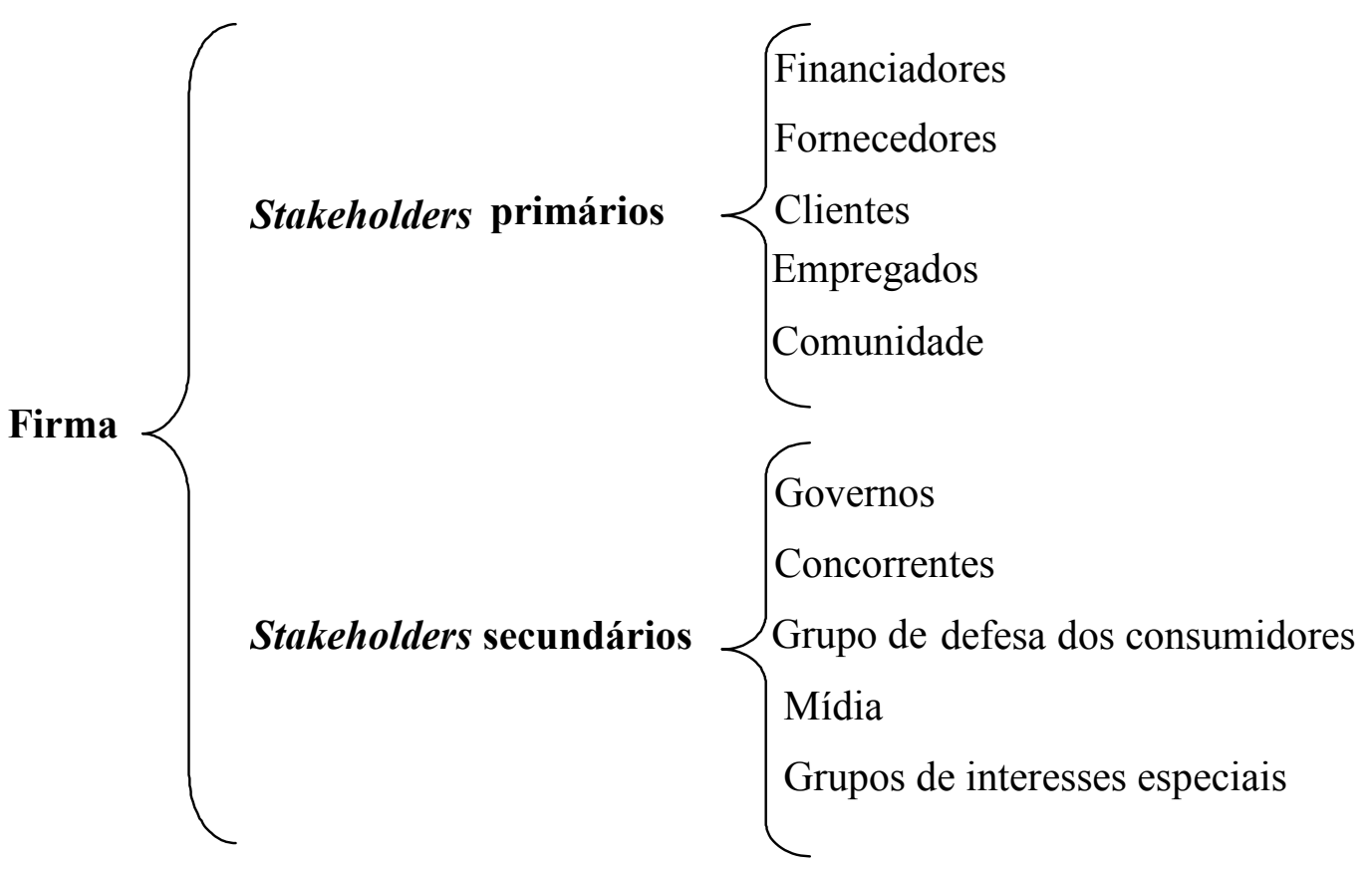

Figura 2 - Classificação dos stakeholders segundo Freeman

Freeman (2007, p. 6) complementa que

[...] nós definimos uma parte interessada como qualquer grupo ou indivíduo que pode afetar ou é afetado pela realização de um objetivo da corporação. Aqueles primeiros grupos, que chamaremos de partes interessadas primárias, define a maioria das empresas. Claramente, os administradores devem dedicar um tipo especial de atenção a esses grupos. Eles precisam entender os valores e propósitos que estejam em jogo entre os clientes, fornecedores, financiadores, comunidades e funcionários. Os interesses desses grupos contribuem de maneira importante para explicar se uma empresa foi construída para durar ou não, se pode atingir e sustentar desempenhos extraordinários. $^{36}$

\footnotetext{
35 "Each of these can influence the relationship of the corporation with the primary stakeholders."

36 "[...] we have defined a stakeholder as any group or individual who can affect or is affected by the achievement of a corporation's purpose. Those groups in the inner circle, which we will call primary stakeholders, define most businesses. Clearly, managers need to pay a special kind of attention to these groups. They need to understand the values and purposes that are at stake among customers, suppliers, financiers, communities, and employees. The interests of these groups go a long way in explaining whether or not a company is built to last, whether it can achieve and sustain extraordinary performance."
} 
$\mathrm{Na}$ análise dessa mudança de comportamento no relacionamento entre as firmas e as partes interessadas, Freeman (2007, p. 26) diz que

Em primeiro lugar, há pelo menos quatro mudanças macro que tornam as empresas mais complexas e incertas. Em segundo lugar, as relações críticas que definem um negócio - com os clientes, fornecedores, empregados, comunidades e os proprietários - tem experimentado alterações substanciais à medida que começamos o século XXI. Finalmente, a capacidade de outros grupos e indivíduos de influenciarem essas relações primárias mudou drasticamente, tornando os governos, ambientalistas, grupos de interesse, a mídia, e até mesmo grupos ilegais relevantes para as empresas. ${ }^{37}$

Essas quatro mudanças macro são:

- A Liberalização dos Mercados;

- A Liberalização das Instituições Políticas;

- O Surgimento do Ambientalismo e Outros Valores Sociais;

- A Explosão de Tecnologia da Informação. (Ibid. p. 27-29)

Sobre a liberalização de mercados, ele explica que, durante a ascensão da estrutura gerencial capitalista dominante, o mundo estava envolvido em uma guerra ideológica, na qual se situavam, por um lado, os mercados livres e, por outro, a indústria estatal e a indústria planejada pelo Estado. Por muitas razões complicadas, essa guerra acabou e os mercados livres foram declarados vencedores. ${ }^{38}$

Com relação à liberalização de instituições políticas, Freeman (2007, p. 27) diz que "Ao mesmo tempo em que os mercados se abriram e se tornaram mais globais em natureza, as instituições políticas tornaram-se mais liberalizadas e mais abertas." 39

\footnotetext{
37 "First, there are at least four macro changes that make business more complex and uncertain. Second, the critical relationships that define a business - those with customers, suppliers, employees, communities, and owners - have experienced substantial change as we begin the twenty-first century. Finally, the ability of other groups and individuals to influence these primary relationships has changed dramatically, making governments, environmentalists, interest groups, the media, and even illegal groups relevant to business."
}

\section{8 "The Liberalization of Markets}

During the rise of the dominant framework of managerial capitalism the world was engaged in an ideological war; free markets versus state-owned and state-planned industry. For many complicated reasons this war is over, and free markets have been declared the winner."

\section{9 “"The Liberalization of Political Institutions}

At the same time that markets have opened up and become more global in nature, political institutions have become more liberalized and more open." 
Ao analisar o surgimento do ambientalismo e outros valores sociais, Freeman (2007, p. 27) alerta que "Os últimos dez anos têm trazido também uma maior conscientização para o fato de que não temos sido muito bons cuidadores do planeta Terra." ${ }^{40}$

Por fim, Freeman explica "que a liberalização tanto dos mercados quanto das instituições políticas e, em certa medida, do ambientalismo e outros valores sociais, são dependentes do crescimento da tecnologia da informação." (Ibid., p. 29). ${ }^{41}$

Diante do quadro dessas quatro mudanças macro, são sintetizadas nos Quadro 2 e 3 as principais mudanças de comportamento e postura das partes interessadas primárias, que possuem elevada legitimidade diante das empresas.

Quadro 2 - Principais mudanças de relacionamento entre partes interessadas primárias e as empresas

\begin{tabular}{|c|l|}
\hline $\begin{array}{c}\text { Tipos de } \\
\text { Stakeholder }\end{array}$ & \multicolumn{1}{|c|}{$\begin{array}{c}\text { Principais mudanças de relacionamentos entre as empresas } \\
\text { e as partes interessadas }\end{array}$} \\
\hline Financiadores & $\begin{array}{l}\text { Além das preocupações financeiras, com números de lucratividades, } \\
\text { endividamento, rentabilidade, passaram a olhar os processos éticos, uma vez que } \\
\text { escândalos, como os recentes americanos, diminuem a credibilidade das } \\
\text { empresas. }\end{array}$ \\
\hline Fornecedores & $\begin{array}{l}\text { Deixaram a visão de desempenho e tomada de decisões de compra e passaram a } \\
\text { se preocupar, também, com certificação, formas de aquisição de materiais, } \\
\text { práticas ambientais etc.. }\end{array}$ \\
\hline Clientes & $\begin{array}{l}\text { Deixaram a visão tradicional entre preço e desempenho e passaram a se } \\
\text { preocupar, também, com serviços e formas de produção da empresa. }\end{array}$ \\
\hline Empregados & $\begin{array}{l}\text { Saíram da visão de apenas salários e benefícios para se preocupar, também, com } \\
\text { outras diferentes chaves de preocupações como: raça, sexo, orientação, idade, } \\
\text { minorias e cultura. }\end{array}$ \\
\hline Comunidades & $\begin{array}{l}\text { No passado, o costume de obedecer às leis, fazer donativos ou outras caridades ou } \\
\text { ajudar escolas e organizações não governamentais eram ideais. Hoje, são mais } \\
\text { complicadas. As comunidades foram ampliadas geograficamente devido ao } \\
\text { mundo virtual. Hoje preocupam-se com princípios globais de condução dos } \\
\text { negócios em lugar de preocupação com os princípios da comunidade local. }\end{array}$ \\
\hline
\end{tabular}

\section{0 "The Emergence of Environmentalism and Other Social Values}

The past ten years have also brought an increasing awareness of the fact that we have not been very good stewards of the planet Earth."

\section{1 "The Explosion of Information Technology}

Certainly the liberalization of both markets and political institutions, and to some extent environmentalism and other social values, are dependent on the growth of information technology." 
O Quadro 3, por sua vez, sintetiza as principais mudanças de relacionamento ocorridas entre as partes interessadas secundárias e as empresas. (FREEMAN, 2007, p. 37-46).

Quadro 3 - Principais mudanças de relacionamentos entre as partes interessadas secundárias e as empresas

\begin{tabular}{|c|c|}
\hline $\begin{array}{l}\text { Tipos de } \\
\text { Stakeholder }\end{array}$ & $\begin{array}{l}\text { Principais mudanças de relacionamentos entre as empresas } \\
\text { e as partes interessadas }\end{array}$ \\
\hline Governos & $\begin{array}{l}\text { Não só a relação contribuinte fisco, mas passou a incluir novas agências } \\
\text { governamentais com regulamentações específicas que afetam diretamente o } \\
\text { negócio. Decisões como antitruste, concentração de negócios, atendimentos a } \\
\text { agências reguladoras, quer em nível federal, estadual ou municipal, podem afetar } \\
\text { a natureza dos negócios. }\end{array}$ \\
\hline Concorrentes & $\begin{array}{l}\text { As regras, hoje, são diferentes. Não existe um campo local de competição. A } \\
\text { emergência da competição global faz as firmas competirem global mas também } \\
\text { localmente. }\end{array}$ \\
\hline $\begin{array}{c}\text { Grupos de defesa } \\
\text { dos } \\
\text { consumidores } \\
\end{array}$ & $\begin{array}{l}\text { Muitas companhias de sucesso têm reconhecido a importância desses } \\
\text { movimentos de consumidores; ativistas têm interferido diretamente no sucesso do } \\
\text { negócio por meio de organizações estruturadas fora da arena governamental. }\end{array}$ \\
\hline Mídia & $\begin{array}{l}\text { O relacionamento e a divulgação de informações para os meios de comunicação, } \\
\text { seja por meios de blogs com credibilidade ou outros meios, são importantes } \\
\text { aparatos para campanhas de marketing e podem ser mortais quando críticos para } \\
\text { uma companhia. }\end{array}$ \\
\hline $\begin{array}{l}\text { Grupos de } \\
\text { interesses } \\
\text { especiais } \\
\text { (Ambientalistas, } \\
\text { ONG etc.) }\end{array}$ & $\begin{array}{l}\text { Os negócios devem tornar-se tanto verde como lucrativo; produtos } \\
\text { ecologicamente correto; o conceito de sustentabilidade; selos de produção e } \\
\text { formas de elaboração e compras de matérias primas; socialmente sustentáveis. } \\
\text { Organizações não governamentais com conceitos particulares de minorias, } \\
\text { portadores de deficiências, direitos das mulheres, dentre outros, buscam interagir } \\
\text { e cobrar posições das organizações. }\end{array}$ \\
\hline
\end{tabular}

Com o objetivo de melhor gerenciar o relacionamento entre as partes interessadas entre si e com a empresa, Freeman (2007, p. 48) demonstra sua preocupação ao afirmar

A idéia é simples. Um negócio é bem sucedido à medida que cria valor e satisfaz as principais partes interessadas continuamente e ao longo do tempo. É preciso estar ciente de potenciais influências de grupos que podem estar em contradição com a sua finalidade. No cerne do processo da criação de valor que é negócio, encontra-se uma profunda preocupação com os interesses e relacionamentos das partes interessadas. ${ }^{42}$

\footnotetext{
42 "The idea is a simple one. A business is successful insofar as it creates value for and satisfies key stakeholders continually over time. It must be aware of potential influences from groups that may be at odds with its purpose. At the very heart of the process of value creation that is business, we find a profound concern with stakeholders interests and relationships."
} 
Diante dessa preocupação com os interesses e relacionamentos das partes interessadas, Freeman (2007, p. 60) estabelece dez princípios para gerenciamento dessas partes, sintetizados no Quadro $4 .^{43}$

Quadro 4 - Dez princípios para gerenciamento de relacionamentos com as partes interessadas

\begin{tabular}{|c|l|}
\hline Número & \multicolumn{1}{|c|}{ Princípios } \\
\hline 1. & Os interesses das partes interessadas precisam caminhar juntos ao longo do tempo. \\
\hline 2. & $\begin{array}{l}\text { Precisamos ter uma filosofia de voluntarismo - para envolver as partes interessadas e } \\
\text { gerenciar os relacionamentos entre elas, em vez de deixá-lo nas mãos do governo. }\end{array}$ \\
\hline $\mathbf{3 .}$ & $\begin{array}{l}\text { Precisamos encontrar soluções para problemas que satisfaçam simultaneamente } \\
\text { múltiplas partes interessadas. }\end{array}$ \\
\hline 4. & $\begin{array}{l}\text { Tudo o que fazemos serve às partes interessadas. Nós nunca negociamos os interesses de } \\
\text { uma das partes em detrimento da outra ao longo do tempo. }\end{array}$ \\
\hline 5. & $\begin{array}{l}\text { Agimos com o propósito que garante o nosso compromisso com as partes interessadas. } \\
\text { Agimos com a aspiração no sentido de realizar nossos sonhos e os delas. }\end{array}$ \\
\hline $\mathbf{6 .}$ & $\begin{array}{l}\text { Precisamos de comunicação e diálogo intensivos com os interessados - não apenas } \\
\text { aqueles que são amigáveis. }\end{array}$ \\
\hline 7. & $\begin{array}{l}\text { Partes interessadas são constituídas de pessoas reais, com nomes, rostos e filhos. Elas são } \\
\text { complexas. }\end{array}$ \\
\hline 8. & Precisamos generalizar a abordagem do marketing. \\
\hline 9. & Comprometemo-nos com as partes interessadas tanto primárias como secundárias. \\
\hline 10. & $\begin{array}{l}\text { Constantemente, monitoramos e redesenhamos processos para torná-los melhores para } \\
\text { servir as nossas partes interessadas. }\end{array}$ \\
\hline
\end{tabular}

Fonte: Freeman et al. (2007, p. 60)

Por fim, o Quadro 5, a seguir, mostra o resultado de uma pesquisa realizada por Freeman (2007, p. 107) sobre a importância dada pelas partes interessadas a alguns itens.

43 "Ten Principles of Managing for Stakeholders:

1. Stakeholders interests need to go together over time

2. We need to have a philosophy of voluntarism - to engage stakeholders and manage relationship ourselves, rather than leaving it go government

3. We need to find solutions to issues that satisfy multiple stakeholders simultaneously

4. Everything that we do serves stakeholders. We never trade off the interests of one versus the other continuously over time

5. We act with purpose that fulfills our commitment to stakeholders. We act with aspiration towards fulfilling our dreams and theirs.

6. We need intensive communication and dialogue with stakeholders - not just those who are friendly

7. Stakeholders consist of real people with names and faces and children. They are complex.

8. We need to generalize the marketing approach.

9. We engage with both primary and secondary stakeholders

10. We constantly monitor and redesign processes to make them better serve our stakeholders. 
Quadro 5 - Níveis de importância dados pelas partes interessadas a alguns itens

\begin{tabular}{|l|l|l|l|l|l|}
\hline \multicolumn{1}{|l|}{ Parte Interessada } & Empregados & Clientes & Governos & Comunidade & Proprietários \\
\hline Segurança do produto & 3 & 1 & 1 & 1 & 3 \\
\hline $\begin{array}{l}\text { Integridade dos relatórios } \\
\text { financeiros }\end{array}$ & $\mathbf{1}$ & 3 & $\mathbf{1}$ & 3 & $\mathbf{1}$ \\
\hline $\begin{array}{l}\text { Novos produtos e serviços } \\
\text { Retornos financeiros }\end{array}$ & 3 & 1 & 5 & 3 & 3 \\
\hline
\end{tabular}

Fonte: Freeman et al. (2007, p. 107). (Grifo nosso).

em que

1 = importância crítica para a parte interessada;

3 = alguma importância para a parte interessada e

5 = não muito importante para a parte interessada.

Como se observa no Quadro 5, as partes interessadas Empregados, Governos e Proprietários declararam ser de importância crítica para eles a integridade dos relatórios financeiros. E, nesse aspecto, acredita-se que seria de maior importância ainda se essas partes interessadas tivessem consciência do valor da riqueza criada pelo negócio e qual a parte que cada uma recebeu como fatia dessa riqueza. É, nesse contexto, que a Demonstração de Valor Adicionado foi escolhida como relatório financeiro a dar suporte de estudo à questão de pesquisa deste trabalho.

\subsection{A Demonstração de Valor Adicionado (DVA)}

O interesse em identificar, estudar, mensurar e analisar os efeitos dos incentivos fiscais na criação e distribuição de riqueza pelo modelo industrial Zona Franca de Manaus, leva à busca de um instrumento técnico que auxilie na sua realização. Como ferramental técnico para a realização dessa tarefa foi escolhida a Demonstração de Valor Adicionado (DVA). Essa demonstração permite às partes interessadas tomarem conhecimento sobre como as empresas estão criando riqueza, seja para seus colaboradores internos, seja para a sociedade, por meio 
de aluguéis, juros e tributos, ou para seus proprietários, por meio dos juros sobre o capital próprio, dividendos ou retenções de lucros.

Entretanto, antes de iniciar uma abordagem técnica sobre essa demonstração, torna-se necessária uma breve contextualização histórica sobre sua origem e importância. Para isso, este trabalho parte do conceito de Balanço Social para alcançar esse fim.

Segundo Tinoco (2001), a partir da segunda metade do século XX, os grupos representados pelos trabalhadores e seus sindicatos começaram a fazer exigências às organizações com $o$ objetivo de obter informações que pudessem ser utilizadas nas bases de negociações das suas relações econômicas e sociais. Ele, assim, confirma

\begin{abstract}
A partir da década de 60 do século XX, os trabalhadores, especialmente na Europa e nos Estados Unidos da América, passaram a fazer exigências às organizações no sentido de obterem informações relativas ao seu desempenho econômico e social, ampliando a informação que as organizações forneciam, incorporando as sociais (especialmente aquelas relativas ao emprego), tendo em vista a discussão da responsabilidade social, dando assim origem à implantação do Balanço Social, em França, a partir de 1977, que evidenciava basicamente os recursos humanos.
\end{abstract}

A Europa, com a preocupação voltada para o atendimento das reivindicações dos movimentos sociais que demandavam das empresas informações sobre projetos sociais, impactos e responsabilidades ambientais e dados sobre a composição da mão de obra, como volume, remuneração e encargos sociais, condições de trabalho e treinamento, dentre outras, dá origem ao Balanço Social.

Nos últimos anos, tem-se observado cada vez mais, numa dimensão crescente, a elaboração de uma nova demonstração, a partir da contabilidade, denominada de Balanço Social. Nessa direção, o Livro Verde da Comissão das Comunidades Européias, em 18 de julho de 2001, estabeleceu que:

\begin{abstract}
A responsabilidade social das empresas é a integração voluntária das preocupações sociais e ecológicas das empresas às suas atividades comerciais e suas relações com todas as suas partes intervenientes internas e externas (acionistas, pessoal, clientes, fornecedores e parceiros, sociedade...) e a fim de satisfazer plenamente as obrigações jurídicas aplicáveis e investir no capital humano e no meio ambiente. (IGALENS; JORAS, 2002, p. 15). ${ }^{44}$
\end{abstract}

\footnotetext{
44 "La responsabilité sociale des enterprises (RSE) est lintégration volontaire des préoccupations sociales et écologiques des enterprises à leurs activités commerciales et leurs relations avec toutes leurs parties prenantes internes et externes, (actionnaires, personnels, clients, fournisseurs et partenaires, collectivités humaines...) et ce afin de satisfaire pleinement aux obligations juridiques applicables et investir dans le capital humain et lénvironnement".
} 
Mathews $(1993,209)$ diz que

\begin{abstract}
A abordagem da teoria de permissão social fornece uma justificativa para o desenvolvimento de evidenciações de contabilidade social que é parte da estrutura societária e organizacional corrente. Essa abordagem busca modificar e consertar nossos sistemas atuais de controle público e privado e práticas de divulgação de relatórios associados. Não busca substituí-los da maneira defendida pelos adeptos do paradigma radical. Apóia a evolução e não a revolução. Esse apoio parcial ao status quo é tanto uma força como uma fraqueza da abordagem da teoria da permissão social. É uma força porque um grande número de grupos na sociedade pode aceitar essa posição numa dimensão maior ou menor. Esses incluem gerentes, acionistas, muitos empregados e clientes. É uma fraqueza porque as distribuições de riqueza existentes são dadas como certas e as relações de poder são vistas como não problemáticas. Aqueles grupos não envolvidos na sociedade como empregados ou clientes (tais como os muito pobres) tendem a ser ignorados. ${ }^{45}$
\end{abstract}

O Balanço Social, na forma como proposta, tem sua origem na contabilidade das empresas, pois, normalmente, é por meio delas que as empresas divulgam os seus desempenhos econômicos e financeiros aos seus diferentes usuários. Entretanto, segundo Tinoco (1993, p. 4), essas divulgações são insuficientes para apresentar o tipo de informação necessária para cada tipo de agente, deixando, em segundo plano, usuários que, direta ou indiretamente contribuem para a geração da riqueza de um determinado empreendimento. $\mathrm{Na}$ sua visão, a importância do Balanço Social é devida ao fato de que o

Balanço Social é um instrumento de gestão e de informação que visa reportar, de forma mais transparente possível, informações econômicas e sociais, do desempenho das entidades, aos mais diferenciados usuários, dentre estes os trabalhadores. (Ibid., p. 4).

Nessa mesma linha de raciocínio, há de se ressaltar a defesa de Tinoco (1993, p. 4) sobre o Balanço Social quando afirma que "um conceito modernamente aceito diz que a existência das empresas não pode se justificar exclusivamente pela capacidade que elas demonstrem de gerar lucros aos seus proprietários. Desse tipo de visão, derivam programas de incentivos e motivação aos empregados [...], dentre outras." Como exemplo de países que divulgam o Balanço Social, Tinoco (1993, p. 4) cita a França por caracterizar-se pela existência de uma lei que obriga toda e qualquer entidade com mais de 300 trabalhadores a divulgá-lo.

\footnotetext{
45 "The social permission theory approach provides a justification for developing social accounting disclosures which is part of the current organizational and societal structure. This approach seeks to modify and amend our present systems of private and public control and associated reporting practices. It does not seek to replace them in the manner advocated by adherents of the radical paradigm. It supports evolution rather than revolution. This partial support for the status quo is both a strength and a weakness of the social permission theory approach. It is a strength because a large number of groups in society can accept this position to a greater or lesser extent. These include managers, shareholders, many employees and customers. It is a weakness because existing wealth endowments are taken as given and power relationships are viewed as unproblematic. Those groups not involved in society as employees or customers (such as very poor) tend to be ignored."
} 
O Balanço Social, como conjunto de relatórios que pretende demonstrar as informações contábeis, econômicas, financeiras, sociais e ambientais aos mais diversos grupos de interesses, é composto de quatro grandes demonstrações, cada uma diretamente correlacionada à uma área específica, a saber:

- Balanço Ambiental;

- Demonstração de Valor Adicionado;

- Demonstração de Melhorias à Comunidade e

- Demonstração de Recursos Humanos.

Discute-se sobre a necessidade de informações contábeis, econômicas e sociais dos diversos agentes econômicos, como volume de carga tributária, valor destinado ao pagamento de mão de obra, dentre outras, e que não são atendidas pelas demonstrações contábeis tradicionais. A contabilidade social é uma das áreas que mais necessita de pesquisas e vem recebendo cada vez mais atenção da comunidade acadêmica. O importante fator que pode ser atribuído ao atual estado da arte é a inexistência de um arcabouço teórico consolidado que permita definir, padronizar e quantificar a sua aplicação.

Tanto a teoria da legitimidade como a teoria das partes interessadas - stakeholders - aceitam que as companhias podem ter duas razões para publicar informações sociais. A divulgação pode ser usada para demonstrar que a companhia tem atendido às suas obrigações morais e éticas para com a sociedade ou para evitar críticas e gerenciar expectativas das partes interessadas, sem necessariamente alterar seu comportamento atual.

A ideia da contabilidade social, de que a empresa tem compromissos com a sociedade em que atua e que deve apresentar o quanto de retorno ela proporciona aos diversos grupos que compõem a sociedade, coaduna com Tinoco (2001), ao constatar que a entidade empresa "aparece cada vez mais como sendo o resultado de uma coalizão entre os diferentes grupos sociais". Na realidade, a empresa não sobrevive como um sistema fechado, ela interage com o mundo exterior e representa uma convergência de interesses diversos. 
Mathews (1993, p. 10) diz que

[...] existe uma grande quantidade de argumentos que podem ser colocados "a priori" em apoio a pelo menos alguma responsabilidade social (e assim contabilidade socialmente responsável) pelas empresas em um sistema de mercado relativamente livre. São eles:

1. Um mercado livre será mais eficiente se mais informação estiver disponível para os participantes;

2. Pesquisas empíricas têm demonstrado que a medida de responsabilidade social pela administração pode estar correlacionada com maiores lucros empresariais;

3. Há evidências de que os preços das ações podem ser influenciados pelas evidenciações de responsabilidade social das empresas. ${ }^{46}$

Isso leva a concordar com a afirmativa de Tinoco (2001), quando diz que "a noção de responsabilidade social nos remete para a atitude da empresa - em face das exigências da sociedade, em consequência de suas atividades - a avaliação e compensação dos custos sociais que a mesma gera e ampliação do campo de seus objetivos.” Ele constatou ainda que

\begin{abstract}
Mais recentemente, a sociedade, sujeito e objeto das atividades humanas, vem propugnando por maior abertura, quanto à revelação de informações econômicas, financeiras, sociais e ambientais, que justifiquem a razão de ser das entidades, como sujeitos públicos, inserindo-se, portanto, no contexto dos usuários do Balanço Social. As entidades consomem recursos naturais, renováveis ou não, direta ou indiretamente, que constituem parte integrante do patrimônio da humanidade, utilizam recursos humanos, físicos e tecnológicos, que pertencem a pessoas e, portanto à sociedade. As organizações vivem em função da sociedade, devendo, em troca, revelar informações de como usam eficiente e eficazmente esses recursos.
\end{abstract}

\title{
Martins e Ribeiro (1993) complementam que
}

pela pressão dos diversos segmentos que a cercam (sociedade civil, governo, clientes e fornecedores), as empresas viram-se obrigadas a incorporar aos objetivos de obtenção de lucros a responsabilidade social, visto que a continuidade de suas atividades depende de sua aceitação pela comunidade como um todo e a referida responsabilidade social abrange o bem estar da população na sua integridade.

\footnotetext{
46 "[...] there are a number of arguments which may be advanced in support of at least some social responsibility (and hence socially responsible accounting) by corporations in a relatively free market system. These are:

1. A free market will be more efficient if more information is available to participants;

2. Empirical research has demonstrated that a measure of social responsibility by management may correlate with higher corporate income;

3. There is some evidence that share prices may be influenced by the social responsibility disclosures of corporations."
} 
Os principais grupos de usuários, e seus respectivos interesses, do Balanço Social podem ser sintetizados como:

a) Colaboradores internos e seus sindicatos: grupo formado pelos empregados e pelos seus sindicatos que se interessam pela remuneração da força de trabalho, seus benefícios e pela manutenção dos seus postos;

b) Colaboradores externos: grupo composto por emprestadores e fornecedores que se interessam pela remuneração dos recursos emprestados e pela capacidade no cumprimento dos compromissos comerciais firmados;

c) Proprietários: grupo formado pelos acionistas que buscam a remuneração do capital investido na entidade;

d) Clientes: grupo que se interessa pela capacidade que a empresa possui em continuar uma relação comercial estável e duradoura de fornecimento de seus produtos;

e) Governos: grupo formado pelas três esferas de governo: federal, estadual e municipal. Interessados, principalmente, na capacidade contributiva que a entidade possui, tomando-se a remuneração pela estrutura social, política e econômica que gera condições de operações no meio ambiente, para fazer frente às suas necessidades de recursos indispensáveis ao cumprimento de suas obrigações sociais e

f) Comunidades locais e regionais: grupo que busca o retorno social, incluíndo o mais amplo conceito de retorno, desde a capacidade de criação de empregos numa determinada região à emissão de poluentes nesse mesmo ambiente.

Nesse contexto, o Balanço Social apresenta a função de apresentar à sociedade uma série de informações de caráter econômico, financeiro e social de interesse dos grupos interessados da forma como eles gostariam de ter conhecimento e tem, por um dos seus objetivos, possibilitar a transparência e comunicar informações que satisfaçam às necessidades de quem dele precisa. Parte dessas informações pode ser disponibilizada por meio da Demonstração de Valor Adicionado (DVA), que se utiliza de elementos da Contabilidade Nacional.

Mathews (1993, p. 95) mostra que

As demonstrações de valor adicionado têm lugar na literatura sobre contabilidade socialmente responsável (SRA) embora elas sejam compostas de dados financeiros que são derivados, em sua maioria, de contas financeiras convencionais. A demonstração de valor adicionado foi defendida 
no Relatório Empresarial (ASSC, 1975) e no Relatório Oficial do governo do Reino Unido. (HMSO, 1977). ${ }^{47}$

Para o objetivo da presente pesquisa, a análise dos conceitos sobre as variáveis que melhor explicam a formação e distribuição da riqueza pela Zona Franca de Manaus possui uma relação direta com a Demonstração de Valor Adicionado (DVA), por ser um relatório que revela, de forma clara e consistente, a criação de riqueza pelas empresas industriais instaladas naquela região e a sua distribuição entre os agentes que contribuíram para a sua geração.

Santos (2003) ressalta que "numa época em que se tem a globalização como irreversível, a DVA começa a se materializar como uma forma de visualização dos benefícios (malefícios) a respeito de participação das empresas no contexto social em que estão inseridas."

Na constatação de Martins (1997), “a demonstração de resultado é uma visão particular de apenas um dos interessados na empresa, os seus proprietários." Por outro lado, "a demonstração do valor adicionado é de uma visão muito mais geral, dando a mesma importância a todos os fatores de produção: o trabalho, os demais capitais na forma de crédito e também o governo". Nessa mesma linha de raciocínio, Santos e Silva (2003) complementam que "a DVA está voltada para todos os agentes econômicos interessados na empresa, tais como governos, acionistas, financiadores, fornecedores, empregados e clientes enquanto a DRE interessa muito mais aos próprios acionistas."

A Demonstração de Valor Adicionado (DVA) demonstra a geração de valor produzido pela própria empresa, por meio das suas próprias operações e a distribuição desse valor aos diversos componentes econômicos que participaram da sua formação. Segundo Santos (2003), essa demonstração apresenta "uma função muito importante porque fornece aos usuários a informação sobre a riqueza criada e a forma como esta foi distribuída."

O valor adicionado foi, também, definido na literatura por Ruggles e Ruggles (1965), apud Van Staden (2002), como

O valor adicionado por uma firma, isto é, o valor criado pelas atividades da firma e seus empregados pode ser medido pela diferença entre o valor de mercado dos produtos que foram

\footnotetext{
47 "Value added statements have a place in the SRA literature, although they are composed of financial data that is derived, for the most part, from conventional financial accounts. Value added statements were advocated in The Corporate Report (ASSC, 1975) and the UK Government Green Paper (HMSO, 1977)."
} 
acabados pela firma e o custo desses produtos e materiais comprados de outros produtores. Essa medida excluirá a contribuição feita por outros produtores para o total do valor da produção da firma, de forma que é essencialmente igual ao valor de mercado criado por essa firma.

Belkaoui (1992, p. 9-15), em seu livro "Value Added Reporting - Lessons for the United States", apresenta as vantagens da divulgação do valor adicionado e afirma que elas se originam, essencialmente, do âmbito muldimensional da técnica, quando comparados com o modelo convencional de relatórios financeiros de uma empresa. Algumas dessas vantagens mais citadas são:

- A divulgação do valor adicionado gera um bom clima organizacional para os trabalhadores, ao destacar sua importância para o resultado final da empresa.

- A divulgação do valor adicionado pode fornecer uma maneira mais prática de introduzir aumentos de bônus de produtividade e relacionar recompensas às mudanças nos montantes de valor adicionado.

- Taxas baseadas em valor adicionado podem agir como bons sinais preditivos e de diagnóstico.

- A divulgação do valor adicionado é mais congruente com os conceitos utilizados para mensurar a receita nacional e pode criar uma relação útil com os bancos de dados macroeconômicos e técnicas utilizadas pelos economistas.

- A divulgação do valor adicionado pode agir como uma boa medida do tamanho e importância das empresas.

- $\quad$ A divulgação do valor adicionado pode ser útil para o grupo de empregados, uma vez que poderia afetar as suas aspirações e aquelas dos seus representantes numa negociação.

- A divulgação do valor adicionado pode ser útil para os investidores.

- $\mathrm{O}$ valor adicionado aparece como uma ferramenta útil para prever lucros, retornos esperados e o risco total associado a títulos.

- A divulgação do valor adicionado pode ser útil aos empregados por revelar a sua parcela do valor adicionado e sinalizar a extensão de sua importância para a administração.

- A divulgação do valor adicionado proporciona uma melhor imagem das políticas de reinvestimentos da empresa por divulgar separadamente os fundos gerados internamente para substituir e separar os ativos fixos. 
- A inclusão de uma demonstração de valor adicionado local nos relatórios anuais do país anfitrião das multinacionais forneceria informações para analisar as contribuições dessas empresas para o processo de desenvolvimento econômico nacional.

- Valor adicionado líquido é um índice de desempenho melhor do que o lucro líquido, especialmente nos casos em que as técnicas contábeis arbitrárias e incorrigíveis resultam no reconhecimento de perda contábil em vez de lucro contábil. ${ }^{48}$

Por outro lado, entre as desvantagens, ele apresenta as seguintes: ${ }^{49}$

- A divulgação do valor adicionado baseia-se na premissa errônea de que uma empresa é uma equipe de grupos que colaboram entre si.

48 "The advantages of value added reporting stem basically from the multidimensional scope of the technique when compared to the conventional mode of reporting the financial affairs of a going concern. Some of the most cited advantages follow:

- Value added reporting generates a good organizational climate for workers by highlighting their importance to the final results of the firm.

- Value added reporting may provide a more practical way of introducing productivity bonus increases and link rewards to changes in the value added amounts.

- Value added-based ratios may act as good diagnostic and predictive cues.

- Value added reporting is more congruent with the concepts used to measure national income and may create a useful link to the macroeconomic databases and techniques used by economists.

- Value added reporting may act as a good measure of the size and importance of companies.

- Value added reporting may be useful to the employee group because it could affect its aspirations and those of its negotiating representatives.

- Value added reporting may be useful to equity investors.

- Value added appears to offer a useful tool of predicting earnings, expected returns, and total risk associated with securities.

- Value added reporting may be useful to employees by revealing their share of the value added and signaling the extent of their importance to management.

- Value added reporting offers a better picture of the firm's reinvestment policies by disclosing separately the funds generated internally to replace and separate fixed assets.

- The inclusion of a local value added statement in the host-country annual reports of multinationals would provide information to analyze the contributions of these firms to the process of national economic development.

- Net value-added is a better index of performance than net profit, especially in cases where arbitrary and incorrigible accounting techniques result in the recognition of an accounting loss rather than accounting profit."

49 "Among the disadvantages:

- Value added reporting relies on the erroneous assumption that a company is a team of cooperating groups.

- The value added statement can lead to confusion, especially in cases where the value added is increasing while earnings are decreasing.

- The inclusion of the value added statement may lead management to seek wrongly to maximize the firm's value added, an unwise objective that has already been advocated in some publications.

- The naïve approach to the interpretation of a firm's value added may lead to the following five fallacies:

$\checkmark$ Increasing value added must increase profit...

$\checkmark$ Increasing value added per unit of labour must benefit shareholders...

$\checkmark$ It is possible to identify in advance an equitable distribution of changes in value added...

$\checkmark$ A relatively high value added per unit of labour represents a superior economic performance...

$\checkmark$ A labour force taking a high proportion of value added does not deserve even higher wages." 
- A demonstração de valor adicionado pode levar à confusão, especialmente nos casos em que o valor adicionado aumenta, enquanto os ganhos diminuem.

- A inclusão da demonstração de valor adicionado pode conduzir, indevidamente, a administração a procurar maximizar o valor adicionado da empresa, um objetivo insensato que já foi defendido em algumas publicações.

- A abordagem ingênua na interpretação de um valor adicionado da empresa pode levar às seguintes cinco falácias:

$\checkmark$ Aumentar o valor adicionado deve aumentar o lucro [...]

$\checkmark$ Aumentar o valor adicionado por unidade de trabalho deve beneficiar acionistas[...]

$\checkmark$ É possível identificar, previamente, uma distribuição equitativa das variações no valor adicionado $[\ldots]$

$\checkmark$ O valor adicionado por unidade de trabalho relativamente elevado representa um desempenho econômico superior [...]

$\checkmark$ A força de trabalho que tem uma elevada proporção de valor adicionado, não merece salários ainda mais elevados. (RUTHERFORD, 1981, p. 31-33)

Van Staden (2002) realiza diversos estudos sobre a divulgação da Demonstração de Valor Adicionado no mundo, mais especificamente na África do Sul, por perceber que mais de cinquenta por cento das companhias abertas daquele país publicavam, de forma voluntária, essa demonstração. Ele diz buscar uma explicação plausível para o alto nível sustentado de publicações, que, na opinião dele, estava restrita à África do Sul. Embora seu estudo tenha sido voltado para o campo mundial, o número de Demonstrações de Valor Adicionado divulgadas no Brasil não é desprezível ao ponto de não ser destacado no referido estudo, ainda mais por apresentar o caráter de voluntariedade até o ano de 2007.

O número de DVAs publicadas no Brasil é fruto do trabalho da Comissão de Valores Mobiliários (CVM), que vem incentivando sua elaboração e publicação desde o ano de 2000. Martins (1997) constata que "várias empresas têm divulgado essa demonstração de forma voluntária já há vários anos." Essa demonstração deixa de ser voluntária e, com o advento da Lei n. 11.638 de 28 de dezembro de 2007, torna-se obrigatória para as companhias abertas, a partir do exercício de 2008. 
A Tabela 7 mostra o número crescente de demonstrações de valor adicionadas publicadas no Brasil, no período de 1997 a 2007. Observa-se que no início do período pesquisado, 1997, o número era de 44, alcançando a marca de 193, em 2007.

Tabela 7 - Número de DVAs publicadas no Brasil 1997 - 2007

\begin{tabular}{c|c}
\hline Ano & Quantidade \\
\hline 1997 & 44 \\
1998 & 46 \\
1999 & 74 \\
2000 & 87 \\
2001 & 96 \\
2002 & 104 \\
2003 & 112 \\
2004 & 142 \\
2005 & 180 \\
2006 & 190 \\
2007 & 193 \\
\hline
\end{tabular}

Fonte: Fipecafi. Banco de Dados Melhores e Maiores

No Gráfico 3 estão plotadas as ocorrências, ano a ano, de publicações da Demonstração de Valor Adicionado no Brasil, no período de 1997 a 2007. Verifica-se um crescimento progressivo, merecendo destaque os crescimentos de 2003 para 2004 e de 2004 para 2005, nos quais se observam as maiores inclinações positivas da reta.

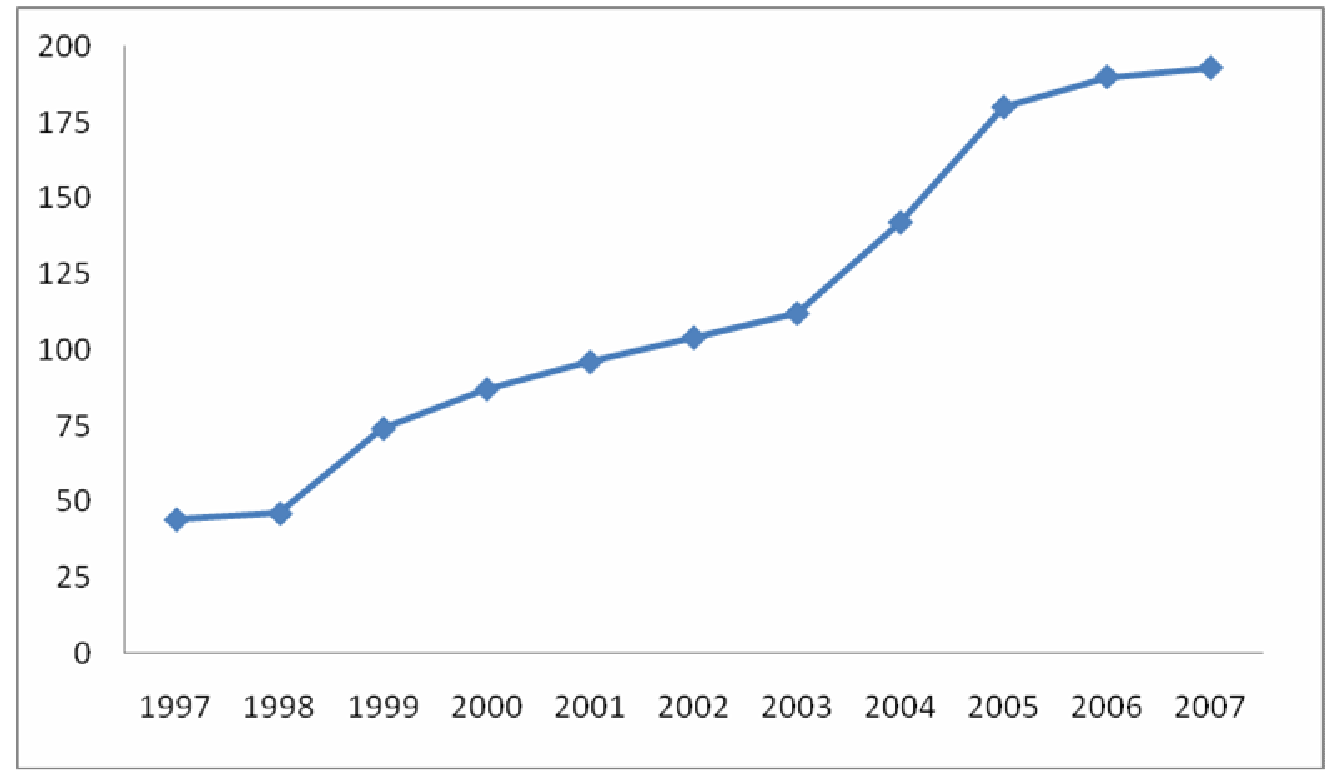

Gráfico 3 - Evolução do número de DVAs publicadas no Brasil - 1997-2007

Fonte: Fipecafi. Melhores e Maiores 
Santos (2005, p. 3), ao analisar que a DVA é uma demonstração que veio para ficar, faz uma comparação do crescimento das DVAs publicadas, apontando que

Em 1997, primeiro ano em que a DVA foi utilizada no referido cálculo de excelência profissional, foram 44 as empresas que publicaram essa demonstração. Em 2004, esse número subiu para 138, com o aumento expressivo de mais de $210 \%$.

Nas palavras de Van Staden (2002), diversas inconsistências são encontradas tanto no cálculo quanto na apresentação do valor adicionado na DVA. Ele elenca as principais áreas de inconsistências, sem esgotá-las, como as seguintes:

- o tratamento da depreciação resultante no valor adicionado bruto e líquido;

- o tratamento dos pagamentos dos tributos (competência/caixa), benefícios extras e outros benefícios na parcela dos empregados de valor adicionado;

- o tempo de reconhecimento do valor adicionado: produção ou vendas;

- o tratamento dos tributos, tais como Value Added Tax (VAT) e imposto diferido e

- o tratamento de itens não operacionais.

É ponto pacífico entre os defensores da divulgação da Demonstração de Valor Adicionado que não se trata de um relatório completo e sim, um relatório complementar no qual podem ser observadas informações não evidenciadas pelos relatórios financeiros tradicionais. Segundo Martins (1997, p. 3),

a demonstração do valor adicionado trata de uma forma diferente de mostrar o resultado da empresa. Em vez de se preocupar apenas com o resultado do capital próprio, preocupa-se também com o resultado da mão-de-obra, como dos capitais de terceiros e com a parcela levada pelo governo.

Diante dessa constatação, pode-se afirmar que a DVA permite às empresas, dentre outras informações, verificar a carga tributária a que está submetida e quanto da riqueza gerada está sendo destinada às outras partes beneficiárias: empregados, sociedade e proprietários.

Nessa direção, Soujanen (1954) vê a companhia como um centro tomador de decisões em que as que afetam várias partes interessadas são tomadas. Logo, a DVA seria considerada como um relatório que reconhece a importância de outras partes interessadas para a organização. Burchell et al. (1985) confirmam isso ao indicar que "o valor adicionado era visto como um 
critério de desempenho que coloca os empregados em condições de igualdade com outros interesses na empresa."

Van Staden (2002) afirma que “A Contabilidade não é neutra e os relatórios produzidos pelos contadores criam uma realidade que servem às estruturas de poder existentes." Nem poderia, principalmente porque esse relatório - DVA - pode ser usado para mudar percepções sobre a organização. Ele apresenta uma organização que não é aparentemente guiada por motivos de lucros, mas pelo bem da organização assim como dos participantes. Ele acrescenta que "a DVA é usada, direta ou indiretamente, na África do Sul para mudar as percepções sobre responsabilidade social das companhias num esforço de legitimá-las e suas atividades numa sociedade de mudanças."

A teoria positiva da contabilidade foi usada, no passado, para explicar porque a administração publicaria mais informação do que a requerida pelos estatutos. Em termos de teoria positiva da contabilidade, evidenciações voluntárias se justificarão somente se elas puderem ser usadas para diminuir os custos de agência. O uso da DVA pode não reduzir os custos de agência, mas poderá impactar nos custos políticos da organização.

Ao definir custos políticos, Watts e Zimmerman (1978) consideram as ações tomadas pelas organizações para evitar atenção adversa que altos lucros trazem. Essas ações "tais como campanhas de responsabilidade social na mídia [...]" (p.115) são feitas para reduzir a probabilidade de ações políticas adversas e custos esperados, que incluem "os custos dos sindicatos impostos por meio de demandas aumentadas geradas pelo alto valor dos lucros reportados." (p.115). De acordo com a hipótese de custos políticos, grandes firmas são, provavelmente, as que mais usam escolhas contábeis que reduzem lucros reportados (Id., 1990) ou fazem outras evidenciações para reduzir custos políticos. Isso é feito com o intuito de prevenir distribuição de riqueza da firma e é, portanto, no interesse da administração e dos proprietários.

Embora a teoria de custos políticos seja, frequentemente, associada com a adoção de técnicas contábeis para a redução de lucros, Deegan (2002) relata sobre pesquisas que têm assumido que evidenciações sociais voluntárias nos relatórios anuais da organização podem ser explicadas como um esforço para reduzir custos políticos das entidades evidenciadas. A DVA pode, portanto, ser usada para reduzir custos políticos impostos sobre a companhia pelos 
parceiros comerciais e governos ao indicar que, por causa de a companhia ter obtido altos lucros, os empregados receberam uma grande fatia do valor adicionado pela companhia.

Cosenza (2003) esclarece que:

O cálculo do valor adicionado apresenta algumas divergências em função da diferença de enfoque utilizado para seu conhecimento pelos Contadores e pelos Economistas. Na área econômica, o conceito de riqueza criada é obtido a partir da produção, ao passo que, contabilmente, é tomado como base o montante das vendas.

Com a utilização do processo de exclusão de dupla contagem, o somatório dos valores obtidos nas Demonstrações de Valor Adicionado (DVA), apresentadas pelas unidades produtivas, se apresenta como uma forma aproximada de cálculo do Produto Interno Bruto do país, sem deixar de destacar o fato de que o conceito, aqui utilizado pela Contabilidade, mostra a limitação em considerar as unidades vendidas. Logo, o Valor Adicionado, como conceito integrante da Contabilidade Nacional, faz De Luca (1998) concluir que "O Produto Interno Bruto representa a soma dos valores adicionados produzidos por todos os agentes econômicos do país, ou seja, representa a riqueza da nação.” Santos (1999) complementa

a superioridade da metodologia contábil se materializa através de práticas contábeis consistentes e da utilização de valores reais. Mesmo aqueles valores passíveis de estimativa contábil são obtidos mediante provisionamentos que serão sempre confrontados e ajustados aos valores reais, em algum momento futuro, além de estarem, permanentemente, submetidos ao processo de auditoria, tanto externa como interna.

Na mesma linha de raciocínio, Santos (2003) acrescenta:

o valor adicionado representa o incremento de valor que se atribui a um bem durante o processo produtivo. Assim, poder-se-ia concluir que as empresas, ao exercerem suas atividades, utilizandose de bens e serviços que são adquiridos de terceiros, aplicando seus capitais, através da utilização de seus equipamentos, e o trabalho de seus empregados, estarão adicionando valor aos novos produtos que serão colocados no mercado.

De fato, a Demonstração de Valor Adicionado (DVA) vem ganhando destaque dentre os componentes do Balanço Social por apresentar as seguintes características:

a) Demonstra a riqueza criada pela entidade e sua destinação, como: remuneração dos seus empregados; geração de tributos aos governos federal, estadual e municipal; remuneração por utilização do capital de terceiros, sob a forma de despesas financeiras; 
remuneração dos acionistas, sob a forma de juros sobre o capital próprio, distribuição de dividendos e retenção de lucros;

b) Demonstra a geração de riqueza e seus possíveis efeitos sobre a sociedade na qual a empresa atua e

c) Cria uma possibilidade infinita de análises comparativas temporais e setoriais que podem fornecer subsídios para a definição e implementação de políticas de planejamento econômico e social.

Vale salientar a afirmação de De Luca (1998): “A demonstração do valor adicionado surgiu para evidenciar o quanto de valor a empresa adiciona aos insumos que adquire, bem como sua distribuição aos elementos que contribuíram para essa adição, atendendo a esses diferentes tipos de usuários." Assim, "a análise do valor adicionado pode servir como uma ótima fonte complementar de explicação para os aspectos relacionados com a eficiência e a produtividade alcançada por uma empresa, dada a sua interrelação com a contribuição proporcionada por cada fator produtivo ao processo de produção.” (CONSENZA, 2003, p. 20).

Com o reconhecimento de que sua utilização possa ser a mais abrangente possível, pode-se resumir a importância da DVA em três dimensões: ajudar na mensuração mais objetiva do Produto Interno Bruto; realizar uma análise setorial, que permita mostrar o setor que mais riqueza agrega à sociedade e permitir aos órgãos interessados na sua aplicação em análise de investimentos, concessão de financiamentos, subsídios e benefícios fiscais. É nessa terceira dimensão que se inclui o estudo da criação e distribuição de riqueza pela modelo industrial Zona Franca de Manaus, sustentado em incentivos fiscais especiais.

Ao considerar a responsabilidade social que as entidades econômicas possuem aliadas à prestação de contas por parte dessas organizações às sociedades em que elas operam, por essas últimas terem proporcionado um ambiente legal, sustentado e moral para sua atuação, fica claro que a Demonstração de Valor Adicionado possui elevado alcance social e grande relevância explicativa para a forma de criação e distribuição de riqueza pelas organizações.

Muñoz (1989) acrescenta que a "DVA pode ser utilizada como uma ferramenta básica na análise patrimonial, econômica e financeira, constituindo-se em um importante complemento do lucro contábil, ao manifestar diferentes magnitudes econômicas e sociais que estão relacionadas na atividade empresa." 
No cenário internacional, os trabalhos sobre DVA procuram mostrar a utilidade da Demonstração de Valor Adicionado concentrando-se, principalmente, no estudo relativo ao desempenho de valor adicionado das firmas; na avaliação de mercado e valor adicionado versus dados convencionais e na habilidade preditiva dos dados de valor adicionado. (BELKAOUI, 1999, p. 58-63).

Os trabalhos de Bentley (1981), Meek e Gray (1988), Karpik e Belkaoui (1989), Bannister e Belkaoui (1991), Belkaoui (1993, 1994, 1996, 1997, 1999), Askren et al. (1994), Belkaoui e Fekrat (1994), Belkaoui e Picur (1994), Pavlik e Belkaoui (1994), Bao e Bao (1996), Evraert (1998) e Picur (2007) são exemplos de pesquisas desenvolvidas sobre a Demonstração de Valor Adicionado.

Bentley (1981) afirma que o conceito de valor adicionado é importante na atividade gerencial, pois permite avaliar o desempenho e propicia ferramentas para a tomada de decisão baseada em critérios eficazes de desempenho.

Meek e Gray (1988) realizaram uma pesquisa que procurou resumir as principais questões em torno da Demonstração de Valor Adicionado (DVA) e sugerir que as companhias dos EUA considerem incluir uma DVA em seus informes anuais. Eles concluem seu trabalho fazendo uma proposição para que, como uma divulgação suplementar, a Demonstração de Valor Adicionado possa redirecionar a atenção a determinadas implicações mais amplas da atividade da corporação.

O trabalho de Karpik e Belkaoui (1989) procurou explicar o risco de mercado com a utilização de variáveis do valor adicionado. A conclusão a que chegaram foi que as variáveis de valor adicionado processam a informação incremental além de ganhos acumulados e dos fluxos de caixa no contexto de explicação do risco de mercado.

Por sua vez, Bannister e Belkaoui (1991) buscaram explicar os retornos anormais da firmaalvo durante o período da aquisição majoritária. Concluíram que as firmas-alvo de aquisição majoritária têm valor adicionado mais baixo do que a taxa total de outras empresas em seus setores no ano que precede à conclusão da aquisição majoritária e os retornos anormais das firmas-alvo observados durante o período da aquisição majoritária, estão relacionados com a diferença entre o valor adicionado da empresa-alvo e o valor adicionado do setor em geral. 
Belkaoui (1993), ao pesquisar o conteúdo relativo e incremental do valor adicionado, do ganho e do fluxo de caixa, concluiu que a informação do valor adicionado pode fornecer algum poder explanatório além daquele fornecido pelas medidas de ganhos ou fluxo de caixa. Em 1996, Belkaoui analisou as características funcionais que relacionam ganhos inesperados ou valor adicionado líquido aos retornos ajustados pelo mercado. Como resposta, ele conseguiu descobrir que os modelos que relacionam retornos contábeis e de mercado têm maior poder explanatório quando: (a) os retornos contábeis são expressos pelas mudanças relativas no valor adicionado líquido e (b) a relação é uma função côncava-convexa não linear.

O trabalho de Belkaoui (1997) foi dedicado ao estudo da adoção de plano de desempenho e estrutura de participação acionária, chegando à conclusão de que, depois da adoção do plano de desempenho, a rentabilidade aumentará em empresas controladas por proprietários, mas não nas empresas controladas pelos administradores. Por sua vez, seu trabalho de 1999 teve o objetivo de testar, empiricamente, o modelo de política de valor adicionado líquido: ganhos.

Ele chegou às seguintes conclusões:

\footnotetext{
Que "ganhos" é determinado como um processo de resposta à riqueza gerada pela empresa, medida pelo valor adicionado líquido, e por um processo de ajuste ao nível precedente de "ganhos".

A existência de um coeficiente de resposta de valor adicionado líquido positivo, no sentido de que a administração da empresa determina o nível de ganhos proporcionalmente ao nível de riqueza gerada como aquela medida pelo valor adicionado. (BELKAOUI, 1999, p. 398). ${ }^{50}$
}

Pavlik e Belkaoui (1994, p. 24) observaram os efeitos da Demonstração do Valor Adicionado sobre a estrutura de participação acionária da empresa, encontrando a resposta de que "Há um relacionamento não monotônico significativo entre o desempenho do valor adicionado e a estrutura de participação acionária."

Bao e Bao (1996) examinaram as propriedades das séries temporais de valor adicionado bem como a acurácia de sua previsão. Eles detectaram que o modelo aleatório, que indica que os efeitos dos fatores que afetam o valor adicionado e a direção de mudanças, não são

\footnotetext{
50 "That earnings is determined as a process of response to the wealth generated by the firm, measured by net value added, and a process of adjustment to the previous earnings level.

Existence of a positive net value added response coefficient, in the sense that the management of the firm determines the level of earnings proportionally to the level of wealth generated as measured by the value added."
} 
previsíveis, melhor se ajustavam às medidas de valor adicionado e eram consistentes com aquelas de ganhos anuais e preços das ações. Nesse mesmo período, eles analisaram a associação entre a produtividade e o valor da empresa, chegando à conclusão de que a associação entre o valor da firma e a produtividade nas indústrias de refino de petróleo e as indústrias de vestuário é mais forte do que aquela entre o valor da firma e as medidas de ganhos.

Em 1994, Belkaoui e Picur analisaram se o conteúdo relativo e incremental da informação do valor adicionado causaria mudanças nos preços dos títulos. Ao mesmo tempo, pesquisaram a relação de mudanças e níveis do valor adicionado no preço de mercado dos títulos. Eles concluíram que

O estudo confirma uma associação entre as mudanças relativas nos ganhos e valor adicionado líquido com as mudanças relativas nos preços dos títulos. (Ibid., p.49). ${ }^{51}$

Tanto os níveis quanto as mudanças no valor adicionado líquido desempenham um papel importante na avaliação de títulos. (Ibid., p.59). ${ }^{52}$

Belkaoui e Fekrat (1994) destacam que os números dos indicadores de desempenho baseados no valor adicionado líquido apresentaram uma variabilidade mais baixa e uma persistência mais elevada do que os números correspondentes baseados nos ganhos ou nos fluxos de caixa.

Por sua vez, Askren et al. (1994) afirmam que as empresas que adotam planos de desempenho baseados na contabilidade não experimentam nenhum ganho maior no retorno contábil ou na medida de produtividade do que o grupo de controle de empresas, com planos de desempenho baseados no valor adicionado líquido.

Evraert (1998, p. 6), por meio de uma resenha e síntese da literatura sobre a Demonstração de Valor Adicionado, analisou a utilidade dessa demonstração e concluiu que

O custo do relatório desses dados deveria ser relativamente imaterial dada a disponibilidade de toda informação contida no valor adicionado. Dado o baixo custo relativo comparado aos benefícios potencialmente muito maiores, mostrados neste artigo, parece ser um aperfeiçoamento

\footnotetext{
51 "The study confirms an association between both relative changes in earnings and net value added and the relative changes in security prices."

52 "Both the levels of net value added and the changes in net value added play a role in security valuation"
} 
sobre o sistema atual de relatórios dos EUA, liberar relatórios de valor adicionado, ou evidenciar os dados subjacentes necessários para computar o valor adicionado. ${ }^{53}$

Picur (2007, p. 15) pesquisou os efeitos do conhecimento contábil sobre a omissão da informação de valor adicionado acerca de decisões de medida e distribuição de riqueza e examinou se o conhecimento contábil está associado com a tendência dos responsáveis pelas decisões de ignorar a informação de valor adicionado nas decisões de medidas e distribuição de riqueza. Como resposta, ele obteve que existe

Evidência empírica de que os altos níveis de conhecimento contábil interferem com a habilidade dos tomadores de decisões de incorporar a informação de valor adicionado (contra o lucro da contabilidade) em decisões de medidas e distribuição de riqueza. ${ }^{54}$

No Brasil, os trabalhos de De Luca (1991, 1996), Martins (1993), Santos (1997, 1998, 1999, 2005), Yoshioka (1998), Ribeiro e Lisboa (1999), Kroetz (2000), Cunha (2002) Parmezzano (2002), Cosenza et al. (2002), Chan et al. (2003), Cosenza (2003), Oliveira e Alves (2003), Ribeiro e Cunha (2003), Rodrigues Júnior (2003), Santos e Hashimoto (2003), Silva et al. (2003), Dalmácio (2004), Bettiol et al. (2005), Cunha et al. (2005), Gallo et al. (2006) Rodrigues et al. (2007) abordam a Demonstração de Valor Adicionado sobre os mais diferentes aspectos.

De Luca (1991, p. 3) apresenta um dos primeiros trabalhos realizados sobre a Demonstração de Valor Adicionado no Brasil e afirma que seu objetivo é contribuir para a evolução da Contabilidade Social. Diz tratar-se do início de um estudo sobre a forma de apresentar a criação e distribuição de riqueza gerada pela empresa, num certo período. Dentre as diversas conclusões, destacam-se:

\footnotetext{
A Demonstração do Valor Adicionado considera as atividades da empresa como um esforço coletivo de vários grupos de pessoas e apresenta o valor da riqueza criada, distribuída entre esses grupos. Do valor total da riqueza gerada (valor adicionado) pela empresa, é apresentada, separadamente, a parcela que se destina a remuneração de cada grupo:

- acionistas: pelo capital investido na empresa;

- empregados: pela força de trabalho;
}

\footnotetext{
53 "The cost of reporting of this data should be relatively immaterial given the availability of all the information comprising value added. Given the low cost relative to the potentially much greater benefits shown in this paper, releasing value added reports, or disclosing the underlying data needed to compute value added, appears to be an improvement over the present US reporting system."

54 "Empirical evidence that high levels of accounting knowledge interferes with a decision maker's ability to incorporate value added information (versus accounting profit) in wealth measurement and distribution decisions."
} 
- financiadores: pelos recursos emprestados;

- governo: pela estrutura social, política e econômica que gera condições de operação no meio ambiente; e a

- empresa: pelos recursos investidos. (Ibid., p. 99)

Por valor adicionado, De Luca (1991, p. 99) entende que esse representa o quanto de valor uma empresa agrega aos insumos que adquire num determinado período e é obtido, de forma geral, pela diferença entre as vendas brutas e o total dos insumos adquiridos de terceiros. Ela apresenta a Demonstração de Valor Adicionado como uma nova demonstração para melhorar o nível das informações prestadas aos mais diversos usuários por parte da empresa ao concluir que "É, sem dúvida, uma nova demonstração que vem contribuir para o desenvolvimento da contabilidade no que se refere ao atendimento das necessidades de informações de seus usuários.” (Ibid., p. 101).

Posteriormente, De Luca (1996, p.1) apresenta a Demonstração de Valor adicionado como "um método alternativo para calcular e analisar a produção e a distribuição da riqueza de uma economia partindo de um dos principais grupos de agentes econômicos de um país: as empresas." Essa demonstração apresenta uma visão diferente em termos de demonstrações contábeis e vem evidenciar, além do lucro dos investidores, a quem pertence o restante da riqueza criada pela empresa. (Ibid., p. 66).

Com relação ao ambiente externo, De Luca (1996, p. 91) exemplifica tipos de avaliações que podem ser realizadas a partir das análises que a Demonstração de Valor Adicionado proporciona sobre a participação da empresa no cenário econômico no qual ela atua, tais como:

- contribuição da empresa à sociedade através de pagamentos de impostos ao governo para a realização de obras e manutenção de atividades sociais necessárias ao bem estar da comunidade;

- avaliação do nível de remuneração da força de trabalho da empresa atendendo, principalmente, as necessidades de informações de empregados e de entidades sindicais;

- contribuição da empresa para a produção da riqueza nacional;

- participação da empresa no setor econômico onde atua, com base no cálculo da sua riqueza criada;

- participação da empresa na economia regional e nacional, com base no cálculo da sua riqueza criada. (Ibid., p. 91).

Essas avaliações imprimem uma importância maior à Demonstração de Valor Adicionado do que uma simples demonstração contábil. Para alguns países, o mais importante é o efetivo 
incremento no nível de geração de riqueza e para outros interessa, também, aspectos como geração de empregos, aumento de arrecadação de impostos etc. (DE LUCA, 1996, p. 145).

De Luca (1996, p. 149) afirma que

\begin{abstract}
Além de agilizar mais o processo de obtenção de informações para o órgão responsável pelas contas nacionais, a Demonstração do Valor Adicionado também é importante para outras análises econômicas de diferentes tipos de usuários. Entre essas análises podemos citar o nível de contribuição da empresa para a riqueza da região, a contribuição da empresa à sociedade através de pagamentos de impostos e o nível de participação da mão-de-obra na geração da sua própria riqueza que servirão de base para orientar as decisões de usuários interessados em investir, financiar etc.
\end{abstract}

Por fim, a autora conclui que se todas as atividades econômicas desenvolvidas em uma região específica determinassem sua própria riqueza criada, poderia dizer que a consolidação desses valores, excluídas as duplas contagens, resultaria no PIB dessa região. (Ibid., p. 149).

Ao divulgar que a revista Melhores e Maiores de 1998 apresentaria uma novidade em termos de cálculo para a escolha das melhores e maiores empresas do País, por introduzir informações relativas à Demonstração de Valor Adicionado (DVA), Santos e Carvalho (1997) afirmam que

Outra grande vantagem da DVA está no fato de que, se todas as empresas a elaborarem, a consolidação de seus valores comporia parte substancial da riqueza interna gerada no país, ou seja, o produto interno bruto - PIB. Nesse caso, teríamos o trunfo de não mais trabalhar com valores estimados na fixação do PIB, pois parte determinante de seus componentes passaria a ter maior grau de credibilidade. (Ibid., p. 132-133).

Santos e Lustosa (1998, p. 4) acrescentam que

\begin{abstract}
A distribuição do valor adicionado equivale ao conceito macroeconômico de Renda Nacional. A transformação de recursos intermediários em produtos e serviços finais só é possível pelo emprego dos fatores de produção (trabalho, capital, governo, empresa). Em termos gerais, a remuneração destes fatores (salário, juro, aluguel, imposto e lucro) pelas empresas constitui a renda em poder da sociedade, que retorna às empresas tanto na aquisição de seus produtos e serviços como sob a forma de novos financiamentos, reiniciando o ciclo econômico.
\end{abstract}

Yoshioca (1998, p. 3) diz que, pelo fato de a economia estudar a alocação de recursos escassos para produtos ilimitados, ou seja, a maneira de como obter o máximo de satisfação para os indivíduos a partir de um dado estoque de recursos e para satisfazer às suas necessidades, o homem envolve-se em um ato de produção. Logo, a produção é a atividade social que visa adaptar a natureza para a criação de bens e serviços que permitam a satisfação 
de necessidades humanas. Desse modo, a produção é a principal atividade econômica a ser medida, uma vez que refletirá a capacidade de satisfação das necessidades dos membros da sociedade.

Observa-se a preocupação recorrente em busca de novas métricas que possam contribuir para evidenciações das atividades econômicas e financeiras empresariais que satisfaçam às partes interessadas. Santos (1999, p. 20) complementa

[...] a Demonstração do Valor Adicionado - DVA - é muito mais abrangente, pois não está exclusivamente voltada para a apuração de resultados, porquanto considera outros fatores de produção e aponta suas respectivas remunerações.

Kroetz (2000, p. 42) acrescenta que

Por meio da Demonstração do Valor Agregado é possível perceber a contribuição econômica da entidade para cada segmento com o qual ela se relaciona, constituindo-se no Produto Interno Bruto (PIB), produzido pela organização.

Parmezzano (2002, p. 20), ao elencar as utilidades e benefícios da elaboração de informações sociais, diz que o benefício é mútuo e segue em duas direções, pois a sociedade enxerga a empresa como séria e preocupada com sua atuação social e os empresários sentem-se honrados e orgulhosos por estarem evidenciando esse tipo de informação, tornando a empresa mais transparente e consciente de sua responsabilidade social.

Nessa mesma linha de raciocínio, Cosenza et al. (2002), ao analisarem a participação dos agentes econômicos no valor adicionado na indústria siderúrgica brasileira, concluem que "o valor adicionado é importante por traduzir a intervenção da empresa no processo econômico seqüencial - no âmbito de um determinado sistema econômico - e permitir a obtenção de informações sobre a geração e a distribuição de renda" e que "Também é importante, no âmbito macroeconômico, como gerador de subsídios para medir a produção nacional, calcular e analisar a produção e a riqueza de uma economia, em qualquer magnitude.” Implicitamente, eles defendem a idéia da utilização da demonstração para análise, decisão e acompanhamento de políticas de emprego e renda, política tributária, política de concessão de incentivos fiscais, política industrial e política de investimentos sociais. 
Santos e Hashimoto (2003, p. 154) dizem que com a utilização da Demonstração de Valor Adicionado

[...] desloca-se a visão da contabilidade como instrumento a serviços daqueles que investiram no negócio (os acionistas ou stockholders) para uma nova ótica, em que a contabilidade é utilizada como ferramenta útil aos que têm interesses de natureza diversa no mesmo negócio (stakeholders).

O trabalho de Santos e Hashimoto (2003) apresenta o objetivo de evidenciar alguns aspectos acerca da carga tributária efetivamente suportada pelas empresas. Eles afirmam que

Ao agrupar os encargos de natureza tributária, a DVA torna possível avaliar quantitativamente e qualitativamente a respectiva carga tributária suportada pela empresa, bem como permite uma comparação imediata com outras empresas do mesmo setor, ou entre setores distintos, relativamente a essa carga. Permite, ainda, que esses encargos sejam comparados com o valor adicionado, que é a riqueza gerada pela empresa, em vez de compará-lo com seu faturamento. (Ibid., p. 158).

Santos e Hashimoto (2003, p. 158) esclarecem que, com relação à carga tributária das empresas, a Demonstração de Resultado do Exercício e a Demonstração de Valor Adicionado apresentam conceitos distintos, uma vez que

$\mathrm{Na}$ demonstração de resultado do exercício, além de figurarem em itens específicos, como impostos sobre vendas e provisão para imposto de renda, os encargos com impostos, taxas e contribuições podem estar incluídos em diversos outros itens da demonstração, como, por exemplo, nas despesas de vendas, nas despesas administrativas, nos resultados financeiros e até mesmo, em determinadas situações, nos custos dos produtos vendidos.

Dentre as vantagens do uso da demonstração de valor adicionado, ressaltando que a DVA não evidencia os impostos suportados pelos acionistas e empregados, por exemplo, Santos e Hashimoto (2003, p. 163) concluem que:

Ao produzir informações sobre o valor adicionado pela empresa, e por ser a única demonstração contábil que agrupa todos os encargos tributários suportados por ela, um dos principais usos proporcionados pela DVA é a avaliação da sua carga tributária.

$[\ldots]$

Diferentemente da demonstração de resultados, a DVA apresenta de forma mais apropriada os denominados impostos sobre o valor adicionado, como o ICMS e o IPI, pois evidencia apenas o imposto incidente sobre a riqueza gerada dentro da empresa, e não inclui os impostos incidentes em etapas anteriores.

Cosenza (2003, p. 17), ao analisar a eficácia informativa da Demonstração de Valor Adicionado, conclui que "a informação contábil deve estar cada vez mais orientada para satisfazer múltiplos e diferentes objetivos da informação e fornecer dados necessários e 
corretos para cada situação concreta. Isso fará com que se caminhe na direção de um sistema contábil estruturado numa visão multidimensional."

Ribeiro e Cunha (2003, p. 3) dizem que “o sistema de informações contábeis disponível, representado pelas demonstrações tradicionais e voltado essencialmente para o desempenho econômico-financeiro, não possibilita a obtenção desses novos dados que interessam a tantos" e que são fornecidos pela Demonstração de Valor Adicionado. Acrescentam, ainda, que

o sistema de informações contábeis tradicional e disponível não mostra nem mensura o impacto do desempenho social da empresa e seu relacionamento com a comunidade onde está inserida, relegando a um plano secundário alguns usuários que contribuem, direta ou indiretamente, para a geração de riqueza das organizações. (Ibid., p. 3).

O trabalho de Chan et al. (2003), ao pesquisar o efeito da propriedade do capital e investigar a sua influência na contribuição da empresa à sociedade em termos da estrutura de distribuição do valor adicionado entre os agentes econômicos empregados, governo, credores e acionistas, à luz do modelo da Demonstração de Valor Adicionado (DVA), utiliza o termo riqueza como proxy do conceito de Produto Interno Bruto (PIB), com diferenças principalmente temporais.

A pesquisa foi realizada com o objetivo de estudar se existiam diferenças de distribuição de riqueza para os diversos agentes econômicos entre as empresas estatais e privadas, contemplando o período de 1998 a 2002, e chegou às seguintes conclusões

não foi observada a existência de indícios que levem a acreditar que as empresas privadas remuneram mais os acionistas e o governo que as estatais. Somente em relação ao percentual médio da participação da mão de obra na composição da distribuição do valor adicionado, foi verificada que as estatais destinaram maior parcela da riqueza gerada que as entidades privadas. (CHAN et al., 2003, p. 14).

Silva et al.(2003) realizaram uma pesquisa com o objetivo de identificar os possíveis impactos da privatização no desempenho econômico das empresas. Foi selecionada uma amostra de 08 (oito) empresas, no período de 1996 a 2002, e obtiveram a resposta de que nas empresas analisadas ocorreu um melhor desempenho econômico da empresa privada em relação à estatal e que, para essas empresas, isso pôde ser comprovado por meio do indicador de geração de riqueza que demonstrou que, praticamente, todas as empresas analisadas melhoraram seus desempenhos em relação ao período anterior à privatização. 
Embora tenham sido utilizados como período de pesquisa apenas dois anos, 2001 e 2002, o trabalho de Oliveira e Alves (2003) investigou a evolução e o atual estágio da evidenciação da DVA no Brasil. A conclusão obtida foi a de que não houve grandes alterações no percentual de empresas que evidenciam a DVA nesse período.

Rodrigues Jr. (2003) utilizou a técnica de estudo de casos para discutir a utilização da Demonstração de Valor Adicionado como instrumento para a mensuração da relação custobenefício na concessão de incentivos fiscais. Ele destaca a utilização da DVA "como um dos possíveis instrumentos a serem utilizados pelo governo na análise do mérito do projeto de empresas que desejem se instalar em regiões menos favorecidas", uma vez que o fato de a legislação não estabelecer parâmetros a serem utilizados, a análise fica sujeita à subjetividade e influências políticas. (Ibid., p. 139).

Dalmácio (2004, p. 90) sugeriu a utilização de indicadores que possam auxiliar na evidenciação das informações contidas na DVA, sua interpretação e análise. A autora analisa alguns indicadores extraídos dessa demonstração contábil que podem complementar uma análise sobre o desempenho da empresa além do desempenho econômico-financeiro tradicional.

O estudo da validade da Demonstração de Valor Adicionado como instrumento de identificação dos efeitos socioeconômicos da política de atração de investimentos mediante renúncia fiscal foi desenvolvido por Alencar (2005, p. 1-2) com os objetivos de: identificar a contabilidade como instrumento de mensuração dos efeitos socioeconômicos decorrentes de incentivos fiscais; identificar a validade de tornar obrigatória a publicação da Demonstração de Valor Adicionado e comparar as conclusões de um estudo de natureza econômica com as informações geradas pela contabilidade.

Como resultado dessa pesquisa, Alencar (2005, p. 20) afirma que

[...] a contabilidade, de fato é um importante instrumento de mensuração e avaliação dos efeitos socioeconômicos decorrente dos incentivos fiscais. Que através da Demonstração de Valor Adicionado, pode evidenciar o quanto de riqueza foi gerado pelas empresas incentivadas e como se deu sua distribuição entre os fatores de produção dessa riqueza: empregados, investidores e governos. 
O trabalho de Cunha et al. (2005) busca avaliar o poder de aferição da DVA, no que diz respeito às informações sobre a formação de riqueza pelas empresas e sua distribuição aos agentes econômicos que ajudaram a criá-la, como: empregados, governos, financiadores externos e proprietários. Eles acrescentam que "Uma empresa, normalmente, tem capacidade de geração de riqueza bem maior do que o lucro que distribui aos seus sócios ou acionistas." (Ibid., p. 9).

Dentre as conclusões sobre a importância e utilidade da Demonstração de Valor Adicionado, Cunha et al. (2005, p. 21) apresentam:

\begin{abstract}
Além de atender a um maior número de usuários, quando comparada à DRE, amplia o universo atingido pela contabilidade e tem a grande vantagem de ser facilmente lida e interpretada.

[...] consegue-se perceber como a riqueza criada foi distribuída aos agentes e quais deles ficaram com a maior parte dela, possibilitando, inclusive, avaliações sobre se esses são os agentes que mais colaboraram na sua criação.
\end{abstract}

A Demonstração de Valor Adicionado foi utilizada em um estudo de caso sobre a formação e evidenciação de entidades do terceiro setor. Bettiol Jr. et al. (2005, p. 14) chegaram à conclusão de que com base na análise dessa demonstração "é possível concluir que essa demonstração mostra-se mais adequada ao atendimento das necessidades dos usuários das informações contábeis do terceiro setor, quando comparado à demonstração do resultado do exercício.” Eles complementam afirmando que

\begin{abstract}
A avaliação dos resultados das atividades fim das entidades que compõem o terceiro setor deveria ser realizada com foco na sociedade, apurando-se tanto os custos e benefícios diretos quanto os custos e benefícios secundários (externalidades), sendo que o custo de oportunidade do superávit apurado nas atividades comerciais e/ou de prestação de serviços corresponderia à totalidade ou parte das despesas das atividades-fim. (Ibid., p. 15).
\end{abstract}

Rodrigues et al. (2007) analisaram a forma de utilização do valor adicionado entre o valor bruto ou valor líquido em função do tratamento à depreciação e chegaram a resultados não conclusivos. Eles alegaram que esses resultados parecem ter sido afetados pelo tamanho da amostra e, possivelmente, pelo viés existente na mensuração da depreciação contábil.

Gallo et al. (2006) utilizaram a DVA para análise da carga tributária do Brasil e confrontaram se a carga tributária efetivamente medida por meio dessa demonstração se traduzia na carga tributária divulgada pelas autoridades brasileiras. Eles chegaram à conclusão de que 
no período de 2000 a 2004, as empresas selecionadas recolheram ao governo brasileiro uma carga tributária média efetiva superior à carga tributária média divulgada oficialmente pela SRF. A despeito das divergências e restrições metodológicas, essa constatação sugere uma possível subestimação da carga tributária divulgada pelos órgãos oficiais do governo para o grupo de empresas estudado, a qual, contudo, não pode ser generalizada. Essa diferença tanto pode ter sido causada por divergências metodológicas entre as abordagens econômica e contábil, quanto por uma limitação da amostra ou por características peculiares do grupo de empresas estudado. (GALLO et al., 2006, p. 13).

Sobre a função e utilidade das demonstrações contábeis existentes, pode-se citar a afirmativa de Iudícibus (2004) de que a restrição informacional nos modelos de demonstrações contábeis existe porque não se conhecem, suficientemente, os detalhes do modelo decisório de cada usuário e, enquanto isso não for conseguido, a contabilidade não poderá atender igualmente a todos os seus usuários. Nesse aspecto, a DVA surge como mais uma demonstração contábil buscando preencher parte dessa lacuna de informações.

Hendriksen e Breda (1999, P. 94) complementam citando o posicionamento do FASB e do AICPA:

O FASB e o AICPA reconhecem a importância dos argumentos em favor de relatórios de finalidades específicas, mas argumentam, em contrapartida, que os usuários possuem o bastante em comum para que um conjunto de demonstrações de finalidades genéricas seja suficiente.

O modelo utilizado pelas empresas brasileiras, de forma voluntária, até o exercício de 2007, é o desenvolvido pela Fundação Instituto de Pesquisas Contábeis Atuariais e Financeiras (FIPECAFI), apresentado por meio do Quadro 06, a seguir, cuja utilização foi recomendada pela Comissão de Valores Mobiliários (CVM) às companhias abertas. 
Quadro 6 - Estrutura da Demonstração de Valor Adicionado (DVA)

DEMONSTRAÇÃO DO VALOR ADICIONADO DO EXERCÍCIO DE 200X

\begin{tabular}{|l|l|}
\hline \multicolumn{1}{|c|}{ DESCRIÇÃO } & $\begin{array}{c}\text { em milhares de reais } \\
\text { pela Legislação } \\
\text { Societária }\end{array}$ \\
\hline 1 - RECEITAS & \\
1.1) Vendas de Mercadorias, produtos e serviços & \\
1.2) Provisão p/ devedores duvidosos - Reversão (Constituição) \\
1.3) Não Operacionais & \\
2 - INSUMOS ADQUIRIDOS DE TERCEIROS & \\
(inclui os valores dos impostos - ICMS E IPI) & \\
2.1) Matérias-primas consumidas & \\
2.2) Custo das Mercadorias e Serviços Vendidos \\
2.3) Materiais, energia, serviços de terceiros e outros \\
2.4) Perda/Recuperação de valores ativos & \\
3 - VALOR ADICIONADO BRUTO ( 1 - 2 ) & \\
4 - RETENÇÕES & \\
4.1) Depreciação, amortização e exautão & \\
5 - VALOR ADICIONADO LÍQUIDO PRODUZIDO PELA ENTIDADE ( 3 -4) & \\
6 - VALOR ADICIONADO RECEBIDO EM TRANSFERÊNCIA & \\
6.1 - Resultado de Equivalência Patrimonial & \\
6.2 - Receitas Financeiras & \\
7 - VALOR ADICIONADO TOTAL A DISTRIBUIR ( 5 + 6) & \\
8) DISTRIBUIÇÃO DO VALOR ADICIONADO & \\
8.1) Pessoal e encargos & \\
8.2) Impostos, taxas e contribuições & \\
8.3) Juros e aluguéis & \\
8.4) Juros s/capital próprio e dividendos & \\
8.5) Lucros retidos/prejuízo do exercício & \\
$\quad$ * O total do item 8 deve ser exatamente igual ao item 7. & \\
\hline FIPECAFI - FUNDAÇÃO INSTITUTO DE PESQUISAS, ATUARIAIS E FINANCEIRAS - (FEA - USP) \\
\hline \multicolumn{1}{|c|}{ A DVA deverá ser referente ao exercício social da empresa } \\
\hline
\end{tabular}

Santos (2003) apresenta modelos de DVA para empresas em geral, empresas de prestação de serviços, instituições financeiras, dentre outros. O modelo apresentado no Quadro 6 acima destina-se a empresas em geral. Nas instruções para o preenchimento, Santos (2003, p. 40-42) explica o que compõe cada item da DVA, a saber: 
- 1.1. Vendas de mercadorias, produtos e serviços: corresponde à receita bruta ou faturamento bruto, com os tributos (ICMS, IPI, PIS/COFINS) incidentes sobre essas receitas inclusos;

- 1.2. Provisão para devedores duvidosos - Reversão/Constituição: inclui os valores relativos à constituição/baixa de provisão para devedores duvidosos;

- 1.3. Não operacionais: inclui valores considerados fora das atividades principais da empresa, tais como: ganhos ou perdas na baixa de imobilizados, ganhos ou perdas na baixa de investimentos etc.;

- 2.1. Matérias-primas consumidas: correspondem às matérias-primas consumidas e incluídas no custo do produto vendido, com os tributos (ICMS, IPI, PIS/COFINS), recuperáveis ou não, incidentes na época das compras;

- 2.2. Custo das mercadorias e serviços vendidos: correspondem aos demais custos das mercadorias e serviços vendidos, não incluídos gastos com pessoal próprio, com os tributos (ICMS, IPI, PIS/COFINS), recuperáveis ou não, incidentes na época das compras;

- 2.3. Materiais, energia, serviços de terceiros e outros: inclui os valores relativos às aquisições e pagamentos a terceiros, com os tributos (ICMS, IPI, PIS/COFINS), recuperáveis ou não, incidentes na época das compras;

- 2.4. Perda/Recuperação de valores ativos: inclui valores relativos a valor de mercado de estoques e investimentos etc.;

- 4.1. Depreciação, amortização e exaustão: corresponde a despesas de depreciação, amortização e exaustão, contabilizada no período;

- 6.1. Resultado de equivalência patrimonial: inclui os valores recebidos como dividendos relativos a investimentos avaliados ao custo;

- 6.2. Receitas Financeiras: inclui todas as receitas financeiras, independentemente de sua origem;

- $\quad$ 8.1. Pessoal e encargos: corresponde às despesas com pessoal e encargos, incluídos os valores relativos aos encargos com férias, 13- Salário, FGTS, alimentação, transporte etc., apropriados ao custo do produto ou resultado do período;

- $\quad$ 8.2. Impostos, taxas e contribuições: correspondem, além das contribuições devidas ao INSS, Imposto de Renda, contribuição social, todos os demais tributos. Os valores relativos ao ICMS, IPI, PIS, COFINS devem ser considerados como valores devidos ou já recolhidos aos cofres públicos, representando a diferença entre os tributos incidentes 
sobre as vendas e os valores considerados dentro do item Insumos adquiridos de terceiros;

- 8.3. Juros e aluguéis: correspondem às despesas financeiras e de juros relativas a quaisquer tipos de empréstimos e financiamentos em instituições financeiras, empresas do grupo ou outras e os aluguéis (incluindo-se as despesas com leasing) pagos ou creditados a terceiros;

- $\quad$ 8.4. Juros sobre capital próprio e dividendos: correspondem aos valores pagos ou creditados aos acionistas. Os juros sobre o capital próprio contabilizados como reserva devem constar no item Lucros retidos (8.5) e

- 8.5. Lucros retidos/prejuízo do exercício: correspondem aos lucros do período destinados às reservas e eventuais parcelas ainda sem destinação específica.

A apresentação do modelo do Quadro 06 e a explicação de cada item fazem-se necessárias pelo fato de que este trabalho utilizou aquela estrutura e esses conceitos, uma vez que era o modelo adotado pelas empresas em geral até o ano de 2007, o qual serviu de base para todas as Demonstrações de Valor Adicionado utilizadas nesta pesquisa.

Com o advento da Lei n. 11.638, de 28 de dezembro de 2008, tornou-se obrigatória a divulgação da Demonstração de Valor Adicionado (DVA) para as companhias abertas, estabelecendo que a Demonstração de Valor Adicionado deve evidenciar o valor da riqueza gerada pela companhia, a sua distribuição entre os elementos que contribuíram para a geração dessa riqueza, tais como: empregados, financiadores, acionistas, governo e outros, bem como a parcela da riqueza não distribuída.

O Comitê de Pronunciamentos Contábeis (CPC) foi criado pela Resolução CFC n. 1055/05, com a união de esforços das entidades: ABRASCA, representando as companhias abertas; APIMEC NACIONAL, os analistas e profissionais de mercado de capitais; BOVESPA, as corretoras e os operadores de mercado; CFC, os profissionais de contabilidade; FIPECAFI, a Academia e IBRACON, representando os auditores independentes.

O objetivo do CPC, segundo a Resolução CFC n. 1.055/05, é

o estudo, o preparo e a emissão de Pronunciamentos Técnicos sobre procedimentos de Contabilidade e a divulgação de informações dessa natureza, para permitir a emissão de normas pela entidade reguladora brasileira, visando à centralização e uniformização do seu processo de 
produção, levando sempre em conta a convergência da Contabilidade Brasileira aos padrões internacionais.

As características básicas do CPC podem ser, assim, sintetizadas:

- $\quad$ comitê totalmente autônomo das entidades representadas, com deliberações de $2 / 3$ dos seus membros;

- $\quad$ sua estrutura necessária é fornecida pelo Conselho Federal de Contabilidade;

- $\quad$ cada entidade representada possui dois membros;

- a maioria dos membros são contadores;

- $\quad$ os membros não auferem remuneração;

- $\quad$ embora sejam seis as entidades representadas, outras entidades ou especialistas podem ser convidados e

- além dos 12 membros atuais, serão sempre convidados a participar membros dos seguintes órgãos: Banco Central do Brasil, Comissão de Valores Mobiliários; Receita Federal do Brasil e Superintendência de Seguros Privados.

Um dos pronunciamentos técnicos emitido pelo Comitê de Pronunciamentos Contábeis foi o CPC 09, que aprovou a Demonstração do Valor Adicionado, em 30 de outubro de 2008, cujo modelo é o constante do Quadro 07, a seguir, e já aprovado pelas normas dos seguintes órgãos:

- $\quad$ Resolução CFC n. 1.138/08, de 21 de novembro de 2008;

- $\quad$ Deliberação CVM, n. 557, de 12 de novembro de 2008;

- $\quad$ Circular SUSEP n. 379, de 19 de dezembro de 2008 e

- $\quad$ Despacho ANEEL n. 4.796, de 24 de dezembro de 2008. 
Quadro 7 - Estrutura da Demonstração de Valor Adicionado (DVA) aprovada pelo CPC

\begin{tabular}{|c|c|c|}
\hline DESCRIÇÃO & $\begin{array}{c}\text { Em milhares } \\
\text { de reais } \\
\text { 20X1 }\end{array}$ & $\begin{array}{c}\text { Em milhares } \\
\text { de reais } \\
\text { 20X0 }\end{array}$ \\
\hline \multicolumn{3}{|l|}{1 - RECEITAS } \\
\hline \multicolumn{3}{|l|}{ 1.1) Vendas de mercadorias, produtos e serviços } \\
\hline \multicolumn{3}{|l|}{ 1.2) Outras receitas } \\
\hline \multicolumn{3}{|l|}{ 1.3) Receitas relativas à construção de ativos próprios } \\
\hline \multicolumn{3}{|l|}{$\begin{array}{l}\text { 1.4) Provisão para créditos de liquidação duvidosa }- \text { Reversão / } \\
\text { (Constituição) }\end{array}$} \\
\hline \multicolumn{3}{|l|}{$\begin{array}{l}2 \text { - INSUMOS ADQUIRIDOS DE TERCEIROS } \\
\text { (inclui os valores dos impostos - ICMS, IPI, PIS e COFINS) }\end{array}$} \\
\hline \multicolumn{3}{|l|}{ 2.1) Custos dos produtos, das mercadorias e dos serviços vendidos } \\
\hline \multicolumn{3}{|l|}{ 2.2) Materiais, energia, serviços de terceiros e outros } \\
\hline \multicolumn{3}{|l|}{ 2.3) Perda / Recuperação de valores ativos } \\
\hline \multicolumn{3}{|l|}{ 2.4) Outras (especificar) } \\
\hline \multicolumn{3}{|l|}{3 - VALOR ADICIONADO BRUTO (1-2) } \\
\hline \multicolumn{3}{|l|}{4 - DEPRECIAÇÃO, AMORTIZAÇÃO E EXAUSTÃO } \\
\hline \multicolumn{3}{|l|}{$\begin{array}{l}5 \text { - VALOR ADICIONADO LÍQUIDO PRODUZIDOS PELA } \\
\text { ENTIDADE (3-4) }\end{array}$} \\
\hline \multicolumn{3}{|l|}{6 - VALOR ADICIONADO RECEBIDO EM TRANSFERÊNCIA } \\
\hline \multicolumn{3}{|l|}{ 6.1) Resultado de equivalência patrimonial } \\
\hline \multicolumn{3}{|l|}{ 6.2) Receitas financeiras } \\
\hline \multicolumn{3}{|l|}{ 6.3) Outras } \\
\hline \multicolumn{3}{|l|}{7 - VALOR ADICIONADO TOTAL A DISTRIBUIR (5+6) } \\
\hline \multicolumn{3}{|l|}{8 - DISTRIBUIÇÃO DO VALOR ADICIONADO (*) } \\
\hline \multicolumn{3}{|l|}{ 8.1) Pessoal } \\
\hline \multicolumn{3}{|l|}{ 8.1.1 - Remuneração direta } \\
\hline \multicolumn{3}{|l|}{ 8.1.2-Benefícios } \\
\hline \multicolumn{3}{|l|}{$8.1 .3-$ F.G.T.S } \\
\hline \multicolumn{3}{|l|}{ 8.2) Impostos, taxas e contribuições } \\
\hline \multicolumn{3}{|l|}{$8.2 .1-$ Federais } \\
\hline \multicolumn{3}{|l|}{ 8.2.2- Estaduais } \\
\hline \multicolumn{3}{|l|}{8.2 .3 - Municipais } \\
\hline \multicolumn{3}{|l|}{ 8.3) Remuneração de capitais de terceiros } \\
\hline \multicolumn{3}{|l|}{$8.3 .1-$ Juros } \\
\hline $8.3 .2-$ Aluguéis & & \\
\hline 8.3 .3 - Outras & & \\
\hline 8.4) Remuneração de Capitais Próprios & & \\
\hline 8.4.1 - Juros sobre o Capital Próprio & & \\
\hline 8.4 .2 - Dividendos & & \\
\hline 8.4.3 - Lucros retidos / Prejuízo do exercício & & \\
\hline $\begin{array}{l}8.4 .4 \text { - Participação dos não-controladores nos lucros retidos (só p/ } \\
\text { consolidação) }\end{array}$ & & \\
\hline
\end{tabular}

(*) O total do item 8 deve ser exatamente igual ao item 7.

Embora as premissas do modelo adotado pelo CPC sejam as mesmas do modelo anteriormente desenvolvido pela FIPECAFI e, até então, adotado pelas empresas, observa-se que o modelo definido pelo CPC e que vem sendo aprovado e adotado por outros órgãos, apresenta um maior detalhamento das parcelas distribuídas da riqueza, gerando uma melhor qualidade das informações.

Ressalte-se o fato de que esse modelo está sendo utilizado a partir do período de 2008 e, por isso, não contemplado neste estudo. 



\section{O MODELO INDUSTRIAL ZONA FRANCA DE MANAUS}

A Zona Franca de Manaus merece um capítulo especial. Além da escassa literatura existente sobre o tema, existe um desconhecimento do elevado número de conceitos e procedimentos operacionais envolvidos. Esse capítulo busca traçar o histórico da Zona Franca de Manaus, desde a sua criação até os dias atuais, apresentar os principais conceitos legais, operacionais e financeiros que sustentam esse modelo industrial e comparar um conjunto de dados que dão suporte à validade desse modelo industrial.

O modelo industrial Zona Franca de Manaus foi, originalmente, pensado com a finalidade de criar no interior da Amazônia, um centro industrial, comercial e agropecuário dotado de todas as condições econômicas que permitam o seu desenvolvimento. Caracteriza-se como uma estratégia de política de desenvolvimento econômico, relacionada diretamente às políticas industriais voltadas para a substituição de importações.

A Zona Franca de Manaus apresenta-se com um conceito mais amplo do que uma Zona de Livre Comércio. Além das características de zona franca, trata-se de um regime aduaneiro aplicado em áreas especiais e, ao mesmo tempo, uma área de livre comércio de importação e exportação e de incentivos fiscais especiais. São esses incentivos fiscais que permitem a manutenção do parque industrial instalado.

Em regra geral, para ser instalado um empreendimento industrial com os benefícios fiscais estipulados pela legislação federal, originada na Constituição Federal, os requisitos básicos a serem cumpridos são a apresentação de um projeto de viabilidade econômica e, a partir da sua aprovação, a obtenção de uma resolução que defina o tipo de produto e os benefícios concedidos, bem como a definição de um processo produtivo básico a ser cumprido.

Praticamente, qualquer atividade que seja definida como industrialização pode ser objeto de aprovação para a obtenção dos incentivos fiscais, com exceção de acondicionamento e reacondicionamento. Excluídas da obtenção dos incentivos fiscais estão as famílias dos seguintes produtos: armas e munições, produtos de tabacaria, bebidas alcoólicas, produtos de toucador e automóveis de passeio. 


\title{
3.1 Breve histórico
}

A história da Zona Franca de Manaus teve início, no dia 23 de outubro de 1951, com a apresentação do Projeto de Lei n. 1.310, que propôs a criação de um porto franco na cidade de Manaus. Posteriormente, após diversas emendas, foi convertido na Lei n. 3.173, de 6 de junho de 1957, transformando o porto franco em Zona Franca de Manaus, de acordo com Seráfico e Seráfico (2005, p. 101).

Entretanto, diversos questionamentos e escassez de legislações que regulamentassem o seu funcionamento, mesmo com a sua regulamentação pelo Decreto n. 47.754 , de 2 de fevereiro de 1960, a Zona Franca de Manaus continuava a existir apenas no papel. Somente a partir de 28 de fevereiro de 1967, quando foi reestruturada pelo Decreto-lei n. 288, é que entrou em vigor efetivamente.

Segundo Seráfico e Seráfico (2005, p. 101),

\begin{abstract}
"essa trajetória de quase dezesseis anos entre a apresentação do Projeto de Lei n. 1.310/1951 e a assinatura do Decreto-lei n. 288/1967 foi acompanhada pela sistemática frustração das expectativas de setores da sociedade local quanto a medidas federais que permitissem a redinamização econômica do estado.”
\end{abstract}

Assim, para um melhor entendimento das etapas de evolução da Zona Franca de Manaus, sua história pode ser dividida em quatro fases distintas, conforme o Quadro 8.

\begin{tabular}{|c|l|l|l|l|}
\multicolumn{2}{|c}{ Quadro 8 - Fases históricas da Zona Franca de Manaus } \\
\hline Períodos & \multicolumn{1}{|c|}{$\mathbf{1 9 5 1 - 1 9 6 7}$} & \multicolumn{1}{|c|}{$\mathbf{1 9 6 7 - 1 9 7 5}$} & $\mathbf{1 9 7 5 - 1 9 9 1}$ & \multicolumn{1}{|c|}{$\mathbf{1 9 9 1 - 2 0 0 8}$} \\
\hline Denominação & Embrionária & Afirmação & Consolidação & Desenvolvimentista \\
\hline Característica & $\begin{array}{l}\text { Existência apenas } \\
\text { no papel }\end{array}$ & Início das operações & $\begin{array}{l}\text { Elevado nível } \\
\text { de comércio }\end{array}$ & $\begin{array}{l}\text { Parque industrial } \\
\text { verticalizado }\end{array}$ \\
\hline $\begin{array}{c}\text { Marcos } \\
\text { Regulatórios }\end{array}$ & $\begin{array}{l}\text { Projeto de Lei n. } \\
1.310 / 1951 \\
\text { Lei n. } 3.173 / 1957\end{array}$ & $\begin{array}{l}\text { Decreto-lei n. } \\
288 / 1967 \\
\text { Decreto n. } \\
61.244 / 1967\end{array}$ & $\begin{array}{l}\text { Decreto n. } \\
1.435 / 1975\end{array}$ & Lei n. 8.387/1991 \\
\hline
\end{tabular}

A primeira etapa situa-se no período que vai desde a apresentação do Projeto de Lei, em 23 de outubro de 1951, passando pela sua criação original por meio da Lei n. 3.173/57, até a assinatura do Decreto-lei n. 288, em 28 de fevereiro de 1967. Esse período pode ser considerado como fase embrionária por apresentar os conceitos iniciais de seu funcionamento, 
embora tenha se limitado ao aspecto documental e discursivo por parte das lideranças empresariais e governamentais locais e nacionais.

A etapa seguinte parte de 1967, com a publicação do Decreto-lei n. 288 e do Decreto n. 61.244, que cria a Superintendência da Zona Franca de Manaus - SUFRAMA, até 1975, com a publicação do Decreto n.1.435, em 16 de dezembro, que, ao alterar a redação do art. 70 do Decreto-lei n. 288, de 28 de fevereiro de 1967, incluiu o coeficiente de redução do imposto de importação na alíquota ad valorem das matérias-primas, produtos intermediários e materiais de embalagem importados e empregados nos produtos industrializados naquela região, para pagamento quando os produtos dela saírem para quaisquer outros pontos do território nacional.

Esse período pode ser classificado como de afirmação do modelo por iniciar as suas atividades operacionais, especialmente voltadas para o comércio, mostrando uma característica primordial da Zona Franca de Manaus como uma Zona Franca propriamente dita ou, como muitos autores a classificam, de "porto franco".

Como o modelo industrial criado surgia de uma estratégia de política de desenvolvimento econômico, relacionada diretamente às políticas industriais voltadas para a substituição de importações, cuja função principal era o abastecimento do mercado interno, nessa fase houve a introdução das primeiras indústrias de transformações.

A terceira fase, aqui classificada como de consolidação do modelo, é caracterizada pelo aumento crescente das atividades comerciais e consolidação do parque industrial. Inicia-se em 1975, com a publicação do Decreto n. 1.435, em 16 de dezembro, que, ao introduzir o coeficiente de redução do imposto de importação na alíquota ad valorem das matérias-primas, produtos intermediários e materiais de embalagem importados e empregados nos produtos industrializados naquela região, para pagamento quando os produtos dela saírem para quaisquer outros pontos do território nacional, trouxe uma melhor definição legal para o pagamento do imposto de importação e, com isso, as empresas industriais puderam programar e definir suas planilhas de custos e seus orçamentos.

Nessa fase, além da consolidação das indústrias de transformações, ocorreu o adensamento do parque industrial instalado naquela região. Ao mesmo tempo, em decorrência das tarifas de 
importação serem praticamente proibitivas para o resto do País, enquanto a Zona Franca de Manaus tinha acesso a produtos importados de alta tecnologia devido à suspensão e isenção dos tributos, foi, nessa fase, que o comércio apresentou o maior destaque. Era muito comum as viagens de turismo de compra do resto do Brasil para a Zona Franca de Manaus.

A forma de cálculo do coeficiente de redução de que trata o Decreto n. $1.435 / 75$, foi definida da seguinte maneira, de acordo com os $\S 1^{\circ}$ e e $2^{\circ}$ do art. $1^{\circ}$ que alterou o art. 70 do Decreto-lei n. $288 / 67$, a saber:

$\S 1$ 1o $\mathrm{O}$ coeficiente de redução do imposto será obtido, em relação a cada produto, mediante a aplicação de fórmula que tenha:

a) como dividendo, a soma dos valores das matérias-primas produtos intermediários e materiais de embalagem de produção nacional, e da mão-de-obra direta empregada no processo e de produção; b) como divisor, a soma dos valores das matérias-primas, produtos intermediários e materiais de embalagem, de produção nacional e de origem estrangeira, e da mão-de-obra direta empregada no processo de produção.

§ 2o A redução do Imposto de Importação, a que se refere este artigo, aplica-se somente aos produtos industrializados que atenderem aos índices mínimos de nacionalização estabelecidos conjuntamente pelo Conselho de Administração da SUFRAMA e pelo Conselho de Desenvolvimento Industrial - CDI.

O ponto de corte dessa fase ocorreu em 1991, com a publicação da Lei n. 8.387, de 30 de dezembro de 1991. Foi, a partir de então, que se introduziu o coeficiente de redução fixo (88\%) do imposto de importação a ser pago na venda de um produto industrial para o restante do País.

No período compreendido entre 1991 e 1996, ocorreram significativas mudanças na economia brasileira, principalmente pelo fato de que o Brasil, como membro fundador, passou a integrar a OMC, em 1995. Foi, também, nesse período, que começaram a ser implantadas mudanças que refletissem a abertura da economia ao mercado externo e na qual ocorreram significativas reduções de alíquotas de imposto de importação para o resto do País.

A fase atual caracteriza-se como desenvolvimentista, pois é a partir desse período, 1991, que o parque industrial instalado na Zona Franca de Manaus vem se fortalecendo não só pelo processo de verticalização como também pelo elevado nível de consolidação de alguns segmentos, especialização e produtividade entre outros, mas, igualmente, pela atratividade de novas indústrias de tecnologia avançada, como é o caso do segmento industrial de aparelhos celulares. A Tabela 8, a seguir, mostra as quantidades produzidas e vendidas, no ano de 2007, de alguns produtos líderes de vendas tanto para o mercado doméstico como para o mercado 
externo, ressaltando que, praticamente, a totalidade da produção brasileira desses produtos é realizada no parque industrial da Zona Franca de Manaus.

Tabela 8 - Principais produtos produzidos e vendidos pela Zona Franca de Manaus em 2007

\begin{tabular}{l|r|r}
\hline \multirow{2}{*}{\multicolumn{1}{c|}{ Produtos }} & \multicolumn{1}{|c}{ Quantidade (unidades) } \\
\cline { 2 - 3 } & Produzida & \multicolumn{1}{|c}{ Vendida } \\
\hline Televisor em cores & 10.300 .439 & 10.443 .991 \\
Televisor com tela de plasma & 191.374 & 196.696 \\
Televisor com tela de LCD & 802.798 & 800.640 \\
Cinescópio para televisor & 7.430 .993 & 7.523 .898 \\
Auto-rádio e aparelhos reprodução som & 3.193 .277 & 3.187 .755 \\
Telefone celular & 17.675 .670 & 17.458 .780 \\
Forno de microondas & 2.719 .721 & 2.497 .667 \\
Condicionadores de ar & 924.260 & 870.435 \\
Motocicletas & 1.879 .832 & 1.891 .284 \\
Monitores com tela LCD & 3.825 .494 & 3.759 .819 \\
\hline
\end{tabular}

Fonte: Suframa

Naquela época, também, em decorrência de um maior processo de globalização, dos saldos negativos da Balança Comercial brasileira e da implantação de novas indústrias e novos processos industriais, a Zona Franca de Manaus que exportava o volume de US\$ 125 milhões, em 1995, começou a receber pressão por aumento em exportações para contribuir com o saldo da balança comercial. (BISPO, 2003).

A Tabela 9, a seguir, mostra a participação dos principais setores industriais no faturamento da Zona Franca de Manaus no período de 2003 a 2007. Verifica-se o elevado grau de concentração industrial pela comprovação de que apenas 03 (três) setores são responsáveis por aproximadamente $70 \%$ do faturamento, no ano de 2007 , embora sua concentração tenha ficado abaixo dos $72 \%$ observados nos anos anteriores. Outro ponto a destacar é o crescimento do setor de duas rodas que alcançou 23,27\%, em 2007. 
Tabela 9 - Participação dos principais setores no faturamento da Zona Franca de Manaus - 2003 - 2007

\begin{tabular}{l|c|c|c|c|c}
\hline \multirow{2}{*}{ Setores } & \multicolumn{5}{c}{ Anos } \\
\cline { 2 - 6 } & $\mathbf{2 0 0 3}$ & $\mathbf{2 0 0 4}$ & $\mathbf{2 0 0 5}$ & $\mathbf{2 0 0 6}$ & $\mathbf{2 0 0 7}$ \\
\hline Eletroeletrônico & 31,05 & 34,60 & 35,90 & 34,46 & 29,28 \\
Duas Rodas & 17,66 & 16,84 & 16,72 & 18,34 & 23,27 \\
Bens de Informática & 23,92 & 22,28 & 20,58 & 19,04 & 16,98 \\
\hline Subtotal 1 & $\mathbf{7 2 , 6 3}$ & $\mathbf{7 3 , 7 2}$ & $\mathbf{7 3 , 2 0}$ & $\mathbf{7 1 , 8 4}$ & $\mathbf{6 9 , 5 3}$ \\
\hline Químico & 9,65 & 8,95 & 8,35 & 8,72 & 10,28 \\
Metalúrgico & 2,39 & 2,79 & 3,51 & 4,60 & 5,82 \\
Termoplástico & 4,70 & 5,18 & 5,82 & 5,58 & 5,54 \\
Mecânico & 2,54 & 2,17 & 2,31 & 2,32 & 2,53 \\
Relojoeiro & 1,25 & 0,99 & 0,92 & 0,81 & 1,03 \\
\hline Subtotal 2 & $\mathbf{9 3 , 1 6}$ & $\mathbf{9 3 , 8 0}$ & $\mathbf{9 4 , 1 1}$ & $\mathbf{9 3 , 8 7}$ & $\mathbf{9 4 , 7 3}$ \\
\hline Outros* & $\mathbf{6 , 8 4}$ & $\mathbf{6 , 2 0}$ & 5,89 & 6,13 & 5,27 \\
\hline Total & $\mathbf{1 0 0 , 0 0}$ & $\mathbf{1 0 0 , 0 0}$ & $\mathbf{1 0 0 , 0 0}$ & $\mathbf{1 0 0 , 0 0}$ & $\mathbf{1 0 0 , 0 0}$ \\
\hline Fonte: Suframa & & & &
\end{tabular}

Fonte: Suframa

* inclui os setores de isqueiros, canetas, barbeadores descartáveis, bebidas, brinquedos, ótico, mineral não metálico e madeireiro.

Na edição de 03 de setembro de 2003, a Revista Veja apresentou uma reportagem relativa à Zona Franca de Manaus, em que abordava diversos aspectos positivos e negativos sobre o modelo. Dentre os diversos itens levantados, desde os aspectos sociais e ambientais até os financeiros e fiscais, um deles despertou a curiosidade quanto ao seu entendimento e formação: a afirmação de que "um televisor produzido na Zona Franca chega às lojas de São Paulo custando para o fabricante $18 \%$ menos do que outro, idêntico, feito fora de Manaus".

Além desse benefício de redução de preços para todos os consumidores brasileiros, segundo a reportagem da Revista Veja, Ribeiro (2008, p. 329) afirma que "os incentivos fiscais concedidos na Zona Franca de Manaus constituem primordial importância para a promoção do equilíbrio regional, incentivando e estimulando o crescimento da região amazônica." Acrescenta, ainda, que esses incentivos têm demonstrado um resultado positivo, por atender a função social do tributo no âmbito de sua abrangência, embora devam alcançar outros fins. 
Estudos mais complexos seriam necessários para analisar os efeitos dos incentivos fiscais no crescimento e desenvolvimento da região amazônica e, até mesmo, da cidade de Manaus, entretanto alguns dados merecem ser destacados.

O Apêndice 4 mostra o Produto Interno Bruto ${ }^{55}$ a preços correntes e o Produto Interno Bruto per capita das regiões e dos Estados brasileiros. No período pesquisado, 2003 a 2006, verifica-se elevado crescimento do Estado do Amazonas. Vale destacar o registro de que o PIB per capita amazonense é superior ao de todos os Estados das regiões Norte e Nordeste e de Estados tradicionais como Minas Gerais, Goiás e Mato Grosso.

A Tabela 10 corrobora o Apêndice 4 ao mostrar a variação percentual, entre o período de 2006 e 2003, do PIB a preços correntes e per capita das regiões e dos Estados brasileiros. Com exceção do Espírito Santo e Maranhão, nessa ordem, o Amazonas foi o Estado que apresentou a maior variação de crescimento no PIB per capita: 46,04\%. Com relação ao PIB absoluto a preços correntes, o Amazonas apresentou crescimento de 56,81\%, inferior apenas ao Espírito Santo.

Tabela 10 - Produto Interno Bruto a preços correntes e Produto Interno Bruto per capita, segundo as grandes regiões e unidades da federação - 2003 - 2006

\begin{tabular}{|c|c|c|c|c|c|c|}
\hline \multirow[b]{3}{*}{$\begin{array}{c}\text { Grandes Regiões e } \\
\text { Unidades da Federação }\end{array}$} & \multicolumn{6}{|c|}{ Produto Interno Bruto } \\
\hline & \multicolumn{2}{|l|}{2003} & \multicolumn{2}{|l|}{2006} & \multicolumn{2}{|c|}{ Variação 2006/2003 } \\
\hline & $\begin{array}{c}\text { A preços } \\
\text { correntes } \\
(1000 \mathrm{R} \$)\end{array}$ & $\begin{array}{c}\text { Per } \\
\text { capita } \\
(\mathrm{R} \$)\end{array}$ & $\begin{array}{c}\text { A preços } \\
\text { correntes } \\
(1000 \mathrm{R} \$)\end{array}$ & $\begin{array}{c}\text { Per } \\
\text { capita } \\
(\mathrm{R} \$)\end{array}$ & $\begin{array}{c}\text { A preços } \\
\text { correntes } \\
(1000 \\
\mathrm{R} \$) \\
\end{array}$ & $\begin{array}{c}\text { Per } \\
\text { capita } \\
(\mathrm{R} \$)\end{array}$ \\
\hline Norte & 81199581 & 5780 & 120013924 & 7989 & $47,80 \%$ & $38,23 \%$ \\
\hline Rondônia & 9750818 & 6594 & 13110092 & 8391 & $34,45 \%$ & $27,24 \%$ \\
\hline Acre & 3304771 & 5278 & 4834771 & 7041 & $46,30 \%$ & $33,41 \%$ \\
\hline Amazonas & 24977170 & 8100 & 39166314 & 11829 & $56,81 \%$ & $46,04 \%$ \\
\hline Roraima & 2737003 & 7455 & 3660153 & 9075 & $33,73 \%$ & $21,73 \%$ \\
\hline Pará & 29754565 & 4448 & 44375766 & 6241 & $49,14 \%$ & $40,31 \%$ \\
\hline Amapá & 3434107 & 6220 & 5260099 & 8543 & $53,17 \%$ & $37,35 \%$ \\
\hline Tocantins & 7241147 & 5784 & 9606730 & 7210 & $32,67 \%$ & $24,66 \%$ \\
\hline Nordeste & 217037426 & 4355 & 311174975 & 6029 & $43,37 \%$ & $38,44 \%$ \\
\hline Maranhão & 18483300 & 3112 & 28621445 & 4628 & $54,85 \%$ & $48,73 \%$ \\
\hline Piauí & 8777044 & 2978 & 12790396 & 4213 & $45,73 \%$ & $41,48 \%$ \\
\hline Ceará & 32565454 & 4145 & 46309884 & 5636 & $42,21 \%$ & $35,96 \%$ \\
\hline Rio Grande do Norte & 13515095 & 4626 & 20556655 & 6754 & $52,10 \%$ & $45,98 \%$ \\
\hline Paraíba & 14157834 & 3998 & 19953459 & 5507 & $40,94 \%$ & $37,74 \%$ \\
\hline
\end{tabular}

\footnotetext{
${ }^{55}$ Dados disponíveis até 2006.
} 


\begin{tabular}{|c|c|c|c|c|c|c|}
\hline \multirow[b]{2}{*}{ Pernambuco } & \multirow[b]{2}{*}{39308429} & \multirow[b]{2}{*}{4774} & \multirow[b]{2}{*}{55504917} & \multirow[b]{2}{*}{6528} & \multicolumn{2}{|c|}{ continuação } \\
\hline & & & & & $41,20 \%$ & $36,75 \%$ \\
\hline Alagoas & 11209511 & 3805 & 15753395 & 5164 & $40,54 \%$ & $35,72 \%$ \\
\hline Sergipe & 10873835 & 5718 & 15125895 & 7560 & $39,10 \%$ & $32,21 \%$ \\
\hline Bahia & 68146924 & 5031 & 96558929 & 6922 & $41,69 \%$ & $37,57 \%$ \\
\hline Sudeste & 947748381 & 12424 & 1345509830 & 16912 & $41,97 \%$ & $36,12 \%$ \\
\hline Minas Gerais & 148822788 & 7937 & 214813511 & 11028 & $44,34 \%$ & $38,95 \%$ \\
\hline Espírito Santo & 31063717 & 9425 & 52781902 & 15236 & $69,91 \%$ & $61,66 \%$ \\
\hline Rio de Janeiro & 188014960 & 12514 & 275362726 & 17695 & $46,46 \%$ & $41,41 \%$ \\
\hline São Paulo & 579846916 & 14788 & 802551691 & 19548 & $38,41 \%$ & $32,19 \%$ \\
\hline Sul & 300858677 & 11440 & 386736960 & 14162 & $28,54 \%$ & $23,79 \%$ \\
\hline Paraná & 109458876 & 10935 & 136680839 & 13158 & $24,87 \%$ & $20,33 \%$ \\
\hline Santa Catarina & 66848534 & 11764 & 93173498 & 15638 & $39,38 \%$ & $32,92 \%$ \\
\hline Rio Grande do Sul & 124551267 & 11742 & 156882623 & 14310 & $25,96 \%$ & $21,87 \%$ \\
\hline Centro-Oeste & 153103630 & 12228 & 206360858 & 15552 & $34,79 \%$ & $27,18 \%$ \\
\hline Mato Grosso do Sul & 19273681 & 8772 & 24355395 & 10599 & $26,37 \%$ & $20,82 \%$ \\
\hline Mato Grosso & 27888658 & 10347 & 35284471 & 12350 & $26,52 \%$ & $19,36 \%$ \\
\hline Goiás & 42836390 & 7937 & 57090883 & 9962 & $33,28 \%$ & $25,52 \%$ \\
\hline Distrito Federal & 63104900 & 28282 & 89630109 & 37600 & $42,03 \%$ & $32,94 \%$ \\
\hline
\end{tabular}

Fonte: IBGE. Disponível em: <http: www.ibge.gov.br >. Acesso em: 15/12/2008

No Apêndice 5, são apresentados o Produto Interno Bruto a preços correntes e o Produto Interno Bruto per capita das principais capitais brasileiras. No período pesquisado, 2003 a 2006, observa-se que apenas os PIB per capita de Distrito Federal, São Paulo, Porto Alegre e Rio de Janeiro, nessa ordem, superavam o da cidade de Manaus. Capitais tradicionais, como Belo Horizonte e Curitiba, apresentam valores inferiores e no caso das capitais Salvador e Fortaleza, o PIB per capita de Manaus chega a ser mais do que o dobro.

A Tabela 11, a seguir, mostra a variação do Produto Interno Bruto a preços correntes e per capita das principais capitais brasileiras no período de 2003 a 2006, na qual se observa que, dentre as capitais pesquisadas, Manaus foi a que apresentou maior crescimento relativo. 
Tabela 11 - Crescimento do Produto Interno Bruto das principais cidades brasileiras - 2006/2003

\begin{tabular}{|c|c|c|c|c|c|c|}
\hline \multirow{3}{*}{ Cidades e Regiões } & \multicolumn{6}{|c|}{ Produto Interno Bruto } \\
\hline & \multicolumn{2}{|c|}{2003} & \multicolumn{2}{|l|}{2006} & \multicolumn{2}{|c|}{ Variação 2006/2003 } \\
\hline & $\begin{array}{c}\text { A preços } \\
\text { correntes } \\
(1000 \mathrm{R} \$)\end{array}$ & $\begin{array}{c}\text { Per } \\
\text { capita } \\
(\mathrm{R} \$)\end{array}$ & $\begin{array}{c}\text { A preços } \\
\text { correntes } \\
(1000 \mathrm{R} \$)\end{array}$ & $\begin{array}{c}\text { Per } \\
\text { capita } \\
(\mathrm{R} \$)\end{array}$ & $\begin{array}{l}\text { A preços } \\
\text { correntes } \\
(1000 \mathrm{R} \$)\end{array}$ & $\begin{array}{c}\text { Per } \\
\text { capita } \\
(\mathrm{R} \$)\end{array}$ \\
\hline \multicolumn{7}{|l|}{ Norte } \\
\hline Manaus & 20640758 & 13260 & 31916257 & 18902 & $54,63 \%$ & $42,54 \%$ \\
\hline Belém & 8838679 & 6496 & 12520322 & 8765 & $41,65 \%$ & $34,93 \%$ \\
\hline \multicolumn{7}{|l|}{ Nordeste } \\
\hline Fortaleza & 15303784 & 6681 & 22537716 & 9325 & $47,27 \%$ & $39,57 \%$ \\
\hline Recife & 13098429 & 8894 & 18318451 & 12091 & $39,85 \%$ & $35,95 \%$ \\
\hline Salvador & 16770662 & 6480 & 24072400 & 8870 & $43,54 \%$ & $36,88 \%$ \\
\hline \multicolumn{7}{|l|}{ Sudeste } \\
\hline Belo Horizonte & 23197223 & 9973 & 32725361 & 13636 & $41,07 \%$ & $36,72 \%$ \\
\hline São Paulo & 209555133 & 19494 & 282852338 & 25675 & $34,98 \%$ & $31,70 \%$ \\
\hline Rio de Janeiro & 95751484 & 15935 & 127956075 & 20851 & $33,63 \%$ & $30,85 \%$ \\
\hline \multicolumn{7}{|l|}{ Sul } \\
\hline Curitiba & 23828224 & 14047 & 32153307 & 17977 & $34,94 \%$ & $27,98 \%$ \\
\hline Porto Alegre & 21871109 & 15577 & 30116002 & 20900 & $37,70 \%$ & $34,18 \%$ \\
\hline \multicolumn{7}{|l|}{ Centro-Oeste } \\
\hline Goiânia & 10757548 & 9258 & 15872191 & 13006 & $47,54 \%$ & $40,48 \%$ \\
\hline Brasília & 63104900 & 28282 & 89630109 & 37600 & $42,03 \%$ & $32,94 \%$ \\
\hline
\end{tabular}

Fonte: IBGE. Disponível em: <http:www.ibge.gov.br>. Acesso em: 15/12/2008

Com relação à participação do PIB a preços correntes, mostrado apenas para o ano de 2006, na Tabela 12, observam-se as seguintes peculiaridades:

- Com exceção do Distrito Federal, que, na realidade, é representado por um conjunto de cidades, Manaus é a capital que apresenta a maior concentração do PIB em relação ao Estado: 81,49\%;

- $\quad$ Com exceção do Distrito Federal, Manaus é a capital que apresenta a maior participação do PIB na região: $26,59 \%$ contra $21,02 \%$ da cidade de São Paulo;

- Com exceção de São Paulo, Rio de Janeiro e Distrito Federal, que possuem uma participação de $11,94 \%, 5,40 \%$ e 3,78\%, respectivamente, no PIB do País, Manaus aparece logo em seguida com 1,35\%, disputando o 4\%. lugar com capitais tradicionais como Belo Horizonte e Curitiba. 
Tabela 12 - Produto Interno Bruto a preços correntes e participação das principais cidades brasileiras nas regiões e no país - 2006

\begin{tabular}{|c|c|c|c|c|c|c|}
\hline \multirow[b]{2}{*}{$\begin{array}{c}\text { Grandes Regiões e } \\
\text { Unidades da } \\
\text { Federação }\end{array}$} & \multirow[b]{2}{*}{$\begin{array}{l}\text { Principais } \\
\text { cidades } \\
\text { brasileiras }\end{array}$} & \multicolumn{5}{|c|}{$\begin{array}{l}\text { Produto Interno Bruto - } 2006 \\
(1000000 \mathrm{R} \$)\end{array}$} \\
\hline & & $\begin{array}{l}\text { Região e } \\
\text { Estado a } \\
\text { preços } \\
\text { correntes } \\
\end{array}$ & $\begin{array}{c}\text { Cidade a } \\
\text { preços } \\
\text { correntes }\end{array}$ & $\begin{array}{c}\text { Participação } \\
\text { \% da cidade } \\
\text { no Estado }\end{array}$ & $\begin{array}{l}\text { Participação } \\
\text { \% da cidade } \\
\text { na Região }\end{array}$ & \begin{tabular}{|c|}
$\begin{array}{c}\text { Participação } \\
\% \text { da cidade } \\
\text { e região no } \\
\text { Brasil }\end{array}$ \\
\end{tabular} \\
\hline Norte & & 120.014 & & & & $5,06 \%$ \\
\hline Amazonas & Manaus & 39.166 & 31916 & 81,49 & 26,59 & $1,35 \%$ \\
\hline Pará & Belém & 44.376 & 12520 & 28,21 & 10,43 & $0,53 \%$ \\
\hline Rondônia & Porto Velho & 13.110 & 3763 & 28,70 & 3,14 & $0,16 \%$ \\
\hline Nordeste & & 311.175 & & & & $13,13 \%$ \\
\hline Bahia & Salvador & 96.559 & 24072 & 24,93 & $7,74 \%$ & $1,02 \%$ \\
\hline Ceará & Fortaleza & 46.310 & 22538 & 48,67 & $7,24 \%$ & $0,95 \%$ \\
\hline Pernambuco & Recife & 55.505 & 18318 & 33,00 & $5,89 \%$ & $0,77 \%$ \\
\hline Maranhão & São Luís & 28.621 & 11217 & 39,19 & $3,60 \%$ & $0,47 \%$ \\
\hline Bahia & Camaçari & 96.559 & 9534 & 9,87 & $3,06 \%$ & $0,40 \%$ \\
\hline Sudeste & & 1.345 .510 & & & & $56,78 \%$ \\
\hline São Paulo & São Paulo & 802.552 & 282852 & 35,24 & $21,02 \%$ & $11,94 \%$ \\
\hline Rio de Janeiro & Rio de Janeiro & 275.363 & 127956 & 46,47 & $9,51 \%$ & $5,40 \%$ \\
\hline Minas Gerais & Belo Horizonte & 214.814 & 32725 & 15,23 & $2,43 \%$ & $1,38 \%$ \\
\hline São Paulo & Guarulhos & 802.552 & 25664 & 3,20 & $1,91 \%$ & $1,08 \%$ \\
\hline São Paulo & Barueri & 802.552 & 25484 & 3,18 & $1,89 \%$ & $1,08 \%$ \\
\hline São Paulo & Campinas & 802.552 & 23625 & 2,94 & $1,76 \%$ & $1,00 \%$ \\
\hline Rio de Janeiro & Campos & 275.363 & 23115 & 8,39 & $1,72 \%$ & $0,98 \%$ \\
\hline Rio de Janeiro & Duque de Caxias & 275.363 & 22565 & 8,19 & $1,68 \%$ & $0,95 \%$ \\
\hline São Paulo & São B. Campo & 802.552 & 20572 & 2,56 & $1,53 \%$ & $0,87 \%$ \\
\hline Minas Gerais & Betim & 214.814 & 18732 & 8,72 & $1,39 \%$ & $0,79 \%$ \\
\hline Sul & & 386.737 & & & & $16,32 \%$ \\
\hline Paraná & Curitiba & 136.681 & 32153 & 23,52 & $8,31 \%$ & $1,36 \%$ \\
\hline Rio Grande do Sul & Porto Alegre & 156.883 & 30116 & 19,20 & $7,79 \%$ & $1,27 \%$ \\
\hline Santa Catarina & Joinville & 93.173 & 10684 & 11,47 & $2,76 \%$ & $0,45 \%$ \\
\hline Rio Grande do Sul & Canoas & 156.883 & 9607 & 6,12 & $2,48 \%$ & $0,41 \%$ \\
\hline Rio Grande do Sul & Caixas do Sul & 156.883 & 8621 & 5,50 & $2,23 \%$ & $0,36 \%$ \\
\hline Centro-Oeste & & 206.361 & & & & $8,71 \%$ \\
\hline Distrito Federal & Brasília & 89.630 & 89630 & 100,00 & $43,43 \%$ & $3,78 \%$ \\
\hline Goiás & Goiânia & 57.091 & 15872 & 27,80 & $7,69 \%$ & $0,67 \%$ \\
\hline Mato Grosso do Sul & Campo Grande & 24.355 & 7840 & 32,19 & $3,80 \%$ & $0,33 \%$ \\
\hline Mato Grosso & Cuiabá & 35.284 & 7190 & 20,38 & $3,48 \%$ & $0,30 \%$ \\
\hline \multicolumn{2}{|l|}{ Total Brasil } & 2.369 .797 & & & & $100,00 \%$ \\
\hline
\end{tabular}

Fonte: IBGE. Disponível em: <http:www.ibge.gov.br>. Acesso em: 15/12/2008

No que diz respeito à arrecadação de tributos federais, embora a Zona Franca de Manaus seja um regime industrial baseado em incentivos fiscais especiais, os dados das Tabelas 13, 14 e 
15 merecem ser analisados. Ao analisar a participação relativa de cada Estado na arrecadação total da região a que pertence, a Tabela 13 mostra que o Estado do Amazonas apresenta a maior participação, correspondente a $61,27 \%$, com exceção do Distrito Federal que, por características peculiares como a concentração de órgãos públicos federais, é responsável por $87,02 \%$ da arrecadação federal da região na qual está inserido.

Deve-se destacar que a participação de 61,27 \% do Estado do Amazonas no total de arrecadação de tributos federais na Região Norte, supera as participações de Estados tradicionais como São Paulo, Rio de Janeiro e Rio Grande do Sul nas suas respectivas regiões.

Tabela 13 - Arrecadação de tributos federais, arrecadação de tributos federais per capita e participação das unidades da federação no total por região - 2006

\begin{tabular}{|c|c|c|c|c|c|}
\hline \multirow{2}{*}{$\begin{array}{c}\text { Grandes Regiões e } \\
\text { Unidades da } \\
\text { Federação }\end{array}$} & \multicolumn{5}{|c|}{ Valores 2006} \\
\hline & 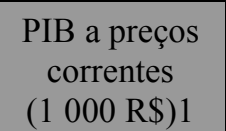 & $\begin{array}{l}\text { População } \\
\text { (1000)1 }\end{array}$ & $\begin{array}{l}\text { Arrecadação em } \\
\quad(1000 \mathrm{R} \$) 2\end{array}$ & $\begin{array}{l}\text { Participação } \\
\text { \% na região }\end{array}$ & $\begin{array}{c}\text { Arrecadação } \\
\text { per capta } \\
(1000 \mathrm{R} \$)\end{array}$ \\
\hline Norte & 120013924 & $15.022,06$ & 7.995 .987 & - & 532 \\
\hline Rondônia & 13110092 & $1.562,42$ & 460.903 & $5,76 \%$ & 295 \\
\hline Acre & 4834771 & 686,65 & 159.822 & $2,00 \%$ & 233 \\
\hline Amazonas & 39166314 & $3.311,03$ & 4.899 .466 & $61,27 \%$ & 1.480 \\
\hline Roraima & 3660153 & 403,34 & 120.299 & $1,50 \%$ & 298 \\
\hline Pará & 44375766 & $7.110,46$ & 1.855 .834 & $23,21 \%$ & 261 \\
\hline Amapá & 5260099 & 615,72 & 156.839 & $1,96 \%$ & 255 \\
\hline Tocantins & 9606730 & $1.332,44$ & 342.824 & $4,29 \%$ & 257 \\
\hline Nordeste & 311174975 & $51.609,01$ & 21.339.617 & - & 413 \\
\hline Maranhão & 28621445 & $6.184,54$ & 1.540 .857 & $7,22 \%$ & 249 \\
\hline Piauí & 12790396 & $3.036,29$ & 532.231 & $2,49 \%$ & 175 \\
\hline Ceará & 46309884 & $8.217,09$ & 3.470 .408 & $16,26 \%$ & 422 \\
\hline Rio Grande do Norte & 20556655 & $3.043,76$ & 937.452 & $4,39 \%$ & 308 \\
\hline Paraíba & 19953459 & $3.623,22$ & 914.624 & $4,29 \%$ & 252 \\
\hline Pernambuco & 55504917 & $8.502,60$ & 4.623 .922 & $21,67 \%$ & 544 \\
\hline Alagoas & 15753395 & $3.050,65$ & 653.327 & $3,06 \%$ & 214 \\
\hline Sergipe & 15125895 & $2.000,74$ & 711.908 & $3,34 \%$ & 356 \\
\hline Bahia & 96558929 & $13.950,16$ & 7.954 .888 & $37,28 \%$ & 570 \\
\hline Sudeste & 1345509830 & $79.561,07$ & 279.165 .118 & - & 3.509 \\
\hline Minas Gerais & 214813511 & $19.479,36$ & 20.391 .580 & $7,30 \%$ & 1.047 \\
\hline Espírito Santo & 52781902 & $3.464,28$ & 6.436 .296 & $2,31 \%$ & 1.858 \\
\hline Rio de Janeiro & 275362726 & $15.561,72$ & 89.662 .707 & $32,12 \%$ & 5.762 \\
\hline São Paulo & 802551691 & $41.055,73$ & 162.674 .535 & $58,27 \%$ & 3.962 \\
\hline
\end{tabular}




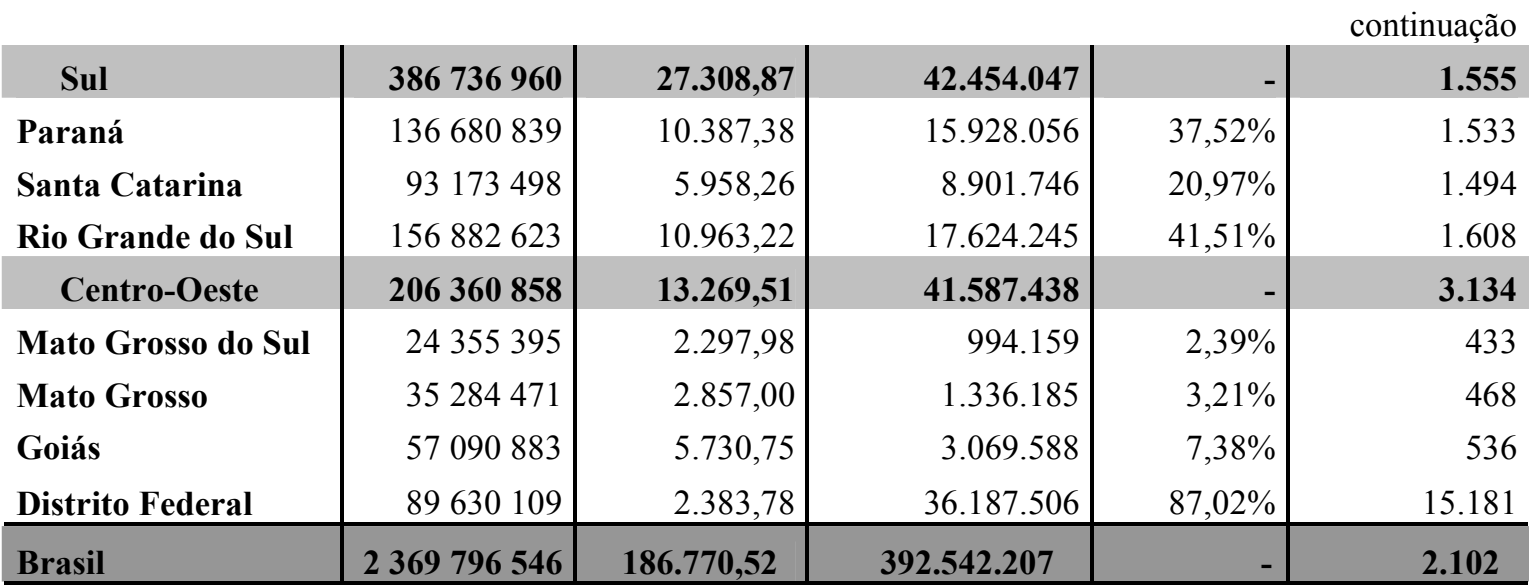

1) Fonte: IBGE. Disponível em: <http:www.ibge.gov.br>. Acesso em: 15/12/2008

2) Fonte: Secretaria da Receita Federal do Brasil. Disponível em: $<$ http:www.receita.fazenda.gov.br $>$.

Acesso em: 12/12/2008

A Tabela 14 mostra a relação entre o valor total de tributos federais arrecadado por alguns Estados brasileiros e o seu respectivo PIB a preços correntes. Dos principais Estados de cada região, observa-se que o Amazonas apresenta uma arrecadação de 12,51\% do PIB, em 2006, níveis inferiores apenas ao Distrito Federal, São Paulo e Rio de Janeiro. Vale destacar que esse percentual de arrecadação em relação ao PIB é superior a Estados tradicionais como todos da região sul e nordeste.

Tabela 14 - Relação entre arrecadação e PIB de alguns Estados brasileiros - 2003 - 2006

\begin{tabular}{|c|c|c|c|c|}
\hline \multirow{2}{*}{ Regiões e Estados } & \multicolumn{4}{|c|}{ Percentual } \\
\hline & $2003^{(1)}$ & 2004 & 2005 & 2006 \\
\hline \multicolumn{5}{|l|}{ Norte } \\
\hline Amazonas & $11,54 \%$ & $14,32 \%$ & $12,42 \%$ & $12,51 \%$ \\
\hline Pará & $5,61 \%$ & $4,61 \%$ & $4,45 \%$ & $4,18 \%$ \\
\hline \multicolumn{5}{|l|}{ Nordeste } \\
\hline Bahia & $6,32 \%$ & $7,41 \%$ & $8,49 \%$ & $8,24 \%$ \\
\hline Ceará & $6,44 \%$ & $7,50 \%$ & $7,99 \%$ & $7,49 \%$ \\
\hline Pernambuco & $7,97 \%$ & $9,17 \%$ & $9,18 \%$ & $8,33 \%$ \\
\hline \multicolumn{5}{|l|}{ Sudeste } \\
\hline São Paulo & $18,67 \%$ & $20,49 \%$ & $20,46 \%$ & $20,27 \%$ \\
\hline Rio de Janeiro & $20,26 \%$ & $31,38 \%$ & $33,13 \%$ & $32,56 \%$ \\
\hline Minas Gerais & $8,60 \%$ & $9,22 \%$ & $10,07 \%$ & $9,49 \%$ \\
\hline \multicolumn{5}{|l|}{ Sul } \\
\hline Paraná & $9,51 \%$ & $11,40 \%$ & $11,70 \%$ & $11,65 \%$ \\
\hline Rio Grande do Sul & $9,42 \%$ & $11,95 \%$ & $11,96 \%$ & $11,23 \%$ \\
\hline \multicolumn{5}{|l|}{ Centro-Oeste } \\
\hline Distrito Federal & $43,08 \%$ & $48,28 \%$ & $43,88 \%$ & $40,37 \%$ \\
\hline Total Brasil & $14,10 \%$ & $16,61 \%$ & $16,96 \%$ & $16,56 \%$ \\
\hline
\end{tabular}

(1) Inclui apenas as receitas administradas pela Receita Federal do Brasil.

Fonte: IBGE. Disponível em: <http:www.receita.fazenda.gov.br>. Acesso em: 11/12/2008 
Por fim, com relação à arrecadação de tributos, a Tabela 15 mostra o valor arrecadado de tributos federais por alguns Estados brasileiros, no período de 2003 a 2007. Dos Estados selecionados, apenas Rio de Janeiro e Bahia apresentaram maiores taxas de crescimento.

Tabela 15 - Arrecadação de tributos federais por alguns Estados Brasileiros - 2003 - 2007

\begin{tabular}{|c|c|c|c|c|c|c|}
\hline \multirow{2}{*}{$\begin{array}{c}\text { Regiões e } \\
\text { Estados }\end{array}$} & \multicolumn{5}{|c|}{ Valor da Arrecadação - 1.000 RS } & \multirow{2}{*}{$\begin{array}{c}\text { Variação } \\
\% \\
2007 / 2003\end{array}$} \\
\hline & $2003^{(1)}$ & 2004 & 2005 & 2006 & 2007 & \\
\hline \multicolumn{7}{|l|}{ Norte } \\
\hline Amazonas & 2.883 .492 & 4.340 .150 & 4.141 .967 & 4.899 .466 & 5.633 .289 & $95,36 \%$ \\
\hline Pará & 1.669 .035 & 1.637 .843 & 1.740 .245 & 1.855 .834 & 2.119 .457 & $26,99 \%$ \\
\hline \multicolumn{7}{|l|}{ Nordeste } \\
\hline Bahia & 4.307 .234 & 5.862 .513 & 7.721 .058 & 7.954 .888 & 8.720 .104 & $102,45 \%$ \\
\hline Ceará & 2.096 .286 & 2.766 .453 & 3.269 .685 & 3.470 .408 & 3.928 .745 & $87,41 \%$ \\
\hline Pernambuco & 3.132 .902 & 4.036 .687 & 4.581 .050 & 4.623 .922 & 5.658 .377 & $80,61 \%$ \\
\hline \multicolumn{7}{|l|}{ Sudeste } \\
\hline São Paulo & 108.268 .787 & 131.820 .389 & 148.739 .238 & 162.674 .535 & 190.237 .840 & $75,71 \%$ \\
\hline Rio de Janeiro & 38.088 .733 & 69.954 .006 & 81.839 .919 & 89.662 .707 & 94.328 .531 & $147,65 \%$ \\
\hline Minas Gerais & 12.793 .145 & 16.350 .005 & 19.406 .023 & 20.391 .580 & 25.179 .794 & $96,82 \%$ \\
\hline \multicolumn{7}{|l|}{ Sul } \\
\hline Paraná & 10.411 .949 & 13.954 .084 & 14.820 .145 & 15.928 .056 & 19.808 .484 & $90,25 \%$ \\
\hline Rio G. do Sul & 11.726 .695 & 16.467 .435 & 17.247 .623 & 17.624 .245 & 19.818 .158 & $69,00 \%$ \\
\hline \multicolumn{7}{|l|}{ Centro-Oeste } \\
\hline Distrito Federal & 27.186 .197 & 34.144 .011 & 35.332 .878 & 36.187 .506 & 40.990 .568 & $50,78 \%$ \\
\hline Total Brasil & 239.658.993 & 322.554 .780 & 364.136 .084 & 392.542 .207 & 448.884.202 & $87,30 \%$ \\
\hline
\end{tabular}

Com os dados aqui apresentados não se busca discutir o nível de desenvolvimento, de riqueza do Amazonas ou outra análise mais aprofundada, uma vez que seria imprescindível analisar sob a ótica da qualidade de vida, nível de emprego, índice de desenvolvimento humano, dentre outros indicadores, entretanto os dados permitem afirmar, dentre outras, que:

- A Zona Franca de Manaus é responsável pelo elevado crescimento econômico do Estado do Amazonas; 
- A Zona Franca de Manaus faz com que mais de 80\% do PIB do Estado do Amazonas esteja concentrado na capital Manaus;

- O Estado do Amazonas, mesmo hospedando um modelo industrial baseado em incentivos fiscais, é responsável por mais de $61 \%$ da arrecadação de tributos federais da Região Norte;

- Manaus tornou-se a capital com o 4ํㅡㄹ maior PIB do Brasil e

- O Estado do Amazonas arrecada mais tributos em relação ao PIB do que qualquer Estado das regiões Norte, Nordeste e Sul.

Após a apresentação e análise dos dados sobre Produto Interno Bruto, Produto Interno Bruto per capita e dados sobre a arrecadação de tributos federais, torna-se fundamental a análise dos principais incentivos fiscais envolvidos no modelo industrial Zona Franca de Manaus.

\subsection{Principais incentivos fiscais envolvidos}

A Zona Franca de Manaus é um modelo industrial que se caracteriza como uma área de livre comércio de importação e de exportação e de incentivos fiscais especiais, estabelecida com a finalidade de criar no interior da Amazônia um centro industrial, comercial e agropecuário, dotado de condições econômicas que permitam seu desenvolvimento, em face dos fatores locais e da grande distância em que se encontram os centros consumidores de seus produtos, de acordo com a definição dada pelo art. 1ํ do Decreto-lei n. 288, de 28 de fevereiro de 1967.

Dentre os diversos incentivos fiscais e extrafiscais concedidos às empresas instaladas na Zona Franca de Manaus, interessam ao escopo do presente trabalho apenas os incentivos fiscais e, mesmo assim, somente aqueles destinados às industriais estabelecidas naquela área, incidentes sobre o imposto de importação (II), o imposto sobre produtos industrializados (IPI), o imposto sobre circulação de mercadorias e serviços (ICMS) e as contribuições para o Programa de Integração Social (PIS) e para o Financiamento da Seguridade Social (COFINS), embora essas últimas não se caracterizem como incentivo fiscal diferenciais e representativas e com aplicação pacífica. 
A seguir, são apresentados os conceitos, as definições e a operacionalização de cada um dos tributos os quais são objeto de incentivos fiscais.

\subsubsection{Imposto de importação}

Um dos principais incentivos fiscais concedidos às empresas instaladas na Zona Franca de Manaus diz respeito ao Imposto de Importação. A legislação preconiza que, por época da importação de mercadorias, aqui compreendidas desde as matérias-primas até os produtos finais, a entrada naquela região pode ser realizada com a suspensão de tributos, com exceção de: armas e munições; fumo e produtos de tabacaria; bebidas alcoólicas; automóveis de passageiros e produtos de perfumaria e de toucador e preparações cosméticas.

Para as mercadorias importadas, consumidas ou industrializadas naquela região, a legislação trata-as como isenção de tributos, desde que lá permaneçam e que sejam utilizadas para os fins a que foram importadas.

Entretanto, de acordo com o art. 457, do Decreto-lei n. 4.543/2002 (RA), as mercadorias estrangeiras importadas para a Zona Franca de Manaus, quando dessa saírem para outros pontos do território aduaneiro, ficam sujeitas ao pagamento de todos os impostos exigíveis sobre importações do exterior.

O parágrafo único desse mesmo artigo excetua do pagamento dos impostos, as seguintes hipóteses:

- $\quad$ bagagem de viajante;

- internação de produtos industrializados na Zona Franca de Manaus com insumos estrangeiros;

- $\quad$ saída, para a Amazônia Ocidental, de produtos compreendidos na pauta da Portaria Interministerial n. 300/96 e

- $\quad$ saída de mercadorias para as áreas de livre comércio, observada a legislação específica.

O conceito de internação de mercadorias significa a entrada no restante do território aduaneiro (todo o território nacional) de mercadoria saída da Zona Franca de Manaus. Esse 
entendimento passa a ser importante para a compreensão do cálculo e pagamento dos tributos federais envolvidos.

A base da matriz de cálculo do imposto de importação considera que, quando os produtos industrializados na Zona Franca de Manaus dela saírem para qualquer ponto do território aduaneiro, estarão sujeitos ao pagamento do imposto de importação relativo a matériasprimas, produtos intermediários, materiais secundários e de embalagem, componentes e outros insumos de origem estrangeira neles empregados, calculado o tributo mediante coeficiente de redução de sua alíquota ad valorem, desde que atendam nível de industrialização local compatível com processo produtivo básico determinado para aquele segmento industrial.

Esse coeficiente de redução do imposto de importação será obtido mediante a aplicação da seguinte fórmula:

$$
I N=\frac{C C N+C M O}{C C N+C C I+C M O} \quad \text { Equação } 01
$$

em que:

$I N$ = índice de nacionalização;

$C C N=$ CUSTO DOS COMPONENTES NACIONAIS: soma dos custos dos componentes nacionais representados pela soma dos valores de matérias-primas, produtos intermediários, materiais secundários e de embalagem, componentes e outros insumos de produção nacional; $C M O=C U S T O$ DA MÃO DE OBRA DIRETA: soma dos custos da mão de obra e encargos empregada no processo produtivo e

$C C I=C U S T O D O S$ COMPONENTES IMPORTADOS: soma dos valores de matérias-primas, produtos intermediários, materiais secundários e de embalagem, componentes e outros insumos de origem estrangeira.

O índice de nacionalização calculado pela Equação 01 permanece em vigor até os dias de hoje e significa que, quanto maior for esse índice, maior será a parcela de componentes nacionais utilizada na estrutura de custos do produto, maior será o índice de redução e menor será o imposto de importação a pagar. 
Após o advento da Lei n. 8.387/1991, apenas duas categorias de produtos são obrigadas a calcular a redução dessa forma: i) os veículos automóveis, tratores e outros veículos terrestres, e suas partes e peças e ii) os bens do setor de informática. Os demais, em função do art. 7o da referida Lei, possuem um índice de redução fixo de $88 \%$ (oitenta e oito por cento).

A fim de que sejam reforçados os conceitos acima discutidos, exemplos numéricos tornam-se necessários. São apresentados cálculos de três produtos que, produzidos na Zona Franca de Manaus com incentivos fiscais, ao serem vendidos para o resto do Brasil, são obrigados a recolher o imposto de importação reduzido.

Os valores demonstrados referem-se a dois produtos com redutor fixo e um com redutor variável, calculado de acordo com o índice de nacionalização. São valores reais com a simplificação apenas na quantidade de componentes para fins ilustrativos didáticos.

O Quadro 9 apresenta o cálculo do imposto de importação reduzido para um televisor em cores, produto não enquadrado como veículo automóvel de passeio nem como bens do setor de informática, ou seja, no qual incide o redutor fixo de $88 \%$ (oitenta e oito por cento) do imposto de importação.

Quadro 9- Demonstração de cálculo do imposto de importação reduzido de um Televisor 21'- redutor fixo

\begin{tabular}{|l|r|r|r|r|r|}
\hline \multicolumn{1}{|c|}{$\begin{array}{c}\text { Componentes } \\
\text { (1) }\end{array}$} & $\begin{array}{c}\text { Quantidade } \\
\text { (2) }\end{array}$ & $\begin{array}{c}\text { Valor } \\
\text { Unitário } \\
\text { US\$ (3) }\end{array}$ & $\begin{array}{c}\text { Valor Total } \\
\text { US\$ (4) }\end{array}$ & $\begin{array}{c}\text { Alíquota \%o II (5) } \\
\text { do }\end{array}$ & $\begin{array}{c}\text { Valor do II } \\
\text { Suspenso } \\
\text { US\$ (6) }\end{array}$ \\
\hline A - ESPECIFICAÇÃO DOS COMPONENTES IMPORTADOS & \multicolumn{3}{|c|}{} \\
\hline 1. Transformador de saída & 1 & 5,7103 & 5,7103 & 2,50 & 0,142758 \\
2. Sintonizador de RF & 1 & 3,6632 & 3,6632 & 18,50 & 0,677692 \\
3. Placa de circuitos impressos & 1 & 1,4343 & 1,4343 & 12,50 & 0,179288 \\
4. Circuito integrado monolítico & 1 & 1,3019 & 1,3019 & 12,00 & 0,156228 \\
5. Capacitor fixo, eletrolítico & 2 & 0,5838 & 1,1676 & 18,50 & 0,216006 \\
6. Relê para tensão & 1 & 0,2416 & 0,2416 & 18,50 & 0,044696 \\
7. Resistor fixo, de fio & 1 & 0,1856 & 0,1856 & 18,50 & 0,034336 \\
8. Capacitor elétrico & 1 & 0,1510 & 0,1510 & 18,50 & 0,027935 \\
9. Outros (7) & 47 & $\mathbf{D i v e r s o s}$ & 34,0081 & $\mathbf{D i v e r s o s}$ & 4,673691 \\
\hline TOTAL & $\mathbf{5 5}$ & & $\mathbf{4 7 , 8 6 3 6}$ & & $\mathbf{6 , 1 5 2 6 2 9}$ \\
\hline
\end{tabular}




\begin{tabular}{|l|r|r|r|r|}
\hline B - ESPECIFICAÇÃO DOS COMPONENTES NACIONAIS & \\
\hline 1. Cinescópio & 1 & 65,9740 & 65,9740 & \\
2. Gabinete & 1 & 4,7511 & 4,7511 & \\
3. Tampa traseira & 1 & 3,7551 & 3,7551 & \\
4. Conjunto calço & 1 & 1,9950 & 1,9950 & \\
5. Caixa de embalagem & 1 & 1,2644 & 1,2644 & \\
6. Filtro de linha & 1 & 0,4448 & 0,4448 & \\
7. Cabo de força & 1 & 0,3595 & 0,3595 & \\
8. Chassi frame & 1 & 0,1725 & 0,1725 & \\
9. Outros (8) & 314 & Diversos & 8,9827 & \\
\hline TOTAL & $\mathbf{3 2 2}$ & $\mathbf{8 7 , 6 9 9 1}$ & \\
\hline C - CUSTO DA MÃO DE OBRA EM US\$ (9) & & \\
\hline D - CUSTO TOTAL (A + B +C) & $\mathbf{1 3 5 , 5 6 2 7}$ & $\mathbf{8 8 , 0 0 \%}$ \\
\hline COEFICIENTE DE REDUÇÃO DO II - FIXO (9) & & $\mathbf{6 , 1 5 2 6 2 9}$ \\
\hline Valor do Imposto de Importação em US\$ Suspenso (Sem Redução) & \\
\hline Valor da redução do Imposto de Importação em US\$ & & \\
\hline Valor do Imposto de Importação reduzido em US\$ (a pagar) & & \\
\hline
\end{tabular}

O Quadro 10 demonstra o cálculo do imposto de importação reduzido para uma motocicleta modelo 125 , produto não enquadrado como veículo automóvel de passeio nem como bens do setor de informática, ou seja, no qual incide o redutor fixo de $88 \%$ (oitenta e oito por cento) do imposto de importação.

Quadro 10 - Demonstração de cálculo do imposto de importação reduzido de uma motocicleta, modelo 125 - redutor fixo

\begin{tabular}{|c|c|c|c|c|c|}
\hline $\begin{array}{c}\text { Componentes } \\
\text { (1) } \\
\end{array}$ & $\begin{array}{c}\text { Quantidade } \\
\text { (2) } \\
\end{array}$ & $\begin{array}{c}\text { Valor } \\
\text { Unitário } \\
\text { US\$ (3) } \\
\end{array}$ & $\begin{array}{c}\text { Valor Total } \\
\text { US\$ (4) } \\
\end{array}$ & $\begin{array}{c}\text { Alíquota \% } \\
\text { do II (5) }\end{array}$ & $\begin{array}{c}\text { Valor do II } \\
\text { Suspenso } \\
\text { US\$ (6) } \\
\end{array}$ \\
\hline \multicolumn{6}{|c|}{ A - ESPECIFICAÇÃO DOS COMPONENTES IMPORTADOS } \\
\hline 1. Carburador & 1 & 24,3215 & 24,3215 & 18,50 & 4,499478 \\
\hline 2. Eixo do balancim & 1 & 14,3820 & 14,3820 & 18,50 & 2,660670 \\
\hline 3. Velocímetro sem fiação & 1 & 13,2747 & 13,2747 & 20,50 & 2,721314 \\
\hline 4. Acumulador elétrico & 1 & 10,0641 & 10,0641 & 20,50 & 2,063141 \\
\hline 5. Eixo do balancim & 1 & 7,8545 & 7,8545 & 18,50 & 1,453083 \\
\hline 6. Biela para motor & 1 & 6,5300 & 6,5300 & 16,50 & 1,077450 \\
\hline 7. Coroa de corrente de transmissão & 1 & 4,8592 & 4,8592 & 18,50 & 0,898952 \\
\hline 8. Coroa da corrente & 1 & 4,8592 & 4,8592 & 18,50 & 0,898952 \\
\hline 9. Outros (7) & 71 & Diversos & 88,4813 & Diversas & 15,851008 \\
\hline TOTAL & 79 & & 174,6265 & & 32,124046 \\
\hline
\end{tabular}


continuação

\section{B - ESPECIFICAÇÃO DOS COMPONENTES NACIONAIS}

1. Módulo guidão

2. Conjunto roda dianteira

3. Conjunto gerador

4. Conjunto embreagem

5. Conjunto escapamento

6. Conjunto transmissão secundária

7. Conjunto painel freio

8. Braço Oscilante

9. Outros (8)

TOTAL

C - CUSTO DA MÃO DE OBRA EM US\$ (9)

D - CUSTO TOTAL $(A+B+C)$

14,1742

114,1742

37,6005

37,6005

32,7939

32,7939

23,9368

23,9368

23,4428

23,4428

16,7440

16,7440

15,2579

15,2579

1,8782

3,7564

Diversos 500,4439

COEFICIENTE DE REDUÇÃO DO II - FIXO (9)

$88,00 \%$

Valor do Imposto de Importação em US\$ Suspenso (Sem Redução)

32,124046

Valor da redução do Imposto de Importação em US\$

28,269160

Valor do Imposto de Importação reduzido em US\$ (a pagar)

3,854886

Em que:

(1) descrição dos componentes que compõem a estrutura de custos do produto;

(2) quantidade de componentes utilizados na fabricação de uma unidade do produto;

(3) valor unitário em US\$ dos componentes nacionais e importados adquiridos e necessários para a fabricação de uma unidade do produto;

(4) valor total em US\$ dos componentes nacionais e importados adquiridos e necessários para a fabricação de uma unidade do produto;

(5) alíquota do imposto de importação de cada componente importado;

(6) valor suspenso em US\$ do imposto de importação de cada componente importado por época da sua entrada;

(7) número dos demais componentes importados necessários para a fabricação de uma unidade do produto;

(8) número dos demais componentes nacionais necessários para a fabricação de uma unidade do produto e

(9) não há necessidade de informação do valor da mão de obra e do cálculo do índice de nacionalização por ser redutor fixo $(88 \%)$. 
Ao analisar o Quadro 9, verifica-se que o fabricante ao produzir uma unidade do televisor de 21' efetuou a importação dos componentes no valor de US\$ 47,8636, com imposto de importação suspenso no valor de US\$ 6,152629. Como a redução desse imposto para o produto desse fabricante não se enquadra como veículo automóvel de passeio e bens do setor de informática, ele tem um redutor fixo de $88 \%$. Logo, o fabricante abate dos impostos suspensos o valor de US\$ $\mathbf{5 , 4 1 4 3 1 4}$ e recolhe, por época da venda para o restante do território nacional, o valor de US\$ $\mathbf{0 , 7 3 8 3 1 5}$

O Quadro 10 mostra que o fabricante, ao produzir uma motocicleta modelo 125 efetuou a importação dos componentes no valor de US\$ 174,6265 com imposto de importação suspenso no valor de US\$ 32,124046. Como a redução desse imposto para o produto desse fabricante não se enquadra como veículo automóvel de passeio e bens do setor de informática, ele tem um redutor fixo de $88 \%$. Logo, o fabricante abate dos impostos suspensos o valor de US\$ $\mathbf{2 8 , 2 6 9 1 6 0}$ e recolhe, por época da venda para o restante do território nacional, o valor de US\$ 3,854886,

O exemplo do Quadro 11 mostra o cálculo de um produto "unidade central de processamento", pertencente ao segmento de informática e, por isso, possui um redutor variável. O cálculo do imposto de importação reduzido, a pagar por época da venda para o restante do território nacional, será calculado de acordo com o índice de nacionalização, ou seja, de acordo com a proporção de componentes nacionais em relação ao seu custo total.

Quadro 11 - Demonstração de cálculo do imposto de importação reduzido de uma unidade digital de processamento de pequeno porte - redutor variável

\begin{tabular}{|c|c|c|c|c|c|}
\hline $\begin{array}{c}\text { Componentes } \\
\text { (1) }\end{array}$ & $\begin{array}{c}\text { Quantidade } \\
\text { (2) }\end{array}$ & $\begin{array}{c}\text { Valor } \\
\text { Unitário } \\
\text { US\$ (3) }\end{array}$ & $\begin{array}{c}\text { Valor Total } \\
\text { US\$ (4) }\end{array}$ & $\begin{array}{c}\text { Alíquota \% } \\
\text { do II (5) }\end{array}$ & $\begin{array}{c}\text { Valor do } \\
\text { II } \\
\text { Suspenso } \\
\text { US\$ (6) } \\
\end{array}$ \\
\hline \multicolumn{6}{|c|}{ A - ESPECIFICAÇÃO DOS COMPONENTES IMPORTADOS } \\
\hline 1. Circuito integrado monolítico & 1 & 155,2400 & 155,2400 & 0,00 & 0,000000 \\
\hline 2. Unidade de disco rígido & 1 & 55,8300 & 55,8300 & 9,50 & 5,303850 \\
\hline 3. Circuito integrado "chipset" & 1 & 14,1400 & 14,1400 & 1,50 & 0,212100 \\
\hline 4. Fonte de alimentação & 1 & 7,8900 & 7,8900 & 10,50 & 0,828450 \\
\hline 5. Gabinete de metal & 1 & 5,8500 & 5,8500 & 19,00 & 1,111500 \\
\hline 6. Circuito integrado SMD Memória & 4 & 3,8270 & 15,3080 & 1,50 & 0,229620 \\
\hline 7. Bateria de lítio & 1 & 2,5400 & 2,5400 & 1,50 & 0,038100 \\
\hline 8. Transistor de dissipação & 19 & 0,0086 & 0,1634 & 11,00 & 0,017974 \\
\hline 9. Outros (7) & 205 & Diversos & 34,4113 & Diversas & 1,554191 \\
\hline TOTAL & 213 & & 291,3727 & & 9,295785 \\
\hline
\end{tabular}


continuação

\begin{tabular}{|c|c|c|c|c|}
\hline \multicolumn{5}{|c|}{ B - ESPECIFICAÇÃO DOS COMPONENTES NACIONAIS } \\
\hline 1. Embalagem & 1 & 1,3700 & 1,3700 & \\
\hline 2. Calço de EPS & 1 & 0,5000 & 0,5000 & \\
\hline 3. Cantoneira divisória & 1 & 0,2300 & 0,2300 & \\
\hline 4. Etiqueta & 1 & 0,0800 & 0,0800 & \\
\hline 5. Manual para placa & 1 & 0,0600 & 0,0600 & \\
\hline 6. Solda sem fio & 1 & 0,0310 & 0,0310 & \\
\hline 7. Solda em barras & 1 & 0,0180 & 0,0180 & \\
\hline 8. Fluxo & 1 & 0,0100 & 0,0100 & \\
\hline 9. Outros (8) & 0 & & 0,0000 & \\
\hline TOTAL & 8 & & 2,2990 & \\
\hline \multicolumn{3}{|c|}{ C - CUSTO DA MÃO DE OBRA EM US\$ (9) } & 35,5200 & \\
\hline \multicolumn{3}{|c|}{ D - CUSTO TOTAL $(A+B+C)$} & 329,1917 & \\
\hline \multicolumn{4}{|c|}{$\begin{array}{l}\text { COEFICIENTE DE REDUÇÃO DO II - VARIÁVEL (9) } \\
((\text { COMPONENTES NACIONAIS + MAO DE OBRA) / COMPONENTES TOTAIS) X } 100 \\
((2,2990+35,5200) /(329,1917)) \times 100\end{array}$} & $11,49 \%$ \\
\hline \multicolumn{4}{|c|}{ Valor do Imposto de Importação em US\$ Suspenso (Sem Redução) } & 9,295785 \\
\hline \multicolumn{4}{|c|}{ Valor da redução do Imposto de Importação em US\$ } & 1,067941 \\
\hline \multicolumn{4}{|c|}{ Valor do Imposto de Importação reduzido em US\$ (a pagar) } & 8,227844 \\
\hline
\end{tabular}

Em que:

(1) descrição dos componentes que compõem a estrutura de custos do produto;

(2) quantidade de componentes utilizados na fabricação de uma unidade do produto;

(3) valor unitário em US\$ dos componentes nacionais e importados adquiridos e necessários para a fabricação de uma unidade do produto;

(4) valor total em US\$ dos componentes nacionais e importados adquiridos e necessários para a fabricação de uma unidade do produto;

(5) alíquota do imposto de importação de cada componente importado;

(6) valor suspenso em US\$ do imposto de importação de cada componente importado por época da sua entrada;

(7) número dos demais componentes importados necessários para a fabricação de uma unidade do produto;

(8) número dos demais componentes nacionais necessários para a fabricação de uma unidade do produto; 
(9) por tratar-se de redutor variável, há a necessidade de informação do valor da mão de obra e do cálculo do índice de nacionalização;

(A) relação dos componentes importados necessários para a fabricação de uma unidade do produto;

(B) relação dos componentes nacionais necessários para a fabricação de uma unidade do produto;

(C) valor da mão de obra direta e encargos sociais necessários para a fabricação de uma unidade do produto e

(D) valor total do custo dos componentes e mão de obra direta e encargos sociais necessários para a fabricação de uma unidade do produto.

Primeiramente, com a aplicação da Equação 01, determina-se o índice de nacionalização e que servirá como coeficiente de redução do imposto de importação.

$$
I N=\frac{2,2990+35,5200}{291,3727+2,2990+35,52}=0,1149
$$

Isso significa dizer que, na composição dos custos de fabricação da unidade digital de processamento de pequeno porte, $11,49 \%$ são componentes nacionais e, por isso, a empresa reduzirá esse mesmo percentual de imposto de importação em cada unidade vendida para o restante do território nacional, efetuando o recolhimento de $88,51 \%$ do imposto de importação suspenso.

Com esses cálculos, verifica-se que para o fabricante produzir uma unidade digital de processamento de pequeno porte, quando ele efetuou a importação dos componentes, foi registrado como imposto de importação suspenso o valor de US\$ 9,295785. Como a redução desse imposto para o produto desse fabricante se enquadra como bens do setor de informática, ele tem um redutor variável, calculado de acordo com o índice de nacionalização, de 11,49\%. Logo, o fabricante abate dos impostos suspensos o valor de US\$ $\mathbf{1 , 0 6 7 9 4 1}$ e recolhe, por época da venda para o restante do território nacional, o valor de US\$ 8,227844. 


\title{
3.2.2 Imposto sobre produtos industrializados
}

Outro grande incentivo fiscal concedido às empresas industriais instaladas na Zona Franca de Manaus é o incidente sobre Imposto sobre Produtos Industrializados (IPI). O incentivo fiscal sobre esse imposto apresenta-se de duas formas: um incidente sobre o IPI nacional, aquele decorrente das compras de produtos industrializados no país e a outro incidente sobre o IPI vinculado, aquele incidente sobre os produtos estrangeiros importados pelas empresas instaladas na Zona Franca de Manaus.

Com relação ao IPI nacional, vale destacar que o Decreto n. 4.543/2002 (RA), estabelece em seu art. 454 que

\begin{abstract}
A remessa de mercadorias de origem nacional para consumo ou industrialização na Zona Franca de Manaus, ou posterior exportação, será, para efeitos fiscais, equivalente a uma exportação brasileira para o exterior.
\end{abstract}

Isso se torna importante porque, ao ser caracterizada a venda como uma exportação, além de não recolher o valor do imposto, o vendedor (contribuinte) mantém, na sua escrita, o crédito do Imposto sobre Produtos Industrializados (IPI), incidente sobre matérias-primas, produtos intermediários, material de embalagem e equipamentos adquiridos para emprego na industrialização de produtos que venham a ser remetidos para a Zona Franca de Manaus.

O art. 69 do Decreto n. 4.544/2002 (RIPI) estabelece que são isentos do Imposto sobre Produtos Industrializados (IPI);

I - os produtos industrializados na Zona Franca de Manaus - ZFM, destinados, ao seu consumo interno, excluídos as armas e munições, fumo, bebidas alcoólicas e automóveis de passageiros; II - os produtos industrializados na ZFM, por estabelecimentos com projetos aprovados pelo Conselho de Administração da Superintendência da Zona Franca de Manaus - SUFRAMA, que não sejam industrializados pelas modalidades de acondicionamento ou reacondicionamento, destinados a comercialização em qualquer outro ponto do Território Nacional,... e

III - os produtos nacionais entrados na ZFM, para seu consumo interno, utilização ou industrialização, ou ainda, para serem remetidos, por intermédio de seus entrepostos, à Amazônia Ocidental, excluídos as armas e munições, perfumes, fumo, automóveis de passageiros e bebidas alcoólicas.

Com relação aos produtos industrializados importados, com a finalidade de isonomia com os produtos industrializados nacionais, na época do seu desembaraço ocorre o fato gerador e, consequentemente, a incidência do IPI vinculado. Na Zona Franca de Manaus, o desembaraço 
desses produtos é realizado com a suspensão de tributos e, de acordo, com a sua destinação permanecem isentas. $\mathrm{O}$ artigo 73 do Decreto n. 4.544/2002 (RIPI) estabelece

Os produtos de procedência estrangeira importados pela ZFM serão desembaraçados com suspensão do imposto, que será convertida em isenção quando os produtos forem ali consumidos ou utilizados na industrialização de outros produtos, na pesca e na agropecuária, na instalação e operação de indústrias e serviços de qualquer natureza, ou estocados para exportação para o exterior, excetuados as armas e munições, fumo, bebidas alcoólicas e automóveis de passageiros.

Por outro lado, os produtos de origem nacional que, exportados para o exterior, venham a ser, posteriormente, importados por meio da Zona Franca de Manaus, não podem ser desembaraçados com suspensão do Imposto sobre Produtos Industrializados (IPI). Ao mesmo tempo, os produtos estrangeiros importados pela ZFM, quando dessa saírem para outros pontos do território nacional, ficam sujeitos ao pagamento do imposto exigível quando da importação.

Como se observa, o processo industrial, desenvolvido na Zona Franca de Manaus, é totalmente desonerado do Imposto sobre Produtos Industrializados, o que, por si só, repercute numa elevada vantagem competitiva em relação a outros Estados da Federação.

\subsubsection{Imposto sobre circulação de mercadorias e serviços}

Antes da vigência da Lei Estadual do Amazonas n. 2.826, de 29 de setembro de 2003, havia uma infinidade de normas vigentes e não alinhadas às diretrizes da livre concorrência. Com a entrada em vigor dessa Lei, o governo do Amazonas passou a dar um tratamento isonômico aos produtos dos mesmos segmentos. Essa Lei disciplina e unifica os incentivos fiscais estaduais relacionados à redução total ou parcial do ICMS. O artigo 13 estabelece que

O incentivo fiscal do crédito estímulo do ICMS será concedido por produto, observado tratamento isonômico para bens classificados na mesma posição e subposição do código tarifário NCM/SH, de acordo com sua caracterização definida no art. 10, [...]

De acordo com o art. 2o da Lei n. 2.826/2003;

Os incentivos fiscais destinados às empresas industriais e agroindustriais constituem-se em crédito estímulo, diferimento, isenção, redução de base de cálculo e crédito fiscal presumido do Imposto sobre Operações Relativas à Circulação de Mercadorias e sobre Prestações de Serviços de Transporte Interestadual e Intermunicipal e de Comunicação - ICMS. 
Dentre as diversas modalidades de incentivos fiscais estaduais, concedidos às empresas industriais instaladas na Zona Franca de Manaus, este trabalho analisa o crédito estímulo, especificamente no que diz respeito à sua concessão, cálculo e contabilização. É de se esperar que, ao analisá-lo, algumas das demais modalidades como é o caso do crédito presumido, da manutenção do crédito fiscal e do diferimento, sejam comparadas e discutidas porque podem interferir em seu cálculo.

Segundo Martins et al. (2008, p. 55), a literatura sobre a concessão de incentivos fiscais relacionados ao ICMS é escassa, uma vez que não existe caso similar no País em que o Estado seja uma área de exceção fiscal, motivo pelo qual todas as análises e interpretações são normativas.

A referida legislação sobre incentivos fiscais do ICMS estabelece que a concessão dos incentivos fiscais caberá, unicamente, aos produtos resultantes de atividades consideradas de fundamental interesse para o desenvolvimento do Estado, cujas empresas satisfaçam, pelo menos, três da seguintes condições:

\footnotetext{
I - concorram para o adensamento da cadeia produtiva, com o objetivo de integrar e consolidar o parque industrial, agroindustrial e de indústrias de base florestal do Estado;

II - contribuam para o incremento do volume de produção industrial, agroindustrial e florestal do Estado;

III - contribuam para o aumento da exportação para os mercados nacional e internacional;

IV - promovam investimento em pesquisa e desenvolvimento de tecnologia de processo e/ou produto;

$\mathrm{V}$ - contribuam para substituir importações nacionais e/ou estrangeiras;

VI - promovam a interiorização de desenvolvimento econômico e social do Estado;

VII - concorram para a utilização racional e sustentável de matéria-prima florestal e de princípios ativos da biodiversidade amazônica, bem como dos respectivos insumos resultantes de sua exploração;

VIII - contribuam para o aumento das produções agropecuária e afins, pesqueira e florestal do Estado;

IX - gerem empregos diretos e/ou indiretos no Estado;

$\mathrm{X}$ - promovam atividades ligadas à indústria do turismo. (Lei AM. 2.826/2003)
}

O nível de incentivo do crédito estímulo corresponde ao produto da aplicação do percentual que a empresa tem do seu produto, que varia de 55\% (cinqüenta e cinco por cento) a $100 \%$ (cem por cento) sobre o saldo devedor do ICMS. Em regra geral, os percentuais de crédito estímulo são os seguintes:

- $\quad 90,25 \%$ (noventa inteiros e vinte e cinco centésimos por cento) para os produtos caracterizados como bens intermediários; produtos de limpeza, café torrado e moído, 
vinagre, bolachas e biscoitos, macarrão e demais massas alimentícias; mídias virgens e gravadas, com cessão de direitos quando aplicáveis, fabricadas conforme processo produtivo básico, previsto em legislação federal, e distribuídas a partir da Zona Franca de Manaus;

- $\quad 75 \%$ (setenta e cinco por cento) para os produtos caracterizados como placas de circuito impresso montadas para a produção de aparelhos de áudio e vídeo; bens de capital; bens de consumo industrializados destinados à alimentação; produtos agroindustriais e afins, florestais e faunísticos, medicamentos, preparações cosméticas e produtos de perfumaria que utilizem, dentre outras, matérias-primas produzidas no interior e/ou oriundas da flora e fauna regionais, pescado industrializado e produtos de indústria de base florestal;

- $55 \%$ (cinqüenta e cinco por cento) para os produtos caracterizados como bens industrializados de consumo não compreendidos nos percentuais anteriores.

Para obter o direito aos incentivos fiscais do ICMS, a empresa interessada requererá os incentivos ao Governo do Estado por intermédio da Secretaria de Estado de Planejamento e Desenvolvimento Econômico - SEPLAN, devendo seu pleito estar fundamentado em projeto técnico-econômico que demonstre a viabilidade do empreendimento e sua adequação a essa Lei, na forma e condições estabelecidas em regulamento, conforme disposto no art. 5- da Lei AM n. 2.826/2003, regulamentado pelo Decreto n. 23.994, de 29.12.2003. Segundo essa mesma Lei, em seu artigo 19, as empresas beneficiadas com incentivos fiscais deverão cumprir as seguintes exigências:

I - implantar o projeto técnico e de viabilidade econômica na forma aprovada pelo CODAM, no prazo máximo de 24 (vinte e quatro) meses, a contar da data da publicação do Ato Concessivo, prorrogável desde que devidamente justificado com novo cronograma;

II - manter programas de benefícios sociais para os seus empregados, de acordo com o enunciado nos arts. 8- e 212, § 1ำ da Constituição Estadual, especialmente, nas áreas de alimentação, saúde, lazer, educação, transporte e creche a preços subsidiados;

III - desenvolver programas de regionalização e de desenvolvimento tecnológico, nos termos e condições estabelecidas pela legislação;

IV - manter programas de gestão de qualidade, meio ambiente e de segurança e saúde ocupacional; V - manter em seus estabelecimentos, em local visível ao público, placa alusiva aos incentivos previstos nesta Lei, de acordo com modelo e especificações aprovados pela SEPLAN;

VI - reservar parcela de sua produção de bens de consumo final para atender a demanda local, hipótese em que a empresa industrial incentivada deverá aplicar, na saída interna do produto, a alíquota do ICMS reduzida para 7\% (sete por cento);

VII - assegurar, em condições semelhantes de competitividade, quanto a preços, nestes incluídos os custos totais de logísticas, qualidade e prazo de entrega, preferência à aquisição de produtos intermediários, partes e peças, produtos secundários e materiais de embalagens, fabricados em território amazonense, preferencialmente no interior do Estado;

VIII - utilizar, em condições semelhantes de competitividade, infra-estrutura local de serviços, tais como: publicidade, consultoria, construção civil, contabilidade, gráficos, segurança, fechamento de contrato de câmbio, aquisição de passagens aéreas e locação de veículos; 
IX - manter a administração no Estado, inclusive um diretor-residente;

X - recolher o Fundo de Garantia por Tempo de Serviço - FGTS e contribuições sociais e previdenciárias no Estado do Amazonas;

$\mathrm{XI}$ - manter menores e deficientes físicos em seu quadro funcional, salvo se a empresa incentivada desenvolver atividades penosas, perigosas ou insalubres, observada a legislação federal pertinente; XII - recolher os ICMS apurados, relativos à saída do produto incentivado, no prazo regulamentar; XIII - recolher contribuição financeira, em caráter irretratável e irrevogável, durante todo o período de fruição dos incentivos, observadas as formas e condições estabelecidas em regulamento:

a) ao Fundo de Fomento às Micro e Pequenas Empresas - FMPES, no valor correspondente a 6\% (seis por cento) do crédito estímulo, calculado em cada período de apuração do ICMS;

b) em favor da Universidade do Estado do Amazonas - UEA, no valor correspondente a:

1 - 10\% (dez por cento) do crédito estímulo, calculado em cada período de apuração do ICMS, quando se tratar empresa industrial beneficiada com nível de $100 \%$ (cem por cento) de crédito estímulo;

$2-1,3 \%$ (um inteiro e três décimos por cento) sobre o faturamento bruto, sujeito a diferimento, quando se tratar das operações previstas no art. 14, II;

$3-1,5 \%$ (um e meio por cento) do crédito estímulo, calculado em cada período de apuração do ICMS, nos demais casos.

c) ao Fundo de Fomento ao Turismo, Infra-estrutura, Serviços e Interiorização do Desenvolvimento do Amazonas - FTI, no valor correspondente a:

$1-2 \%$ (dois por cento) sobre o valor FOB das importações do exterior de matérias-primas, bens intermediários, materiais secundários e de embalagem e outros insumos empregados na fabricação de bens finais, consoante projeto de viabilidade econômica aprovado pela CODAM, exceto na hipótese dos bens previstos no artigo 13, § 13, II, III e IV;

2 - $1 \%$ (um por cento) sobre o faturamento bruto das empresas industriais beneficiadas com nível de $100 \%$ (cem por cento) de crédito estímulo;

3 - $1 \%$ (um por cento) sobre o faturamento bruto relativo aos bens intermediários com diferimento de que trata o inciso II do art. 14;

$4-1 \%$ (um por cento) sobre o valor das matérias-primas, bens intermediários, materiais secundários e de embalagem procedentes de outras unidades da Federação e adquiridos pelas indústrias produtoras de bens finais incentivados.

A enumeração de todas as exigências legais para a obtenção dos incentivos fiscais do ICMS pelas empresas industriais estabelecidas na Zona Franca de Manaus faz-se necessária para destacar que, em nenhuma das exigências, aparece a obrigatoriedade de aplicação, controle e acompanhamento do valor do incentivo fiscal no investimento, o que contribui para desmistificar a ideia de subvenção para investimento lançada como reserva de capital no patrimônio líquido das empresas.

Os artigos 40 e 92 dos Atos das Disposições Constitucionais Transitórias, da Constituição Federal de 1988, estabelecem que o Estado do Amazonas pode conceder crédito do imposto de circulação de mercadorias nas operações comerciais dentro da Zona Franca, igual ao montante que teria sido pago na origem em outros Estados da União, por considerar a remessa de mercadorias para a Zona Franca equivalente a uma exportação.

Esse benefício fiscal de crédito presumido foi concedido a fim de evitar que o benefício da remessa de produtos industrializados de origem nacional destinados à comercialização ou 
industrialização na ZFM viesse a ser caracterizado como forma de transferência de receita de um outro Estado para o Amazonas, já que o valor da operação incentivada, mediante a não exigibilidade do ICMS na origem seria tributada na operação subsequente. (MARTINS et al., 2008, p. 71).

A autorização para o Estado do Amazonas conceder esse crédito presumido, também, está prevista no Convênio ICM 65/88. Nesse mesmo convênio, foi autorizada a manutenção do crédito fiscal por parte do estabelecimento industrial remetente de produtos industrializados destinados à comercialização ou industrialização na ZFM nos seguintes termos:

Fica assegurada ao estabelecimento industrial que promover a saída mencionada na cláusula primeira, a manutenção dos créditos relativos às matérias primas, materiais secundários e materiais de embalagens utilizados na produção dos bens objeto daquela isenção. (CONVÊNIO ICM 65/88, Cláusula Terceira).

A manutenção do crédito presumido do ICMS previsto no Convênio ICM 65/88 caracteriza-se como incentivo fiscal concedido pelo modelo industrial Zona Franca de Manaus, mas com destinação aos estabelecimentos industriais localizados em outros Estados da Federação. Ao mesmo tempo, ele, também, prevê benefício em favor do contribuinte localizado no Município de Manaus ao determinar que o estabelecimento que realizar a operação de remessa de produtos industrializados de origem nacional para comercialização ou industrialização na ZFM deve abater do preço da mercadoria o valor equivalente ao ICMS que seria devido se não houvesse o tratamento de equiparação da referida remessa à exportação. O convênio, assim, estabelece:

Ficam isentas do imposto as saídas de produtos industrializados de origem nacional para comercialização ou industrialização na Zona Franca de Manaus, desde que o estabelecimento destinatário tenha domicílio no Município de Manaus.

[...]

Para efeito de fruição do benefício previsto nesta cláusula, o estabelecimento remetente deverá abater do preço da mercadoria o valor equivalente ao imposto que seria devido se não houvesse a isenção indicado expressamente na nota fiscal.

$\mathrm{Na}$ Tabela 16, a seguir, é mostrado um exemplo numérico do crédito estímulo e as contribuições exigidas pela Lei AM n. 2.826/2003. 
Tabela 16 - Demonstração do cálculo de crédito estímulo e ICMS a pagar

\begin{tabular}{|c|c|c|c|c|}
\hline \multirow{2}{*}{ Item } & \multirow{2}{*}{ Operação } & \multicolumn{3}{|c|}{ Valor em RS / de Crédito Estímulo } \\
\hline & & $90,25 \%$ & $75 \%$ & $55 \%$ \\
\hline 1. & Valor de saída da mercadoria produzida na ZFM & 500,00 & 500,00 & 500,00 \\
\hline 2. & ICMS sobre vendas (Alíquota interestadual - 12\%) & 60,00 & 60,00 & 60,00 \\
\hline 3. & Créditos Fiscais ICMS Entrada Produtos Importados & 21,25 & 21,25 & 21,25 \\
\hline 4. & Créditos Fiscais ICMS Entrada - Crédito presumido (7\%) & 9,41 & 9,41 & 9,41 \\
\hline 5. & Saldo Devedor do ICMS (2 - 3 - 4) & 29,34 & 29,34 & 29,34 \\
\hline 6. & Crédito Estímulo & 26,48 & 22,00 & 16,14 \\
\hline 7. & Total ICMS a Pagar (5 - 6) & 2,86 & 7,34 & 13,20 \\
\hline 8. & $\begin{array}{l}\text { Contribuição ao Fundo de Fomento às Micro e Pequenas } \\
\text { Empresas - FMPES ( } 6 \% \text { do crédito estímulo) }\end{array}$ & 1,59 & 1,32 & 0,97 \\
\hline 9. & Contribuição para UEA (1,5\% do crédito estímulo) & 0,40 & 0,33 & 0,24 \\
\hline 10. & $\begin{array}{l}\text { Contribuição ao Fundo de Fomento ao Turismo, } \\
\text { Infraestrutura, Serviços e Interiorização do Desenvolvimento } \\
\text { do Amazonas - FTI (1,5\% sobre o custo das matérias primas) }\end{array}$ & 3,12 & 3,12 & 3,12 \\
\hline
\end{tabular}

Obs. Item 3 - considerado 17\% sobre R\$ 125,00 de insumos importados; Item 4 - considerado o valor dos insumos em R \$ 134,41, menos 7\% de desconto do crédito presumido (R 9,41 ), perfazendo o valor de NF de R\$ 125,00; Item 10 - calculado como 2\% sobre o valor FOB da importação (R\$ 93,75) e 1\% sobre as compras nacionais $(\mathrm{R} \$ 125,00)$.

\subsubsection{As contribuições para o PIS e a COFINS}

Como as vendas de mercadorias para estabelecimentos localizados na Zona Franca de Manaus são equivalentes a uma exportação de produto brasileiro para países estrangeiros, as empresas que realizam vendas para aquela região devem considerar essas vendas isentas do pagamento das contribuições para o Programa de Integração social (PIS) e à Contribuição para o Financiamento da Seguridade Social (COFINS).

Conforme estabelecido pelo Decreto-lei n. 288/67, a Zona Franca de Manaus é uma área de livre comércio de importação e exportação e de incentivos fiscais especiais e as vendas realizadas para essa região devem receber o mesmo tratamento, gozar dos mesmos incentivos, concedidos às exportações. O artigo 80 do ADCT manteve a Zona Franca de Manaus com suas características pelo prazo de 25 anos e não permite que outra lei, a não ser federal, que modifique os critérios de aprovação de seus projetos.

A Lei n. 9.044/95, ao tratar da determinação da base de cálculo da contribuição ao PIS, dispôs no sentido de que, embora as vendas ao exterior pudessem ser excluídas da Receita Bruta, as vendas à Zona Franca de Manaus não seriam assim consideradas. O Decreto n. 1.030/93 dispensou tratamento igual com relação à COFINS. Essas revogações foram mantidas pela 
MP n. 1.858-6 e MP n. 2.037-25. Por meio de liminar na ADIN n. 2.348-9, de 07 de dezembro de 2000, foi suspensa a eficácia desses dispositivos revogatórios.

A MP n. 2.037-25 foi editada com a supressão da expressão "Zona Franca de Manaus" do dispositivo que revogava a isenção, mantendo-se a vedação para a Amazônia Ocidental e as demais áreas de livre comércio. A MP n. 2158/01 permaneceu com o mesmo entendimento.

Posteriormente, a EC n. 33/2001, introduziu o art. 149 na Constituição Federal, tornando as exportações imunes a todas as contribuições sociais. Com a Solução de Consulta COSIT n. 6 e as Soluções de Divergências n. 7, 8 e 9, de 2002, a RFB adotou o entendimento de que a isenção somente poderia ser aplicada a partir de 18.12.2000 e sobre determinadas receitas, ficando de fora as receitas das vendas à ZFM.

Em 13.12.02, por meio de liminar na Reclamação n. 2.216-1, foi determinada a suspensão dos efeitos das Soluções de Consulta e de Divergências. A RFB emitiu Ato Declaratório COSIT n. 42/2002, suspendendo tais efeitos, entretanto, o Ato Declaratório COSIT n. 12/2007, restabeleceu os efeitos das Soluções, em virtude da decisão do STF que revogou a liminar concedida na Reclamação n. 2.216-1, por perda do objeto da ADIN n. 2.348-9.

Como se observa, os diversos questionamentos administrativos e judiciais sobre a incidência dessas contribuições sobre as receitas de vendas às empresas instaladas na Zona Franca de Manaus, e ações de inconstitucionalidade ao Supremo Tribunal Federal, com muitas questões ainda pendentes, as empresas não vêm usufruindo desses benefícios físcais. Logo, essas contribuições não se caracterizam como tais, o que, para este trabalho, deixa de ser dada demasiada importância.

O estudo e conhecimento das variáveis que contribuem para esse preço mais baixo, decorrente da fabricação de um produto feito numa Zona de Livre Comércio, para uma zona doméstica, proporcionado, basicamente, pelos incentivos fiscais concedidos, torna-se relevante. Além do mais, o conhecimento técnico sobre essas variáveis será de fundamental importância para a discussão, a análise, a quantificação e a avaliação de quais são os efeitos dos incentivos fiscais na criação e distribuição de riqueza pela Zona Franca de Manaus, objetivo geral deste trabalho. 


\subsection{A formação de preço e as variáveis de custos}

Retornando à reportagem da edição de 03 de setembro de 2003, da Revista Veja, na qual afirmava que "um televisor produzido na Zona Franca chega às lojas de São Paulo custando para o fabricante $18 \%$ menos do que outro, idêntico, feito fora de Manaus", a fim de entender essa diferença, torna-se imprescindível conhecer as variáveis que formam o custo desse televisor e que propicia tal vantagem comparativa.

Horngren et al. (2000, p. 302) mostra que "A teoria econômica e pesquisas de como os executivos tomam decisões sobre preços revelam que as companhias ponderam diferentemente clientes, concorrentes e custos. As que vendem produtos tipo commodity em mercados altamente competitivos têm que aceitar o preço imposto pelas forças de mercado." Logo, a informação precisa sobre o custo do produto é essencial para que o administrador possua conhecimentos suficientes para a determinação do preço de seu produto.

Ele acrescenta que os objetivos da alocação de custos são:

\footnotetext{
1. Fornecer informação para decisões econômicas;

2. Motivar administradores e empregados;

3. Justificar custos ou calcular reembolsos;

4. Mensurar o lucro e os ativos para atendimento das exigências legais dos relatórios destinados ao público externo. (Ibid., p. 330).
}

Hansen e Mowen (2003 p. 131) acrescentam que "O custo unitário é uma informação crucial para um fabricante. Os custos unitários são essenciais para avaliar o estoque, determinar o resultado e tomar um número de decisões importantes.” Mas, se a informação sobre o custo unitário deve ou não incluir todos os custos de manufatura, depende do propósito para o qual a informação está sendo usada e como o administrador deseja visualizar seu custo para fins gerenciais, societários ou tributários.

$\mathrm{Na}$ sua visão, os custos variáveis são definidos como custos que, no total, variam em proporção direta às mudanças em um direcionador de atividade e que, para alguns sistemas de custos, a mão de obra, quando paga em salários fixos, é considerada como custo fixo, a exemplo do que ocorre no Brasil, com a exigência da CLT de 220 horas mínimas por mês. (Ibid., p. 668). 
Como o resultado operacional inclui, apenas, receitas e despesas das operações normais da empresa, um refinamento dessa abordagem é o conceito de margem de contribuição. Esse conceito é definido por Hansen e Mowen (2003, p. 594) como "receita de vendas menos o total de custo variável" e por Atkinson et al. (2000, p. 193), numa abordagem unitária, como a "A diferença (P-V) entre o preço e o custo variável por unidade é definida como margem de contribuição unitária."

Shin (2000, p. 154) constrói o conceito de margem de contribuição da seguinte forma:

1. A margem de contribuição (MC) é o excesso das vendas (V) sobre os custos variáveis (CV) de um produto ou serviço. É o valor disponível para cobrir os custos fixos e gerar lucros. Logo,

- $M C=V-C V$

2. Margem de Contribuição Unitária $(\mathrm{MCu})$. A margem de contribuição unitária é o preço de venda unitário (p) sobre o custo variável unitário (v). Logo,

- $\quad M C u=p-v$

Com a definição dos custos variáveis estimados, acrescidos da parcela de custos fixos e do montante de lucro desejado, aplica-se o markup para a obtenção do preço de oferta do produto. Hansen (2003, p. 113) afirma que "O julgamento gerencial é criticamente importante na determinação do comportamento de custos e é, de longe, o método mais amplamente utilizado na prática." Ele acrescenta que essa prática tem sido utilizada nos sistemas de contabilidade de custos mais avançados e levanta a hipótese de que a vantagem de se usar o julgamento gerencial para separar custos fixos e variáveis é a sua simplicidade e que, em situações em que o gestor tem um profundo conhecimento da empresa e de seus padrões de custos, esse método pode gerar bons resultados.

Neste trabalho, são desenvolvidas as diversas equações que demonstram a composição das variáveis de custos que impactam no preço do produto e que, ao término, busca mostrar a composição de todos esses custos para um produto fabricado na Zona Franca de Manaus e o mesmo produto fabricado fora daquela região, sem incentivos fiscais. 
As definições utilizadas são as seguintes:

- O custo total do produto, aqui sem considerar o custo da mão de obra por considerá-la fixa e com o intuito de trabalhar com o conceito de margem de contribuição. Logo,

$$
C T=C C N+C C I
$$

em que:

$C T=$ Custo Total;

$C C N=$ Custo dos Componentes Nacionais e

$C C I=$ Custo dos Componentes Importados.

- O Custo dos Componentes Nacionais $(C C N)$ é obtido pelo preço das mercadorias mais o frete de entrega, menos o ICMS. Logo, obtém-se:

$$
C C N=N F C-(I C M S) \text {, }
$$

sendo,

$$
I C M S=N F C x T 1
$$

em que:

$N F C=$ Nota Fiscal de Compra e

$T 1$ = Alíquota do ICMS incidente sobre a compra de produtos nacionais.

- O Custo dos Componentes Importados (CCI) é obtido pela soma do valor aduaneiro (VA) mais o imposto de importação (II). Entretanto, para os efeitos de visualização dos tributos incidentes na importação, torna-se imprescindível o conhecimento dos cálculos dos seguintes tributos: i) imposto sobre produtos industrializados (IPI); ii) imposto sobre circulação de mercadorias (ICMS) e iii) contribuições para o PIS e a COFINS. Esses tributos não são acrescentados ao custo dos componentes importados por considerá-los no princípio da não cumulatividade e, consequentemente, recuperados.

Daí obtém-se:

$$
C C I=V A+(V A x i I I),
$$

e

$$
V A=V C E+F I+S I,
$$

em que:

$V C E=$ Valor da compra no exterior;

$F I=$ Frete Internacional e

$S I=$ Seguro Internacional. 
- O valor do IPI vinculado à importação é encontrado pela equação:

$$
I P I=(V A+(V A \times i I I)) \times i I P I,
$$

em que:

$i I P I=$ alíquota do IPI.

- $\quad$ O valor do ICMS devido na importação dos produtos é calculado pela seguinte equação:

$$
I C M S=\{(V A+I I+I P I) /(1-i I C M S)\} \times i I C M S,
$$

em que:

iICMS = alíquota do ICMS.

- Os valores das contribuições PIS e COFINS na importação são calculados pela seguinte equação:

$$
\begin{aligned}
& B C p c=(V A+I C M S) /[1-(i P I S+i C O F)], \text { logo, } \\
& P I S \text { na Importação }=B C p c \times \text { iPIS e } \\
& \text { COFINS na Importação }=B C p c \times i C O F,
\end{aligned}
$$

em que:

$B C p c=$ Base de cálculo PIS e COFINS na importação;

$i P I S=$ alíquota do PIS na importação e

$i C O F=$ alíquota da COFINS na importação.

A Tabela 17, a seguir, demonstra um exemplo ilustrativo das variáveis de custos que impactam no preço de venda de um produto fabricado na Zona Franca de Manaus e o mesmo produto fabricado em outra região sem os incentivos fiscais.

Para fins didáticos, foi estipulado um preço de venda, condizente com a afirmação da reportagem da Revista Veja, com um percentual de diferença de preço de $20 \%$ sobre o preço do produto fabricado fora da ZFM, ao invés de $18 \%$. 
Tabela 17 - Demonstração das variáveis de custos que impactam no preço

\begin{tabular}{|c|c|c|c|}
\hline \multirow[b]{2}{*}{ Itens } & $\begin{array}{c}\text { Produto } \\
\text { Fora ZFM } \\
\end{array}$ & $\begin{array}{c}\text { Produto } \\
\text { ZFM }\end{array}$ & Diferença \\
\hline & Valores - R\$ & Valores - R\$ & Valores - R\$ \\
\hline 1. Preço de Venda & $\mathbf{5 0 0 , 0 0}$ & 400,00 & $(\mathbf{1 0 0 , 0 0 )}$ \\
\hline \multicolumn{4}{|l|}{ 2. Custos Componentes Nacionais } \\
\hline 2.1. Custo dos componentes nacionais & 80,00 & 74,40 & $(5,60)$ \\
\hline 2.2. Frete sobre componentes nacionais & 1,60 & 3,20 & 1,60 \\
\hline 2.3. ICMS sobre componentes nacionais & 14,40 & $5,60 *$ & - \\
\hline 2.4. IPI sobre componentes nacionais $(10 \%)$ & 8,00 & - & - \\
\hline Total Gasto com componentes nacionais & 89,60 & $\mathbf{7 7 , 6 0}$ & $(12,00)$ \\
\hline \multicolumn{4}{|l|}{ 3. Custos Componentes Importados } \\
\hline 3.1. Custo dos componentes importados (FOB) & 120,00 & 120,00 & - \\
\hline 3.2. Frete sobre componentes importados & 7,20 & 10,80 & 3,60 \\
\hline 3.3. Seguro sobre componentes importados & 1,00 & 1,00 & - \\
\hline Custo CIF & 128,20 & 131,80 & 3,60 \\
\hline 3.4. Despesas Armazenagem, Alfandegárias e Aduaneiras & 3,20 & 3,30 & 0,10 \\
\hline 3.5. Imposto de Importação (15\%) & 19,23 & 19,77 & - \\
\hline 3.5.1. Imposto de Importação efetivo & 19,23 & 2,37 & $(\mathbf{1 6 , 8 6 )}$ \\
\hline 3.6. IPI $(10 \%)$ & 14,74 & 15,16 & \\
\hline 3.6.1. IPI efetivo pago & 14,74 & - & $(14,74)$ \\
\hline 3.7. ICMS Importação & 36,30 & 34,82 & $(1,48)$ \\
\hline 3.8. Pis na Importação $(1,65 \%)$ & 3,00 & $3,03 * *$ & $(3,00)$ \\
\hline 3.9. Cofins na Importação $(7,6 \%)$ & 13,78 & $13,95 * *$ & $(13,78)$ \\
\hline Total Gasto com componentes importados & 218,45 & 172,29 & $(46,16)$ \\
\hline \multicolumn{4}{|l|}{ 4. Outros Custos/Despesas } \\
\hline 4.1. ICMS sobre a Venda & 90,00 & 68,00 & $(22,00)$ \\
\hline 4.1.1. ICMS efetivo sobre Vendas & 90,00 & 47,23 & $(42,77)$ \\
\hline 4.1.2. ICMS sobre compras & 50,99 & 34,82 & 16,17 \\
\hline 4.1.3. ICMS a recolher & 39,01 & 27,58 & 11,43 \\
\hline 4.1.4. Crédito Estímulo (55\%) & - & 15,17 & \\
\hline 4.1.5. ICMS recolhido & 39,01 & 12,41 & $(26,60) * * *$ \\
\hline 4.2. Frete sobre vendas & 4,00 & 8,00 & 4,00 \\
\hline 4.3. Contribuição para UEA ( $1,5 \%$ sobre o crédito estímulo) & - & 0,23 & $\mathbf{0 , 2 3}$ \\
\hline 4.4. Contribuição para o FMPES (6\% sobre o crédito estímulo) & - & 0,91 & 0,91 \\
\hline 4.5. Contribuição para o FTI **** & & 3,14 & 3,14 \\
\hline 4.6. Comissão sobre Vendas (2\% sobre o preço de venda) & 10,00 & 8,00 & $(2,00)$ \\
\hline 4.7. PIS incidente na venda $(1,65 \%)$ & 8,25 & 6,60 & - \\
\hline 4.7.1. PIS recolhido & 5,25 & 6,60 & 1,35 \\
\hline 4.8. COFINS incidente na venda $(7,6 \%)$ & 38,00 & 30,40 & - \\
\hline 4.8.1. COFINS recolhido & 24,22 & 30,40 & 6,18 \\
\hline 4.9. Contribuição Social $(1,44 \%)$ & 7,20 & 5,76 & $(1,44)$ \\
\hline 4.10. IPI recolhido na venda & 27,26 & - & $(28,26)$ \\
\hline Total de Outros Custos/Despesas & 116,94 & $\mathbf{7 5 , 4 5}$ & $(41,49)$ \\
\hline Margem de Contribuição (R\$) & 75,01 & 74,66 & $(\mathbf{0 , 3 5})$ \\
\hline Margem de contribuição \% & $15,0 \%$ & $18,7 \%$ & - \\
\hline
\end{tabular}

Obs.: * Crédito presumido de 7\%; ** Suspensos; *** Calculado pelo ICMS sobre a venda, deduzido do ICMS na importação, do crédito presumido da compra dos produtos nacionais e do crédito estímulo: $\mathrm{R} \$ 68,00-\mathrm{R} \$$ 34,82 - R\$ 5,60 - (R\$ 27,58 x 0,55); **** Calculado à base de $2 \%$ sobre o valor FOB das importações e $1 \%$ sobre as compras nacionais: $(\mathrm{R} \$ 120,00 \times 2 \%+\mathrm{R} \$ 74,40 \times 1 \%)$. 
Observe-se que, mesmo, com um preço $20 \%$ inferior, o mesmo produto fabricado com os incentivos da ZFM e sem incentivos, fabricado em outra região, fornece uma margem de contribuição praticamente igual em termos absolutos (R\$ 75,01 e R\$ 74,66). Quando comparados em termos percentuais, observe-se que a margem de contribuição do produto fabricado com incentivos na ZFM é maior, representando $18,7 \%$ do preço contra $15,0 \%$ de um produto fabricado sem incentivos fora da ZFM. Esses valores seriam suficientes para a remuneração da mão de obra empregada, para os custos fixos e para a remuneração dos fornecedores de capitais.

Vale destacar que, numa situação com estrutura de custos, de capital e de mercado semelhantes, a diferença $20 \%$ entre os preços praticados (R\$ 500,00 para produtos fabricados fora da ZFM e R\$ 400,00 para produtos fabricados com incentivos na ZFM) seriam suficientes para a tomada de decisão de fabricação do produto naquela zona incentivada.

Sem considerar as alterações nas variáveis, decorrentes de alteração de preços, note-se que numa igualdade de estruturas e preços, o produto fabricado na Zona Franca de Manaus apresenta o valor de $\mathbf{R} \$ \mathbf{1 7 4 , 6 6}(\mathrm{R} \$ 100,00+\mathrm{R} \$ 74,66)$ para cobrir os seus custos fixos e seu montante de lucro, contra $\mathbf{R} \mathbf{\$ 7 5 , 0 1}$ do mesmo produto fabricado em outra região do país.

Partindo-se de um preço base de $\mathrm{R} \$ 500,00$, bastaria uma redução de $\mathrm{R} \$ 80,00$ (18\%) no preço do produto fabricado na ZFM, ao invés de R\$ 100,00, para apresentar vantagens competitivas.

\subsection{A contabilização dos incentivos fiscais}

Ao analisar a legislação tributária brasileira, verifica-se que os incentivos fiscais destinados ao investimento das empresas podem ser contabilizados como subvenções de investimentos, na conta de Reservas de Capital dentro do Patrimônio Líquido.

Martins et al.(2007), no "Manual de Contabilidade das Sociedades por Ações", afirmam que: "Há diversos casos de subvenções, e são mais comuns aqueles concedidos às empresas pelo governo (federal, estadual ou municipal) como incentivo ou ajuda a setores econômicos ou regiões em cujo desenvolvimento haja interesse especial." Lembram que, no caso de 
subvenções para atender a despesas de custeio (cobertura de prejuízos, déficits), seu registro deve ser como receita de exercício. Então, tal receita deve ser registrada separada e destacadamente do resultado das operações normais.

Os dados coletados para esta pesquisa foram os relativos ao período de 2003 a 2007, na vigência da Resolução CFC n. 1.026, de 15 de abril de 2005, que aprova a NBC T 19.4. Seu artigo 3- estipula:

Enquanto a Lei dispuser de forma diferente da NBC T 19.4, os incentivos fiscais e subvenções para investimento podem ser registrados no patrimônio líquido como reserva de capital e devem ser divulgados em notas explicativas os efeitos no Resultado, desde que:

a) o subvencionador tenha a intenção em destinar os incentivos fiscais e subvenções para investimentos; e

b) o subvencionado tenha a obrigação de aplicar tais recursos em investimentos relacionados à implantação, modernização ou expansão de empreendimentos econômicos específicos.

O Pronunciamento Técnico 07, aprovado em 03 de outubro de 2008, sobre Subvenção e Assistências Governamentais, adotado pelo Conselho Federal de Contabilidade por meio da Resolução CFC n. 1.143, de 21 de novembro de 2008, revogou a Resolução CFC n. 1.026, de 15 de abril de 2005, trazendo os seguintes conceitos:

Subvenção governamental é uma assistência governamental geralmente na forma de contribuição de natureza pecuniária, mas não só restrita a ela, concedida a uma entidade normalmente em troca do cumprimento passado ou futuro de certas condições relacionadas às atividades operacionais da entidade. Não são subvenções governamentais aquelas que não podem ser razoavelmente quantificadas em dinheiro e as transações com o governo que não podem ser distinguidas das transações comerciais normais da entidade.

Isenção tributária é a dispensa legal do pagamento de tributo sob quaisquer formas jurídicas (isenção, imunidade, etc.). Redução, por sua vez, exclui somente parte do passivo tributário, restando, ainda, parcela de imposto a pagar. A redução ou a isenção pode se processar, eventualmente, por meio de devolução do imposto recolhido mediante determinadas condições.

Para o reconhecimento da subvenção governamental, inclusive subvenção não monetária a valor justo, o Pronunciamento Técnico CPC 07 recomenda que não deve ser reconhecida até que exista segurança de que a entidade cumprirá todas as condições estabelecidas e de que a subvenção será recebida. Complementa que o seu simples recebimento não é prova conclusiva de que as condições a ela vinculadas tenham sido ou serão cumpridas e que a forma do seu recebimento não influencia no método de contabilização a ser adotado. 
Sobre a contabilização da subvenção governamental, o Comitê de Pronunciamentos Contábeis (CPC) orienta que deve ser reconhecida como receita ao longo do período e confrontada com as despesas que pretende compensar e que não pode ser creditada diretamente no patrimônio líquido. Um dos argumentos para tal procedimento é o fato de que, assim como os tributos são lançados no resultado, é lógico registrar a subvenção governamental, que é, em essência, uma extensão da política fiscal, na demonstração do resultado.

O Pronunciamento Técnico 07 do CPC recomenda que a subvenção, seja por acréscimo de rendimento proporcionado ao empreendimento ou por meio de redução de tributos ou outras despesas, deve ser registrada na demonstração do resultado no grupo de contas de acordo com a sua natureza.

As formas de devolução, isenção ou redução de impostos devidos pelas empresas são as formas mais comuns que se caracterizam como subvenções para investimentos para as empresas privadas e essas não devem ser computadas na base de cálculo do Imposto de Renda, desde que registrada como reserva de capital, conforme disposto no art. 443, inciso I, do Decreto n. 3.000/1999 (RIR). A disposição legal do art. 443 é a seguinte:

\footnotetext{
Não serão computadas na determinação do lucro real as subvenções para investimento, inclusive mediante isenção ou redução de impostos concedidas como estímulo à implantação ou expansão de empreendimentos econômicos, e as doações, feitas pelo Poder Público, desde que (Decreto-Lei n. 1.598, de 1977, art. 38, § 2º, e Decreto-Lei n. 1.730, de 1979, art. 1º, inciso VIII):

I - registradas como reserva de capital que somente poderá ser utilizada para absorver prejuízos ou ser incorporada ao capital social, observado o disposto no art. 545 e seus parágrafos; ou

II - feitas em cumprimento de obrigação de garantir a exatidão do balanço do contribuinte e utilizadas para absorver superveniências passivas ou insuficiências ativas.
}

Complementa a orientação de que se tratando de subvenções destinadas a investimentos (expansão empresarial), são creditadas diretamente nessa conta de Reserva de Capital Doações e Subvenções para Investimentos - para a qual a empresa deve ter subcontas por natureza de subvenção recebida. Dentre os exemplos citados, inclui-se o incentivo de ICMS: para determinados empreendimentos, devido à sua localização ou ramo de atividade, a critério da respectiva Legislação Estadual, que poderão ser concedidos, como incentivo fiscal, reduções do ICMS devido ou devolução do ICMS recolhido. 
Ressalte-se o fato de que tal incentivo é uma subvenção e os recursos correspondentes devem ser, obrigatoriamente, aplicados na expansão da empresa (investimentos). Fica clara a obrigatoriedade de acompanhamento e comprovação da aplicação do valor concedido como incentivo fiscal como investimento não só pela condição caracterizada em Resolução do CFC como também pela forma de tratamento dispensada pela Legislação Tributária.

Esses valores devem ser segregados e contabilizados em contas específicas para o controle, acompanhamento e comprovação. Devido a sua sistemática, ou seja, depósito em conta vinculada até que seja apresentado e aprovado pelo órgão competente um projeto específico de investimento e, ainda mais, à obrigatoriedade de registro de uma reserva de capital na liberação, muitas dúvidas têm surgido quanto a sua forma de contabilização.

Em decorrência das normas da Lei n. 6.404/76 e da legislação fiscal, impondo o registro desse valor em conta de reserva de capital, conforme quadro 12 , o esquema de lançamento a seguir visualizado pode ser apresentado.

Quadro 12 - Esquema de contabilização dos incentivos fiscais do ICMS em conta vinculada

\begin{tabular}{|l|c|c|}
\hline \multicolumn{1}{|l|}{ Quadro 12 - Ébquema de contabilização dos incentivos fiscais do ICMS em conta vinculada } & Crédito \\
\hline No mês de competência & & \\
\hline ICMS faturado nas Vendas & 100 & \\
\hline a ICMS a recolher & & 100 \\
\hline No recolhimento do ICMS & & \\
\hline a) pelos 100\% do imposto & & \\
\hline ICMS a recolher & 100 & \\
\hline a Caixa ou Bancos & & \\
\hline b) pelo valor do incentivo & & \\
\hline Depósitos Vinculados a liberar & & \\
\hline a Reservas de Capital - Subvenções para Investimento & & \\
\hline
\end{tabular}

A Lei n. 11.638/2007, em seu artigo 195-A, dispõe que as Reservas de Incentivos Fiscais constituídas a partir de 1ำ de janeiro de 2008 são reservas de lucros e serão constituídas pela destinação da parcela de lucro líquido do exercício relativo às doações e subvenções governamentais para investimentos. Logo, sob o aspecto contábil, essas doações e subvenções 
para investimentos deverão ser registradas pelas companhias como receitas não operacionais, podendo, inclusive, ser distribuídas como dividendos.

\begin{tabular}{|l|c|c|}
\hline \multicolumn{2}{|c|}{ Quadro 13 - Esquema de contabilização dos incentivos fiscais do ICMS } \\
\hline No mês de competência & Débito & Crédito \\
\hline ICMS faturado nas Vendas & & \\
\hline a ICMS a recolher & 100 & \\
\hline No recolhimento do ICMS & & 100 \\
\hline a) pela parcela a ser recolhida do imposto & & \\
\hline ICMS a recolher & 60 & \\
\hline a Caixa ou Bancos & & \\
\hline b) pelo valor do incentivo & & \\
\hline ICMS a recolher & 40 & \\
\hline a Receitas Não Operacionais - Doações e subvenções & & \\
\hline c) pela constituição da reserva & & \\
\hline Lucro Líquido do Exercício & & \\
\hline a Reserva de Lucros - Incentivos Fiscais & & \\
\hline
\end{tabular}

O disposto na Lei n. 11.638/2007, no que diz respeito aos incentivos fiscais, embora se aplique aos atos a partir de 1ํ de janeiro de 2008, não alcançando as demonstrações contábeis e suas contabilizações utilizadas neste trabalho, não altera $\mathrm{o}$ entendimento sobre a caracterização do incentivo fiscal, especificamente o incidente sobre o ICMS, concedido pelo modelo industrial Zona Franca de Manaus às empresas industriais ali instaladas.

Quadro 14 - Esquema de contabilização dos incentivos fiscais do ICMS na ZFM

\begin{tabular}{|l|c|c|}
\hline & Débito & Crédito \\
\hline No mês de competência & & \\
\hline ICMS faturado nas Vendas & 100 & \\
\hline a ICMS a recolher & & 100 \\
\hline
\end{tabular}


continuação

\begin{tabular}{|l|c|c|}
\hline Pelo valor do Crédito Estímulo & & \\
\hline ICMS a Recolher & 40 & \\
\hline a ICMS faturado nas Vendas & & 40 \\
\hline No recolhimento do ICMS & & \\
\hline a) pelo valor efetivamente recolhido do imposto & & \\
\hline ICMS a recolher & 60 & \\
\hline a Caixa ou Bancos & & \\
\hline
\end{tabular}

O Quadro 14 mostra uma proposta de contabilização do incentivo fiscal relativo ao ICMS concedido pelo modelo industrial Zona Franca de Manaus. A contabilização do crédito estímulo a débito da conta ICMS a Recolher e a crédito de ICMS faturado nas vendas serve para evidenciar a concessão do incentivo fiscal bem como deixar transparente o fato de que referido incentivo fiscal não está vinculado a investimentos e, sim, como incentivo fiscal para custeio, o que ao ser repassado ao preço, o produto fabricado com esse incentivo chega ao mercado consumidor a um preço mais baixo, reduzindo o ICMS sobre vendas efetivamente recolhido.

Ademais, se o incentivo fiscal concedido pelo ICMS aos produtos fabricados pelas indústrias instaladas na Zona Franca de Manaus fosse reconhecido como para investimento, tratamento semelhante deveria ser dispensado à isenção do IPI e à redução do imposto de importação incidente sobre o imposto de importação suspenso quando da entrada de insumos na Zona Franca de Manaus e que deixa de ser pago por época da venda do produto industrializado para o restante do país. 



\section{METODOLOGIA}

\subsection{Genealogia do estudo e desenho da pesquisa}

A primeira ideia sobre qual tipo de pesquisa desenvolver na área de contabilidade foi sobre tributos, pois, embora esse assunto afete todas as companhias, não existem numerosas pesquisas nessa área. Entretanto, o próprio termo para pesquisa, tributos, é muito amplo e, em geral, a maioria das ideias iniciais é vaga e requerem um maior amadurecimento para se transformar em projetos mais estruturados. Não havia uma ideia clara sobre o que pesquisar e como efetuar uma relação com a contabilidade.

Ao mesmo tempo, como uma das fontes que podem contribuir para a estruturação de ideias são as experiências individuais, nesse contexto, o exercício de atividade profissional, na área tributária, aliada às lacunas existentes e oportunidades de pesquisas a serem desenvolvidas e, em sintonia com as teorias e metodologias existentes, o tema de estudo deste trabalho, a Zona Franca de Manaus, alicerçada nos efeitos dos incentivos fiscais sobre a criação e distribuição de riqueza, foi aos poucos se desenvolvendo por meio de discussões e leituras, até chegar à forma final aqui apresentada.

O ponto de partida foi a pesquisa bibliográfica, na qual foram buscadas as bases para a sustentação deste estudo, principalmente no que diz respeito: i) às políticas de desenvolvimento econômico, em que se buscaram relações com as políticas de desenvolvimento industrial e os modelos de Zonas de Livre Comércio; ii) à teoria de comércio exterior, relacionando-a com políticas de desenvolvimento econômico e incentivos fiscais; iii) à teoria dos stakeholders, criando vínculo entre as partes interessadas e o modelo de demonstração contábil utilizado para medir a criação e distribuição de riqueza. Essa etapa foi contemplada, também, com um levantamento a respeito dos trabalhos realizados sobre o uso da Demonstração de Valor Adicionado nas suas mais diversas aplicações tanto no âmbito internacional quanto no nacional.

A pesquisa documental foi realizada mediante a busca da legislação relacionada à conceituação e importância dos incentivos fiscais, aos incentivos físcais concedidos pelo modelo industrial Zona Franca de Manaus, aos atos normativos relativos aos 
Pronunciamentos Técnicos do CPC 07 e 09, às resoluções do CFC sobre incentivos fiscais e à Demonstração de Valor Adicionado, além de outros.

Em seguida, foi realizada a pesquisa de campo. Essa etapa foi dividida em duas partes: a primeira, com relação à forma de contabilização dos incentivos, na qual foi feita a seleção de 150 (cento e cinqüenta) demonstrações contábeis das empresas industriais instaladas na Zona Franca de Manaus que publicaram tais demonstrações, segundo o banco de dados da Revista Melhores e Maiores, mantido pela FIPECAFI; a segunda, com relação ao levantamento e análise das Demonstrações de Valor Adicionado elaboradas e/ou publicadas pelas empresas industriais instaladas na Zona Franca de Manaus. Foram selecionadas 73 (setenta e três) empresas e a base de dados foi a mesma da FIPECAFI.

Com a utilização do arcabouço teórico, catalogado e estudado nas etapas de pesquisas bibliográfica, documental e de campo, foram utilizados a análise de conteúdo e testes estatísticos para chegar às conclusões deste estudo no que diz respeito às formas de contabilização dos incentivos fiscais e aos efeitos dos incentivos físcais na criação e distribuição de riqueza pelas empresas industriais instaladas na Zona Franca de Manaus.

\subsection{Tipo e método de pesquisa}

A pesquisa desenvolvida neste trabalho pode ser caracterizada como exploratória, descritiva e empírico-analítica. De acordo com Martins (2002, p. 38), ela pode ser exploratória por buscar maiores informações sobre o assunto, além de apresentar os aspectos de pioneirismo na área da Contabilidade e sob o enfoque em que está sendo delineada.

Ao mesmo tempo, caracteriza-se como descritiva por analisar e descrever os procedimentos adotados, principalmente no que diz respeito à primeira parte que trata da contabilização dos incentivos fiscais, especificamente, a contabilização do ICMS pelas empresas industriais beneficiárias de incentivos fiscais instaladas na Zona Franca de Manaus. A pesquisa descritiva observa, analisa e correlaciona fatos ou variáveis sem manipulá-los. Para essa parte, a técnica utilizada é a de análise de conteúdo. 
Por fim, trata-se de pesquisa empírico-analítica quando realiza técnicas de coleta, tratamento e análise de dados marcadamente quantitativos ao utilizar-se de dados de um determinado número de empresas para extrapolar os seus achados para uma população como um todo.

Para Martins (2002, p.26), as abordagens empírico-analíticas são "as que apresentam em comum a utilização de técnicas de coleta, tratamento e análise de dados marcadamente quantitativos." Elas privilegiam estudos práticos e suas propostas possuem caráter técnico, restaurador e incrementalista. Elas possuem uma forte preocupação causal com as variáveis e a validação da prova científica é buscada por meio de testes de instrumentos, graus de significância e sistematização das definições operacionais.

No arcabouço contábil, pode-se classificar essa pesquisa como uma abordagem normativa, quando se busca analisar as formas de contabilização dos incentivos fiscais relativos ao ICMS, e, como uma abordagem positiva, ao providenciar razões para as práticas observadas, por meio de técnicas estatísticas, e predizer fenômenos contábeis não observados, como se enquadram os efeitos dos incentivos fiscais na criação e na distribuição de riqueza, conforme apresentada por Watts e Zimmerman (1986).

Nesse contexto, o presente trabalho utiliza as técnicas estatísticas de regressão linear para análise da criação de riqueza e testes de média para a análise da distribuição de riqueza.

\subsection{Escolha e definição da população-alvo e amostra}

Ao definir o objeto de pesquisa deste trabalho, um grande problema apresentou-se como quase que intransponível: a escassa quantidade de demonstrações contábeis disponíveis das empresas industriais instaladas na Zona Franca de Manaus, uma vez que a maioria delas é constituída sob a forma de sociedade limitada e as principais pertencentes ao capital estrangeiro. Logo, mesmo sendo beneficiárias de incentivos fiscais, elas não possuem a obrigatoriedade de divulgação e/ou publicação desses relatórios, o que não permite à sociedade acompanhar, de forma transparente, os seus desempenhos, quando ela é a permissionária da sua instalação e desenvolvimento das suas operações. 
A SUFRAMA contabiliza o número de 403 empresas com projetos plenos aprovados por aquela autarquia até dezembro de $2008^{56}$, entretanto, muitas dessas empresas se encontram inativas ou são de pequeno porte.

Do total de empresas instaladas na Zona Franca de Manaus foram selecionadas, inicialmente, todas as amazonenses que faziam parte do banco de dados da Revista Melhores e Maiores, da FIPECAFI, para identificar quantas e quais eram. Logo a seguir, foram excluídas as empresas que não se caracterizavam como industriais e beneficiárias de incentivos fiscais concedidos pelo modelo Zona Franca de Manaus. Foram selecionadas, apenas, as empresas industriais. Dessas empresas, foi realizado um primeiro corte, selecionando aquelas cujo faturamento superava US\$ 30 milhões, a US\$ de 31.12.2007, tendo em vista que o banco de dados da Melhores e Maiores Empresas, em determinado ano, só continha empresas acima desse valor.

A fim de equalizar a seleção da amostra por faturamento, adotou-se esse patamar de corte para todos os demais anos. Assim, a Tabela 18 mostra a quantidade e o valor do faturamento dessas empresas industriais instaladas na Zona Franca de Manaus no período de 2003 a 2007. Observe-se que, embora fossem apenas 39 empresas, em 2007, elas representavam 75,9\% do total do faturamento de toda Zona Franca de Manaus.

Tabela 18 - Vendas conjuntas das maiores empresas industriais da Zona Franca de Manaus ${ }^{(1)}$

\begin{tabular}{|c|c|c|c|c|}
\hline Anos & $\begin{array}{l}\text { Quantidade } \\
\text { de empresas }\end{array}$ & $\begin{array}{c}\text { Vendas Conjuntas } \\
\text { (A) }\end{array}$ & $\begin{array}{c}\text { Faturamento } \\
\text { ZFM (B) }\end{array}$ & $\begin{array}{c}\text { Participação } \\
\% \text { (A) / (B) }\end{array}$ \\
\hline 2003 & 43 & 17.566 .945 & 23.296 .039 & $75,4 \%$ \\
\hline 2004 & 47 & 20.253 .442 & 26.118 .935 & $77,5 \%$ \\
\hline 2005 & 48 & 21.848 .667 & 29.168 .898 & $74,9 \%$ \\
\hline 2006 & 39 & 19.985.299 & 30.258 .115 & $66,0 \%$ \\
\hline 2007 & 39 & 21.465 .212 & 28.277 .349 & $75,9 \%$ \\
\hline
\end{tabular}

A Tabela 19 mostra todas as empresas amazonenses (industriais, comerciais e de prestação de serviços) com demonstrações contábeis disponíveis e os seus respectivos faturamentos em relação ao total do faturamento de todas as empresas instaladas na Zona Franca de Manaus, na qual se observa que, em geral, a maior parte do faturamento não é evidenciada por meio das

\footnotetext{
${ }^{56}$ Disponível em www.suframa.gov.br. Acesso em 12.12.2008.
} 
demonstrações contábeis.

Tabela 19 - Empresas amazonenses com demonstrações contábeis disponíveis

\begin{tabular}{c|c|c|c|c}
\hline Anos & Quantidade & $\begin{array}{c}\text { Faturamento Conjunto } \\
\text { em US\$ de 31.12.2007 } \\
\text { (A) }\end{array}$ & $\begin{array}{c}\text { Faturamento Conjunto das } \\
\text { empresas da ZFM em US\$ } \\
\text { de 31.12.2007 (B) }\end{array}$ & (A) / (B) \% \\
\hline 2003 & 52 & 10.843 .648 & 23.296 .039 & 46,55 \\
\hline 2004 & 51 & 14.317 .028 & 26.118 .935 & 54,81 \\
\hline 2005 & 53 & 13.697 .995 & 29.168 .898 & 46,96 \\
\hline 2006 & 49 & 11.768 .822 & 30.258 .115 & 38,89 \\
\hline 2007 & 42 & 12.503 .812 & 28.277 .349 & 44,22 \\
\hline
\end{tabular}

Fonte: Banco de dados Melhores e Maiores, FIPECAFI

Um segundo corte foi feito para permanecerem na amostra as empresas que possuíam demonstrações contábeis publicadas. Dessas, foram selecionadas as quantidades de acordo com a Tabela 20.

Tabela 20 - Empresas industriais amazonenses com demonstrações contábeis disponíveis

\begin{tabular}{c|c|c|c|c}
\hline Anos & Quantidade & $\begin{array}{c}\text { Faturamento Conjunto } \\
\text { em US\$ de 31.12.2007 } \\
\text { (A) }\end{array}$ & $\begin{array}{c}\text { Faturamento Conjunto de } \\
\text { todas as empresas da ZFM } \\
\text { em US\$ de 31.12.2007 (B) }\end{array}$ & (A) / (B) \% \\
\hline 2003 & 42 & 8.405 .232 & 23.296 .039 & 36,08 \\
\hline 2004 & 42 & 11.780 .117 & 26.118 .935 & 45,10 \\
\hline 2005 & 43 & 11.418 .450 & 29.168 .898 & 39,15 \\
\hline 2006 & 38 & 9.147 .019 & 30.258 .115 & 30,23 \\
\hline 2007 & 25 & 10.091 .954 & 28.277 .349 & 35,69 \\
\hline
\end{tabular}

Fonte: Banco de dados Melhores e Maiores, FIPECAFI

Da quantidade de empresas, constantes da Tabela 20, foram selecionadas as que divulgaram as demonstrações contábeis todos os anos, de 2003 a 2007, com faturamento acima de US\$ 30 milhões, perfazendo o total de 26 empresas. Foram acrescentadas à amostra mais 05 (cinco) empresas que divulgaram suas demonstrações contábeis no período de 2003 a 2006 e que, no ano de 2007, tiveram os seus faturamentos estimados, perfazendo o total de 150 (cento e cinquenta) observações. Essas empresas serviram para a análise de cada demonstração contábil, ano a ano, para testar a hipótese auxiliar 1, que trata da forma de contabilização dos incentivos fiscais, especificamente, o ICMS. A Tabela 20 complementa a informação com o valor total do faturamento conjunto das empresas em cada período para demonstrar a ideia da 
magnitude do valor em relação ao total faturado pelas indústrias da Zona Franca de Manaus como um todo.

Após a análise das empresas constantes da Tabela 20, foi efetuado um novo corte para selecionar as empresas industriais amazonenses que elaboram e disponibilizam a Demonstração de Valor Adicionado (DVA).

A Tabela 21 mostra a quantidade de empresas industriais, beneficiárias de incentivos fiscais e instaladas na Zona Franca de Manaus, que elaboram e disponibilizam a Demonstração de Valor Adicionado (DVA). Ao mesmo tempo, complementa a informação com o valor total do faturamento conjunto das empresas em cada período para demonstrar a ideia da magnitude do valor em relação ao total faturado pelas indústrias da Zona Franca de Manaus como um todo.

Tabela 21 - Empresas industriais amazonenses com Demonstração de Valor Adicionado disponíveis em US\$ de 31/12/2007

\begin{tabular}{c|c|c|c|c|c}
\hline Anos & Quantidade & $\begin{array}{c}\text { Faturamento } \\
\text { Conjunto } \\
\text { (A) }\end{array}$ & $\begin{array}{c}\text { Faturamento Conjunto } \\
\text { das Empresas da ZFM } \\
\text { com demonstrações } \\
\text { contábeis (B) }\end{array}$ & $\begin{array}{c}\text { Faturamento } \\
\text { Conjunto de todas } \\
\text { as empresas da } \\
\text { ZFM }\end{array}$ & $\begin{array}{c}\text { (A) / (B) } \\
\%\end{array}$ \\
\hline 2003 & 16 & 3.957 .169 & 8.405 .232 & 23.296 .039 & 47,08 \\
\hline 2004 & 16 & 5.615 .060 & 11.780 .117 & 26.118 .935 & 47,67 \\
\hline 2005 & 15 & 5.369 .296 & 11.418 .450 & 29.168 .898 & 47,02 \\
\hline 2006 & 13 & 4.051 .421 & 9.147 .019 & 30.258 .115 & 44,29 \\
\hline 2007 & 13 & 3.871 .452 & 10.091 .954 & 28.277 .349 & 38,36 \\
\hline
\end{tabular}

(1) Fonte: Suframa

Fonte: Banco de dados Melhores e Maiores, FIPECAFI

As empresas quantificadas na Tabela 21 são as utilizadas para a análise da hipótese geral de pesquisa deste trabalho, que trata da criação e distribuição de riqueza pela Zona Franca de Manaus, bem como para testar as hipóteses auxiliares 2, 3, 4 e 5.

\subsection{Variáveis e definições operacionais}

Com o intuito de fazer com que o entendimento da pesquisa seja mais claro, algumas definições operacionais e das variáveis se tornam necessárias, principalmente no que diz 
respeito às siglas utilizadas e seus significados. O Quadro 15, a seguir, sintetiza as variáveis e suas definições.

Quadro 15 - Definições das variáveis

\begin{tabular}{|l|l|}
\hline \multicolumn{1}{|c|}{ Variável } & \multicolumn{2}{c|}{ Descrição } \\
\hline Valor Adicionado & Valor da riqueza criada pela empresa \\
\hline Vad & Valor adicionado \\
\hline Pes/P & Empregados, Pessoal \\
\hline Gov/G & Governos \\
\hline Acio/A & Proprietários, Acionistas * \\
\hline VadPes & Valor adicionado escalonado pela parcela destinada aos empregados \\
\hline VadGov & Valor adicionado escalonado pela parcela destinada aos governos \\
\hline FatPes & Faturamento escalonado pela parcela destinada aos empregados \\
\hline FatGov & Faturamento escalonado pela parcela destinada aos governos \\
\hline Cont & Formas de contabilização dos incentivos fiscais \\
\hline Con__E & Forma errada de contabilização dos incentivos fiscais \\
\hline Cont_C & Forma correta de contabilização dos incentivos fiscais \\
\hline ZFM_T & Total de empresas industriais da ZFM incluídas na amostra \\
\hline ZFM_E & $\begin{array}{l}\text { Total de empresas industriais da ZFM que contabilizam os incentivos } \\
\text { fiscais de forma errada. }\end{array}$ \\
\hline ZFM_C & $\begin{array}{l}\text { Total de empresas industriais da ZFM que contabilizam os incentivos } \\
\text { fiscais de forma correta. }\end{array}$ \\
\hline FOR_A & Empresas instaladas fora da ZFM do setor autoindústria \\
\hline FOR_B & $\begin{array}{l}\text { Empresas instaladas fora da ZFM do setor de bens de consumo, } \\
\text { indústria digital e eletroeletrônico. }\end{array}$ \\
\hline FOR_T & Total de empresas instaladas fora da ZFM, incluídas na amostra. \\
\hline PARES & $\begin{array}{l}\text { Empresas pares, formadoras do grupo de controle, instaladas fora da } \\
\text { ZFM. }\end{array}$ \\
\hline
\end{tabular}

* Escolhida a letra A/Acio para diferenciar de pessoal (P).

\subsection{Procedimentos de coleta de dados}

As demonstrações contábeis que serviram para analisar as formas de contabilização dos incentivos fiscais foram coletadas do banco de dados da FIPECAFI, mantido para elaboração da Revista Melhores e Maiores. Foram coletadas 190 (cento e noventa) demonstrações contábeis, conforme Tabela 20 e, dessas, selecionadas 150 (cento e cinqüenta) para análise, com valores de faturamento acima de U\$ 30 milhões a US\$ de 31.12.2007, sendo 25 empresas que divulgaram as suas demonstrações contábeis durante os anos de 2003 a 2007 e mais 05 que as divulgaram durante os anos de 2003 a 2006 e tiveram o faturamento estimado para o ano de 2007. 
Com relação ao estudo e análise da criação e distribuição de riqueza, primeiramente, foram coletadas todas as Demonstrações de Valor Adicionado das empresas instaladas na Zona Franca de Manaus do banco de dados da FIPECAFI, mantido para a elaboração da Revista Melhores e Maiores. Desse total, foram selecionadas, apenas, aquelas elaboradas e/ou publicadas pelas empresas industriais, perfazendo um total de 73 (setenta e três).

Do mesmo banco de dados mantido pela FIPECAFI, foram selecionadas as Demonstrações de Valor Adicionado das empresas industriais utilizadas como grupo de controle, conforme quantidades e características apresentadas no Quadro 15.

O período escolhido foi de cinco anos, iniciando com as demonstrações contábeis de 2003 e terminando com as de 2007. Fica o registro de que a escolha desse período foi em decorrência de a Demonstração de Valor Adicionado (DVA) deixar de ser voluntária e passar a obrigatória para as Companhias Abertas, conforme preceitua a Lei n. 11.638, sancionada em 28 de dezembro de 2007, com vigência a partir de $1^{\text {o }}$ de janeiro de 2008. Além do mais, credite-se o fato de o pesquisador considerar esse período suficiente para responder à questão de pesquisa proposta e atender aos objetivos definidos.

\subsection{Grupo de controle}

As empresas industriais instaladas na Zona Franca de Manaus possuem características singulares e, em decorrência, principalmente, dos incentivos fiscais praticados naquela região, torna-se difícil encontrar empresas similares em outras regiões do país que atuem nos mesmos setores, sem incentivos fiscais. Tal afirmativa é reforçada pelo fato de que as indústrias instaladas naquela região são responsáveis por, praticamente, a totalidade da produção nacional nos seus respectivos setores, como: televisores, motocicletas, autorradio e aparelhos de reprodução de som, aparelhos de telefonia celular, relógios, fornos de microondas, condicionadores de ar, aparelhos de barbear, dentre outros.

Diante dessa constatação e para atender aos objetivos deste trabalho, a solução encontrada foi a utilização de setores aos quais pertencem empresas similares que foram consideradas como proxies das indústrias instaladas na Zona Franca de Manaus e selecionadas na amostra. 
Inicialmente, foram selecionados os setores de autoindústria, de bens de consumo, de indústria digital e eletroeletrônica por serem considerados os mais próximos dentre os diversos constantes do banco de dados da FIPECAFI. Foram excluídas as empresas que não apresentavam similaridades de produção, setor, estrutura, dentre outros. As empresas restantes, por possuírem um reduzido número de observações, foram reunidas em dois grupos:

- Grupo 1: setor de autoindústria, com 13 observações e

- Grupo 2: setor de bens de consumo, indústria digital e eletroeletrônica, com 24 observações.

Beloque (2008, p. 52) utilizou a técnica de empresas pares na formação de um grupo de controle de empresas norte-americanas que possuíssem características similares aos seus pares brasileiros. Para isso, foi selecionada a empresa norte-americana que estivesse mais próxima da empresa brasileira, conforme os critérios definidos.

A fim de fornecer uma maior robustez à análise, uma vez que o número de observações dos setores reunidos, nos grupos 1 e 2, é muito reduzido, foi formado um grupo de controle de empresas industriais instaladas fora da Zona Franca de Manaus para servirem como empresas pares, cuja seleção foi realizada de acordo com os seguintes critérios:

i. Setor econômico: as empresas pertencem ao mesmo setor econômico ou a setor similar ou correlacionado;

ii. Tamanho: pelo valor do faturamento, em US\$ mil de 31/12/2007.

As relações das empresas pares selecionadas com os seus respectivos setores e faturamentos, para o período de 2003 a 2007, encontram-se no Apêndice 7. O Quadro 16, a seguir, sintetiza os grupos de empresas selecionadas para os objetos de pesquisas e os grupos de empresas consideradas como grupos de controle bem como as técnicas utilizadas. 
Quadro 16 - Síntese dos objetos de pesquisa, grupos de pesquisas e de controle

\begin{tabular}{|c|c|c|c|c|c|}
\hline $\begin{array}{l}\text { Objeto de } \\
\text { pesquisa }\end{array}$ & $\begin{array}{l}\text { Grupo de } \\
\text { empresas }\end{array}$ & $\begin{array}{l}\text { Número } \\
\text { de obs. }\end{array}$ & $\begin{array}{l}\text { Grupos escolhidos / divididos } \\
\text { / pares a serem comparados }\end{array}$ & $\begin{array}{l}\text { Número } \\
\text { de obs. }\end{array}$ & $\begin{array}{c}\text { Técnica } \\
\text { utilizada }\end{array}$ \\
\hline \multirow{2}{*}{$\begin{array}{c}\text { Contabilização } \\
\text { dos Incentivos } \\
\text { Fiscais }\end{array}$} & \multirow{2}{*}{$\begin{array}{l}\text { Empresas da } \\
\text { ZFM }\end{array}$} & \multirow{2}{*}{150} & $\begin{array}{l}\text { Empresas da ZFM que } \\
\text { contabilizam de forma correta }\end{array}$ & $*$ & \multirow{2}{*}{$\begin{array}{l}\text { Análise } \\
\text { de } \\
\text { conteúdo }\end{array}$} \\
\hline & & & $\begin{array}{l}\text { Empresas da ZFM que } \\
\text { contabilizam de forma errada }\end{array}$ & $*$ & \\
\hline \multirow{11}{*}{$\begin{array}{l}\text { Criação de } \\
\text { riqueza }\end{array}$} & \multirow{4}{*}{$\begin{array}{l}\text { Empresas da } \\
\text { ZFM }\end{array}$} & \multirow{4}{*}{73} & Setores totais $(\mathrm{A}+\mathrm{B})$ & 37 & \multirow{11}{*}{$\begin{array}{c}\text { Regressão } \\
\text { Linear e } \\
\text { Testes de } \\
\text { médias }\end{array}$} \\
\hline & & & Setor de autoindústria (A) & 13 & \\
\hline & & & $\begin{array}{l}\text { Setor Bens de consumo, Ind. } \\
\text { Digital e Eletroeletrônico (B) }\end{array}$ & 24 & \\
\hline & & & Empresas pares & 73 & \\
\hline & \multirow{4}{*}{$\begin{array}{l}\text { Empresas da } \\
\text { ZFM que } \\
\text { contabilizam os } \\
\text { incentivos } \\
\text { fiscais de forma } \\
\text { correta }\end{array}$} & \multirow{4}{*}{19} & $\begin{array}{l}\text { Empresas da ZFM que } \\
\text { contabilizam de forma errada }\end{array}$ & 54 & \\
\hline & & & Setores totais $(\mathrm{A}+\mathrm{B})$ & 37 & \\
\hline & & & Setor de autoindústria (A) & 13 & \\
\hline & & & $\begin{array}{l}\text { Setor Bens de consumo, Ind. } \\
\text { Digital e Eletroeletrônico (B) }\end{array}$ & 24 & \\
\hline & \multirow{3}{*}{$\begin{array}{l}\text { Empresas da } \\
\text { ZFM que } \\
\text { contabilizam os } \\
\text { incentivos } \\
\text { fiscais de forma } \\
\text { errada }\end{array}$} & \multirow{3}{*}{54} & Setores totais $(\mathrm{A}+\mathrm{B})$ & 37 & \\
\hline & & & Setor de autoindústria (A) & 13 & \\
\hline & & & $\begin{array}{l}\text { Setor Bens de consumo, Ind. } \\
\text { Digital e Eletroeletrônico (B) }\end{array}$ & 24 & \\
\hline \multirow{11}{*}{$\begin{array}{l}\text { Distribuição } \\
\text { de riqueza } \\
\text { - Pessoal } \\
\text {-Governos } \\
\text {-Proprietários }\end{array}$} & \multirow{4}{*}{$\begin{array}{l}\text { Empresas da } \\
\text { ZFM }\end{array}$} & \multirow{4}{*}{73} & Setores totais $(\mathrm{A}+\mathrm{B})$ & 37 & \multirow{11}{*}{$\begin{array}{l}\text { Testes de } \\
\text { médias }\end{array}$} \\
\hline & & & Setor de autoindústria (A) & 13 & \\
\hline & & & $\begin{array}{l}\text { Setor Bens de consumo, Ind. } \\
\text { Digital e Eletroeletrônico (B) }\end{array}$ & 24 & \\
\hline & & & Empresas pares & 73 & \\
\hline & \multirow{4}{*}{$\begin{array}{l}\text { Empresas da } \\
\text { ZFM que } \\
\text { contabilizam os } \\
\text { incentivos } \\
\text { fiscais de forma } \\
\text { correta }\end{array}$} & \multirow{4}{*}{19} & $\begin{array}{l}\text { Empresas da ZFM que } \\
\text { contabilizam de forma errada }\end{array}$ & 54 & \\
\hline & & & Setores totais $(\mathrm{A}+\mathrm{B})$ & 37 & \\
\hline & & & Setor de autoindústria (A) & 13 & \\
\hline & & & $\begin{array}{l}\text { Setor Bens de consumo, Ind. } \\
\text { Digital e Eletroeletrônico (B) }\end{array}$ & 24 & \\
\hline & \multirow{3}{*}{$\begin{array}{c}\text { Empresas da } \\
\text { ZFM que } \\
\text { contabilizam os } \\
\text { incentivos } \\
\text { fiscais de forma } \\
\text { errada }\end{array}$} & \multirow{3}{*}{54} & Setores totais $(\mathrm{A}+\mathrm{B})$ & 37 & \\
\hline & & & Setor de autoindústria (A) & 13 & \\
\hline & & & $\begin{array}{l}\text { Setor Bens de consumo, Ind. } \\
\text { Digital e Eletroeletrônico (B) }\end{array}$ & 24 & \\
\hline
\end{tabular}

* Objeto de pesquisa e análise

\subsection{Tratamento dos dados}

A amostra escolhida para a pesquisa foi selecionada do banco de dados da FIPECAFI, utilizado para a elaboração da Revista Melhores e Maiores, no período de 2003 a 2007. Tratase, portanto, de uma amostra não probabilística, que, na visão de Stevenson (1981), é uma 
amostragem por julgamento, subjetiva e, de acordo com Mattar (1996, p.132), essa amostra é definida como aquela em que a seleção dos elementos da população para compor a amostra depende, ao menos em parte do julgamento do pesquisador.

Os valores das demonstrações contábeis encontram-se expressos em US\$ do dia 31 de dezembro de 2007. As quantias referentes às distribuições de riqueza de cada uma das empresas (Pessoal, Tributos, Juros e Aluguéis e Proprietários) foram divididas pelo valor adicionado total a distribuir. A opção pela utilização em percentual justifica-se para eliminar o efeito tamanho/porte das empresas.

Os dados, utilizados nesta tese, foram trabalhados de duas maneiras. Na primeira, para a forma de contabilização dos incentivos fiscais, especificamente, o ICMS, foram trabalhados com a utilização da técnica de análise de conteúdo. Nessa parte, foram analisadas 150 (cento e cinquenta) demonstrações contábeis para verificar a forma de contabilização desses incentivos fiscais pelas empresas industriais instaladas na Zona Franca de Manaus. Na segunda, com relação à criação e à distribuição de riqueza pela Zona Franca de Manaus, foram trabalhados com o auxílio das técnicas estatísticas de regressão linear e teste de médias.

Para a análise de criação e de distribuição de riqueza pela Zona Franca de Manaus foram selecionadas as DVAs publicadas no período de 2003 a 2007, perfazendo um total de 73 observações. A criação e a distribuição de riqueza das empresas que estão instaladas na Zona Franca de Manaus foram comparadas com as empresas/grupos de controle constantes do Quadro 16.

Embora as indústrias instaladas na Zona Franca de Manaus pertençam a setores industriais diferentes, assumiu-se a premissa de considerá-las como pertencentes a um único setor, ou seja, toda a ZFM como um setor único, uma vez que, embora apresentem estruturas de custos e produção diferentes, elas apresentam estruturas de incentivos fiscais semelhantes, não afetando a análise pretendida. Vale destacar o fato de que nem todas as empresas apresentaram demonstrações contábeis publicadas e demonstrações de valor adicionado para todos os anos do período pesquisado. 


\subsubsection{Análise de conteúdo}

Bardin (1977, p. 38) define a análise de conteúdo como "um conjunto de técnicas de análise das comunicações, que utiliza procedimentos sistemáticos e objetivos de descrição do conteúdo das mensagens." Apresenta a análise de conteúdo como um tratamento da informação contida nas mensagens e diz que é conveniente precisar, de imediato, que, em muitos casos, a análise não se limita ao conteúdo. Acrescenta que

\footnotetext{
A análise de conteúdo pode ser uma análise dos "significados", embora possa ser também uma análise dos "significantes", ou seja, uma análise dos procedimentos. Por outro lado, o tratamento descritivo constitui um primeiro tempo do procedimento, mas não é exclusivo da análise de conteúdo. (Ibid., p. 34).
}

A análise de conteúdo é um método que busca informações com a característica de sistematizar os dados para a interpretação de um fenômeno estudado. Vergara (2006) diz que o método de análise de conteúdo se encaixa tanto para fins exploratórios como para a verificação de hipóteses ou suposições preestabelecidas.

Para Martins e Theóphilo (2007, p. 95), “A análise de conteúdo é uma técnica para se estudar e analisar a comunicação de maneira objetiva e sistemática. Buscam-se inferências confiáveis de dados e informações com respeito a determinado contexto, a partir dos discursos escritos ou orais de seus atores e/ou autores."

Dentre os seus principais usos, Martins e Theóphilo (2007, p. 96) destacam que a análise de conteúdo se utiliza da técnica de "Auditar conteúdos de comunicações e compará-los com padrões, ou determinados objetivos."

As demonstrações contábeis podem ser consideradas como instrumentos de comunicação da situação patrimonial e financeira das empresas e, sendo a análise de conteúdo considerada como um conjunto de técnicas de análise de comunicações, daí, a opção por essa técnica para decifrar os significados das mensagens das demonstrações contábeis e analisar a forma de contabilização dos incentivos fiscais, especificamente, o ICMS, pelas indústrias instaladas na Zona Franca de Manaus.

Partindo-se da ideia de Bardin (1977, p. 34) de que "a descrição analítica funciona segundo procedimentos sistemáticos e objetivos de descrição do conteúdo das mensagens", as 150 
(cento e cinqüenta) demonstrações contábeis publicadas, selecionadas no período de 2003 a 2007, foram analisadas nos seguintes itens:

- Informações constantes das notas explicativas: para verificar se a empresa informava o tratamento dado aos incentivos fiscais do ICMS e à sua forma de contabilização;

- Demonstração de Resultado do Exercício: para verificar o valor considerado como ICMS sobre venda, outras receitas não operacionais etc.;

- Balanço Patrimonial: para verificar as contas de ativo e passivo sobre possíveis contas vinculadas para aplicação, obrigações de contrapartida de investimentos e reserva de capital - subvenção para investimento, e

- Demonstração de Mutação do Patrimônio Líquido: para verificar a distribuição e contabilização dos lucros líquidos e demais contas do patrimônio líquido.

\subsubsection{Regressão linear}

Para Corrar e Theóphilo (2004, p. 75), a regressão linear "consiste em determinar uma função matemática que busca descrever o comportamento de determinada variável dependente com base nos valores de uma ou mais variáveis independentes." É nesse contexto que a utilização dessa técnica estatística é usada para determinar a criação de valor adicionado (variável dependente) em função do faturamento (variável independente).

A função da regressão linear é a seguinte:

$$
Y_{i}=\alpha+\beta X_{i}+\varepsilon_{i} \quad \text { Equação 02, }
$$

em que:

$Y_{i}=$ variável dependente;

$\alpha=$ coeficiente linear ou intercepto da reta; ponto em que a reta de regressão intercepta o eixo vertical $\mathrm{Y}$, quando $\mathrm{X}_{\mathrm{i}}$ é igual a zero;

$\beta=$ coeficiente angular ou declividade da reta;

$X_{i}=$ variável independente e

$\mathcal{E}_{i}=$ erro estatístico. 
Traduzindo a função da regressão linear para o propósito deste trabalho, tem-se a seguinte equação:

$$
V a d=\alpha+\beta F a t+\varepsilon \quad \text { Equação 03, }
$$

em que:

Vad = estimativa da variável dependente valor adicionado (riqueza criada);

$\alpha=$ parâmetro estatístico; estimativa do coeficiente linear; ponto em que a reta de regressão intercepta o eixo vertical $\mathrm{Y}$, quando $\mathrm{X}_{\mathrm{i}}$ é igual a zero;

$\beta$ = parâmetro estatístico, estimativa do coeficiente angular;

Fat = faturamento; valor amostral da variável explicativa Vad e

$\mathcal{E}=$ parâmetro estatístico.

Segundo Gujarati (2006, p. 24), um dos objetivos do modelo de regressão linear é "estimar e/ou prever o valor médio da variável dependente com base no valor conhecido ou fixado das variáveis explanatórias." Logo, busca-se estimar o valor adicionado, a criação de riqueza, (variável dependente) em função do faturamento das empresas (variável independente).

Um ponto a ser observado, na análise de regressão, é a correlação entre as variáveis utilizadas no modelo. Para Stevenson (1981, p. 341) e Corrar e Theóphilo (2004, p. 7), a análise de correlação procura medir a força, ou grau, de relacionamento entre duas variáveis. Nesse aspecto, é desejável que a correlação entre as variáveis dependentes e independentes seja elevada, quanto mais próxima de 1,00 , melhor.

Outro aspecto a ser considerado é o coeficiente de determinação do modelo $\left(\mathrm{R}^{2}\right)$ que, segundo Corrar e Theóphilo (2004, p. 92), "mede o grau de ajustamento da reta de regressão aos dados observados. Indica a proporção da variável total da variável dependente que é explicada pela variação da variável independente" e Stock e Watson (2004, p. 84) afirmam que "um $\mathrm{R}^{2}$ próximo de um indica que o regressor é bom na previsão de Yi”, ou seja, quanto mais próximo de um for o coeficiente de determinação, maior é a explicação da variação total da variável dependente em relação à variação da independente. 
Quando a dispersão em torno da reta de regressão é pequena em relação à variação total dos valores de y (variável dependente) em torno de sua média, isso significa que a variação explicada responde por uma elevada percentagem da variação total e o $\mathrm{r}^{2}$ (coeficiente de determinação) estará muito mais próximo de 1,00.

\subsubsection{Teste de médias}

Segundo Stevenson (1981, p. 222), o teste de hipóteses permite verificar as afirmações a respeito das médias populacionais a partir das amostras disponíveis, considerando uma região de aceitação e outra de rejeição a partir do nível de confiança estabelecido.

Tais testes podem ser paramétricos, quando a população da qual a amostra foi extraída possui distribuição normal e variâncias equivalentes e a amostra é aleatória e independente ou não paramétrica, para as amostras que não se enquadram em pelo menos um dos pressupostos necessários às análises paramétricas. (STEVENSON, 1981, p. 254; MERINO; DIAZ, 2002).

A análise de variância é uma técnica estatística que pode ser usada para saber se as médias de duas ou mais populações são iguais. Se, ao aplicar esse teste, levar à não rejeição da hipótese nula, é possível concluir que as diferenças envolvidas entre as médias amostrais são devidas a variações aleatórias na amostra e que as populações são iguais. No caso de rejeição, concluise que as diferenças entre as médias amostrais são demasiadamente grandes para serem relacionadas apenas à chance.

Para fazer uso do teste de análise de variância, Stevenson (1981) estipula três pré-requisitos a serem seguidos:

- As amostras devem ser aleatórias e independentes;

- As amostras devem ser extraídas de populações com distribuições normais e

- $\quad$ As populações devem ter variâncias iguais.

$\mathrm{O}$ teste $\mathrm{t}$ caracteriza-se como uma alternativa para a comparação de médias em amostras independentes. Trata-se de teste paramétrico com a exigência dos seguintes pressupostos:

- $\quad$ Têm-se duas amostras $\mathrm{X}_{1}, \ldots, \mathrm{X}_{\mathrm{n}}, \mathrm{Y}_{1}, \ldots, \mathrm{Y}_{\mathrm{n}}$ independentes; 
- Cada amostra deve ser constituída por observações independentes e retiradas da mesma população (amostras aleatórias) e

- As duas populações devem ter distribuição Normal com as variâncias desconhecidas mas iguais.

- $\quad$ As hipóteses a serem testadas são do tipo:

$$
\begin{aligned}
& \mathrm{H}_{0}: \mu \mathrm{x}=\mu \mathrm{y} \\
& \mathrm{H}_{1}: \mu \mathrm{x} \neq \mu \mathrm{y}
\end{aligned}
$$

Dessa forma, o teste busca testar a seguinte hipótese:

$$
\begin{aligned}
& \mathrm{H}_{0} \text { : Não há diferença entre os grupos. } \\
& \mathrm{H}_{1} \text { : Há diferença. }
\end{aligned}
$$

Ao reforçar os pressupostos desse teste, Pestana (2000, p. 159) diz que "o teste t para amostras de dimensão inferiores ou iguais a 30, exigem que o(s) grupo(s) em análise tenha(m) distribuição normal."

Se esses requisitos não forem cumpridos, uma alternativa é a utilização de testes não paramétricos. Maroco (2003, p.169) sugere quando é indicado usar um teste não paramétrico:

[...] os testes não-paramétricos são considerados geralmente como alternativa aos testes paramétricos quando as condições de aplicação destes, nomeadamente a normalidade da variável sob estudo e a homogeneidade de variâncias entre os grupos, não se verificam. Os testes nãoparamétricos não exigem que a distribuição da variável sob estudo seja conhecida (normal).

De acordo com Martins (2005, p. 216):

Os testes não-paramétricos são particularmente úteis para decisões sobre dados oriundos de pesquisas da área de ciências humanas. Para aplicá-los, não é necessário admitir hipóteses sobre distribuições de probabilidades da população da qual tenham sido extraídas amostras para análise.

Um desses testes é o de Kruskal Wallis, definido por Stevenson (1981) como um método alternativo para testar se três ou mais amostras independentes foram extraídas de populações com médias iguais. A hipótese nula desse teste diz que as médias dos grupos são iguais. Nesse caso, ao rejeitar a hipótese nula, pode-se concluir, de acordo com Maroco (2003), que existe, pelo menos, uma média populacional que é significativamente diferente das restantes. 
Outra alternativa é o teste de Mann-Whitney. Trata-se de um teste não paramétrico, uma vez que as variáveis não atenderam aos pressupostos necessários à utilização de um teste paramétrico, tais como a normalidade e homogeneidade de variância, que visa identificar se duas amostras independentes provêm de populações com médias iguais, ao nível de significância $^{57}$ preestabelecido. Esse teste consiste na atribuição de postos às observações, como se essas fizessem parte de uma única amostra. Se a hipótese nula não for rejeitada, então, os postos baixos, médios e altos estariam distribuídos, equilibradamente, entre as duas amostras.

A respeito do teste de Mann-Whitney, Martins (2005, p. 269) afirma que:

\begin{abstract}
é usado para testar se duas amostras independentes foram retiradas de populações com médias iguais. Trata-se de uma interessante alternativa ao teste paramétrico para igualdade de médias (teste t), pois Mann-Whitney não exige nenhuma hipótese sobre distribuições populacionais e suas variâncias.
\end{abstract}

Em seguida, Fávero et al. (2009, p. 163) afirmam que o teste de Mann-Whitney é aplicado para testar se duas amostras independentes foram extraídas de populações com médias iguais. Acrescenta que se trata de um dos testes não paramétricos mais poderosos, sendo uma alternativa ao teste paramétrico $t$ para duas amostras independentes quando a amostra for pequena e/ou quando a hipótese de normalidade for violada.

\footnotetext{
${ }^{57}$ Nível de significância, $\alpha$, representa a probabilidade de cometer o erro tipo I, ou seja, rejeitar a hipótese nula, quando ela é verdadeira. Stevenson (1981, p. 228).
} 



\section{TRATAMENTO E ANÁLISE DOS DADOS}

Nesse capítulo, são apresentados e discutidos os resultados obtidos. Dividem-se em três partes: a) a primeira mostra os achados sobre a forma de contabilização dos incentivos fiscais, especificamente, o ICMS, pelas indústrias instaladas na Zona Franca de Manaus; b) são apresentados e comparados os resultados da criação de riqueza pelas empresas industriais instaladas na Zona Franca de Manaus com os dos grupos de controle selecionados, por meio das técnicas estatísticas de regressão linear e teste de médias, e c) da mesma forma, e por meio da técnica estatística de teste de média, são apresentados e comparados os resultados da distribuição dessa riqueza entre os grupos pessoal, governos e proprietários, considerados como os principais stakeholders para os propósitos deste trabalho.

\subsection{Contabilização dos incentivos fiscais}

A Tabela 22 mostra a quantidade de empresas industriais instaladas na Zona Franca de Manaus que divulgam as suas demonstrações contábeis, o seu faturamento conjunto e a sua proporção em relação ao faturamento total da Zona Franca de Manaus no período de 2003 a 2007.

Tabela 22 - Empresas da ZFM que divulgaram as demonstrações contábeis - 2003-2007

\begin{tabular}{c|c|c|c|c}
\hline Anos & $\begin{array}{c}\text { Quantidade de } \\
\text { Empresas }\end{array}$ & $\begin{array}{c}\text { Faturamento } \\
\text { Conjunto (A) }\end{array}$ & $\begin{array}{c}\text { Faturamento da } \\
\text { ZFM (B) }\end{array}$ & (A) / (B) \% \\
\hline 2003 & 31 & 8.244 .953 & 23.296 .039 & 35,39 \\
2004 & 36 & 11.663 .876 & 26.118 .935 & 44,66 \\
2005 & 37 & 11.292 .658 & 29.168 .898 & 38,71 \\
2006 & 29 & 8.951 .116 & 30.258 .115 & 29,58 \\
2007 & 25 & 10.091 .954 & 28.277 .349 & 35,69 \\
\hline
\end{tabular}

(1) Valores em US\$ de 31.12.2007.

Fonte: Banco de dados FIPECAFI/Melhores e Maiores Exame 
Dessas demonstrações contábeis, foram analisadas 150 (cento e cinquenta) para testar a hipótese auxiliar 1, que estabelece:

\section{HA1: As empresas industriais, instaladas na Zona Franca de Manaus e beneficiadas com incentivos fiscais, que publicam as demonstrações contábeis, contabilizam os incentivos fiscais de maneira incorreta.}

A análise de conteúdo foi escolhida por ser um método que pode ser utilizado para a verificação de hipóteses ou suposições preestabelecidas, conforme Vergara (2006), e, também, por funcionar, segundo procedimentos sistemáticos e objetivos, como uma forma de descrição do conteúdo das mensagens. (BARDIN, 1977, p. 34).

Ao analisar os balanços publicados pelas empresas industriais beneficiárias de incentivos fiscais concedidos pelo modelo Zona Franca de Manaus, foram encontradas quatro situações a respeito da contabilização dos incentivos fiscais do ICMS, sintetizadas no Quadro 17.

Quadro 17 - Descrição das formas de contabilização do incentivo fiscal do ICMS

\begin{tabular}{|c|l|}
\hline $\begin{array}{c}\text { Formas de } \\
\text { Contabilização }\end{array}$ & \multicolumn{1}{c|}{ Descrição } \\
\hline A & $\begin{array}{l}\text { O ICMS é considerado como parte das deduções sobre a Receita } \\
\text { Bruta pelo seu valor integral; } \\
\text { A parcela referente ao incentivo fiscal é contabilizada como } \\
\text { Reserva de Capital - Subvenção para Investimento. }\end{array}$ \\
\hline B & $\begin{array}{l}\text { O valor do incentivo fiscal diminui o valor do ICMS constante } \\
\text { das deduções da Receita Bruta, já calculados quando da sua } \\
\text { apuração. }\end{array}$ \\
\hline C & $\begin{array}{l}\text { O ICMS é considerado como parte das deduções sobre a Receita } \\
\text { Bruta pelo seu valor integral; } \\
\text { A parcela referente ao incentivo fiscal é contabilizada como } \\
\text { "Outras Receitas Operacionais". }\end{array}$ \\
\hline D & $\begin{array}{l}\text { O ICMS é considerado como parte das deduções sobre a Receita } \\
\text { Bruta pelo seu valor integral; } \\
\text { Não há informações quanto à forma de contabilização do } \\
\text { incentivo fiscal. }\end{array}$ \\
\hline SI & Sem informação; Não se têm demonstrações contábeis. \\
\hline
\end{tabular}


A Tabela 23 elenca as empresas industriais cujas demonstrações contábeis foram analisadas, codificadas por uma numeração sequencial, e o seu faturamento bruto no ano de 2007. Nas colunas em que constam os anos, são catalogadas as formas de contabilização dos incentivos fiscais relativos ao ICMS, em consonância com as encontradas no Quadro 17.

Tabela 23 - Formas de contabilização dos incentivos fiscais

\begin{tabular}{|c|c|c|c|c|c|c|}
\hline \multirow{2}{*}{ Código } & \multirow{2}{*}{$\begin{array}{c}\text { Faturamento } \\
\text { Bruto de } 2007 \\
\text { (Em US\$ mil de } \\
\text { 31.12.2007) }\end{array}$} & \multicolumn{5}{|c|}{ Formas de Contabilização } \\
\hline & & 2003 & 2004 & 2005 & 2006 & 2007 \\
\hline IND.001 & 2.373 .614 & $\mathrm{D}$ & $\mathrm{D}$ & SI & SI & A \\
\hline IND.002 & 1.377 .139 & $\mathrm{D}$ & $\mathrm{D}$ & $\mathrm{D}$ & $\mathrm{D}$ & $\mathrm{D}$ \\
\hline IND.003 & 1.122 .029 & SI & SI & SI & $\mathrm{B}$ & B \\
\hline IND.004 & 786.568 & $\mathrm{C}$ & B & B & $\mathrm{B}$ & B \\
\hline IND.005 & 715.431 & A & $\mathrm{B}$ & $\mathrm{B}$ & $\mathrm{B}$ & B \\
\hline IND.006 ${ }^{(1)}$ & 640.765 & $\mathrm{C}$ & $\mathrm{C}$ & $\mathrm{C}$ & SI & SI \\
\hline IND.007 & 534.268 & $\mathrm{D}$ & $\mathrm{D}$ & $\mathrm{D}$ & $\mathrm{D}$ & $\mathrm{D}$ \\
\hline IND.008 & 525.626 & A & A & A & A & A \\
\hline IND.009 ${ }^{(1)}$ & 451.160 & SI & A & A & SI & SI \\
\hline IND.010 & 448.836 & A & A & A & A & SI \\
\hline IND.011 & 397.733 & A & A & A & A & SI \\
\hline IND.012 & 375.306 & SI & SI & A & A & A \\
\hline IND.013 & 335.963 & $\mathrm{~A}$ & A & A & A & A \\
\hline IND.014 & 312.167 & B & $\mathrm{B}$ & B & B & B \\
\hline IND.015 & 266.844 & A & A & A & A & A \\
\hline IND.016 & 224.529 & $\mathrm{C}$ & $\mathrm{C}$ & $\mathrm{C}$ & $\mathrm{C}$ & $\mathrm{C}$ \\
\hline IND.017 & 223.078 & A & A & A & A & A \\
\hline IND.018 & 221.773 & A & A & A & A & A \\
\hline IND.019 & 208.622 & SI & SI & A & A & A \\
\hline IND.020 & 175.853 & SI & SI & B & B & B \\
\hline IND.021 & 149.894 & SI & A & A & A & A \\
\hline IND.022 & 125.633 & SI & SI & SI & SI & A \\
\hline IND.023 & 103.136 & A & A & A & A & A \\
\hline IND.024 & 98.309 & $\mathrm{C}$ & $\mathrm{D}$ & $\mathrm{D}$ & $\mathrm{C}$ & $\mathrm{C}$ \\
\hline IND.025 & 91.489 & A & A & A & A & A \\
\hline IND.026 & 88.502 & $\mathrm{~A}$ & A & A & A & A \\
\hline IND.027 & 69.628 & A & A & A & A & A \\
\hline IND.028 & 45.568 & A & A & A & A & A \\
\hline IND.029 & 38.863 & $\mathrm{C}$ & B & B & B & B \\
\hline IND.030 & 36.390 & A & $\mathrm{A}$ & A & A & A \\
\hline
\end{tabular}

(1) Estimativa

Fonte: FIPECAFI. Melhores e Maiores 
A Tabela 24 mostra o percentual das empresas industriais instaladas na ZFM de acordo com as formas de contabilização dos incentivos fiscais, especificamente, o ICMS. Destaque-se o crescimento da forma "B", no período, considerada, neste trabalho, como a forma correta de contabilização, partindo de $3,33 \%$, no ano de 2003 , para $20,00 \%$, no ano de 2007 , embora a parcela que o contabiliza, de forma incorreta, represente 66,67\% em 2007.

Tabela 24 - Distribuição percentual das empresas industriais da ZFM de acordo com as formas de contabilização dos incentivos fiscais (\%)

\begin{tabular}{c|c|c|c|c|c}
\hline Formas & $\mathbf{2 0 0 3}$ & $\mathbf{2 0 0 4}$ & $\mathbf{2 0 0 5}$ & $\mathbf{2 0 0 6}$ & $\mathbf{2 0 0 7}$ \\
\hline $\mathbf{A}$ & 46,67 & 50,00 & 56,67 & 53,33 & 53,33 \\
$\mathbf{B}$ & 3,33 & 13,33 & 16,67 & 20,00 & 20,00 \\
$\mathbf{C}$ & 16,67 & 6,67 & 6,67 & 6,67 & 6,67 \\
$\mathbf{D}$ & 10,00 & 13,33 & 10,00 & 6,67 & 6,67 \\
SI & 23,33 & 16,67 & 10,00 & 13,33 & 13,33 \\
\hline TOTAL & $\mathbf{1 0 0 , 0 0 \%}$ & $\mathbf{1 0 0 , 0 0 \%}$ & $\mathbf{1 0 0 , 0 0 \%}$ & $\mathbf{1 0 0 , 0 0 \%}$ & $\mathbf{1 0 0 , 0 0 \%}$ \\
\hline
\end{tabular}

No Gráfico 4, fica ressaltada, de forma mais nítida, a evolução da forma de contabilização dos incentivos fiscais de forma correta (Forma B).

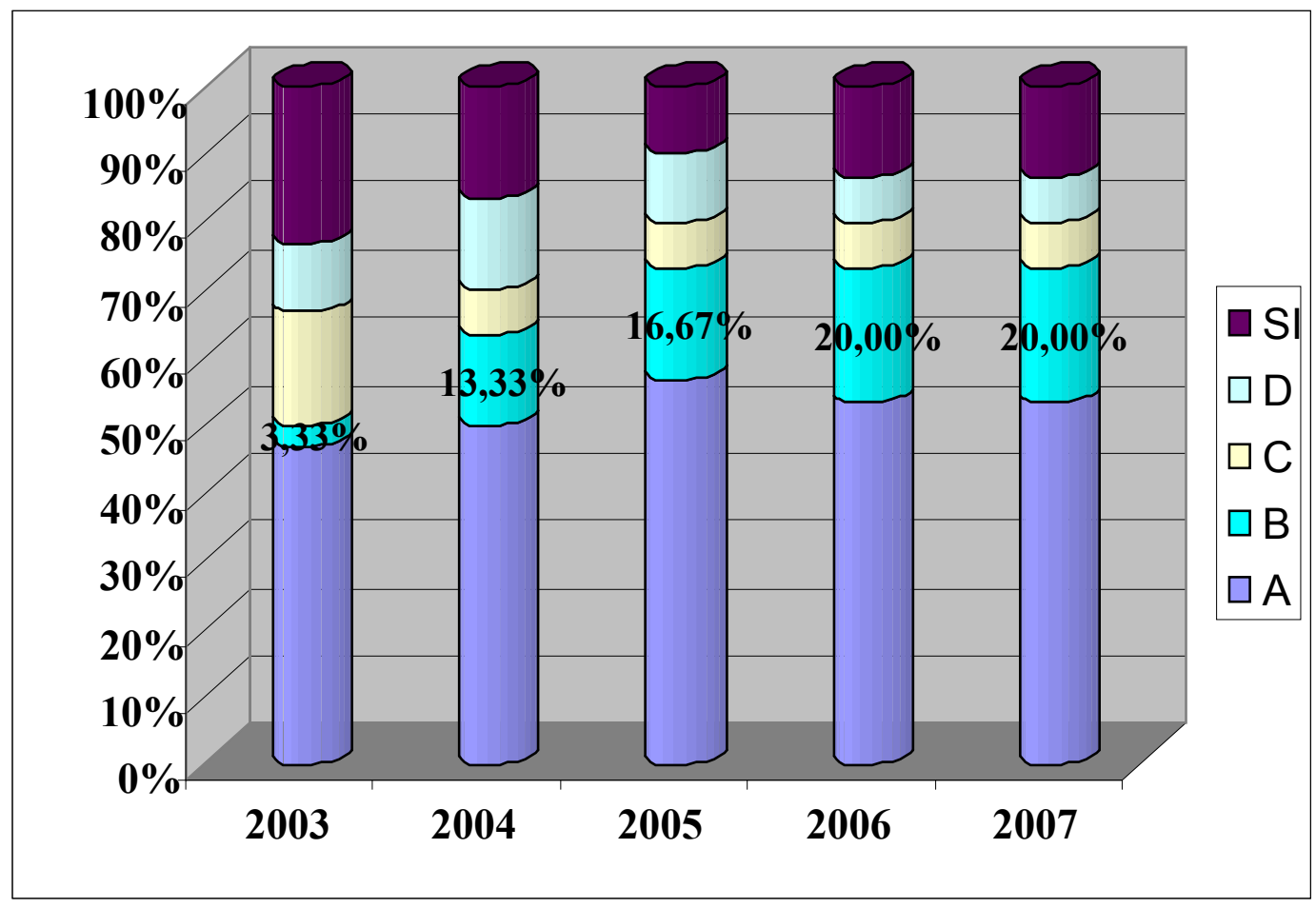

Gráfico 4 - Formas de contabilização dos incentivos fiscais (2003-2007) 
O Quadro 18 mostra, de forma sintética, a Demonstração de Resultado do Exercício, para o ano de 2007, de uma empresa industrial instalada na Zona Franca de Manaus, que contabiliza o incentivo fiscal relativo ao ICMS, na visão deste trabalho, de forma incorreta.

Quadro 18 - Demonstração de resultado do exercício de acordo com a forma de contabilização "A" - 31/12/2007

\begin{tabular}{|l|r|}
\hline RECEITA OPERACIONAL BRUTA & $\mathbf{1 0 0 , 0 0 \%}$ \\
\hline Impostos, Devoluções e Abatimentos & $\mathbf{- 2 0 , 7 5 \%}$ \\
\hline RECEITA OPERACIONAL LÍQUIDA & $\mathbf{7 9 , 2 5 \%}$ \\
\hline Custo dos Produtos Vendidos & $-61,45 \%$ \\
\hline LUCRO BRUTO & $\mathbf{1 7 , 8 0 \%}$ \\
\hline DESPESAS OPERACIONAIS & $-7,09 \%$ \\
\hline Com Vendas & $-6,66 \%$ \\
$\quad$ Gerais e Administrativas & $-0,04 \%$ \\
$\quad$ Receitas Financeiras & $2,76 \%$ \\
$\quad \begin{array}{l}\text { Despesas Financeiras } \\
\text { Impostos e Taxas Diversas }\end{array}$ & $-2,96 \%$ \\
Outras Despesas Líquidas & $-0,16 \%$ \\
\hline LUCRO OPERACIONAL & $-0,03 \%$ \\
\hline RESULTADO NÃO OPERACIONAL & $\mathbf{1 0 , 7 1 \%}$ \\
\hline LUCRO ANTES DO IMPOSTO DE RENDA & $-0,02 \%$ \\
\hline $\begin{array}{l}\text { Imposto de Renda } \\
\text { Contribuição Social }\end{array}$ & $\mathbf{1 0 , 6 9 \%}$ \\
\hline LUCRO LÍQUIDO DO EXERCÍCIO & $\mathbf{- 2 , 9 4 \%}$ \\
\hline $\begin{array}{l}\text { Notas explicativas extraída das demonstrações contábeis publicadas: } \\
\text { 1. Contexto Operacional: } \\
\text { Crédito estímulo de 55\% para fornos de micro-ondas e 100\% para aparelhos condicionadores de ar } \\
\text { tipo janela ou parede, unidade condensadora para condicionador de ar split system e condicionador } \\
\text { de ar com mais de um corpo split system, sobre o valor apurado a título do imposto sobre circulação } \\
\text { de mercadorias e serviços - ICMS, até 5 de outubro de 2023. }\end{array}$ \\
\hline
\end{tabular}

Ao analisar a forma de contabilização dessa empresa, verifica-se que 20,75\% das suas receitas operacionais brutas correspondem aos tributos indiretos, devoluções e abatimentos e que, em nenhum momento, sua Demonstração de Resultado do Exercício considerou o valor do incentivo fiscal do ICMS como "Outras receitas operacionais". Na Demonstração de Mutações do Patrimônio Líquido, observa-se a constituição de Reserva de Capital Subvenção para Investimento, decorrente do crédito estímulo do ICMS, no valor de R\$ 23.086 mil. O Quadro 19, a seguir, mostra a forma de contabilização desses incentivos pela empresa. 
Quadro 19 - Esquema real de contabilização dos incentivos fiscais do ICMS na empresa que contabiliza da forma " $A$ "

\begin{tabular}{|l|c|c|}
\hline & Débito & Crédito \\
\hline No mês de competência & & \\
\hline \multicolumn{1}{|c|}{ ICMS faturado nas Vendas (1) } & 100 & \\
\hline a ICMS a recolher & & 100 \\
\hline No recolhimento do ICMS & & \\
\hline a) pela parcela a ser recolhida do imposto & & \\
\hline ICMS a recolher & 60 & \\
\hline a Caixa ou Bancos & & \\
\hline b) pelo valor do incentivo & & \\
\hline ICMS a recolher & $40^{*}$ & \\
\hline a Reserva de Capital - Subvenção para Investimento & & $40^{*}$ \\
\hline
\end{tabular}

Obs.: ${ }^{(1)}$ A empresa não evidencia o valor do ICMS sobre vendas.

* No caso real representa R\$23.086 mil.

O Quadro 20 mostra, de forma sintética, a Demonstração de Resultado do Exercício, para o ano de 2007, de uma empresa industrial instalada na Zona Franca de Manaus, que contabiliza o incentivo fiscal relativo ao ICMS, na visão deste trabalho, de forma correta.

Quadro 20 - Demonstração de resultado do exercício de acordo com a forma de contabilização "B" - 31/12/2007

\begin{tabular}{|c|c|}
\hline RECEITA OPERACIONAL BRUTA & $100,00 \%$ \\
\hline Impostos, Devoluções e Abatimentos & $-16,20 \%$ \\
\hline RECEITA OPERACIONAL LÍQUIDA & $83,80 \%$ \\
\hline Custo dos Produtos Vendidos & $-50,77 \%$ \\
\hline LUCRO OPERACIONAL BRUTO & $33,02 \%$ \\
\hline RECEITAS (DESPESAS) OPERACIONAIS & $-21,06 \%$ \\
\hline $\begin{array}{l}\text { Despesas de Vendas } \\
\text { Despesas Administrativas } \\
\text { Honorários da Administração } \\
\text { Receitas Financeiras Líquidas } \\
\text { Resultado de Equivalência Patrimonial } \\
\text { Outras Receitas (despesas) Operacionais líquidas }\end{array}$ & $\begin{array}{l}-24,13 \\
-2,19 \\
-0,21 \\
4,44 \\
5,77 \\
-4,73 \\
\end{array}$ \\
\hline RESULTADO OPERACIONAL & $11,96 \%$ \\
\hline RESULTADO NÃO OPERACIONAL & $-0,80 \%$ \\
\hline LUCRO ANTES DO IMPOSTO DE RENDA & $11,16 \%$ \\
\hline Imposto de Renda e Contribuição social & $-1,08 \%$ \\
\hline LUCRO LÍQUIDO DO EXERCÍCIO & $10,08 \%$ \\
\hline $\begin{array}{l}\text { Notas explicativas extraída das demonstrações contábeis publicadas: } \\
\text { 1. Contexto Operacional: } \\
\text { Benefícios Fiscais: A Companhia obteve incentivo fiscal de crédito estí } \\
\text { sobre as saídas de produtos industrializados até o ano de } 2.013 \text {. A conc } \\
\text { Conselho de Desenvolvimento do Estado do Amazonas - CODAM. Cona } \\
\text { decorrente de redução na alíquota, é registrado como dedução dos imp } \\
\text { vendas. }\end{array}$ & $\begin{array}{l}\text { mulo de ICMS incidente } \\
\text { cessão foi aprovada pelo } \\
\text { Esse crédito estímulo, } \\
\text { ostos incidentes sobre as }\end{array}$ \\
\hline
\end{tabular}


A forma de contabilização do crédito estímulo do ICMS faz com que, apenas, a parcela de $16,20 \%$ das suas receitas operacionais brutas seja relacionada aos tributos indiretos, devoluções e abatimentos e que, em nenhum momento, sua Demonstração de Resultado do Exercício considerou o valor do incentivo fiscal do ICMS como "Outras receitas operacionais". Na Demonstração de Mutações do Patrimônio Líquido, observa-se que não houve constituição de Reserva de Capital - Subvenção para Investimento, decorrente do crédito estímulo do ICMS. O Quadro 21 mostra a forma de contabilização desses incentivos pela empresa.

Quadro 21 - Esquema real de contabilização dos incentivos fiscais do ICMS na empresa que contabiliza da forma " $B$ "

\begin{tabular}{|l|c|c|}
\hline & Débito & Crédito \\
\hline No mês de competência & & \\
\hline a) pelo ICMS sobre as vendas & & \\
\hline ICMS faturado nas Vendas & 100 & \\
\hline a ICMS a recolher & & 100 \\
\hline b) pelo valor do incentivo & 40 & \\
\hline ICMS a recolher & & 40 \\
\hline a ICMS faturado nas Vendas & & \\
\hline No recolhimento do ICMS & & \\
\hline Pela parcela a ser recolhida do imposto & 60 & \\
\hline ICMS a recolher & & 60 \\
\hline a Caixa ou Bancos & & \\
\hline
\end{tabular}

Obs.: A empresa não evidencia o valor do ICMS sobre vendas e o valor do crédito estímulo

O Quadro 22 mostra, de forma sintética, a Demonstração de Resultado do Exercício, para o ano de 2007, de uma empresa industrial instalada na Zona Franca de Manaus, que contabiliza o incentivo fiscal relativo ao ICMS, na visão deste trabalho, de forma incorreta.

Quadro 22 - Demonstração de resultado do exercício de acordo com a forma de contabilização "C" $\mathrm{C}$ "31/12/2007

\begin{tabular}{|c|r|}
\hline RECEITA BRUTA & $\mathbf{1 0 0 , 0 0 \%}$ \\
\hline Impostos, Devoluções e Abatimentos & $\mathbf{- 2 2 , 7 0 \%}$ \\
\hline RECEITA LÍQUIDA DE VENDAS & $\mathbf{7 7 , 3 0 \%}$ \\
\hline Custo dos Produtos Vendidos & $-46,78 \%$ \\
\hline LUCRO BRUTO & $\mathbf{3 0 , 5 2 \%}$ \\
\hline DESPESAS OPERACIONAIS & $-21,99 \%$ \\
\hline Vendas, Marketing e Distribuição & $-13,20 \%$ \\
Administrativas & $-5,85 \%$ \\
Resultado Financeiro Líquido & $-2,94 \%$ \\
\hline
\end{tabular}


continuação

\begin{tabular}{|l|r|}
\hline OUTRAS RECEITAS E DESPESAS OPERACIONAIS & $2,41 \%$ \\
\hline Equivalência Patrimonial & $0,46 \%$ \\
Créditos Tributários & $\mathbf{1 , 9 5 \%}$ \\
\hline RESULTADO OPERACIONAL & $\mathbf{1 0 , 9 4 \%}$ \\
\hline RESULTADO NÃO OPERACIONAL & $-0,23 \%$ \\
\hline LUCRO ANTES DO IMPOSTO DE RENDA & $\mathbf{1 0 , 7 1 \%}$ \\
\hline Imposto de Renda e Contribuição Social & $\mathbf{- 2 , 2 9 \%}$ \\
Imposto de Renda Diferido & $-0,12 \%$ \\
\hline LUCRO LÍQUIDO DO EXERCíCIO & $\mathbf{8 , 3 0 \%}$ \\
\hline Notas explicativas extraída das demonstrações contábeis publicadas: \\
A empresa não faz qualquer menção ao contexto operacional e aos incentivos fiscais obtidos. \\
\hline
\end{tabular}

Das receitas operacionais brutas, conforme Quadro 22, 22,70\% correspondem aos tributos indiretos, devoluções e abatimentos e foi considerado como "Outras Receitas Operacionais Créditos Tributários" o valor do incentivo fiscal do ICMS. Na Demonstração de Mutações do Patrimônio Líquido, observa-se a constituição de Reserva de Capital - Incentivos Fiscais, decorrente do crédito estímulo do ICMS, como destinação do Lucro Líquido do Exercício. O Quadro 23 mostra a forma de contabilização desses incentivos pela empresa.

Quadro 23 - Esquema real de contabilização dos incentivos fiscais do ICMS na empresa que contabiliza da forma " $\mathrm{C}$ "

\begin{tabular}{|l|c|c|}
\hline \multicolumn{1}{|l|}{} & Débito & Crédito \\
\hline No mês de competência & & \\
\hline ICMS faturado nas Vendas & 100 & \\
\hline a ICMS a recolher & & 100 \\
\hline No recolhimento do ICMS & & \\
\hline a) pela parcela a ser recolhida do imposto & & \\
\hline ICMS a recolher & 60 & \\
\hline a Caixa ou Bancos & & 60 \\
\hline b) pelo valor do incentivo & & \\
\hline ICMS a recolher & 40 & \\
\hline a Outras Receitas Operacionais - Créditos Tributários & & 40 \\
\hline c) pela constituição da reserva & & \\
\hline Lucro Líquido do Exercício & 40 & \\
\hline a Reserva de Capital - Incentivos Fiscais & & \\
\hline
\end{tabular}

Os Quadros 18, 20 e 22 representam as demonstrações de resultados reais publicadas, em termos percentuais, de três empresas que contabilizam os incentivos fiscais relativos ao ICMS de formas diferentes. 
Assim, a análise realizada sobre a forma de contabilização dos incentivos fiscais relativos ao ICMS, concedidos pelo modelo industrial Zona Franca de Manaus, permite identificar as diversas formas de contabilização, de acordo com o Quadro 17, e chegar à conclusão de que, apenas, $20 \%$ das indústrias, instaladas naquela região incentivada, contabilizam esses incentivos de forma correta contra $66,67 \%$ que contabilizam de forma incorreta.

\subsection{Criação de riqueza pela Zona Franca de Manaus}

Com relação à criação de riqueza, foram realizados testes estatísticos pela técnica de regressão linear simples e pelo teste de média, com vistas a testar a seguinte hipótese auxiliar:

\section{HA2: As empresas industriais, instaladas na Zona Franca de Manaus, beneficiadas com incentivos fiscais, que elaboram ou publicam a Demonstração de Valor Adicionado, criam mais riqueza do que as empresas industriais do mesmo setor ou similares instaladas em outras regiões do país.}

A amostra foi desenvolvida a partir do banco de dados da FIPECAFI, que é utilizado para a elaboração da Edição Anual da Revista Exame Melhores e Maiores empresas, no período de 2003 a 2007, perfazendo o total de 73 observações para as empresas industriais instaladas na ZFM. Essas 73 observações foram, também, separadas em duas subamostras: 19 empresas que contabilizam os incentivos fiscais, o ICMS, de forma correta e 54 que contabilizam de forma errada.

Com relação às empresas industriais instaladas fora da ZFM, foram selecionados três grupos: autoindústria, no qual foram excluídas as empresas que possuíam um valor negativo de riqueza distribuído aos governos e empresas cujos processos produtivos se diferenciavam, sobremaneira, dos da ZFM, como é o caso da Embraer, restando 13 observações. Os setores de bens de consumo, indústria digital e eletroeletrônica foram agrupados em um só, perfazendo o total de 20 observações. E, por fim, o grupo das empresas pares com 73 observações.

Para apresentar a relação entre faturamento e valor adicionado, neste estudo, aplicou-se a técnica de regressão OLS (Ordinary Least Square ou Mínimos Quadrados Ordinários) com 
procedimento de White para correção de problemas de heterocedasticidade, de acordo com Wooldridge $(2002,2006)$ e Kennedy (2006).

Com o objetivo de reduzir problemas de heterocedasticidade, ou seja, retirar o efeito tamanho das firmas das amostras, aplicaram-se duas formas de escalonamento das variáveis: uma, na qual o valor do faturamento e do valor adicionado foram escalonados pelo valor da riqueza distribuída aos empregados e outra pelo valor da riqueza distribuída aos governos. (KENNEDY, 2006).

Dessa forma, as regressões foram separadas em 04 partes para observar o comportamento da amostra:

1. Verificar o impacto do faturamento sobre o valor adicionado das empresas da ZFM;

2. Verificar o impacto do faturamento das empresas que fazem a contabilização correta na ZFM comparadamente com as que contabilizam de forma errada;

3. Comparar as empresas pertencentes aos setores de autoindústria, bens de consumo, indústria digital e eletroeletrônica, instaladas fora da ZFM, com as empresas industriais da ZFM;

4. Comparar as empresas "pares" com as empresas industriais instaladas na ZFM.

Utilizou-se, também, uma variável dummy para as empresas industriais instaladas na ZFM que contabilizam os incentivos fiscais de forma errada, mantendo-se, assim, as empresas que contabilizam os incentivos de forma correta como a base dos modelos econométricos, ou seja, as constantes $\left(\beta_{0}\right)$ das regressões refletem os efeitos das empresas que contabilizam os incentivos de forma correta.

Dessa forma, a Tabela 25 apresenta as estatísticas descritivas da amostra relativa às 73 empresas industriais instaladas na ZFM. Verifica-se que o valor adicionado é, em média, aproximadamente, $31 \%$ do faturamento, conforme seus montantes de U\$ 97.345 mil e U\$ 313.211 mil, respectivamente.

Na sequência, na Tabela 25, apresentam-se o número de observações, o valor adicionado e o faturamento divididos pelo valor de riqueza distribuída aos empregados e aos governos. Destaque-se que o valor adicionado escalonado pela riqueza distribuída aos empregados 
representa 30,28\% do faturamento escalonado, também, por essa mesma riqueza. Quando o valor adicionado é escalonado pela riqueza distribuída aos governos, representa $28,62 \%$ do faturamento.

Tabela 25 - Estatísticas descritivas da amostra

\begin{tabular}{l|c|r|r|r|r}
\hline \multicolumn{7}{c|}{ Variáveis } & Obs. & Média & $\begin{array}{c}\text { Desvio- } \\
\text { Padrão }\end{array}$ & Mínimo & Máximo \\
\hline \multicolumn{7}{c}{ Variáveis da amostra em valores nominais } \\
\hline Valor Adicionado & 73 & 97.345 & 101.296 & 7.510 & 372.073 \\
\hline Pessoal & 73 & 17.132 & 14.270 & 1.120 & 53.830 \\
Governo & 73 & 53.007 & 52.888 & 1.662 & 176.160 \\
\hline Faturamento & 73 & 313.211 & 307.436 & 27.951 & 1.131 .842 \\
\hline \multicolumn{1}{c}{ Variáveis da amostra escalonada pelo valor dos empregados e governos } \\
\hline VadPessoal & 73 & 6,9855 & 10,4353 & 1,2874 & 73,2125 \\
\hline VdaGoverno & 73 & 2,2876 & 1,3473 & 0,8035 & 8,8008 \\
\hline FatPessoal & 73 & 23,0695 & 32,9184 & 4,4500 & 238,6187 \\
\hline FatGoverno & 73 & 7,9917 & 5,9091 & 3,4537 & 43,3665 \\
\hline
\end{tabular}

Obs.: VadPessoal $=$ Valor adicionado dividido por Pessoal; VadGoverno $=$ Valor adicionado dividido por Governo; Fatpessoal = Faturamento dividido por Pessoal e Fatgoverno $=$ Faturamento dividido por Governo

Foi realizado o teste de correlação de Spearman que mostra que as variáveis são, altamente, correlacionadas positivamente em 94,6\%, com probabilidade de 0,000 , logo são dependentes. À medida que uma aumenta, a outra acompanha a mesma direção. Segundo Stevenson (1981, p. 342), "a correlação mede a força, ou grau, de relacionamento entre duas variáveis".

Tabela 26 - Regressões das empresas da Zona Franca de Manaus

\begin{tabular}{|c|c|c|c|c|c|}
\hline \multicolumn{6}{|c|}{$\operatorname{Vad}_{i}=\beta_{0}+\beta_{1} F a t_{i}+\varepsilon_{i}$} \\
\hline $\begin{array}{c}\text { Variáveis / } \\
\text { Modelos }\end{array}$ & $\begin{array}{l}\text { Modelo } \\
\text { (1) }\end{array}$ & $\begin{array}{c}\text { Modelo } \\
\text { (2) }\end{array}$ & $\begin{array}{c}\text { Modelo } \\
\text { (3) }\end{array}$ & $\begin{array}{c}\text { Modelo } \\
\text { (4) }\end{array}$ & $\begin{array}{c}\text { Modelo } \\
\text { (5) }\end{array}$ \\
\hline $\begin{array}{c}\text { Intercepto } \\
\text { erro } \\
\mathbf{t} \\
\mathbf{p}\end{array}$ & $\begin{array}{c}-372,2808 \\
(4065,221) \\
(-0,09) \\
(0,927\end{array}$ & $\begin{array}{l}-0,1851 \\
(0,189) \\
(-0,96) \\
(0,341)\end{array}$ & $\begin{array}{c}0,7194 \\
(0,257) \\
(2,80) \\
(0,007)\end{array}$ & $\begin{array}{c}0,8807 \\
(0,515) \\
(1,71) \\
(0,091)\end{array}$ & $\begin{array}{l}-1,5401 \\
(0,570) \\
(-2,70) \\
(0,009)\end{array}$ \\
\hline $\begin{array}{c}\text { Fat } \\
\text { erro } \\
\mathbf{t} \\
\mathbf{p}\end{array}$ & $\begin{array}{l}0,3120 \\
(0,021) \\
(14,90) \\
(0,000)\end{array}$ & & & & \\
\hline $\begin{array}{c}\text { FatPes } \\
\text { Erro } \\
\mathbf{t} \\
\mathbf{p}\end{array}$ & & $\begin{array}{l}0,3107 \\
(0,009) \\
(33,52) \\
(0,000)\end{array}$ & & $\begin{array}{l}0,3116 \\
(0,009) \\
(34,15) \\
(0,000)\end{array}$ & $\begin{array}{l}0,4285 \\
(0,026) \\
(16,67) \\
(0,000)\end{array}$ \\
\hline $\begin{array}{c}\text { FatGov } \\
\text { Erro } \\
\text { t } \\
\text { p }\end{array}$ & & & $\begin{array}{c}0,1962 \\
(0,037) \\
(5,35) \\
(0,000)\end{array}$ & & \\
\hline
\end{tabular}




\begin{tabular}{|c|c|c|c|c|c|}
\hline $\begin{array}{c}\text { Cont } \\
\text { erro } \\
\mathbf{t} \\
\mathbf{p} \\
\text { VIF }\end{array}$ & & & & $\begin{array}{c}-1,462375 \\
(0,592) \\
(-2,47) \\
(0,016)\end{array}$ & $\begin{array}{c}1,1171 \\
(0,612) \\
(1,83) \\
(0,072)^{*} \\
2,55\end{array}$ \\
\hline $\begin{array}{c}\text { DContFatPes } \\
\text { erro } \\
\text { t } \\
\text { p }\end{array}$ & & & & & $\begin{array}{c}-0,1236 \\
(0,028) \\
(-4,48) \\
(0,000)\end{array}$ \\
\hline VIF & 1,000 & 1,000 & 1,000 & 1,000 & 20,66 \\
\hline $\mathbf{R}^{2}$ & 0,8966 & 0,9604 & 0,7407 & 0,9643 & 0,9720 \\
\hline $\mathbf{F}$ & 221,92 & 1123,35 & 28,66 & 583,32 & 428,78 \\
\hline Prob $>$ F & 0,000 & 0,000 & 0,000 & 0,000 & 0,000 \\
\hline N. Observações & 73 & 73 & 73 & 73 & 73 \\
\hline
\end{tabular}

Obs.: Na 1a. Linha estão os coeficientes das regressões. Entre parênteses, na 2a. linha os erros; Na 3a. linha as estatísticas t e na 4a. linha as probabilidades p. * indica significante ao nível de 10\%; os demais, com exceção dos interceptos, significante ao nível de 5\%.

(1) Modelo de regressão do Valor Adicionado em função do Faturamento, em valores absolutos;

(2) Modelo de regressão do Valor Adicionado em função do Faturamento, com as variáveis valor adicionado e faturamento escalonadas pelo valor de pessoal obtido na DVA de cada empresa;

(3) Modelo de regressão do Valor Adicionado em função do Faturamento, com as variáveis valor adicionado e faturamento escalonadas pelo valor de governos obtido na DVA de cada empresa;

(4) Modelo de regressão do Valor Adicionado em função do Faturamento, com as variáveis valor adicionado e faturamento escalonadas pelo valor de pessoal obtido na DVA de cada empresa e Dummy para as empresas da Zona Franca de Manaus que contabilizam os incentivos de forma errada;

(5) Modelo de regressão do Valor Adicionado em função do Faturamento, com as variáveis valor adicionado e faturamento escalonadas pelo valor de pessoal obtido na DVA de cada empresa e Dummy interativa para as empresas da Zona Franca de Manaus que contabilizam os incentivos de forma errada.

Por meio da Tabela 26, observa-se que as regressões mostram a relevância das variáveis em relação ao valor adicionado. Todos os modelos apresentaram nível de confiança de 95\%, com exceção do modelo 5, no qual a variável (Cont), considerada como dummy interativa para as empresas da ZFM que contabilizam os incentivos fiscais de forma errada, cujo nível de confiança foi de $90 \%(0,072)$.

As regressões mostram a relevância do faturamento, tanto em termos absolutos do modelo 1 , como escalonado pela riqueza distribuída aos empregados, nos modelos 2, 4 e 5, quando comparado ao faturamento escalonado pela riqueza distribuída aos governos, no modelo 2. Por exemplo, o coeficiente do faturamento (Fat) foi de 0,3120 na regressão do modelo 1 e o coeficiente do faturamento escalonado pela riqueza distribuída aos empregados foi de 0,3107 na regressão do modelo 2 , enquanto o do modelo 3 , escalonado pelo riqueza distribuída aos governos, foi de 0,1962. Embora sejam todos significantes, existe uma maior inclinação para os demais modelos ao invés do modelo 2. Esses resultados indicam maior importância dos coeficientes dos modelos 1, 2, 4 e 5 . 
Ao analisar o poder preditivo do regressor $\left(\mathrm{R}^{2}\right)$, observa-se que a regressão do modelo 3 é a que apresenta o mais baixo poder preditivo $(0,7407)$, portanto, mais distante de 1,00 , ou seja, é o modelo que apresenta a maior dispersão em torno da reta de regressão.

Diante dos modelos apresentados na Tabela 26, no modelo 2, as variáveis valor adicionado e faturamento foram escalonadas pelo valor de pessoal. Assim, o modelo 2 mostra que a criação de riqueza pelo modelo industrial Zona Franca de Manaus é de 31,07\% do seu faturamento.

Da mesma maneira que foram calculadas as regressões lineares para as Empresas da ZFM, foi, igualmente, realizada para o grupo de Empresas Pares separadamente. Inicialmente, apresentam-se as estatísticas descritivas para esse grupo, de acordo com a Tabela 27. Observe-se que o valor adicionado é, em média, $45 \%$.

Tabela 27 - Estatísticas descritivas da amostra de empresas pares

\begin{tabular}{l|c|r|r|r|r}
\hline \multicolumn{1}{c|}{ Variáveis } & Obs. & Média & $\begin{array}{c}\text { Desvio- } \\
\text { Padrão }\end{array}$ & Mínimo & Máximo \\
\hline \multicolumn{5}{c}{ Variáveis da amostra em valores nominais } \\
\hline Valor Adicionado & 73 & 111.076 & 126.520 & 13.534 & 779.113 \\
Pessoal & 73 & 35.108 & 34.362 & 1.738 & 136.610 \\
Faturamento & 73 & 244.440 & 225.686 & 30.726 & 1.232 .783 \\
\multicolumn{5}{c}{ Variáveis da amostra escalonada pelo valor dos empregados e governos } \\
\hline VadPessoal & 73 & 4,4244 & 6,6209 & 1,1790 & 55,0104 \\
\hline
\end{tabular}

Obs.: VadPessoal = Valor adicionado dividido por Pessoal e FatPessoal = Faturamento dividido por Pessoal.

Foi realizado o teste de correlação de Spearman que mostra que as variáveis são, altamente, correlacionadas positivamente em $82,06 \%$, com probabilidade de 0,000 , logo, dependentes. À medida que uma aumenta, a outra acompanha na mesma direção.

A Tabela 28, a seguir, apresenta a regressão linear calculada para o grupo de Empresas Pares. A regressão mostra a relevância do faturamento escalonado pela riqueza distribuída aos empregados. Como se observa, o coeficiente do faturamento (Fat) foi de 0,5436, com um poder explicativo $\left(\mathrm{R}^{2}\right)$ de $87,82 \%$. 
Tabela 28 - Regressões das empresas pares

$\operatorname{Vad}_{i}=\beta_{0}+\beta_{1} F_{a t}+\varepsilon_{i}$

\begin{tabular}{c|c}
\hline Variáveis / Modelos & VadPesFatPes $^{(1)}$ \\
\hline Intercepto & $-1,0973$ \\
Erro padrão & $(0,679)$ \\
$\mathbf{t}$ & $(-1,62)$ \\
$\mathbf{p}$ & $(0,110)$ \\
FatPes & $0,5436^{*}$ \\
erro & $(0,083)$ \\
$\mathbf{t}$ & $(6,52)$ \\
$\mathbf{R}^{\mathbf{2}}$ & 0,8782 \\
$\mathbf{F}$ & 42,65 \\
Prob>F & 0,000 \\
VIF & 1,000 \\
N. Observações & 73 \\
\hline Obs. Na 1a. linha estão os coeficientes das reoressões. Entre parênteses, na
\end{tabular}

2a. linha, os erros; Na 3a. linha, as estatísticas t. * indicam significante ao nível de $1 \%$.

(1) Modelo de regressão do Valor Adicionado em função do Faturamento, com as variáveis valor adicionado e faturamento escalonadas pelo valor de pessoal obtido na DVA de cada empresa.

Após calcular as regressões para os dois grupos (Empresas ZFM e Empresas Pares), separadamente, optou-se por calcular, numa mesma amostra, os dois grupos em conjunto. A Tabela 29 apresenta as estatísticas descritivas desse novo grupo, com 146 observações. Destaque-se que o valor adicionado representa, em média, $37 \%$ do faturamento, com um montante de US\$ 104.210.

Tabela 29 - Estatísticas descritivas da amostra das empresas da ZFM e empresas pares

\begin{tabular}{l|c|r|r|r|r}
\hline \multicolumn{1}{c}{ Variáveis } & Obs. & Média & \multicolumn{1}{c|}{$\begin{array}{c}\text { Desvio- } \\
\text { Padrão }\end{array}$} & Mínimo & Máximo \\
\hline \multicolumn{5}{c}{ Variáveis da amostra em valores nominais } \\
\hline Valor Adicionado & 146 & 104.210 & 114.416 & 7.510 & 779.113 \\
Pessoal & 146 & 26.120 & 27.726 & 1.120 & 136.610 \\
Faturamento & 146 & 278.825 & 270.951 & 27.951 & 1.232 .783 \\
\multicolumn{6}{c}{ Variáveis da amostra escalonada pelo valor dos empregados e governos } \\
VadPessoal & 146 & 5,7050 & 8,8029 & 1,1790 & 73,2125 \\
FatPessoal & 146 & 16,6136 & 25,3915 & 1,3190 & 238,6187 \\
\hline
\end{tabular}

Obs.: VaPessoal $=$ Valor adicionado dividido por Pessoal e FatPessoal $=$ Faturamento dividido por Pessoal.

A Tabela 30, a seguir, apresenta a correlação das variáveis do modelo. Verifica-se que as correlações das variáveis são, estatisticamente, significantes a $1 \%$ e que existe uma correlação adequada entre as variáveis explicativas Faturamento, Pares e DContFatPes com a variável Valor Adicionado. Apenas, a variável Cont seria ao nível confiança de 90\%. 
Tabela 30 - Correlação de Spearman

\begin{tabular}{l|c|c|c|c|c}
\hline \multicolumn{1}{c|}{ Variáveis } & VaPes & FatPes & Cont & Pares & DcontFatPes \\
\hline VadPes & 1,0000 & & & & \\
FatPes & 0,8306 & 1,0000 & & & \\
Cont & $(0,0000)$ & & & & \\
Pares & 0,1340 & 0,3201 & 1,0000 & & \\
& $(0,1069)$ & $(0,0001)$ & & & \\
DContFatPes & $-0,2651$ & $-0,4721$ & $-0,7661$ & 1,0000 & \\
& $(0,0012)$ & $(0,0000)$ & $(0,0000)$ & & \\
\hline & 0,2609 & 0,4476 & 0,9657 & $-0,7398$ & 1,0000 \\
\hline
\end{tabular}

Obs.: Todas as variáveis estão escalonadas pelo valor de pessoal obtido na DVA de cada empresa; $\mathrm{Va}=$ Valor Adicionado; Fat $=$ Faturamento; Cont $=$ Empresas da Zona Franca de Manaus que contabilizam os incentivos fiscais de forma errada; Pares = Empresas pares (grupo de controle) e DContFatPes = Variável Dummy para empresas que contabilizam os incentivos de forma errada.

Os modelos de regressões do valor adicionado em função do faturamento para o grupo de Empresas da ZFM e o de Empresas Pares são apresentados na Tabela 31. Ambos os modelos mostram a relevância do faturamento escalonado pelo valor de pessoal. O coeficiente do faturamento (FatPes) foi de 0,5081 na regressão do modelo 1 e 0,3357 na regressão do modelo 2. Embora os dois modelos sejam significantes ao nível de 5\%, o modelo 1 apresenta uma maior inclinação e um poder explicativo maior, 0,9428 contra 0,8977 do modelo 2 .

Tabela 31 - Regressões empresas ZFM e empresas pares $\operatorname{Vad}_{i}=\beta_{0}+\beta_{1} F_{i t}+\varepsilon_{i}$

\begin{tabular}{c|c|c}
\hline Variáveis / Modelos & Modelo $^{(\mathbf{1})}$ & Modelo $^{(2)}$ \\
\hline Intercepto & $-0,7369$ & $-0,7582$ \\
erro & $(0,550)$ & $(0,603)$ \\
$\mathbf{t}$ & $(-1,34)$ & $(-1,26)$ \\
$\mathbf{p}$ & $(0,183)$ & $(0,211)$ \\
FatPes & 0,5081 & 0,3357 \\
erro & $(0,072)$ & $(0,028)$ \\
$\mathbf{t}$ & $(7,09)$ & $(12,09)$ \\
$\mathbf{p}$ & $(0,000)$ & $(0,000)$ \\
VIF & 6,89 & 1,070 \\
ZFM & $-2,4500$ & \\
erro & $(1,070)$ & \\
$\mathbf{t}$ & $(-2,29)$ & \\
$\mathbf{p}$ & $(0,024)$ & \\
VIF & 2,72 & \\
Cont & 2,7640 & \\
erro & $(1,55637)$ & \\
$\mathbf{t}$ & $(1,78)$ & \\
$\mathbf{p}$ & $(0,078)$ & \\
VIF & 3,76 & \\
& & \\
\hline
\end{tabular}




\begin{tabular}{c|c|c}
\hline \multicolumn{2}{c}{ DContFatPes } & \multicolumn{2}{r}{ continuação } \\
erro & $-0,2032$ & \\
$\mathbf{t}$ & $(0,072)$ & \\
$\mathbf{p}$ & $(-2,81)$ & \\
VIF & $(0,006)$ & 1,7730 \\
Pares & 8,13 & $(0,697)$ \\
erro & & $(2,54)$ \\
$\mathbf{t}$ & & $(0,012)$ \\
$\mathbf{p}$ & & 1,070 \\
VIF & & 0,8977 \\
\hline $\mathbf{R}^{2}$ & 0,9428 & 138,32 \\
$\mathbf{F}$ & 272,87 & 0,000 \\
\hline Prob>F & 0,000 & 146 \\
\hline N. Observações & 146 & \\
\hline
\end{tabular}

Obs.: Na 1a. linha estão os coeficientes das regressões. Entre parênteses, na $2 \mathrm{a}$. linha os erros; na 3a. linha, as estatísticas t e, na 4a. linha, as probabilidades p. * indica significante ao nível de $10 \%$; os demais, com exceção dos interceptos, significante ao nível de $5 \%$.

(1) Modelo com todas as empresas da Zona Franca de Manaus juntas às Empresas Pares

(2) Modelo de regressão do Valor Adicionado em função do Faturamento, com as variáveis valor adicionado e faturamento escalonadas pelo valor de pessoal obtido na DVA de cada empresa com Dummy para as Empresas Pares.

Adicionalmente, com relação à criação de riqueza, foi realizado o teste de média para amostras emparelhadas, no qual se busca descobrir se existe diferença entre a média do valor adicionado do grupo de Empresas da ZFM e a média do valor adicionado do grupo de Empresas Pares. Assim, o teste $t$, paramétrico, para médias emparelhadas procura testar as seguintes hipóteses:

$$
\begin{aligned}
& \mathrm{H}_{0}: \mu_{\text {vad (ZFM - Pares) }}=0 \\
& \mathrm{H}_{1}: \mu_{\mathrm{vad} \text { (ZFM - Pares) }} \neq 0
\end{aligned}
$$

em que:

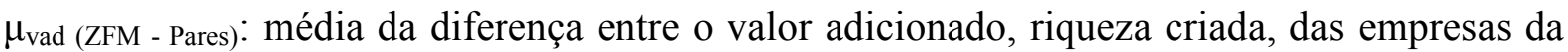
Zona Franca de Manaus em relação às respectivas empresas pares instaladas fora da ZFM.

Para que se possam realizar inferências com base em testes paramétricos, deve-se garantir, pelo Teorema do Limite Central, que a população sob amostragem tenha distribuição normal, uma vez que a amostra é considerada grande ( $>30$ ), de acordo com Stevenson (2001, p. 181) e Maroco (2003, p. 114). 
Logo, para averiguar a validade dos resultados, foi aplicada a estatística KolmogorovSmirnov, que serve para testar se a variável estudada possui ou não distribuição normal e também por ser um dos testes mais indicados para amostras de grande dimensão. (MAROCO, 2003).

Tabela 32 - Teste de normalidade

\begin{tabular}{lccc} 
Variáveis & $\begin{array}{c}\text { Estatística } \\
\text { Kolmogorov-Smirnov }\end{array}$ & Observações & $\begin{array}{c}\text { Nível de } \\
\text { Significância }\end{array}$ \\
\hline Vad_ZFM & 0,140 & 73 & $0,001^{*}$ \\
Pes_ZFM & 0,093 & 73 & 0,195 \\
Gov_ZFM & 0,087 & 73 & 0,200 \\
Acio_ZFM & 0,094 & 73 & 0,181 \\
Vad_PAR & 0,141 & 73 & $0,001 *$ \\
Pes_PAR & 0,092 & 73 & 0,200 \\
Gov_PAR & 0,108 & 73 & $0,033^{* *}$ \\
Acio_PAR & 0,181 & 73 & $0,000 *$ \\
\hline Não Significante; ** Significante a 1\%. & & \\
$\begin{array}{l}\text { Essa tabela apresenta os resultados do teste de normalidade } \\
\text { Smirnov para as variáveis Vad, Pes, Gov e Acio para as empresas da ZFM e } \\
\text { empresas pares. }\end{array}$
\end{tabular}

De acordo com a Tabela 32 as variáveis Vad_ZFM, Vad_PAR e Acio_PAR não possuem distribuições normais. Assim, foi aplicado o teste Wilcoxon, que é uma alternativa não paramétrica ao teste $t$ de amostras emparelhadas, uma vez que não foi atendido o pressuposto da normalidade para essas variáveis.

Segundo Bussab e Morettin (2002, p. 374), "o teste de Wilcoxon é mais eficiente do que o teste $t$ para distribuições que apresentam caudas "mais pesadas" do que a normal". A Tabela 33 mostra que apenas a variável A_ZFM-A_PARES é, estatisticamente, significante ao nível de $5 \%$, uma vez que não houve a rejeição de $\mathrm{H}_{0}$, ou seja, as médias são iguais.

Tabela 33 - Teste de média das amostras emparelhadas

\begin{tabular}{lcc}
\hline \multicolumn{1}{c}{ Variáveis } & Estatística & Nível de Significância \\
\hline Vad_ZFM-Vad_PARES & $-5,599$ & 0,000 \\
P_ZFM-P_PARES & $-3,175$ & 0,001 \\
G_ZFM-G_PARES & $-3,070$ & 0,002 \\
A_ZFM-A_PARES & $-0,706$ & 0,480 \\
\hline
\end{tabular}


Observe-se que o grau de correlação entre as variáveis das amostras emparelhadas foi estatisticamente significante a 1\%. A Tabela 34 mostra os resultados do teste de média do valor adicionado das amostras emparelhadas.

Tabela 34 - Teste de média do valor adicionado de amostras emparelhadas

\begin{tabular}{lccc}
\hline \multicolumn{1}{c}{ Variáveis } & VadZFM & VadPARES & VadZFM - VadPARES \\
\hline Média da amostra & 0,3096 & 0,4508 & $-0,1412$ \\
Desvio padrão da amostra & 0,1040 & 0,1502 & \\
Diferença máxima & & & $-0,0990$ \\
Diferença mínima & & $-0,1833$ \\
Desvio-padrão da diferença & & 0,1808 \\
Estatística t & & $-6,670$ \\
Nível de significância & & 0,000 \\
\hline
\end{tabular}

73 observações para cada amostra e teste t com 72 graus de liberdade

Essa tabela apresenta resultados de teste de amostras emparelhadas que verificou se a diferença entre VadZFM - VadPARES, calculada para cada par de empresas, é, estatisticamente, diferente de zero. VadZFM refere-se ao percentual de valor adicionado estimado criado estimado pelo grupo de empresas da Zona Franca de Manaus. VadPARES refere-se ao percentual de valor adicionado estimado criado pelo grupo de empresas fora da Zona Franca de Manaus.

Para as empresas industriais instaladas na ZFM, a média do valor adicionado é de 30,96\% sobre o faturamento, enquanto para as empresas pares instaladas fora da ZFM é de $45,08 \%$. A diferença resultante foi de $14,12 \%$, que pode ser interpretada como o valor de riqueza criada a mais pelo grupo de empresas pares, conforme disposto na Tabela 34. Logo, obtém-se a seguinte equação:

$$
\left[\operatorname{Vad}_{\mathrm{ZFM}}-\operatorname{Vad}_{\text {Pares }}\right]=-0,1412
$$

Verifica-se que existe diferença entre as médias do valor adicionado e que se mostra, estatisticamente, significante ao nível de $1 \%(0,000)$.

Com os dados reais das Demonstrações de Valor Adicionado das empresas foram elaboradas DVAs consolidadas por grupo de controle. Os resultados apresentados no Quadro 23 foram obtidos a partir dos dados constantes dos Apêndices 8, 9, 10, 11 e 14, que mostram, respectivamente, o percentual de criação de riqueza (Valor Adicionado a distribuir) pelas empresas por meio das suas DVAs consolidadas no período de 2003 a 2007. 
Quadro 24 - Criação de riqueza das DVAs consolidadas (\%)

\begin{tabular}{|l|c|c|c|c|c|}
\hline \multicolumn{1}{|c|}{ Grupo Empresas } & $\mathbf{2 0 0 3}$ & $\mathbf{2 0 0 4}$ & $\mathbf{2 0 0 5}$ & $\mathbf{2 0 0 6}$ & $\mathbf{2 0 0 7}$ \\
\hline Empresas ZFM & 28,70 & 33,71 & 30,78 & 30,27 & 30,95 \\
Empresas ZFM Corretas & 32,86 & 40,00 & 33,93 & 33,62 & 29,19 \\
Empresas ZFM Erradas & 26,58 & 30,81 & 29,36 & 26,83 & 32,41 \\
Setores Fora ZFM * & 34,86 & 31,32 & 50,25 & 52,34 & 53,95 \\
Empresas Pares & 41,37 & 43,91 & 43,82 & 52,11 & 47,37 \\
\hline
\end{tabular}

* Compreende os setores de autoindústria, bens de consumo, indústria digital e eletroeletrônico

Da análise do Quadro 24, conclui-se que:

- $\quad$ os setores fora da ZFM, nos anos de 2005 a 2007, apresentam dispersões, oscilações, em decorrência do número reduzido de empresas e por incluir empresa do setor de fumos no setor de bens de consumo, distorcendo o percentual de criação de riqueza;

- $\quad$ as empresas industriais da ZFM que contabilizam os incentivos fiscais de forma errada evidenciam e divulgam, de maneira equivocada, uma menor taxa de criação de riqueza porque consideram o valor total do ICMS sobre as vendas;

- $\quad$ as empresas industriais da ZFM que contabilizam os incentivos fiscais de forma correta evidenciam e divulgam, de maneira adequada, a criação de riqueza porque contabilizam, na DRE, somente o ICMS efetivamente pago.

Por meio do Gráfico 5, observe-se que as empresas da ZFM criam menos riqueza do que as empresas pares.

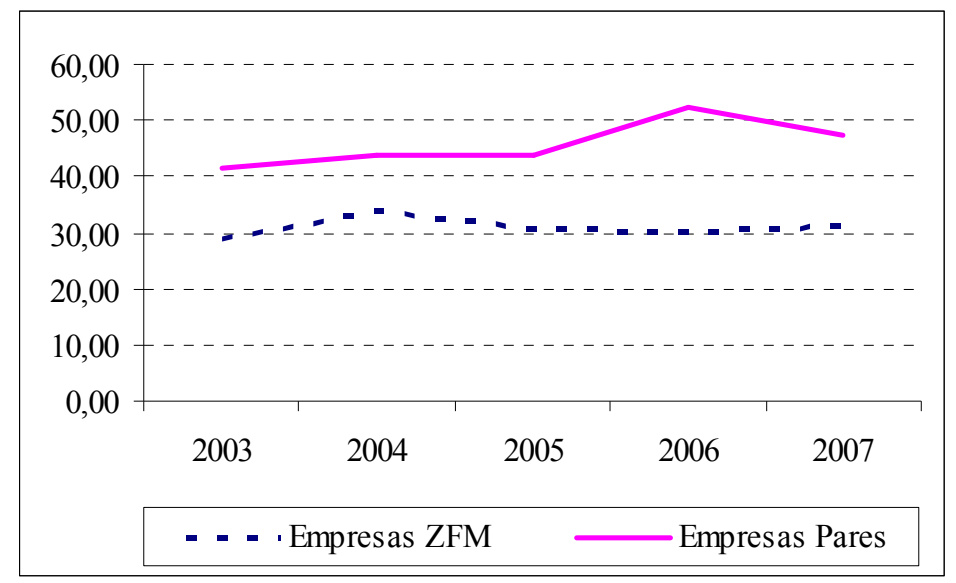

Gráfico 5 - Criação de riqueza (\%) 
Em síntese, atendendo ao objetivo específico proposto de mensurar a criação de riqueza pelas empresas industriais beneficiárias de incentivos fiscais instaladas na Zona Franca de Manaus, tanto pela regressão linear $(31,07 \%$ contra $54,36 \%)$ como pelo teste de média $(30,96 \%$ contra 45,08\%) e pelas DVAs reais consolidadas, rejeita-se a hipótese auxiliar 2, ou seja, as empresas industriais instaladas na ZFM criam menos riqueza do que as empresas industriais dos mesmos setores ou similares instaladas em outras regiões do País.

\subsection{Distribuição de riqueza pela Zona Franca de Manaus}

Com relação à distribuição de riqueza, foram realizados os testes de média para amostras independentes Mann-Whitney, não paramétricos, e o teste t para teste de médias emparelhadas paramétrico. Esses testes foram utilizados para analisar a distribuição da riqueza criada pela empresa, em função do seu faturamento, entre os grupos de pessoal, governos e proprietários, que, no esboço deste trabalho, consideram-se como os principais stakeholders da empresa.

Para essa análise, os grupos de controle foram codificados de acordo com as variáveis do Quadro 16, apresentando os seguintes significados:

- ZFM_T: total de empresas industriais da ZFM incluídas na amostra;

- ZFM_E: total de empresas industriais da ZFM que contabilizam os incentivos fiscais de forma errada;

- ZFM_C: total de empresas industriais da ZFM que contabilizam os incentivos fiscais de forma correta;

- FOR_T: total de empresas dos setores de autoindústria, bens de consumo, indústria digital e eletroeletrônica instaladas fora da ZFM incluídas na amostra;

- FOR_A: total de empresas do setor de autoindústria instalado fora da ZFM;

- FOR_B: total de empresas do setor de bens de consumo, indústria digital e eletroeletrônica instaladas fora da ZFM;

- $\quad$ PARES: total de empresas pares das empresas da ZFM, instaladas fora da ZFM.

Logo, de acordo com a distribuição de riqueza para cada grupo de stakeholder, foi acrescentada uma letra de identificação antes da variável apresentada acima. Assim, 
P_ZFM_T refere-se ao valor adicionado distribuído ao grupo Pessoal pelo total de empresas industriais da ZFM incluídas na amostra; G_FOR_T refere-se ao valor adicionado distribuído ao grupo Governos pelo total de empresas dos setores de autoindústria, bens de consumo, indústria digital e eletroeletrônica, instaladas fora da ZFM, incluídas na amostra; A_PARES refere-se ao valor adicionado distribuído ao grupo de Proprietários das empresas pares instaladas fora da ZFM e, assim, sucessivamente.

\subsubsection{Pessoal}

A análise da distribuição de riqueza para o grupo Pessoal busca testar a hipótese auxiliar 3, assim especificada:

HA3: As empresas industriais, instaladas na Zona Franca de Manaus, beneficiadas com incentivos fiscais, que elaboram ou publicam a Demonstração de Valor Adicionado, distribuem uma parcela maior da riqueza aos empregados do que as empresas industriais do mesmo setor ou similares instaladas em outras regiões do país.

A Tabela 35 mostra o percentual de distribuição do valor adicionado pela empresa para a parte interessada empregados. Foi utilizada a estatística descritiva para calcular a média da amostra das empresas com Demonstração de Valor Adicionada (DVA). No período estudado, verifica-se que, da riqueza distribuída, em média, os empregados recebem $27,28 \%$ do grupo de empresas industriais da ZFM (P_ZFM_T) e 36,31\% do grupo de empresas pares (P_PARES).

Tabela 35 - Estatísticas descritivas para o valor adicionado distribuído a pessoal

\begin{tabular}{l|c|r|r|r|r|r}
\hline Grupo & $\begin{array}{c}\mathbf{N}^{\mathbf{0}} \text { de } \\
\text { observações }\end{array}$ & \multicolumn{1}{c|}{ Média } & Mínimo & Máximo & Mediana & $\begin{array}{c}\text { Desvio- } \\
\text { padrão }\end{array}$ \\
\hline P_ZFM_T & 73 & 0,2728 & 0,0137 & 0,7767 & 0,2596 & 0,1589 \\
P_ZFM_C & 19 & 0,2253 & 0,0437 & 0,4553 & 0,2257 & 0,1211 \\
P_ZFM_E & 54 & 0,2895 & 0,0137 & 0,7767 & 0,2658 & 0,1680 \\
P_FOR_T & 37 & 0,3357 & 0,0948 & 0,6362 & 0,3226 & 0,1279 \\
P_FOR_A & 13 & 0,3640 & 0,2997 & 0,4933 & 0,3449 & 0,0592 \\
P_FOR_B & 24 & 0,3203 & 0,0948 & 0,6362 & 0,2778 & 0,1519 \\
P_PARES & 73 & 0,3631 & 0,0182 & 0,8482 & 0,3423 & 0,1794 \\
\hline
\end{tabular}


Foi aplicado o teste Mann-Whitney por se tratar de um teste para amostras independentes no qual se procura conhecer se a média do valor adicionado distribuído aos empregados pelo grupo de empresas da ZFM (ZFM_T) é igual à média dos demais grupos comparados.

As hipóteses testadas foram:

$$
\begin{aligned}
& \mathrm{H}_{0}: \mu_{\mathrm{P}_{-} \mathrm{ZFM}} \mathrm{T}_{-}=\mu_{\mathrm{P}_{-} \mathrm{FOR}} \mathrm{T} \\
& \mathrm{H}_{1}: \text { Existe diferença entre as médias. }
\end{aligned}
$$

$$
\begin{aligned}
& \mathrm{H}_{0}: \mu_{\mathrm{P}_{-} \mathrm{ZFM}}{ }_{-} \mathrm{T}=\mu_{\mathrm{P}_{-} \mathrm{FOR} \_\mathrm{A}} \\
& \mathrm{H}_{1}: \text { Existe diferença entre as médias. }
\end{aligned}
$$

$\mathrm{H}_{0}: \mu_{\mathrm{P}_{-} \mathrm{ZFM}} \mathrm{T}=\mu_{\mathrm{P}_{-} \mathrm{FOR}} \mathrm{B}$

$\mathrm{H}_{1}$ : Existe diferença entre as médias.

Os resultados do teste não paramétrico aplicado constataram que há diferença significativa entre a média de valor adicionado distribuído ao pessoal do grupo de empresas da ZFM (P_ZFM_T) e os grupos de empresas dos setores fora da ZFM (P_FOR_T) e do grupo de empresas do setor de autoindústria (P_FOR_A) com um nível de nível de significância de 5\%, conforme disposto na Tabela 36.

Tabela 36 - Teste de média do valor adicionado distribuído a pessoal entre o grupo ZFM T e outros grupos

\begin{tabular}{c|l|c|c|c|c|l}
\hline Grupo & $\begin{array}{c}\text { Grupo } \\
\text { Comparação }\end{array}$ & $\begin{array}{c}\mathbf{N}^{\mathbf{0}} \\
\text { observações }\end{array}$ & $\begin{array}{c}\text { Média } \\
\text { amostral }\end{array}$ & $\begin{array}{c}\text { Estatística } \\
\mathbf{Z}\end{array}$ & $\begin{array}{c}\text { Nível de } \\
\text { significância }\end{array}$ & Resultado \\
\hline P_ZFM_T & 73 & 0,2728 & & & \\
& P_FOR_T & 37 & 0,3357 & $-2,534$ & 0,011 & Rejeita H0 \\
& P_FOR_A & 13 & 0,3640 & $-2,682$ & 0,007 & Rejeita H0 \\
& P_FOR_B & 24 & 0,3203 & $-1,488$ & 0,137 & Não Rejeita H0 \\
\hline
\end{tabular}

Essa tabela apresenta resultados de teste de amostras independentes que verificaram se a média entre P_ZFM_T e P_FOR_T, P_FOR_A e P_FOR_B é, estatisticamente, diferente de zero. P_ZFM_T referese ao percentual de valor adicionado estimado distribuído aos empregados pelo grupo total de empresas da Zona Franca de Manaus. P_FOR_T refere-se ao percentual de valor adicionado estimado distribuído aos empregados pelo grupo total de empresas fora da Zona Franca de Manaus. P_FOR_A refere-se ao percentual de valor adicionado estimado distribuído aos empregados pelas empresas do setor autoindústrias fora da Zona Franca de Manaus. P_FOR_B refere-se ao percentual de valor adicionado estimado distribuído aos empregados pelas empresas do setor bens de consumo, eletroeletrônico e indústria digital fora da Zona Franca de Manaus. 
De igual forma, foi aplicado o teste Mann-Whitney para amostras independentes para testar se a média do valor adicionado distribuído aos empregados pelo grupo de empresas da ZFM que contabilizam os incentivos fiscais de forma correta $\left(Z F M \_C\right)$ é igual à média dos demais grupos comparados.

As hipóteses testadas foram:

$$
\begin{aligned}
& \mathrm{H}_{0}: \mu_{\mathrm{P}} \text { ZFM_C }=\mu_{\mathrm{P} Z \mathrm{ZFM}} \mathrm{E} \\
& \mathrm{H}_{1} \text { : Existe diferença entre as médias. } \\
& \mathrm{H}_{0}: \mu_{\text {P_ZFM_C }}=\mu_{\text {P_FOR_T }} \\
& \mathrm{H}_{1} \text { : Existe diferença entre as médias. } \\
& \mathrm{H}_{0}: \mu_{\mathrm{P}_{-} \mathrm{ZFM}} \mathrm{C}=\mu_{\mathrm{P}_{-} \text {FOR_A }} \\
& \mathrm{H}_{1} \text { : Existe diferença entre as médias. } \\
& \mathrm{H}_{0}: \mu_{\mathrm{P}_{-} \mathrm{ZFM}} \mathrm{C}=\mu_{\mathrm{P}_{-} \text {FOR_B }} \\
& \mathrm{H}_{1} \text { : Existe diferença entre as médias. }
\end{aligned}
$$

Os resultados do teste não paramétrico aplicado constataram que há diferença significativa entre a média de valor adicionado distribuídos ao pessoal do grupo de empresas da ZFM (P_ZFM_C) e os grupos de empresas dos setores fora da ZFM (P_FOR_T), grupo de empresas fora da ZFM do setor de autoindústria (P_FOR_A) e do grupo de empresas dos setores de bens de consumo, indústria digital e eletroeletrônica fora da ZFM (P_FOR_B) com um nível de nível de significância de 5\%, conforme disposto na Tabela 37, embora o resultado apresente uma significância muito próxima de 5\% para o grupo de empresas P_FOR_B.

Por outro lado, não há evidências que possam levar a rejeitar a $H_{0}$ quando comparada com o grupo de empresas industriais instaladas na ZFM que contabilizam os incentivos fiscais de forma incorreta (P_ZFM_E). 
Tabela 37 - Teste de média do valor adicionado distribuído a pessoal entre o grupo ZFM_C e outros grupos

\begin{tabular}{c|l|c|c|c|c|l}
\hline Grupo & $\begin{array}{c}\text { Grupo } \\
\text { Comparação }\end{array}$ & $\begin{array}{c}\mathbf{N}^{\mathbf{0}} \\
\text { observações }\end{array}$ & $\begin{array}{c}\text { Média } \\
\text { amostral }\end{array}$ & $\begin{array}{c}\text { Estatística } \\
\mathbf{Z}\end{array}$ & $\begin{array}{c}\text { Nível de } \\
\text { significância }\end{array}$ & \multicolumn{1}{|c}{ Resultado } \\
\hline P_ZFM_C & & 19 & 0,2253 & & & \\
& P_ZFM_E & 54 & 0,2895 & $-1,169$ & 0,242 & Não Rejeita H0 \\
& P_FOR_T & 37 & 0,3357 & $-3,037$ & 0,002 & Rejeita H0 \\
& P_FOR_A & 13 & 0,3640 & $-3,549$ & 0,000 & Rejeita H0 \\
& P_FOR_B & 24 & 0,3203 & $-2,030$ & 0,042 & Rejeita H0 \\
\hline
\end{tabular}

Essa tabela apresenta resultados de teste de amostras independentes que verificaram se a média entre P_ZFM_C e P_FOR_T, P_FOR_A e P_FOR_B é, estatisticamente, diferente de zero. P_ZFM_C refere-se ao percentual de valor adicionado estimado distribuído aos empregados pelo grupo total de empresas da Zona Franca de Manaus que contabilizam os incentivos fiscais de forma correta. P_FOR_T refere-se ao percentual de valor adicionado estimado distribuído aos empregados pelo grupo total de empresas fora da Zona Franca de Manaus. P_FOR_A refere-se ao percentual de valor adicionado estimado distribuído aos empregados pelas empresas do setor autoindústrias fora da Zona Franca de Manaus. P_FOR_B refere-se ao percentual de valor adicionado estimado distribuído aos empregados pelas empresas do setor bens de consumo, eletroeletrônico e indústria digital fora da Zona Franca de Manaus.

Foi, ainda, testada, por meio do teste Mann-Whitney para amostras independentes, se a média do valor adicionado distribuído aos empregados pelo grupo de empresas da ZFM que contabilizam os incentivos fiscais de forma errada (ZFM_E) é igual à média dos demais grupos comparados.

As hipóteses testadas foram:

$\mathrm{H}_{0}: \mu_{P_{-} Z \text { ZFM_E }}=\mu_{P_{-} \text {FOR_T }}$

$\mathrm{H}_{1}$ : Existe diferença entre as médias.

$\mathrm{H}_{0}: \mu_{\mathrm{P}_{-} Z \mathrm{ZF}} \mathrm{E}=\mu_{\mathrm{P} \_ \text {FOR_A }}$

$\mathrm{H}_{1}$ : Existe diferença entre as médias.

$\mathrm{H}_{0}: \mu_{\mathrm{P} \_ \text {ZFM_E }}=\mu_{\mathrm{P} \_ \text {FOR_B }}$

$\mathrm{H}_{1}$ : Existe diferença entre as médias.

Os resultados do teste não paramétrico aplicado constataram que há diferença significativa entre a média de valor adicionado distribuídos ao pessoal do grupo de empresas da ZFM 
(P_ZFM_E) e grupo de empresas fora da ZFM do setor de autoindústria (P_FOR_A) com um nível de nível de significância de 5\%, conforme disposto na Tabela 38.

Por outro lado, não há evidências que possam levar a rejeitar a $H_{0}$ quando comparadas com os grupos de empresas dos setores fora da ZFM (P_FOR_T) e do grupo de empresas dos setores de bens de consumo, indústria digital e eletroeletrônico fora da ZFM (P_FOR_B).

Tabela 38 - Teste de média do valor adicionado distribuído a pessoal entre o grupo ZFM_E e outros grupos

\begin{tabular}{c|l|c|c|c|c|l}
\hline Grupo & $\begin{array}{c}\text { Grupo } \\
\text { Comparação }\end{array}$ & $\begin{array}{c}\mathbf{N}^{\mathbf{0}} \\
\text { observações }\end{array}$ & $\begin{array}{c}\text { Média } \\
\text { amostral }\end{array}$ & $\begin{array}{c}\text { Estatística } \\
\mathbf{Z}\end{array}$ & $\begin{array}{c}\text { Nível de } \\
\text { significância }\end{array}$ & \multicolumn{1}{|c}{ Resultado } \\
\hline P_ZFM_E & & 54 & 0,2895 & & & \\
& P_FOR_T & 37 & 0,3357 & $-1,818$ & 0,069 & Não Rejeita H0 \\
& P_FOR_A & 13 & 0,3640 & $-2,061$ & 0,039 & Rejeita H0 \\
& P_FOR_B & 24 & 0,3203 & $-1,028$ & 0,304 & Não Rejeita H0 \\
\hline
\end{tabular}

Essa tabela apresenta resultados de teste de amostras independentes que verificou se a média entre P_ZFM_C e P_FOR_T, P_FOR_A e P_FOR_B, é estatisticamente diferente de zero. P_ZFM_C referese ao percentual de valor adicionado estimado distribuído aos empregados pelo grupo total de empresas da Zona Franca de Manaus que contabilizam os incentivos fiscais de forma errada. P_FOR_T refere-se ao percentual de valor adicionado estimado distribuído aos empregados pelo grupo total de empresas fora da Zona Franca de Manaus. P_FOR_A refere-se ao percentual de valor adicionado estimado distribuído aos empregados pelas empresas do setor autoindústrias fora da Zona Franca de Manaus. P_FOR_B refere-se ao percentual de valor adicionado estimado distribuído aos empregados pelas empresas do setor bens de consumo, eletroeletrônico e indústria digital fora da Zona Franca de Manaus.

Para o grupo de empresas pares foi realizado o teste de média para amostras emparelhadas, no qual se busca descobrir se existe diferença entre a média do valor adicionado distribuído aos empregados do grupo de Empresas da ZFM e a média do grupo de Empresas Pares. Assim, o teste $t$, paramétrico, para médias emparelhadas, procura testar as seguintes hipóteses:

$$
\begin{aligned}
& \mathrm{H}_{0}: \mu_{\text {Pes (ZFM - Pares })}=0 \\
& \mathrm{H}_{1}: \mu_{\text {Pes (ZFM - Pares) }} \neq 0
\end{aligned}
$$

em que:

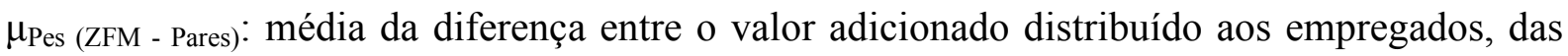
empresas da Zona Franca de Manaus em relação às respectivas empresas pares instaladas fora da ZFM. 
Tabela 39 - Teste de média do valor adicionado distribuído a pessoal de amostras emparelhadas

\begin{tabular}{lccc}
\hline \multicolumn{1}{c}{ Variáveis } & P_ZFM & P_PARES & P_ZFM - P_PARES \\
\hline Média da amostra & 0,2728 & 0,3631 & $-0,0903$ \\
Desvio padrão da amostra & 0,1589 & 0,1794 & \\
Diferença máxima & & & $-0,0381$ \\
Diferença mínima & & & $-0,1426$ \\
Desvio padrão da diferença & & & 0,2239 \\
Estatística t & & $-3,447$ \\
Nível de significância & & 0,001 \\
\hline
\end{tabular}

73 observações para cada amostra e teste t com 72 graus de liberdade

Essa tabela apresenta resultados de teste de amostras emparelhadas que verificaram se a diferença entre P_ZFM - P_PARES, calculada para cada par de empresas, é,

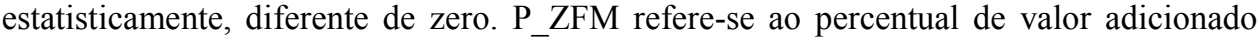
estimado distribuído aos empregados pelo grupo de empresas da Zona Franca de Manaus. P_PARES refere-se ao percentual de valor adicionado estimado distribuído aos empregados pelo grupo de empresas fora da Zona Franca de Manaus.

Para as empresas industriais instaladas na ZFM, a média do valor adicionado distribuído aos empregados é de $27,28 \%$, enquanto para as empresas pares instaladas fora da ZFM é de $36,31 \%$. A diferença resultante foi de $9,03 \%$ e pode ser interpretada como o valor de riqueza distribuída a mais aos empregados pelo grupo de empresas pares, estatisticamente significante ao nível de 5\% (0,001), conforme disposto na Tabela 39. Logo, obtém-se a seguinte equação:

$$
\left[\text { Pes }_{\mathrm{ZFM}}-\text { Pes Pares }\right]=-0,0903
$$

Os resultados, apresentados no Quadro 25, foram obtidos a partir dos dados constantes dos Apêndices 8, 9, 10, 11 e 14 que mostram, respectivamente, o percentual de distribuição de riqueza aos empregados pelas empresas, por meio das suas DVAs consolidadas, no período de 2003 a 2007.

Quadro 25 - Distribuição de riqueza aos empregados das DVAs consolidadas (\%)

\begin{tabular}{|l|l|l|l|l|l|}
\hline \multicolumn{1}{|c|}{ Grupo Empresas } & $\mathbf{2 0 0 3}$ & $\mathbf{2 0 0 4}$ & $\mathbf{2 0 0 5}$ & $\mathbf{2 0 0 6}$ & $\mathbf{2 0 0 7}$ \\
\hline Empresas ZFM & 19,48 & 14,94 & 16,63 & 19,77 & 19,14 \\
Empresas ZFM Corretas & 13,49 & 11,45 & 11,68 & 16,41 & 21,82 \\
Empresas ZFM Erradas & 23,24 & 17,02 & 19,22 & 24,11 & 17,15 \\
Setores Fora ZFM * & 36,50 & 37,35 & 11,51 & 12,88 & 14,13 \\
Empresas Pares & 27,17 & 23,96 & 34,64 & 29,86 & 43,60 \\
\hline
\end{tabular}

* Compreende os setores de autoindústria, bens de consumo, indústria digital e eletroeletrônico 
Da análise do Quadro 25, chega-se à conclusão de que os setores fora da ZFM, nos anos de 2005 a 2007, apresentam dispersões, oscilações, em decorrência do número reduzido de empresas e por incluir empresa do setor de fumos no setor de bens de consumo, distorcendo o percentual de distribuição de riqueza aos empregados.

Por fim, ao comparar as empresas da ZFM com as empresas pares, por meio do Gráfico 6, observa-se que as empresas industriais instaladas na ZFM distribuem menos riqueza aos empregados do que as empresas pares.

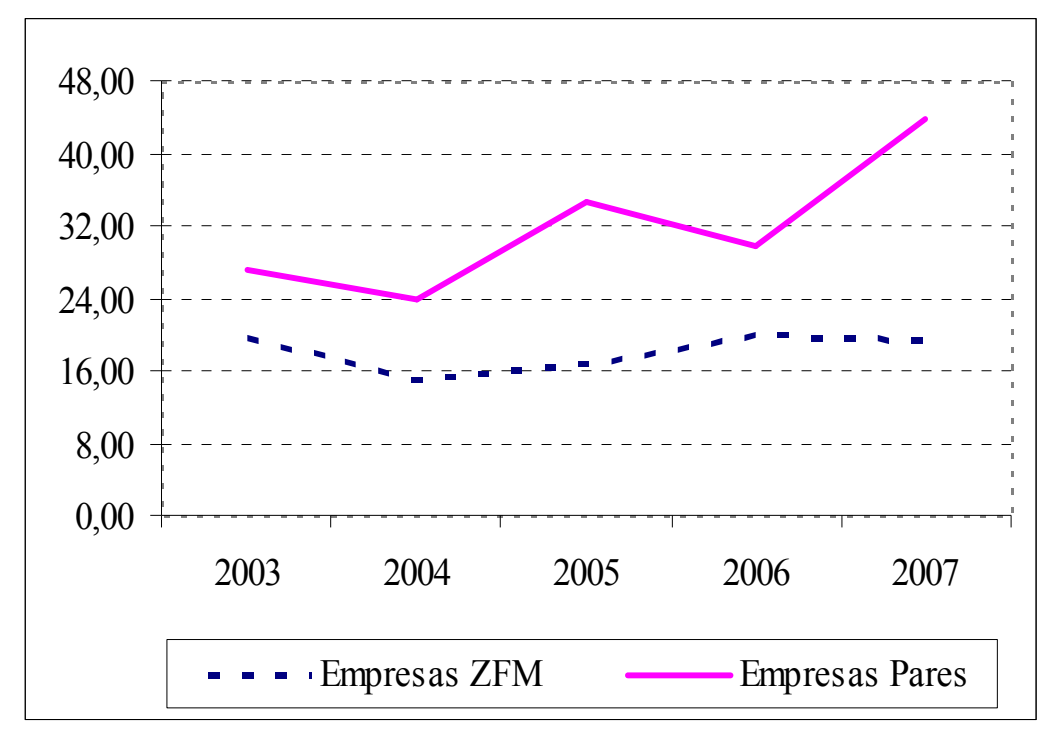

Gráfico 6 - Distribuição de riqueza aos empregados (\%)

Diante desses dados e atendendo ao objetivo específico proposto de mensurar a distribuição de riqueza aos empregados, pelas empresas industriais beneficiárias de incentivos fiscais instaladas na Zona Franca de Manaus, pelo teste de média (27,28\% contra 36,31\%) e pelas DVAs reais consolidadas, rejeita-se a hipótese auxiliar 3, ou seja, as empresas industriais instaladas na ZFM distribuem uma parcela menor de riqueza aos empregados do que as empresas industriais dos mesmos setores ou similares instaladas em outras regiões do País. 


\subsubsection{Governo}

A distribuição de riqueza para os governos é testada por meio da hipótese auxiliar 4, assim especificada:

\section{HA4: As empresas industriais, instaladas na Zona Franca de Manaus e beneficiadas} com incentivos fiscais, que elaboram ou publicam a Demonstração de Valor Adicionado, distribuem uma parcela menor da riqueza aos governos do que as empresas industriais do mesmo setor ou similares instaladas em outras regiões do país.

A Tabela 40 mostra o percentual de distribuição do valor adicionado pela empresa para a parte interessada governos. Foi utilizada a estatística descritiva para calcular a média da amostra das empresas com DVA. No período estudado, verifica-se que, da riqueza distribuída, em média, os governos recebem $54,42 \%$ do grupo de empresas industriais da ZFM (G ZFM T), 58,15\% do grupo de empresas da ZFM que contabilizam os incentivos fiscais de forma incorreta (G_ZFM_E) e 41,54\% do grupo de empresas pares (G_PARES).

\begin{tabular}{l|r|r|r|r|r|r}
\multicolumn{6}{c}{ Tabela 40 - Estatísticas descritivas para o valor adicionado distribuído ao governo } \\
\hline Grupo & $\begin{array}{c}\text { No de } \\
\text { observações }\end{array}$ & \multicolumn{1}{c|}{ Média } & Mínimo & Máximo & Mediana & $\begin{array}{c}\text { Desvio- } \\
\text { padrão }\end{array}$ \\
\hline G_ZFM_T & 73 & 0,5442 & 0,1136 & 1,2446 & 0,5407 & 0,2346 \\
G_ZFM_C & 19 & 0,4381 & 0,2332 & 0,607 & 0,4306 & 0,0970 \\
G_ZFM_E & 54 & 0,5815 & 0,1136 & 1,2446 & 0,5712 & 0,2572 \\
G_FOR_T & 37 & 0,3235 & 0,0941 & 0,6133 & 0,3236 & 0,1614 \\
G_FOR_A & 13 & 0,2147 & 0,0941 & 0,3494 & 0,2092 & 0,0867 \\
G_FOR_B & 24 & 0,3825 & 0,0978 & 0,6133 & 0,4264 & 0,1628 \\
G_PARES & 73 & 0,4154 & 0,0954 & 0,8454 & 0,4208 & 0,1865 \\
\hline
\end{tabular}

Foi aplicado o teste Mann-Whitney por se tratar de um teste para amostras independentes no qual se procura conhecer se a média do valor adicionado distribuído aos empregados pelo grupo de empresas da ZFM (ZFM_T) é igual à média dos demais grupos comparados. 
As hipóteses testadas foram:

$$
\begin{aligned}
& \mathrm{H}_{0}: \mu_{\mathrm{G}_{-} \mathrm{ZFM}} \mathrm{T}=\mu_{\mathrm{G}_{-} \mathrm{FOR} \_\mathrm{T}} \\
& \mathrm{H}_{1}: \text { Existe diferença entre as médias. }
\end{aligned}
$$

$\mathrm{H}_{0}: \mu_{\mathrm{G} \_ \text {ZFM_T }}=\mu_{\mathrm{G} \_ \text {FOR_A }}$

$\mathrm{H}_{1}$ : Existe diferença entre as médias.

$$
\begin{aligned}
& \mathrm{H}_{0}: \mu_{\mathrm{G}_{-} \mathrm{ZFM}} \mathrm{T}=\mu_{\mathrm{G} \_\mathrm{FOR} \_} \mathrm{B} \\
& \mathrm{H}_{1}: \text { Existe diferença entre as médias. }
\end{aligned}
$$

Os resultados do teste não paramétrico aplicado constataram que há diferença significativa entre a média de valor adicionado distribuídos aos governos do grupo de empresas da ZFM (G_ZFM_T) e os demais grupos com um nível de nível de significância de 5\%, conforme disposto na Tabela 41 .

Tabela 41 - Teste de média do valor adicionado distribuído aos governos entre o grupo ZFM T e outros grupos

\begin{tabular}{c|l|c|c|c|c|c}
\hline Grupo & $\begin{array}{c}\text { Grupo } \\
\text { Comparação }\end{array}$ & $\begin{array}{c}\mathbf{N}^{\circ} \\
\text { observações }\end{array}$ & $\begin{array}{c}\text { Média } \\
\text { amostral }\end{array}$ & $\begin{array}{c}\text { Estatística } \\
\mathbf{Z}\end{array}$ & $\begin{array}{c}\text { Nível de } \\
\text { significância }\end{array}$ & Resultado \\
\hline G_ZFM_T & & 73 & 0,5442 & & & \\
& G_FOR_T & 37 & 0,3235 & $-4,754$ & 0,000 & Rejeita H0 \\
& G_FOR_A & 13 & 0,2147 & $-4,973$ & 0,000 & Rejeita H0 \\
& G_FOR_B & 24 & 0,3825 & $-2,834$ & 0,005 & Rejeita H0 \\
\hline
\end{tabular}

Essa tabela apresenta resultados de teste de amostras independentes que verificou se a média entre G_ZFM_T e G_FOR_T, G_FOR_A e G_FOR_B é, estatisticamente, diferente de zero. G_ZFM_T refere-se ao percentual de valor adicionado estimado distribuído aos governos pelo grupo total $\overline{\text { de }}$ empresas da Zona Franca de Manaus. G_FOR_T refere-se ao percentual de valor adicionado estimado distribuído aos governos pelo grupo total de empresas fora da Zona Franca de Manaus. G_FOR_A refere-se ao percentual de valor adicionado estimado distribuído aos governos pelas empresas do setor autoindústrias fora da Zona Franca de Manaus. G_FOR_B refere-se ao percentual de valor adicionado estimado distribuído aos governos pelas empresas do setor bens de consumo, eletroeletrônico e indústria digital fora da Zona Franca de Manaus.

Além disso, cabe destacar que há diferença significativa entre a média de valor adicionado distribuído ao governo, evidenciada pelo grupo de empresas da ZFM (G_ZFM_C) que efetuaram a contabilização dos incentivos fiscais de forma correta e os grupos que não fizeram a adequada contabilização. 
De igual forma, foi aplicado o teste Mann-Whitney às amostras independentes para testar se a média do valor adicionado distribuído aos governos pelo grupo de empresas da ZFM que contabilizam os incentivos fiscais de forma correta (ZFM_C) é igual à média dos demais grupos comparados.

As hipóteses testadas foram:

$$
\begin{aligned}
& \mathrm{H}_{0}: \mu_{\mathrm{G} \_\mathrm{ZFM}} \mathrm{C}=\mu_{\mathrm{G} \_\mathrm{ZFM} \_\mathrm{E}} \\
& \mathrm{H}_{1} \text { : Existe diferença entre as médias. } \\
& \mathrm{H}_{0}: \mu_{\mathrm{G} \_ \text {ZFM_C }}=\mu_{\mathrm{G}_{-} \mathrm{FOR} \_\mathrm{T}} \\
& \mathrm{H}_{1} \text { : Existe diferença entre as médias. } \\
& \mathrm{H}_{0}: \mu_{\mathrm{G}_{-} \mathrm{ZFM} \_\mathrm{C}=} \mu_{\mathrm{G} \_ \text {FOR_A }} \mathrm{A} \\
& \mathrm{H}_{1} \text { : Existe diferença entre as médias. } \\
& \mathrm{H}_{0}: \mu_{\mathrm{G}_{-} \mathrm{ZFM} \_\mathrm{C}}=\mu_{\mathrm{G} \_ \text {FOR_B }} \\
& \mathrm{H}_{1} \text { : Existe diferença entre as médias }
\end{aligned}
$$

Os resultados do teste não paramétrico aplicado constataram que há diferença significativa entre a média de valor adicionado distribuídos aos governos do grupo de empresas da ZFM (G_ZFM_C) e os grupos de empresas dos setores fora da ZFM (G_FOR_T), grupo de empresas fora da ZFM do setor de autoindústria (G_FOR_A) com um nível de significância de 5\%, conforme disposto na Tabela 42, a seguir.

Por outro lado, não há evidências que possam levar a rejeitar a $\mathrm{H}_{0}$ quando comparada com e do grupo de empresas dos setores de bens de consumo, indústria digital e eletroeletrônica fora da ZFM (G_FOR_B). 
Tabela 42 - Teste de média do valor adicionado distribuído aos governos entre o grupo ZFM_C e outros grupos

\begin{tabular}{c|l|c|c|c|c|l}
\hline Grupo & $\begin{array}{c}\text { Grupo } \\
\text { Comparação }\end{array}$ & $\begin{array}{c}\mathbf{N}^{\mathbf{0}} \\
\text { observações }\end{array}$ & $\begin{array}{c}\text { Média } \\
\text { amostral }\end{array}$ & $\begin{array}{c}\text { Estatística } \\
\text { Z }\end{array}$ & $\begin{array}{c}\text { Nível de } \\
\text { significância }\end{array}$ & \multicolumn{1}{|c}{ Resultado } \\
\hline G_ZFM_C & & 19 & 0,4381 & & & \\
& & & & & & \\
& G_ZFM_E & 54 & 0,5815 & $-2,338$ & 0,019 & Rejeita H0 \\
& G_FOR_T & 37 & 0,3235 & $-2,604$ & 0,009 & Rejeita H0 \\
& G_FOR_A & 13 & 0,2147 & $-4,470$ & 0,000 & Rejeita H0 \\
& G_FOR_B & 24 & 0,3825 & $-0,831$ & 0,406 & Não Rejeita H0 \\
\hline
\end{tabular}

Essa tabela apresenta resultados de teste de amostras independentes que verificou se a média entre G_ZFM_C e G_FOR_T, G_FOR_A e G_FOR_B é, estatisticamente, diferente de zero. G_ZFM_C refere-se ao percentual de valor adicionado estimado distribuído aos governos pelo grupo total de empresas da Zona Franca de Manaus que contabilizam os incentivos fiscais de forma correta. G_FOR_T refere-se ao percentual de valor adicionado estimado distribuído aos governos pelo grupo total de empresas fora da Zona Franca de Manaus. G_FOR_A refere-se ao percentual de valor adicionado estimado distribuído aos governos pelas empresas do setor autoindústrias fora da Zona Franca de Manaus. G_FOR_B refere-se ao percentual de valor adicionado estimado distribuído aos governos pelas empresas do setor bens de consumo, eletroeletrônico e indústria digital fora da Zona Franca de Manaus.

Foi, ainda, testada, por meio do teste Mann-Whitney para amostras independentes, se a média do valor adicionado distribuído aos governos pelo grupo de empresas da ZFM que contabilizam os incentivos fiscais de forma errada (ZFM_E) é igual à média dos demais grupos comparados.

As hipóteses testadas foram:

$$
\begin{aligned}
& \mathrm{H}_{0}: \mu_{\mathrm{G}_{-} \mathrm{ZFM}} \mathrm{E}=\mu_{\mathrm{G}_{-} \mathrm{FOR}_{-} \mathrm{T}} \\
& \mathrm{H}_{1}: \text { Existe diferença entre as médias. }
\end{aligned}
$$

$\mathrm{H}_{0}: \mu_{\mathrm{G} \_\mathrm{ZFM}} \mathrm{E}=\mu_{\mathrm{G} \_ \text {FOR_A }}$

$\mathrm{H}_{1}$ : Existe diferença entre as médias.

$$
\begin{aligned}
& \mathrm{H}_{0}: \mu_{\mathrm{G}_{-} \mathrm{ZFM}} \mathrm{E}=\mu_{\mathrm{G}_{-} \mathrm{FOR}_{-} \mathrm{B}} \\
& \mathrm{H}_{1}: \text { Existe diferença entre as médias }
\end{aligned}
$$

Os resultados do teste não paramétrico aplicado constataram que há diferença significativa entre a média de valor adicionado distribuídos aos governos do grupo de empresas da ZFM (G_ZFM_E) e os demais grupos com um nível de nível de significância de 5\%, conforme disposto na Tabela 43, a seguir. 
Tabela 43 - Teste de média do valor adicionado distribuído aos governos entre o grupo ZFM_E e outros grupos

\begin{tabular}{c|l|c|c|c|c|c}
\hline \multicolumn{1}{c|}{ Grupo } & \multicolumn{1}{c|}{$\begin{array}{c}\text { Grupo } \\
\text { Comparação }\end{array}$} & $\begin{array}{c}\mathbf{N}^{\circ} \\
\text { observações }\end{array}$ & $\begin{array}{c}\text { Média } \\
\text { amostral }\end{array}$ & $\begin{array}{c}\text { Estatística } \\
\mathbf{Z}\end{array}$ & $\begin{array}{c}\text { Nível de } \\
\text { significância }\end{array}$ & Resultado \\
\hline G_ZFM_E & & 54 & 0,5815 & & & \\
& G_FOR_T & 37 & 0,3235 & $-4,856$ & 0,000 & Rejeita H0 \\
& G_FOR_A & 13 & 0,2147 & $-4,693$ & 0,000 & Rejeita H0 \\
& G_FOR_B & 24 & 0,3825 & $-3,302$ & 0,001 & Rejeita H0 \\
\hline
\end{tabular}

Essa tabela apresenta resultados de teste de amostras independentes que verificou se a média entre G_ZFM_C e G_FOR_T, G_FOR_A e G_FOR_B é, estatisticamente, diferente de zero. G_ZFM_C refere-se ao percentual de valor adicionado estimado distribuído aos governos pelo grupo total de empresas da Zona Franca de Manaus que contabilizam os incentivos fiscais de forma errada. G_FOR_T refere-se ao percentual de valor adicionado estimado distribuído aos governos pelo grupo total de empresas fora da Zona Franca de Manaus. G_FOR_A refere-se ao percentual de valor adicionado estimado distribuído aos governos pelas empresas do setor autoindústrias fora da Zona Franca de Manaus. G_FOR_B refere-se ao percentual de valor adicionado estimado distribuído aos governos pelas empresas do setor bens de consumo, eletroeletrônico e indústria digital fora da Zona Franca de Manaus.

Para o grupo de empresas pares foi realizado o teste de média para amostras emparelhadas, no qual se busca descobrir se existe diferença entre a média do valor adicionado distribuído aos governos do grupo de Empresas da ZFM e a média do grupo de Empresas Pares. Assim, o teste $t$, paramétrico, para médias emparelhadas procura testar as seguintes hipóteses:

$$
\begin{aligned}
& \mathrm{H}_{0}: \mu_{\mathrm{Gov} \text { (ZFM - Pares) }}=0 \\
& \mathrm{H}_{1}: \mu_{\mathrm{Gov} \text { (ZFM - Pares) }} \neq 0
\end{aligned}
$$

em que:

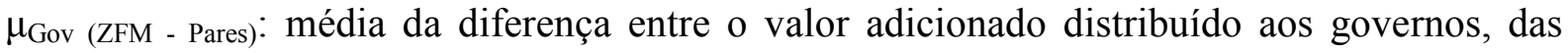
empresas da Zona Franca de Manaus em relação às respectivas empresas pares instaladas fora da ZFM.

\begin{tabular}{|c|c|c|c|}
\hline Variáveis & G_ZFM & G_PARES & G_ZFM - G_PARES \\
\hline Média da amostra & 0,5442 & 0,4154 & 0,1288 \\
\hline Desvio-padrão da amostra & 0,2346 & 0,1865 & \\
\hline Diferença máxima & & & 0,2010 \\
\hline Diferença mínima & & & 0,0565 \\
\hline Desvio-padrão da diferença & & & 0,3096 \\
\hline Estatística $\mathrm{t}$ & & & 3,553 \\
\hline Nível de significância & & & 0,001 \\
\hline \multicolumn{4}{|c|}{73 observações para cada amostra e teste t com 72 graus de liberdade } \\
\hline \multicolumn{4}{|c|}{$\begin{array}{l}\text { Essa tabela apresenta resultados de teste de amostras emparelhadas que verificou se a } \\
\text { diferença entre G_ZFM - G_PAR, calculada para cada par de empresas, é, } \\
\text { estatisticamente, diferente de zero. G_ZFM refere-se ao percentual de valor adicionado } \\
\text { estimado distribuído aos governos pelo grupo de empresas da Zona Franca de Manaus. } \\
\text { G_PARES refere-se ao percentual de valor adicionado estimado distribuído aos governos } \\
\text { pelo grupo de empresas fora da Zona Franca de Manaus. }\end{array}$} \\
\hline
\end{tabular}

Tabela 44 - Teste de média do valor adicionado distribuído aos governos de amostras emparelhadas 
Para as empresas industriais instaladas na ZFM, a média do valor adicionado distribuído aos governos é de 54,42\%, enquanto para as empresas pares instaladas fora da ZFM é de 41,54\%. A diferença resultante de $12,88 \%$, estatisticamente significante ao nível de 5\% $(0,001)$, pode ser interpretada como o valor de riqueza distribuída a mais aos governos pelo grupo de empresas instaladas na ZFM, conforme disposto na Tabela 44. Logo, obtém-se a seguinte equação:

$$
\left[\text { GovZFM }_{\text {ZFov }} \text { Pares }\right]=0,1288
$$

O Quadro 26 apresenta os resultados obtidos a partir dos dados constantes dos Apêndices 8, 9, 10, 11 e 14, que mostram, respectivamente, o percentual de distribuição de riqueza aos governos pelas empresas por meio das suas DVAs consolidadas, no período de 2003 a 2007.

Quadro 26 - Distribuição de riqueza aos governos das DVAs consolidadas (\%)

\begin{tabular}{|l|c|c|c|c|c|}
\hline \multicolumn{1}{|c|}{ Grupo Empresas } & $\mathbf{2 0 0 3}$ & $\mathbf{2 0 0 4}$ & $\mathbf{2 0 0 5}$ & $\mathbf{2 0 0 6}$ & $\mathbf{2 0 0 7}$ \\
\hline Empresas ZFM & 56,21 & 58,86 & 49,00 & 49,25 & 58,67 \\
Empresas ZFM Corretas & 47,11 & 51,33 & 42,79 & 44,19 & 47,75 \\
Empresas ZFM Erradas & 61,94 & 63,36 & 52,24 & 55,79 & 66,80 \\
Setores Fora ZFM * & 22,13 & 24,55 & 67,20 & 64,96 & 65,30 \\
Empresas Pares & 35,99 & 35,05 & 44,25 & 58,78 & 44,81 \\
\hline
\end{tabular}

* Compreende os setores de autoindústria, bens de consumo, indústria digital e eletroeletrônico

Da análise do Quadro 26, chega-se às seguintes conclusões:

- $\quad$ os setores fora da ZFM, nos anos de 2005 a 2007, apresentam dispersões, oscilações, em decorrência do número reduzido de empresas e por incluir empresa do setor de fumos no setor de bens de consumo, distorcendo o percentual de distribuição de riqueza aos governos;

- $\quad$ as empresas da ZFM que contabilizam os incentivos de forma errada evidenciam e divulgam, de maneira equivocada, um maior valor de riqueza distribuída aos governos, em parte por considerar o valor total do ICMS sobre as vendas na DRE. 
Ao comparar as empresas da ZFM com as empresas pares, por meio do Gráfico 7, observa-se que as empresas industriais instaladas na ZFM distribuem mais riqueza aos governos do que as empresas pares, com exceção do ano de 2006.

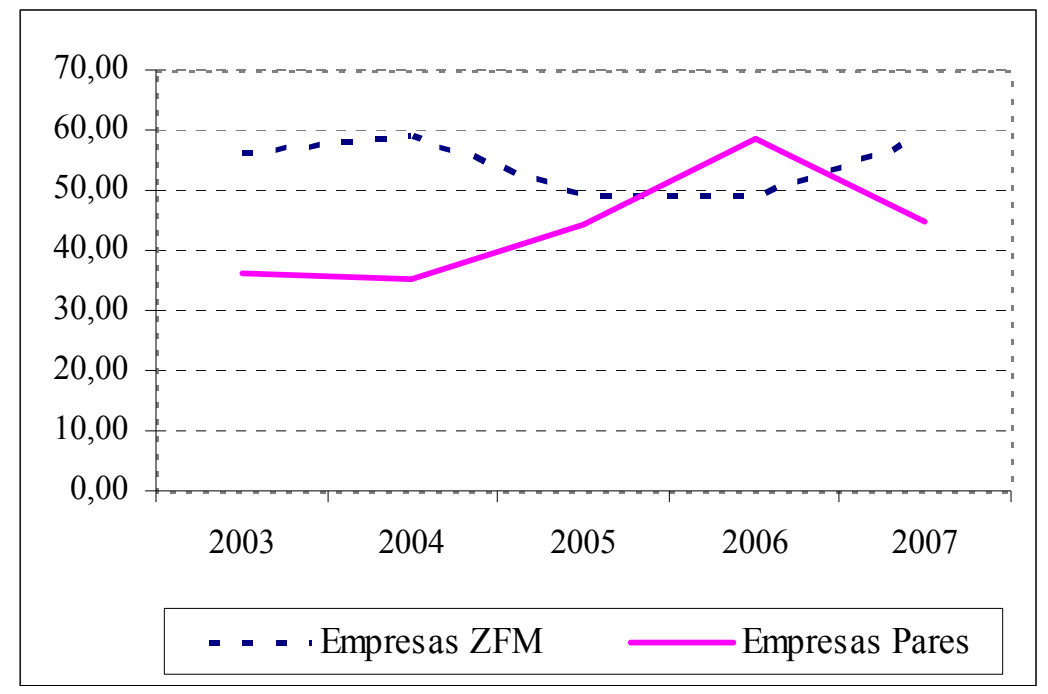

Gráfico 7 - Distribuição de riqueza aos governos (\%)

Em resumo, atendendo ao objetivo específico proposto de mensurar a distribuição de riqueza aos governos, pelas empresas industriais beneficiárias de incentivos fiscais instaladas na Zona Franca de Manaus, pelo teste de média $(54,42 \%$ contra $41,54 \%)$ e pelas DVAs reais consolidadas, rejeita-se a hipótese auxiliar 4, ou seja, as empresas industriais instaladas na ZFM distribuem uma parcela maior de riqueza aos governos do que as empresas industriais dos mesmos setores ou similares instaladas em outras regiões do País.

\subsubsection{Proprietários}

A distribuição de riqueza aos proprietários é testada por meio da hipótese auxiliar 5 , assim especificada:

HA5: As empresas industriais, instaladas na Zona Franca de Manaus e beneficiadas com incentivos fiscais, que elaboram ou publicam a Demonstração de Valor Adicionado, distribuem uma parcela maior da riqueza aos proprietários do que as empresas industriais do mesmo setor ou similares instaladas em outras regiões do país. 
A Tabela 45 mostra o percentual de distribuição do valor adicionado pela empresa para a parte interessada proprietários. Foi utilizada a estatística descritiva para calcular a média da amostra das empresas com Demonstração de Valor Adicionado (DVA). No período estudado, verifica-se que, da riqueza distribuída, em média, os proprietários recebem 1,82\% do grupo de empresas industriais da ZFM (A_ZFM_T) e 6,44\% do grupo de empresas pares (A_PARES).

Tabela 45 - Estatísticas descritivas para o valor adicionado distribuído aos acionistas

\begin{tabular}{l|c|r|r|r|r|r}
\hline \multicolumn{1}{c|}{ Grupo } & $\begin{array}{c}\text { No de } \\
\text { observações }\end{array}$ & \multicolumn{1}{c|}{ Média } & Mínimo & Máximo & Mediana & \multicolumn{1}{c}{$\begin{array}{c}\text { Desvio- } \\
\text { padrão }\end{array}$} \\
\hline A_ZFM_T & 73 & 0,0182 & $-0,6738$ & 0,5235 & 0,0524 & 0,2925 \\
A_ZFM_C & 19 & 0,2441 & $-0,1022$ & 0,5235 & 0,2738 & 0,1751 \\
A_ZFM_E & 54 & $-0,0613$ & $-0,6737$ & 0,4519 & $-0,0276$ & 0,2848 \\
A_FOR_T & 37 & 0,1835 & $-0,2719$ & 0,4347 & 0,1762 & 0,1267 \\
A_FOR_A & 13 & 0,2367 & 0,1057 & 0,4347 & 0,1966 & 0,1056 \\
A_FOR_B & 24 & 0,1546 & $-0,2719$ & 0,3274 & 0,1697 & 0,1298 \\
A_PARES & 73 & 0,0644 & $-0,8188$ & 0,4122 & 0,0643 & 0,1597 \\
\hline
\end{tabular}

Foi aplicado o teste Mann-Whitney por se tratar de um teste para amostras independentes, no qual se procura conhecer se a média do valor adicionado distribuído aos proprietários pelo grupo de empresas da ZFM (ZFM_T) é igual à média dos demais grupos comparados.

As hipóteses testadas foram:

$$
\begin{aligned}
& \mathrm{H}_{0}: \mu_{\mathrm{A} \_ \text {ZFM_T }}=\mu_{\mathrm{A} \_ \text {FOR_T }} \\
& \mathrm{H}_{1} \text { : Existe diferença entre as médias. } \\
& \mathrm{H}_{0}: \mu_{\text {A_ZFM_T }}=\mu_{\text {A_FOR_A }} \\
& \mathrm{H}_{1} \text { : Existe diferença entre as médias. } \\
& \mathrm{H}_{0}: \mu_{\mathrm{A} \_ \text {ZFM_T }}=\mu_{\text {A_FOR_B }} \\
& \mathrm{H}_{1} \text { : Existe diferença entre as médias. }
\end{aligned}
$$

Os resultados do teste não paramétrico aplicado constataram que há diferença significativa entre a média de valor adicionado distribuído aos governos do grupo de empresas da ZFM (A_ZFM_T) e os demais grupos com um nível de nível de significância de 5\%, conforme disposto na Tabela 46, a seguir. 
Tabela 46 - Teste de média do valor adicionado distribuído aos proprietários entre o grupo ZFM T e outros grupos

\begin{tabular}{l|l|c|c|c|c|l}
\hline Grupo & $\begin{array}{c}\text { Grupo } \\
\text { Comparação }\end{array}$ & $\begin{array}{c}\mathbf{N}^{\mathbf{0}} \\
\text { observações }\end{array}$ & $\begin{array}{c}\text { Média } \\
\text { amostral }\end{array}$ & $\begin{array}{c}\text { Estatística } \\
\mathbf{Z}\end{array}$ & $\begin{array}{c}\text { Nível de } \\
\text { significância }\end{array}$ & Resultado \\
\hline A_ZFM_T & A_FOR_T & 37 & 0,1817 & & & \\
& A_FOR_A & 13 & 0,1835 & $-2,951$ & 0,003 & Rejeita H0 \\
& A_FOR_B & 24 & 0,1546 & $-2,023$ & 0,043 & Rejeita H0 \\
\hline
\end{tabular}

Essa tabela apresenta resultados de teste de amostras independentes que verificou se a média entre A_ZFM_T e A_FOR_T, A_FOR_A e A_FOR_B é, estatisticamente, diferente de zero. A_ZFM_T refere-se ao percentual de valor adicionado estimado distribuído aos acionistas pelo grupo total $\overline{\text { de }}$ empresas da Zona Franca de Manaus. A_FOR_T refere-se ao percentual de valor adicionado estimado distribuído aos acionistas pelo grupo total de empresas fora da Zona Franca de Manaus. A_FOR_A refere-se ao percentual de valor adicionado estimado distribuído aos acionistas pelas empresas do setor autoindústrias fora da Zona Franca de Manaus. A_FOR_B refere-se ao percentual de valor adicionado estimado distribuído aos acionistas pelas empresas do setor bens de consumo, eletroeletrônico e indústria digital fora da Zona Franca de Manaus.

Da mesma maneira, foi aplicado o teste Mann-Whitney para amostras independentes para testar se a média do valor adicionado distribuído aos proprietários pelo grupo de empresas da ZFM que contabilizam os incentivos fiscais de forma correta (ZFM_C) é igual à média dos demais grupos comparados.

As hipóteses testadas foram:

$$
\begin{aligned}
& \mathrm{H}_{0}: \mu_{\mathrm{A} \_\mathrm{ZFM}} \mathrm{C}=\mu_{\mathrm{A} \_\mathrm{ZFM}} \mathrm{E} \\
& \mathrm{H}_{1}: \text { Existe diferença entre as médias. }
\end{aligned}
$$

$$
\begin{aligned}
& \mathrm{H}_{0}: \mu_{\mathrm{A} \_Z F M}{ }_{-}=\mu_{\mathrm{A} \_} \mathrm{FOR}_{-} \mathrm{T} \\
& \mathrm{H}_{1}: \text { Existe diferença entre as médias. }
\end{aligned}
$$

$\mathrm{H}_{0}: \mu_{\mathrm{A} \_ \text {ZFM_C }}=\mu_{\mathrm{A} \_ \text {FOR_A }}$

$\mathrm{H}_{1}$ : Existe diferença entre as médias.

$$
\begin{aligned}
& \mathrm{H}_{0}: \mu_{\mathrm{A} \_ \text {ZFM_C }}=\mu_{\mathrm{A}_{-} \mathrm{FOR}_{-} \mathrm{B}} \\
& \mathrm{H}_{1}: \text { Existe diferença entre as médias. }
\end{aligned}
$$

Os resultados do teste não paramétrico aplicado constataram que há diferença significativa entre a média de valor adicionado distribuído aos governos do grupo de empresas da ZFM 
(A_ZFM_C) e os grupos de empresas da ZFM que contabiliza os incentivos de forma incorreta (G_ZFM_E) com um nível de significância de 5\%, de acordo com a Tabela 47.

Por outro lado, não há evidências que possam levar a rejeitar a $H_{0}$ quando comparada com os demais grupos.

Tabela 47 - Teste de média do valor adicionado distribuído aos proprietários entre o grupo ZFM_C e outros grupos

\begin{tabular}{c|l|c|c|c|c|l}
\hline \multirow{2}{*}{ Grupo } & $\begin{array}{c}\text { Grupo } \\
\text { Comparação }\end{array}$ & $\begin{array}{c}\mathbf{N}^{\mathbf{0}} \\
\text { observações }\end{array}$ & $\begin{array}{c}\text { Média } \\
\text { amostral }\end{array}$ & $\begin{array}{c}\text { Estatística } \\
\mathbf{Z}\end{array}$ & $\begin{array}{c}\text { Nível de } \\
\text { significância }\end{array}$ & Resultado \\
\hline A_ZFM_C & 19 & 0,2441 & & & \\
& A_ZFM_E & 54 & $-0,0613$ & $-4,086$ & 0,000 & Rejeita H0 \\
& A_FOR_T & 37 & 0,1835 & $-1,324$ & 0,186 & Não Rejeita H0 \\
& A_FOR_A & 13 & 0,2367 & $-0,211$ & 0,833 & Não Rejeita H0 \\
& A_FOR_B & 24 & 0,1546 & $-1,736$ & 0,082 & Não Rejeita H0 \\
\hline
\end{tabular}

Essa tabela apresenta resultados de teste de amostras independentes que verificou se a média entre A_ZFM_C e A_FOR_T, A_FOR_A e A_FOR_B é, estatisticamente, diferente de zero. A_ZFM_C refere-se ao percentual de valor adicionado estimado distribuído aos proprietários pelo grupo total de empresas da Zona Franca de Manaus que contabilizam os incentivos fiscais de forma correta. A_FOR_T refere-se ao percentual de valor adicionado estimado distribuído aos proprietários pelo grupo total de empresas fora da Zona Franca de Manaus. A_FOR_A refere-se ao percentual de valor adicionado estimado distribuído aos proprietários pelas empresas do setor autoindústrias fora da Zona Franca de Manaus. A_FOR_B refere-se ao percentual de valor adicionado estimado distribuído aos proprietários pelas empresas do setor bens de consumo, eletroeletrônico e indústria digital fora da Zona Franca de Manaus.

Foi, ainda, testada, por meio do teste Mann-Whitney para amostras independentes, se a média do valor adicionado distribuído aos proprietários pelo grupo de empresas da ZFM que contabilizam os incentivos fiscais de forma errada (ZFM_E) é igual à média dos demais grupos comparados.

As hipóteses testadas foram:

$\mathrm{H}_{0}: \mu_{\mathrm{A} \_\mathrm{ZFM}} \mathrm{E}=\mu_{\mathrm{A} \_\mathrm{FOR} \_\mathrm{T}}$

$\mathrm{H}_{1}$ : Existe diferença entre as médias.

$\mathrm{H}_{0}: \mu_{\text {A_ZFM_E }}=\mu_{\text {A_FOR_A }}$

$\mathrm{H}_{1}$ : Existe diferença entre as médias.

$\mathrm{H}_{0}: \mu_{\mathrm{A} \_\mathrm{ZFM}} \mathrm{E}=\mu_{\mathrm{A} \_\mathrm{FOR} \_\mathrm{B}}$

$\mathrm{H}_{1}$ : Existe diferença entre as médias. 
Os resultados do teste não paramétrico aplicado constataram que há diferença significativa entre a média de valor adicionado distribuído aos governos do grupo de empresas da ZFM (A_ZFM_E) e os demais grupos com um nível de nível de significância de 5\%, conforme disposto na Tabela 48.

Tabela 48 - Teste de média do valor adicionado distribuído aos proprietários entre o grupo ZFM_E e outros grupos

\begin{tabular}{c|l|c|c|c|c|c}
\hline Grupo & $\begin{array}{c}\text { Grupo } \\
\text { Comparação }\end{array}$ & $\begin{array}{c}\mathbf{N}^{\mathbf{0}} \\
\text { observações }\end{array}$ & $\begin{array}{c}\text { Média } \\
\text { amostral }\end{array}$ & $\begin{array}{c}\text { Estatística } \\
\mathbf{Z}\end{array}$ & $\begin{array}{c}\text { Nível de } \\
\text { significância }\end{array}$ & Resultado \\
\hline A_ZFM_E & & 54 & $-0,0613$ & & & \\
& A_FOR_T & 37 & 0,1835 & $-4,387$ & 0,000 & Rejeita H0 \\
& A_FOR_A & 13 & 0,2367 & $-3,647$ & 0,000 & Rejeita H0 \\
& A_FOR_B & 24 & 0,1546 & $-3,389$ & 0,001 & Rejeita H0 \\
\hline
\end{tabular}

Essa tabela apresenta resultados de teste de amostras independentes que verificou se a média entre A_ZFM_C e A_FOR_T, A_FOR_A e A_FOR_B é, estatisticamente, diferente de zero. A_ZFM_C refere-se ao percentual de valor adicionado estimado distribuído aos proprietários pelo grupo total de empresas da Zona Franca de Manaus que contabilizam os incentivos fiscais de forma errada. A_FOR_T refere-se ao percentual de valor adicionado estimado distribuído aos proprietários pelo grupo total de empresas fora da Zona Franca de Manaus. A FOR A refere-se ao percentual de valor adicionado estimado distribuído aos proprietários pelas empresas do setor autoindústrias fora da Zona Franca de Manaus. A_FOR_B refere-se ao percentual de valor adicionado estimado distribuído aos proprietários pelas empresas do setor bens de consumo, eletroeletrônico e indústria digital fora da Zona Franca de Manaus.

Com relação ao grupo de empresas pares, foi realizado o teste de média para amostras emparelhadas, no qual se busca descobrir se existe diferença entre a média do valor adicionado distribuído aos proprietários do grupo de Empresas da ZFM e a média do grupo de Empresas Pares. Assim, o teste $t$, paramétrico, para médias emparelhadas procura testar as seguintes hipóteses:

$$
\begin{aligned}
& \mathrm{H}_{0}: \mu_{\text {Acio (ZFM - Pares) }}=0 \\
& \mathrm{H}_{1}: \mu_{\text {Acio (ZFM - Pares) }} \neq 0
\end{aligned}
$$

em que:

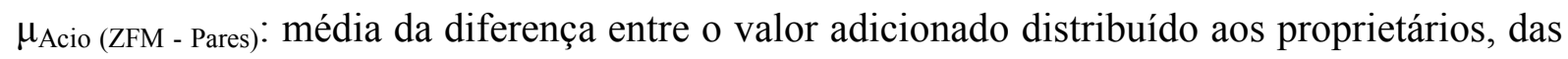
empresas da Zona Franca de Manaus em relação às respectivas empresas pares instaladas fora da ZFM. 
Tabela 49 - Teste de média do valor adicionado distribuído aos proprietários de amostras emparelhadas

\begin{tabular}{lccc}
\hline \multicolumn{1}{c}{ Variáveis } & A_ZFM & A_PARES & A_ZFM - A_PARES \\
\hline Média da amostra & 0,0182 & 0,0644 & $-0,0462$ \\
Desvio-padrão da amostra & 0,2925 & 0,1597 & \\
Diferença máxima & & 0,0339 \\
Diferença mínima & $-0,1264$ \\
Desvio-padrão da diferença & 0,3435 \\
Estatística t & $-1,150$ \\
Nível de significância & 0,254 \\
\hline 73 observações para cada amostra e teste t com 72 graus de liberdade \\
\hline
\end{tabular}

Essa tabela apresenta resultados de teste de amostras emparelhadas que verificou a diferença entre A_ZFM - A_PAR, calculada para cada par de empresas, é, estatisticamente, diferente de zero. A_ZFM refere-se ao percentual de valor adicionado estimado distribuído aos proprietários pelo grupo de empresas da Zona Franca de Manaus. A_PAR refere-se ao percentual de valor adicionado estimado distribuído aos proprietários pelo grupo de empresas fora da Zona Franca de Manaus.

Para as empresas industriais instaladas na ZFM, a média do valor adicionado distribuído aos proprietários é de 1,82\%, enquanto para as empresas pares instaladas fora da ZFM é de 6,44\%. Entretanto, a diferença resultante de 4,62\% que não pode ser interpretada como o valor de riqueza distribuída a mais aos proprietários pelo grupo de empresas instaladas na ZFM, uma vez que não houve a rejeição de $H_{0}$ ao nível de significância de $5 \%(0,254)$, conforme disposto na Tabela 49. Logo, obtém-se a seguinte equação:

$$
\left[\text { Acio }_{\text {ZFM }}-\text { Acio }_{\text {Pares }}\right]=-0,0462
$$

Com os resultados obtidos a partir dos dados constantes dos Apêndices 8, 9, 10, 11 e 14, e apresentados no Quadro 27, a seguir, observa-se o percentual de distribuição de riqueza aos proprietários, pelas empresas, por meio das suas DVAs consolidadas no período de 2003 a 2007. 
Quadro 27 - Distribuição de riqueza aos proprietários das DVAs consolidadas (\%)

\begin{tabular}{|l|c|c|c|c|c|}
\hline \multicolumn{1}{|c|}{ Grupo Empresas } & $\mathbf{2 0 0 3}$ & $\mathbf{2 0 0 4}$ & $\mathbf{2 0 0 5}$ & $\mathbf{2 0 0 6}$ & $\mathbf{2 0 0 7}$ \\
\hline Empresas ZFM & 4,41 & 9,34 & 14,80 & 14,75 & 10,92 \\
Empresas ZFM Corretas & 26,27 & 31,27 & 39,29 & 32,11 & 21,75 \\
Empresas ZFM Erradas & $-9,35$ & $-3,75$ & 2,01 & $-7,68$ & 2,85 \\
Setores Fora ZFM * & 21,03 & 24,01 & 15,99 & 15,74 & 15,68 \\
Empresas Pares & 8,22 & 19,76 & 4,39 & 0,79 & 5,17 \\
\hline
\end{tabular}

* Compreende os setores de autoindústria, bens de consumo, indústria digital e eletroeletrônico

Da análise do Quadro 27, conclui-se que as empresas industriais da ZFM que contabilizam os incentivos fiscais de forma correta e as empresas dos setores fora da ZFM apresentam os maiores percentuais de distribuição de riqueza aos seus proprietários e as empresas da ZFM que contabilizam os incentivos de forma errada evidenciam e divulgam distribuições de riqueza negativas por vários anos (2003, 2004 e 2006) e nos outros dois anos (2005 e 2007) positivos muito baixos. É de se perguntar:

- o que leva os empresários a manter empreendimentos que apresentam distribuição negativa de riqueza?

- $\quad$ se os projetos apresentam prejuízos constantes, estaria a distribuição de riqueza sendo efetivada de outra maneira?

O Gráfico 8, a seguir, permite observar que, ao comparar as empresas da ZFM com as empresas pares, nos anos de 2005, 2006 e 2007, as empresas industriais instaladas na ZFM distribuem uma parcela maior de riqueza aos proprietários do que as empresas pares. 


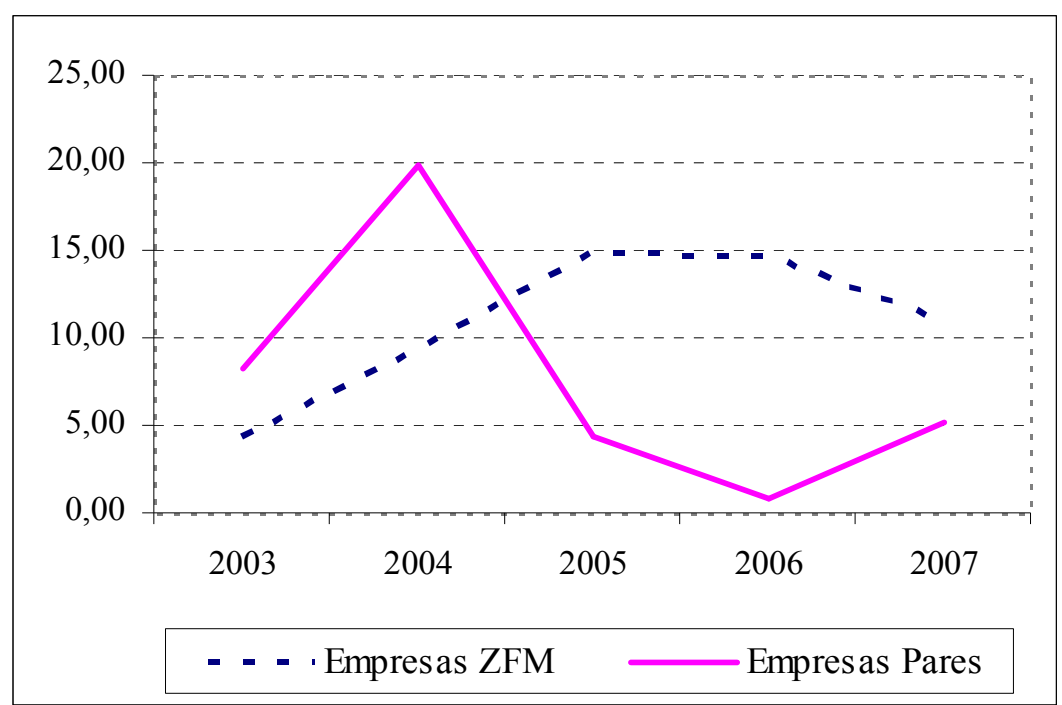

Gráfico 8 - Distribuição de riqueza aos proprietários (\%)

Em resumo, atendendo ao objetivo específico proposto de mensurar a distribuição de riqueza aos proprietários, pelas empresas industriais beneficiárias de incentivos fiscais instaladas na Zona Franca de Manaus, pelo teste de média (1,82\% contra 6,44\%) rejeita-se a hipótese auxiliar 5, ou seja, as empresas industriais instaladas na ZFM distribuem a mesma parcela maior de riqueza aos proprietários e, pelas DVAs reais consolidadas, nos anos 2003 e 2004, as empresas industriais dos mesmos setores ou similares instaladas em outras regiões do País distribuem uma maior parcela de riqueza aos proprietários do que as empresas instaladas na ZFM enquanto nos anos de 2005 a 2007 ocorre o inverso. 



\section{CONSIDERAÇÕES FINAIS}

A Zona Franca de Manaus foi implementada em 1967 com o objetivo de estabelecer um polo de desenvolvimento comercial, industrial e agropecuário, visando a integrar a Amazônia à economia do país, a promover a melhor integração produtiva e social, além de garantir a soberania nacional sobre as fronteiras com países limítrofes.

Trata-se de um instrumento de promoção e desenvolvimento regional com características de uma Zona Econômica Especial na qual se inserem as características de Zona Franca, de Zona de Livre Comércio e de Zona de Processamento de Exportação em decorrência dos incentivos fiscais especiais que contribuíram para a fixação de um polo industrial cujo faturamento no ano de 2007 foi da ordem de US\$28,3 bilhões.

A discussão sobre a concordância e validade dos incentivos fiscais concedidos pelo modelo industrial aos projetos industriais instalados naquela região é uma constante entre os meios empresariais e os governos, embora não sejam numerosos e robustos os estudos que analisam a oportunidade, a viabilidade, a importância e avaliem os incentivos fiscais concedidos pelo modelo ZFM nos seus mais diferentes aspectos. Foi a partir dessa constatação que o presente estudo buscou avaliar os efeitos dos incentivos fiscais na criação e distribuição de riqueza por esse modelo industrial incentivado.

Para isso, foi feita uma discussão teórica sobre as Zonas de Livre Comércio e as Zonas de Processamento de Exportação e a contextualização da Zona Franca de Manaus como instrumento de política industrial, inserida em um conceito macro de políticas de desenvolvimento econômico.

Feita essa discussão sobre o modelo, o trabalho buscou sustentação na teoria sobre comércio exterior, na qual as características da ZFM se correlacionam, e na teoria dos stakeholders, para caracterizar as partes interessadas que se relacionam com a empresa. No contexto dessa última teoria, foi utilizada a Demonstração de Valor Adicionado (DVA) por ser um instrumento contábil que identifica a criação e distribuição de riqueza aos principais agentes que contribuíram para sua geração. 
O objetivo geral traçado para esta tese foi "Avaliar a criação e a distribuição da riqueza gerada pelo modelo industrial Zona Franca de Manaus e confrontá-las com empresas do mesmo setor ou similares localizadas em outras regiões do país." A fim de atender a esse objetivo, foi elaborada a seguinte questão de pesquisa "Quais os efeitos dos incentivos físcais concedidos pela Zona Franca de Manaus às empresas industriais na criação e distribuição da riqueza?"

Para alcançar a resposta da questão de pesquisa, foi formulada a hipótese geral de que os incentivos fiscais concedidos às empresas industriais instaladas na Zona Franca de Manaus possuem efeitos negativos na criação e distribuição de riqueza.

Com a finalidade de alcançar o objetivo principal, foram fixados os objetivos específicos e formuladas cinco hipóteses auxiliares.

O primeiro objetivo específico diz respeito à análise das variáveis de custos que permitem a formação de preço de um produto industrial fabricado com os incentivos fiscais concedidos pelo modelo industrial Zona Franca de Manaus. Por meio dos dados analisados, verificou-se que as principais variáveis de custos que impactam na formação de preço de um produto fabricado na ZFM são a isenção do Imposto sobre Produtos Industrializados (IPI), a redução do Imposto de Importação (II) e a redução, por meio do Crédito Estímulo, do Imposto sobre Circulação de Mercadorias e Serviços (ICMS).

No exemplo analisado, verificou-se que um produto fabricado na ZFM, quando comparado ao mesmo produto fabricado em outro ponto do território nacional, sem incentivos fiscais, é em torno de $20 \%$ mais barato. É de ressaltar que nem todos os produtos apresentam essa mesma margem, entretanto, com uma margem maior ou menor, de acordo com a estrutura de custos do produto ou do setor a que pertence, sempre será produzido a um custo menor em decorrência dos incentivos físcais relativos aos três impostos citados.

Embora outras variáveis, como fretes incidentes sobre a compra de insumos, sobre as vendas dos produtos industrializados e as contribuições condicionadas pela legislação estadual na concessão dos incentivos fiscais referentes ao ICMS possam interferir no preço, não são determinantes na sua formação. 
Outro objetivo específico fixado foi identificar as formas de contabilização dos incentivos fiscais, especificamente, o ICMS, por parte das empresas industriais instaladas na Zona Franca de Manaus. Para isso, foi utilizada a técnica de análise de conteúdo e testada a primeira das hipóteses auxiliares, ou seja, que as empresas industriais, instaladas na Zona Franca de Manaus e beneficiadas com incentivos fiscais, que publicam as demonstrações contábeis, contabilizam os incentivos fiscais de maneira incorreta.

Foram analisadas 150 (cento e cinqüenta) demonstrações contábeis publicadas, no período de 2003 a 2007, pelas empresas industriais beneficiárias dos incentivos fiscais instaladas na ZFM e foram encontradas as seguintes formas de contabilização desses incentivos:

- Forma A: O ICMS é considerado como parte das deduções sobre a Receita Bruta pelo seu valor integral; a parcela referente ao incentivo fiscal é contabilizada como Reserva de Capital - Subvenção para Investimento;

- Forma B: O valor do incentivo fiscal diminui o valor do ICMS constante das deduções da Receita Bruta, já calculados quando da sua apuração;

- Forma C: O ICMS é considerado como parte das deduções sobre a Receita Bruta pelo seu valor integral; a parcela referente ao incentivo fiscal é contabilizada como "Outras Receitas Operacionais";

- $\quad$ Forma D: O ICMS é considerado como parte das deduções sobre a Receita Bruta pelo seu valor integral; não há informações quanto à forma de contabilização do incentivo fiscal.

Pelas razões discutidas ao longo deste trabalho, na parte relativa à caracterização e contabilização dos incentivos fiscais, concluiu-se que a forma correta para a contabilização desses incentivos fiscais é a "B" por ser considerado um incentivo para custeio e não como uma subvenção para investimento. Além do mais, mesmo que o tipo de incentivo concedido pelo modelo industrial ZFM não seja uma subvenção para investimento, se as empresas, assim, o consideram, fica o questionamento da não utilização de tratamento isonômico entre os incentivos decorrentes do imposto sobre produtos industrializados e do imposto de importação. No caso desses dois últimos impostos não há contabilização de qualquer parcela incentivada. 
Essa hipótese auxiliar foi confirmada ao se verificar que $66,67 \%$ das demonstrações contábeis analisadas, no ano de 2007, contabilizam de forma errada. O percentual das empresas que contabilizam da forma "B" foi de $20 \%$, o que, na visão deste trabalho, é a forma correta.

No que diz respeito ao objetivo específico fixado para mensurar a criação de riqueza pelas empresas industriais beneficiárias de incentivos fiscais instaladas na Zona Franca de Manaus foi formulada a hipótese auxiliar de que as empresas industriais, instaladas na Zona Franca de Manaus e beneficiadas com incentivos fiscais, que elaboram ou publicam a Demonstração de Valor Adicionado, criam mais riqueza do que as empresas industriais do mesmo setor ou similares instaladas em outras regiões do país.

Os resultados mostraram que o grupo de empresas industriais incentivadas localizadas na ZFM apresentou os coeficientes de criação de riqueza em função do faturamento de 31,07\%, calculado de acordo com o modelo de regressão da amostra individual, 33,57\%, de acordo com o modelo em que foi utilizada dummy para as empresas pares, 30,96\%, calculado pelo teste de amostras emparelhadas, e 30,88\%, pelo o valor médio obtido das DVAs consolidadas das empresas pertencentes ao grupo, contra 54,36\%, 50,81\%, 45,08\% e 45,71\%, respectivamente, para as empresas pares.

Vale destacar que, ao separar o grupo de empresas industriais instaladas na ZFM que contabilizam os incentivos fiscais de forma incorreta, essas evidenciam e divulgam de forma equivocada, a criação de uma parcela menor de riqueza dos que as que os contabilizam de forma correta, pelo fato de considerarem o valor total do ICMS sobre as vendas enquanto as empresas que contabilizam de forma correta consideram somente o ICMS efetivamente recolhido.

Diante disso, o objetivo específico de mensuração da criação de riqueza foi atendido e a respectiva hipótese auxiliar rejeitada, ou seja, as empresas industriais instaladas na ZFM criam menos riqueza do que as empresas industriais dos mesmos setores ou similares instaladas em outras regiões do País.

O objetivo específico de mensurar a distribuição de riqueza pelas empresas industriais beneficiárias de incentivos fiscais instaladas na Zona Franca de Manaus envolve a análise e mensuração dessa distribuição entre os três principais agentes que contribuíram para a sua 
geração: os empregados, os governos e os proprietários. Para isso, foram formuladas três hipóteses auxiliares, perfazendo o total de cinco, sendo: i) as empresas industriais, instaladas na Zona Franca de Manaus e beneficiadas com incentivos fiscais, que elaboram ou publicam a Demonstração de Valor Adicionado, distribuem uma parcela maior da riqueza aos empregados do que as empresas industriais do mesmo setor ou similares instaladas em outras regiões do país; ii) as empresas industriais, instaladas na Zona Franca de Manaus e beneficiadas com incentivos fiscais, que elaboram ou publicam a Demonstração de Valor Adicionado, distribuem uma parcela menor da riqueza aos governos do que as empresas industriais do mesmo setor ou similares instaladas em outras regiões do país e iii) as empresas industriais, instaladas na Zona Franca de Manaus e beneficiadas com incentivos fiscais, que elaboram ou publicam a Demonstração de Valor Adicionado, distribuem uma parcela maior da riqueza aos proprietários do que as empresas industriais do mesmo setor ou similares instaladas em outras regiões do país.

Os resultados obtidos para a parcela de distribuição de riqueza aos empregados mostraram que as empresas industriais, instaladas na ZFM e beneficiadas com incentivos fiscais, distribuem a parcela de $27,28 \%$, calculada pelo teste de média para amostras emparelhadas, e $17,99 \%$, pelo valor médio obtido das DVAs consolidadas das empresas pertencentes ao grupo, contra $36,31 \%$ e $31,85 \%$, respectivamente, para as empresas pares.

Assim, atende-se ao objetivo específico proposto de mensurar a parcela de riqueza distribuída aos empregados pelas empresas, ao tempo em que se rejeita a hipótese auxiliar de que as empresas industriais instaladas na Zona Franca de Manaus, beneficiadas com incentivos fiscais, que elaboram ou publicam a Demonstração de Valor Adicionado, distribuem uma parcela maior da riqueza aos empregados do que as empresas industriais do mesmo setor ou similares instaladas em outras regiões do país.

Com relação ao objetivo específico de mensurar a parcela de distribuição de riqueza aos governos, os resultados indicaram que as empresas industriais, instaladas na ZFM e beneficiadas com incentivos fiscais, distribuem a parcela de $54,42 \%$, calculada pelo teste de média para amostras emparelhadas, e 54,30\%, pelo valor médio obtido das DVAs consolidadas das empresas pertencentes ao grupo, contra $41,54 \%$ e $43,78 \%$, respectivamente, para as empresas pares. 
Nesse ponto, cabe a ressalva de que, ao considerar somente as empresas industriais instaladas na ZFM e que contabilizam os incentivos fiscais, especificamente o ICMS, de forma correta, a parcela média obtida das DVAs consolidadas reduz para 46,63\% contra 60,03\% evidenciada e divulgada pelas empresas os contabilizam de forma incorreta. Isso faz com que a média do grupo como um todo seja de $54,30 \%$.

Dessa forma, ao satisfazer o objetivo específico proposto de mensurar a parcela de distribuição de riqueza aos governos, foi constatado que as empresas industriais instaladas na Zona Franca de Manaus, beneficiadas com incentivos fiscais, que elaboram ou publicam a Demonstração de Valor Adicionado, distribuem uma parcela maior da riqueza aos governos do que as empresas industriais do mesmo setor ou similares instaladas em outras regiões do país, contrariando a hipótese auxiliar previamente formulada por acreditar que um modelo industrial incentivado destinaria uma parcela menor de riqueza aos governos.

Embora essas conclusões sobre a parcela distribuída aos governos pareçam soar estranhas, deve-se ao fato de que o modelo industrial incentivado Zona Franca de Manaus não propicia incentivos fiscais em relação ao imposto de renda e às contribuições incidentes sobre o faturamento, e, ao mesmo tempo, o ICMS incidente sobre os insumos importados é recolhido no seu desembaraço. Entretanto, ao calcular a riqueza distribuída aos governos em função do faturamento, as empresas instaladas fora da ZFM destinam a parcela de $20,90 \%{ }^{58}$ contra $14,74 \%{ }^{59}$ pelas empresas industriais instaladas na Zona Franca de Manaus.

Da análise do objetivo específico proposto de mensurar a parcela de distribuição de riqueza aos proprietários, conclui-se que as empresas industriais, instaladas na ZFM e beneficiadas com incentivos fiscais, distribuem a parcela de $1,82 \%$, calculada pelo teste de média para amostras emparelhadas, e 10,84\%, pelo valor médio obtido das DVAs consolidadas das empresas pertencentes ao grupo, contra $6,44 \%$ e $7,66 \%$, respectivamente, para as empresas pares.

\footnotetext{
${ }^{58}$ Percentual obtido pela média dos quatro percentuais de criação de riqueza $(54,36 \%, 50,81 \%, 45,08 \%$ e $45,71 \%)$ multiplicada pela média dos dois percentuais de distribuição de riqueza aos governos $(41,54 \%$ e $43,78 \%$ ) encontrados para as empresas pares.

${ }^{59}$ Percentual obtido pela média dos quatro percentuais de criação de riqueza $(31,07 \%, 33,57 \%, 30,96 \%$ e $30,88 \%)$ multiplicado pelo percentual médio de distribuição de riqueza aos governos (46,63\%) encontrados para as empresas industriais instaladas na ZFM, beneficiadas com incentivos fiscais e que os contabilizam de forma correta.
} 
Destaque-se o fato de que as empresas industriais da ZFM que contabilizam os incentivos fiscais de forma correta apresentam parcelas positivas de distribuição de riqueza aos proprietários, com média de 30,14\%, enquanto as empresas que os contabilizam de forma errada evidenciam e divulgam parcelas negativas, com média de $-3,18 \%$. É nesse cenário que fica o questionamento sobre os motivos que levam os empresários a manter empreendimentos que apresentam distribuição negativa de riqueza ou se a distribuição está sendo feita de outra forma.

Diante disso, ao atender ao objetivo específico proposto pelo teste de médias emparelhadas $(1,82 \%$ contra $6,44 \%)$ e pelo valor médio obtido das DVAs consolidadas das empresas $(10,84 \%$ contra $7,66 \%)$, conclui-se que não há diferença significativa da parcela de riqueza que as empresas industriais instaladas na Zona Franca de Manaus e beneficiadas com incentivos fiscais, que elaboram ou publicam a Demonstração de Valor Adicionado, distribuem aos proprietários das empresas industriais do mesmo setor ou similares instaladas em outras regiões do país, rejeitando-se a hipótese auxiliar correspondente.

Os dois últimos objetivos específicos, que são analisar o efeito dos incentivos fiscais sobre a criação e a distribuição de riqueza do modelo industrial Zona Franca de Manaus e a comparação da criação e da distribuição de riqueza gerada pelas indústrias instaladas na Zona Franca de Manaus com setores e indústrias instalados fora da Zona Franca de Manaus, foram atendidos por meio da análise de dados, na qual se conclui que as empresas instaladas na Zona Franca de Manaus criam menos riqueza do que as empresas pares instaladas fora da ZFM e as empresas da ZFM que contabilizam os incentivos fiscais de forma errada evidenciam, de forma equivocada, criação de riqueza maior do que as empresas que contabilizam de forma correta.

Com relação à distribuição de riqueza aos empregados e aos proprietários, as empresas instaladas na Zona Franca de Manaus distribuem uma fatia menor do que as empresas pares instaladas fora e já com relação à distribuição de riqueza aos governos, as empresas instaladas na ZFM distribuem uma parcela maior do que as empresas pares. Destaque-se o fato de que as empresas industriais instaladas na ZFM que contabilizam os incentivos fiscais de forma errata evidenciaram, de forma equivocada, uma fatia maior de riqueza distribuída aos governos do que o grupo das empresas da ZFM como um todo pela influência de o valor do ICMS ser 
considerado pelo total na demonstração de resultados do exercício e, por consequência, na Demonstração de Valor Adicionado.

Ao se realizar a análise apenas com as amostras das empresas instaladas na ZFM com as empresas pares, por meio de outro modelo de regressão e teste de média de amostras emparelhadas, a conclusão permanece a mesma.

Após a análise detalhada de cada objetivo específico e as hipóteses auxiliares serem testadas, conclui-se pelo alcance a contento do objetivo geral por parte deste trabalho de pesquisa, ou seja, foi avaliada a criação e a distribuição da riqueza gerada pelo modelo industrial Zona Franca de Manaus e foram confrontadas com empresas do mesmo setor ou similares localizadas em outras regiões do país.

E, pelos resultados alcançados, foram verificados os efeitos dos incentivos fiscais concedidos pela Zona Franca de Manaus às empresas industriais pelo fato de criar menos riqueza do que os mesmos setores ou similares instalados fora e sem os incentivos fiscais. Diante disso, ficou comprovada a hipótese geral de que os incentivos fiscais concedidos às empresas industriais instaladas na ZFM possuem efeitos negativos na criação de riqueza, na distribuição de riqueza aos empregados e aos proprietários, mas, embora possa parecer um paradoxo, possuem efeitos positivos na parcela distribuída aos governos.

Por fim, como efeito preditivo de valores futuros, a reta de regressão calculada pode ser encarada como uma estimativa da relação real. Logo, ao calcular a riqueza criada por todo o modelo da ZFM, em função do seu faturamento, para o ano de 2007, obtém-se o valor de US\$ 8.785.772 (US\$ 28.277.349 x 0,3107), a US\$ de 31.12.2007.

No que se permite utilizar os dados calculados como proxy para o valor total de riqueza criada pelo modelo industrial ZFM, a distribuição de riqueza aos agentes que ajudaram na sua geração, em função do faturamento total da ZFM, para o ano de 2007, a US\$ de 31.12.2007, são as seguintes parcelas ${ }^{60}$ :

- $\quad$ empregados: US\$ 2.396.759 (US\$ 8.785.772 x 0,2728);

\footnotetext{
${ }^{60}$ Valores calculados de forma exemplificativa utilizando apenas os percentuais de distribuição encontrados no teste de médias de amostras emparelhadas.
} 
- governos: US\$ 4.781.217(US\$ 8.785.772 x 0,5442) e

- $\quad$ proprietários: US\$ 159.901 (US\$ 8.785 .772 x 0,0182).

Embora os resultados obtidos e as conclusões apresentadas sejam muito importantes para o meio acadêmico e científico, deve-se levar em consideração que as conclusões obtidas ficaram restritas à amostra, não podendo ser efetuadas generalizações de seus resultados, uma vez que a amostra é intencional e não probabilística e as variáveis de controle utilizadas na regressão podem ser aumentadas, colocando, assim, novas variáveis para o estudo de suas relações.

Além do mais, dentre as diversas limitações do trabalho, há de se ressaltar o pequeno número de observações e o período estudado de cinco anos. Logo, as conclusões, em hipótese alguma, podem ser generalizadas.

Espera-se que o trabalho tenha contribuído para a constatação de uma necessidade de melhoria das informações contábeis, necessidade de apresentação de relatórios mais transparentes e que a sociedade como um todo exerça a accountability por meio de mecanismos de transparência e de responsabilidade e as políticas industriais passem a ser vistas pela sociedade em geral como parte de uma estratégia de crescimento que está orientado para a expansão de oportunidades para todos e não como brindes para setores já privilegiados da economia.

Ao mesmo tempo, os operadores governamentais ligados, direta e indiretamente, à formulação e concessão dos incentivos fiscais passem a solicitar que as empresas beneficiárias de incentivos fiscais mostrem como a riqueza está sendo criada e distribuída, como forma de prestação de contas à sociedade, uma vez que foi ela quem permitiu o uso dos ativos, de uma forma diferenciada, para a criação de riqueza; passem a apreciar, avaliar e acompanhar o retorno dos incentivos fiscais concedidos.

Espera-se, também, que o trabalho tenha contribuído para mostrar a utilização de um instrumento contábil, no caso a Demonstração de Valor Adicionado, no cálculo de criação e distribuição de riqueza por um modelo industrial incentivado, permitindo, assim, analisar os produtos nacional, regional e setorial, por meio de contribuição do setor para a formação da riqueza nacional e regional; indicação do nível de contribuição da empresa para a formação de 
riqueza do setor, da região; contribuição do produto na formação de riqueza para a região; participação do produto/empresa/setor na utilização de mão de obra local, regional ou nacional; participação do produto/empresa/setor no recolhimento de tributos aos governos federal e estaduais.

O trabalho contribui para a análise de investimentos, concessões de financiamentos e aplicação de subsídios governamentais que levem em consideração a contribuição da empresa à sociedade por meio do recolhimento de tributos aos governos; o nível de utilização da mão de obra; a contribuição da empresa/setor para geração de riqueza na região e que possam ser imprescindíveis na determinação da viabilidade de projetos de investimentos, considerando como indicador que possa ser utilizado na concessão de financiamentos por parte das instituições públicas de financiamento e desenvolvimento e na determinação do nível de subsídios governamentais, quer seja incentivo fiscal ou renúncia fiscal, aos projetos de acordo com o nível da mão de obra utilizada, riqueza criada, tributos a serem recolhidos, dentre outros.

Importa, entretanto, questionar a efetividade do retorno dessa intervenção econômica como forma de política industrial inserida em um processo de promoção de desenvolvimento regional. Ao mesmo tempo, cabe ao gestor de políticas públicas levantar reflexões sobre: Quando os incentivos fiscais acabarem, as empresas estarão preparadas para a continuação ou sobrevivem, apenas, em função dos incentivos fiscais? Até que ponto a região pode sobreviver sem o incentivo fiscal?

Feitas essas ponderações sobre a forma de utilização e contribuição deste trabalho, é de se questionar o papel dos incentivos fiscais concedidos pela Zona Franca de Manaus, uma vez que a política de desenvolvimento não se reduz a incentivos fiscais, nem tampouco à indicação de crescimento do Produto Interno Bruto. Há de existir maior presença da União na região visando ampliar a eficácia das medidas até então implementadas. Falta, assim, aliar o crescimento econômico ao desenvolvimento econômico e social, com o intuito de levar ao contingente populacional, que hoje vive na região de influência socioeconômica da Zona Franca de Manaus, melhores condições de vida. 


\section{REFERÊNCIAS}

ALENCAR, Francisco A. de M. A validade da demonstração do valor adicionado como instrumento de identificação dos efeitos socioeconômicos da política de atração de investimentos através da renúncia fiscal. 2005. Disponível em: $<$ http://www.planejamentotributario.ufc.br/artigos.html $>$. Acesso em: 10/10/2008.

ANDRADE, Rogério Emílio. A política pública do desenvolvimento nacional e a questão da recepção da Zona Franca de Manaus pela Constituição de 1988. In: MARTINS, Ives Gandra da Silva et al. (Coord.). Tributação na Zona Franca de Manaus. São Paulo: MP, 2008.

ANEEL. Despacho n. 4.796, de 24/12/2008. Disponível em: <http:www.cpc.org.br>. Acesso em: 23.01.2009.

AMAZONAS (Estado). Decreto n. 23.994, de 29/12/2003. Disponível em: $<$ http:www.sefaz.am.gov.br>. Acesso em: 14/08/2008.

AMAZONAS (Estado). Lei n. 2.826, de 29/09/2003. Disponível em: $<$ http:www.sefaz.am.gov.br>. Acesso em: 14/08/2008.

ASKREN, Barbara J. et al. The impact of performance plan adoption on value added and earnings. Managerial Finance, 20, n. 9, p. 27-43, 1994.

ATKINSON, Anthony A. et al. Contabilidade gerencial. São Paulo: Atlas, 2000.

BAO, Ben-Hsien; BAO, Da-Hsien. Usefulness of value added and abnormal economic earnings: an empirical examination. Journal of Business Finance \& Accounting, 25 (1), (2), 01-03/1998.

. The times series behavior and predictivity results of annual value added data. Journal of Business Finance \& Accounting, 23 (3), p. 449-460, 04/1996.

BANNISTER, James W.; BELKAOUI, Ahmed R. Value added and corporate control in the U.S. Journal of International Financial Management and Accounting, Autumm, p. 241257. 1991.

BARDIN, Laurence. Análise de Conteúdo. Lisboa: Edições 70, 1977.

BARRAL, Welber. O comércio internacional. Belo Horizonte: Del Rey, 2007.

BARROSO, Yuri Dantas. A Zona Franca de Manaus e seu regime jurídico-tributário. In: MARTINS, Ives Gandra da Silva et al. (Coord.). Tributação na Zona Franca de Manaus. São Paulo: MP, 2008. 
BASTOS, Celso Ribeiro. Incentivos Fiscais - Zona Franca de Manaus - Parecer. Cadernos de direito tributário e finanças públicas, 22/167-83, citação p. 168. São Paulo, Centro de Estudos Tributários, Resenha Tributária, 1998.

BAUMAN, Renato et al.. Economia internacional: teoria e experiência brasileira. São Paulo: Elsevier, 2004.

BELKAOUI, Ahmed R. The new environment in international accounting. New York: Quorum Books, 1988. 1992.

. Value added reporting: lessons for the United States. New York: Quorum Books, . The informational content of value added, earnings and cash flows: U.S. evidence. The International Journal of Accounting, v. 28, n. 2, p. 140-146, 1993.

. The effect of ownership structure on value added performance. Managerial Finance, $\overline{20, \text { n. } 9}$, p. 16-26, 1994a.

. Explaining market returns: earnings versus value added data. Managerial Finance, v. 20, (9), p. 44-55, $1994 b$.

. Earnings-returns versus net value-added returns relation: the case for nonlinear specification. Advances in Quantitative Analysis in Finance and Accounting, n. 4, p. 175$185,1996$.

- Performance plan adoption and performance: the contingency of ownership structure. Finance Management, 23, n. 25, 1997a.

. Multidivisional structure and productivity: the contingency of diversification strategy. Journal of Business Finance \& Accounting, v. 24(5), p. 615-628, 06/1997b.

1999.

.Value added reporting and research: State of the art. New York: Quorum Books,

. Net value added and earnings determination. Review of Quantitative Finance and Accounting, v. 13 (4), p. 393-399, 12/1999.

BELKAOUI, Ahmed R.; FEKRAT, M. Ali. The magic in value added: merits of derived accounting indicators numbers. Managerial Finance, v. 20, (9), p. 3, 1994.

; PICUR, Ronald D. Net value added as an explanatory variable for returns. Managerial Finance, v. 20, (9), p. 56-64, 1994. 
BELOQUE, Guilherme Garcia. Estimativa do prêmio pelo risco país com a aplicação do modelo AEG. São Paulo, 2008. Dissertação (Mestrado em Ciências Contábeis) - Programa de Pós-Graduação em Ciências Contábeis, Departamento de Contabilidade e Atuária da Faculdade de Economia, Administração e Contabilidade da Universidade de São Paulo.

BENTLEY, Trevor. Added value and contribution. Management Accounting, v. 59, n. 3, p. 7-21,03/1981.

BETTIOL JUNIOR et al. Formação e evidenciação do resultado de entidades do terceiro setor: um estudo de caso. In: ENCONTRO ANUAL DA ASSOCIAÇÃO DOS PROGRAMAS DE PÓS-GRADUAÇÃO EM ADMINISTRAÇÃO - EnANPAD, 29., 2005, Brasília. Anais... Brasília: ANPAD, 2005.

BISPO, Jorge de Souza. Pólo industrial exportador: desafios para o novo papel da Zona Franca de Manaus. Rio de Janeiro. 2003. Dissertação (Mestrado) - Escola Brasileira de Administração Pública da Fundação Getúlio Vargas.

BRASIL. Constituição Federal, de 05/10/1988. Disponível em: $<$ http:www.presidencia.gov.br>. Acesso em: 14/08/2008.

. Constituição (1988). Emenda Constitucional n. 33, de 11/12/2001. Disponível em: <http:www.planalto.gov.br>. Acesso em: 14/08/2008.

. Constituição (1988). Emenda Constitucional n. 42, de 19/12/2003. Disponível em: <http:www.suframa.gov.br>. Acesso em: 14/08/2008.

Decreto n. 1.030, de 29/12/1993. Disponível em: <http:www.planalto.gov.br>. Acesso em: 26/08/2008.

Decreto n. 3.000, de 26/03/1999 (RIR). Disponível em: <http:www.receita.fazenda.gov.br>. Acesso em: 26/08/2008.

Decreto n. 4.543, de 26/12/2002 (RA). Disponível em: <http:www.receita.fazenda.gov.br>. Acesso em: 26/08/2008.

Decreto n. 4.544, de 26/12/2002 (RIPI). Disponível em: <http:www.receita.fazenda.gov.br>. Acesso em: 26/08/2008.

Decreto n. 6.759, de 07/02/2009

<http:www.receita.fazenda.gov.br>. Acesso em: 22/02/2009.

(RA). Disponível em:

. Decreto n. 47.754, de 03/02/1960. Disponível em: <http:www.presidencia.gov.br>. Acesso em: 14/08/2008.

Decreto n. 61.244, de 28/08/1967. Disponível em: <http:www.presidencia.gov.br>. Acesso em: 14/08/2008. 
. Decreto-lei n. 288, de 28/02/1967. Disponível em: <http:www.presidencia.gov.br>. Acesso em: 14/08/2008.

. Decreto-lei n. 1.435, de 16/12/1975. Disponível em: <http:www.suframa.gov.br>. Acesso em: 14/08/2008.

. Lei n. 3.173, de 06/06/1957. Disponível em: <http:www.suframa.gov.br>. Acesso em: 14/08/2008.

Lei n. 6.404, de 15/12/1976. Disponível em: $<$ http:www.presidencia.gov.br $>$. Acesso em: $14 / 08 / 2008$.

. Lei n. 8.387, de 30/12/1991. Disponível em: $<$ http:www.presidencia.gov.br $>$. Acesso em: $14 / 08 / 2008$.

. Lei n. 9.044, de 17/05/1995. Disponível em: < http:www.presidencia.gov.br > . Acesso em: $14 / 08 / 2008$.

Lei n. 11.508, de 20/07/2007. Disponível em: <http:www.presidencia.gov.br>. Acesso em: 14/08/2008.

. Lei n. 11.638, de 28/12/2007. Disponível em: <http:www.presidencia.gov.br>. Acesso em: 14/08/2008.

Medida Provisória n. 1858-6, de 29/07/1999. Disponível em:

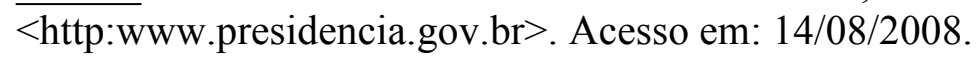

Medida Provisória n. 2037-25, de 28/06/2000. Disponível em: <http:www.presidencia.gov.br>. Acesso em: 14/08/2008.

. Medida Provisória n. 2158-01, de 24/08/2001. Disponível em:

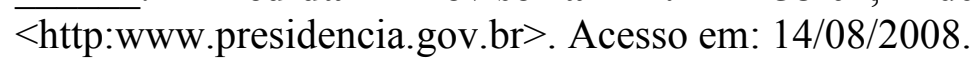

. Projeto de lei n. 1.310, de 15/01/1951. Disponível em: <http:www.senado.gov.br>. Acesso em 14/08/2008.

BRITO MACHADO, Hugo de. A "guerra fiscal". 2000. Disponível em: $<$ http:www.hugomachado.adv.br>. Acesso em: 12/12/2008.

BUSSAB, W. de O.; MORETTIN, Pedro A. Estatística Básica. 5. ed. São Paulo: Saraiva, 2002.

BURCHELL, Stuart et al. Accounting in its social context: towards a history of value added in the United Kingdom. Accounting Organizations and Society, v. 10, n. 4, p. 381-413, 1985. 
BUSINESS Dictionary. Disponível em: $<$ http://www.businessdictionary.com/definition>. Acesso em: 12/12/2008.

CASSIOLATO, José Eduardo. A Economia do conhecimento e as Novas Políticas Industriais e Tecnológicas. In: LASTRES, Helena Maria Martins; ALBAGLI, Sarita (Org.) Informação e globalização na era do conhecimento. Rio de Janeiro: Campus, 1999.

CHAN, Betty Lilian et al.. Distribuição do Valor Adicionado: Comparação entre empresas estatais e privadas do setor de serviços públicos. In: CONGRESSO USP DE CONTROLADORIA E CONTABILIDADE 3., 2003, São Paulo. Anais... São Paulo: USP, 2003.

CAHAN, Steven F.; VAN STADEN, Chris J. Black economic empowerment, legitimacy, and accounting disclosures: evidence from post-apartheid South Africa. Accounting \& Finance, v. 49 , n. 1 , p. $37-58,03 / 2009$.

COELHO, Guiomar. Tributos sobre o comércio exterior. São Paulo: Aduaneiras, 2006.

COEN, Robert M. Effects of tax policy on investment in manufacturing. The American Economic Review, v. 58, n. 2, p. 200-211, 05/1968.

COMISSÃO DE VALORES MOBILIÁRIOS. Deliberação CVM n. 557, de 12/11/2008. Disponível em: <http:www.cvm.gov.br>. Acesso em: 23/11/2008.

COMITÊ DE PRONUnCIAMENTO CONTÁBIL. Pronunciamento Técnico 09, de 20/10/2008. Disponível em: <http:www.cpc.org.br>. Acesso em: 23/11/2008.

CONSELHO DE POLÍTICA FAZENDÁRIA - CONFAZ. Convênio ICM 65/88, de 06.12.1988. Disponível em <http://www.fazenda.gov.br/confaz/confaz/Convenios/ ICMS/1988/CV065_88.htm>. Acesso em: 19/09/2008.

CONSELHO FEDERAL DE CONTABILIDADE. Resolução n. 1.026, de 15/04/2005. Disponível em: <http:www.cfc.org.br>. Acesso em: 28/12/2008.

. Resolução n. 1.055, de 21/11/2008. Disponível em: <http:www.cfc.org.br>. Acesso em: 28/12/2008.

Resolução n. 1.138, de 21/11/2008. Disponível em: <http:www.cfc.org.br>. Acesso em: $28 / 12 / 2008$.

Resolução n. 1.143, de 21/11/2008. Disponível em: <http:www.cfc.org.br>. Acesso em: $28 / 12 / 2008$.

CORRAR, Luiz J.; THEÓPHILO, Carlos Renato. (Coord.) Pesquisa Operacional. São Paulo: Atlas, 2004. 
COSENZA, J. P. et al. A participação dos agentes econômicos no valor adicionado: estudo empírico na indústria siderúrgica brasileira no período 1996/2000. Contabilidade Vista e Revista, v. 13, n. 2, p. 37-65, 2002.

A Eficácia informativa da demonstração do valor adicionado. Revista de

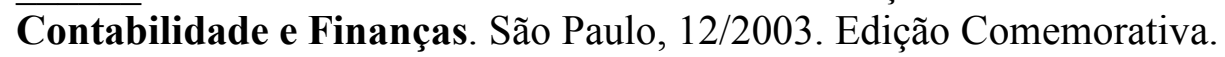

CUNHA, Jaqueline Veneroso Alves. Demonstração contábil do valor adicionado - DVA um instrumento de mensuração da distribuição da riqueza das empresas para os funcionários. São Paulo, 2002. Dissertação (Mestrado em Ciências Contábeis) - Programa de PósGraduação em Ciências Contábeis, Departamento de Contabilidade e Atuária da Faculdade de Economia, Administração e Contabilidade da Universidade de São Paulo.

CUNHA, Jacqueline V. A. et al.. A demonstração do valor adicionado como instrumento de mensuração da distribuição da riqueza. Revista Contabilidade e Finanças. São Paulo, n. 37 p. 7-23, 01-04/2005.

DALMÁCIO, Flávia Zóboli. Indicadores para análise da Demonstração do Valor Adicionado. Revista Brasileira de Contabilidade. Brasília, v.1, n. 1, n. 149, p. 89-97, 07-12/2004,

DEEGAN, Craig. The legitimizing effect of social and environmental disclosures - a theorical foundation. AAAJ - Accounting, Auditing \& Accountability Journal, v. 15, n. 3, p. 282$311,2002$.

DE LUCA, Márcia Martins Mendes. Demonstração do valor adicionado. São Paulo, 1991. Dissertação (Mestrado em Ciências Contábeis) - Programa de Pós-Graduação em Ciências Contábeis, Departamento de Contabilidade e Atuária da Faculdade de Economia, Administração e Contabilidade da Universidade de São Paulo.

A contribuição da demonstração do valor adicionado no processo de mensuração do PIB e em algumas análises macroeconômicas. São Paulo, 1996. Tese (Doutorado em Ciências Contábeis) - Programa de Pós-Graduação em Ciências Contábeis, Departamento de Contabilidade e Atuária da Faculdade de Economia, Administração e Contabilidade da Universidade de São Paulo.

Demonstração do valor adicionado. São Paulo: Atlas, 1998.

DINIZ, Marcelo de Lima Castro; FORTES, Felipe Cianca. Incentivos fiscais no STJ. In: MARTINS, Ives Gandra da Silva et al. (Coord.). Incentivos fiscais: questões pontuais nas esferas federal, estadual e municipal. São Paulo: MP, 2007.

DONALDSON, Thomas; PRESTON, Lee E. The stakeholder theory of the corporation: concepts, evidence, and implications. The Academy of Management Review, v. 20, n. 1, 65$91,01 / 1995$. 
ELALI, André. Incentivos fiscais, neutralidade da tributação e desenvolvimento econômico: a questão da redução das desigualdades regionais e sociais. In: MARTINS, Ives Gandra da Silva et al. (Coord.). Incentivos fiscais: questões pontuais nas esferas federal, estadual e municipal. São Paulo: MP, 2007.

EVRAERT, Serge. Usefulness of value added reporting: a review and synthesis of the literature. Managerial Finance, v. 24, n. 11, p. 1-15, 1998.

FÁVERO, L. P. et al. Análise de dados - modelagem multivariada para tomada de decisões. São Paulo: Campus, 2009.

FREEMAN, R. Edward. Strategic Management. A stakeholder approach. Marshfield, USA: Pitman Publishing Inc. 1984.

et al. Managing for stakeholders. New Haven, USA: Yale University Press, 2007.

FURLAN, Valéria. Fundamentos constitucionais da Zona Franca de Manaus. In: MARTINS, Ives Gandra da Silva et al. (Coord.). Tributação na Zona Franca de Manaus. São Paulo: MP, 2008.

GALLO, Mauro Fernando et al. Mensuração da carga tributária efetiva; existem divergências entre os enfoques econômico e contábil. In: ENCONTRO ANUAL DA ASSOCIAÇÃO DOS PROGRAMAS DE PÓS-GRADUAÇÃO EM ADMINISTRAÇÃO, 30, 2006, Rio de Janeiro. Anais... Rio de Janeiro: ANPAD, 2006.

GALVÃO, Olímpio J. de A. Incentivos fiscais regionais no Brasil: Uma avaliação da sua compatibilidade à luz da OMC. Revista Econômica do Nordeste, v. 30, n. 4, p. 1038-1051, 11-12/1999.

GAZETA MERCANTIL. Fiesp nega espaço para exposição da ZFM em São Paulo. São Paulo, 11/04/2002. Disponível em: $<$ http://indexet.gazetamercantil.com.br/arquivo/2002/04/11>. Acesso em: 15/08/2007.

GIL, Antonio Carlos. Como elaborar projetos de pesquisa. 4. ed. São Paulo: Atlas, 2002.

GRAY, R. Thirty years of Social Accounting, Reporting and Auditing: What (If Anything) Have We Learnt? Business Ethics: A European Review, v. 10, n. 1, p. 9-15, 2001.

GREMAUD, Amaury P. et al. Economia brasileira contemporânea. São Paulo: Atlas, 2007.

GUINET, Jean; KAMATA, Hiroko. Do tax-incentives promote innovation? The OECD Observer, n. 202, p. 22-25, 10-11/1996. 
GUJARATI, Damodar N. Econometria Básica. Tradução. 4. ed. Rio de Janeiro: Elsevier, 2006.

HAMADA, Koichi. An economic analysis of the duty-free zone. Journal of International Economics, v. 4, p. 224-241, 1974.

HAMILTON, Carl; SVENSSON, Lars E.O. On the welfare effects of a "duty-free zone'. Journal of International Economics, v. 13, p. 45-64, 1982.

HANSEN, Don R.; MOWEN, Maryanne M. Gestão de custos contabilidade e controle. São Paulo: Thomson, 2003.

HENDRIKSEN, Eldon S.; BREDA, Michael F. Teoria da contabilidade. São Paulo: Atlas, 1999.

HELLER, H. Robert. Comercio internacional: teoria y evidencia empírica. Madrid: Tecnos, 1970.

HORNGREN, Charles T. et al. Contabilidade de custos. Rio de Janeiro: LTC, 2000.

IBGE. Contas regionais do Brasil 2003-2006. Disponível em <http:www.ibge.gov.br>. Acesso em 18/12/2008.

IGALENS, Jacques; JORAS, Michel. La responsabilité sociale de lénterprise. Paris: Éditions d'Organisation, 2002.

IUDÍCIBUS, Sérgio. Teoria da contabilidade. São Paulo: Atlas, 2004.

2004.

; LOPES, A. Broedel. (Coord.). Teoria avançada da contabilidade. São Paulo: Atlas,

JENKINS, Hatice; JENKINS, Glenn. Incidence of the WTO anti-discrimination rules on corporation income taxation. Queen's Economics Department Working Paper, n. 1123, Canada, 2007.

JONES, Thomas M. Instrumental stakeholder theory: A synthesis of ethics and economics. The Academy of Management Review, Apr 1995, v. 20, n. 2, pp. 404-437.

KARPIK, P.; BELKAOUI, Ahmed R. The relationship between systematic risk and value added variables. Journal of International Financial Management and Accounting. Autumm, p. 259-276, 1989.

KENNEDY, Peter. A guide to econometrics. 5. th. Massachutts: The MIT Press, 2006.

KERLINGER, Fred N. Metodologia da pesquisa em ciências sociais: um tratamento conceitual. São Paulo: EPU, 1980. 
KROETZ, César Eduardo Stevens. Balanço social, teoria e prática. São Paulo: Atlas, 2000.

KRUEGER, Anne O. Trade Policy and Economic Development: How we learn. NBER Working Papers Series. 1997. Disponível em: <http://www.nber.org/papers/w5896.pdf>. Acesso em: 08/12/08.

KRUGMAN, Paul R.; OBSTFELD, Maurice. International economics. 3 ed. New York: HarperCollins, 1994.

Addison Wesley, 2007

. Economia internacional. Teoria e prática. 6. ed. São Paulo: Pearson

KRUGMAN, Paul. The move toward free trade zones. 1991. Disponível em: $<$ http://www.kansascityfed.org/publicat/sympos/1991/S91krugm.pdf>. Acesso em: 1/12/2008.

LASTRES, Helena Maria Martins. A Globalização e o Papel das Políticas de desenvolvimento Industrial e Tecnológico. Texto para discussão n. 519, Brasília, 12/1997. Disponível em: <http://www.ipea.gov.br/pub/td/1997/td_0519.pdf > . Acesso em: 08/07/2007.

LUNA, Sergio V. de. Planejamento de pesquisa: uma introdução. São Paulo: EDUC, 1997.

MAROCO, João. Análise estatística: com utilização do SPSS. Lisboa: Silabo, 2003.

MARTINS, Eliseu. Uma nova demonstração: a do Valor Adicionado. Temática Contábil e Balanços. Boletim IOB 14/93, p. 114.

MARTINS, Eliseu. Uma nova demonstração contábil pleiteada no projeto de reforma da Lei das S.A.: a do valor adicionado. Temática Contábil. Boletim IOB 29/97a, p.4.

. Demonstração do valor adicionado: alguns exemplos reais. Temática Contábil. Boletim IOB 31/97b.

; RIBEIRO, Maisa Souza. A informação como instrumento de contribuição da contabilidade para a compatibilização no desenvolvimento econômico e a preservação do meio ambiente. Cadernos de Estudos FIPECAFI, n. 9, São Paulo, 1993.

MARTINS, Eliseu et al. Manual de contabilidade das sociedades por ações. São Paulo: Editora Atlas, 2007.

MARTINS, Gilberto de A. Manual para elaboração de monografias e dissertações. 3. ed. São Paulo: Atlas, 2002. 
MARTINS, Gilberto de A. Estatística geral e aplicada. 3. ed. São Paulo: Atlas, 2005.

. Estudo de caso uma estratégia de pesquisa. São Paulo: Atlas, 2006.

MARTINS, Gilberto de Andrade; THEÓPHILO, Carlos Renato. Metodologia da investigação científica para ciências sociais aplicadas. São Paulo: Atlas, 2007.

MARTINS, Ives G. Da S. et al. (Coord.) Tributação na zona franca de Manaus. São Paulo: MP, 2008.

MATHEWS, M. R. Socially responsible accounting. London: Chapman \& Hall, 1993.

MATTAR, Fauze N. Pesquisa de marketing. São Paulo: Atlas, 1996.

MEEK, Gary K.; GRAY, Sidney J. The value added statement: an innovation for the U.S. Companies. Accounting Horizons, p. 73-81, 06/1988.

MELO, Fábio Soares de. Incentivos fiscais e segurança jurídica. In: MARTINS, Ives Gandra da Silva et al. (Coord.). Incentivos fiscais: questões pontuais nas esferas federal, estadual e municipal. São Paulo: MP, 2007.

MERINO, A. P.; DIAZ, M. R. A. SPSS 11: Guia para El analisis de datos. Madrid: McGraw Hill, 2002.

MITCHELL, Ronald K. et al. Toward a theory of stakeholder identification and salience: Defining the principle of who and what really counts. The Academy of Management Review, v. 22, n. 4, p. 853-886, 12/1997.

MIYAGIWA, Kaz F. A reconsideration of the welfare economics of a free-trade zone. Journal of International Economics, v. 21, p. 337-350, 1986.

MUÑOZ, Calomina Clara I. El estado contable del valor añadido. Actualidad Financiera, n. 29, Julio 1989, p. 1901-1907.

NAM, Chang Woon; RADULESCU, Doina Maria. Types of tax concessions for attracting foreign direct investment in free economic zones. CESsifo Working paper n. 1175, 04/2004.

NG, Chi-Yung; WHALLEY, John. Geographical extension of free trade zones as trade liberalization: a numerical simulation approach. CESifo Working Paper N. 1147, 1-25, 03/2004.

OLIVEIRA, Marcelle Colares; ALVES, José Flávio Vasconcelos. A evolução da evidenciação da Demonstração do Valor Adicionado no Brasil e a Geração e Distribuição de 
Riqueza por Empresas Brasileiras. In: CONGRESSO USP DE CONTROLADORIA E CONTABILIDADE, 3., 2003, São Paulo. Anais... São Paulo: USP, 2003.

PARMEZZANO, Cláudia Meca. Demonstração do valor adicionado: uma proposta de modelo aplicado às principais seguradoras do Brasil e os resultados obtidos desta pesquisa. São Paulo, 2002. Dissertação (Mestrado em Ciências Contábeis) - Programa de PósGraduação em Ciências Contábeis, Departamento de Contabilidade e Atuária da Faculdade de Economia, Administração e Contabilidade da Universidade de São Paulo.

PAVLIK, Ellen; BELKAOUI, Ahmed R. The effect of ownership structure on value added performance. Managerial Finance, v. 20, n. 9, p. 16-26,1994.

PESTANA, Maria Helena; GAGEIRO, João Nunes. Análise de dados para ciências sociais: a complementaridade do SPSS. 2. ed. Lisboa: Sílabo, 2000.

PICUR, Ronald D. The effects of accounting knowledge on the omission of value added information in wealth measurement and distribution decisions. Review of Accounting and Finance, v. 6, n. 1, p. 15-23, 2007.

PINDYCK, Robert S.; RUBINFELD, Daniel L. Econometria: modelos e previsões. 4. ed. Rio de Janeiro: Campus, 2004.

PIRES, Adilson Rodrigues. Ligeiras reflexões sobre a questão dos incentivos fiscais no Brasil. In: MARTINS, Ives Gandra da Silva et al. (Coord.). Incentivos fiscais: questões pontuais nas esferas federal, estadual e municipal. São Paulo: MP, 2007.

POPPER, Karl Raimund. A lógica da pesquisa científica. 18. ed. São Paulo: Cultrix, 1972.

RECEITA FEDERAL DO BRASIL. Demonstrativo dos gastos tributários 2003/9. Disponível em: $<$ http://www.receita.fazenda.gov.br $>$. Acesso em: 15/12/2008.

Ato Declaratório Executivo COSIT n. 42, 2002. Disponível em: $\overline{<h t t p: / / w w w . r e c e i t a . f a z e n d a . g o v . b r>. ~ A c e s s o ~ e m: ~ 15 / 12 / 2008 . ~}$

Solução de Consulta COSIT n. 6, 2002. Disponível em: $<$ http://www.receita.fazenda.gov.br>. Acesso em: 15/12/2008.

Solução de Divergência COSIT n. 9, 2003. Disponível em:

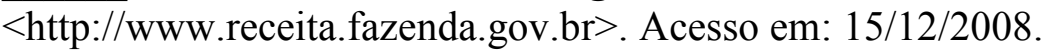

Solução de Divergência COSIT n. 7, 8 e 9, 2006. Disponível em: $\overline{<\mathrm{http}: / / w w w . r e c e i t a . f a z e n d a . g o v . b r>}$. Acesso em: 15/12/2008. 
Ato Declaratório COSIT n. 12, 2007. Disponível em:

$<$ http://www.receita.fazenda.gov.br>. Acesso em: 15/12/2008.

REVISTA VEJA. A Zona Franca de Manaus sobrevive às mudanças. Edição de 03 de setembro de 2003. Disponível em: <http:veja.abril.com/030903/p_096.html>. Acesso em: $15 / 09 / 2007$.

RIBEIRO, M. S.; LISBOA, L. P. Balanço Social. Revista brasileira de Contabilidade, n. 115 , p. 72-81, 01-02/1999.

RIBEIRO, Maísa de Souza; CUNHA, Jacqueline V. A. da. O papel da demonstração do valor adicionado na avaliação da responsabilidade social das empresas. In: CONGRESSO USP DE CONTROLADORIA E CONTABILIDADE, 3., 2003, São Paulo. Anais... São Paulo: USP, 2003.

RIBEIRO, Maria de Fátima. Os 40 anos da Zona Franca de Manaus e a importância dos incentivos fiscais para o desenvolvimento econômico e social da região. In: MARTINS, Ives Gandra da Silva et al. (Coord.). Tributação na Zona Franca de Manaus. São Paulo: MP, 2008.

RIJNVOS, C. J. A new approach of the theory of international trade. Netherlands: Martinus Nijhoff/The Hague, 1976.

RODRIGUES, Fernanda Fernandes et al. Valor adicionado bruto ou valor adicionado líquido: o tratamento da depreciação na demonstração do valor adicionado. In: ENCONTRO ANUAL DA ASSOCIAÇÃO DOS PROGRAMAS DE PÓS-GRADUAÇÃO EM ADMINISTRAÇÃO - EnANPAD, 31., Rio de Janeiro. Anais... Rio de Janeiro: ANPAD, 2007.

RODRIGUES JUNIOR, Manuel Salgueiro. A DVA como instrumento para mensuração da relação custo-benefício na concessão de incentivos fiscais: um estudo de caso. São Paulo, 2003. Dissertação (Mestrado em Ciências Contábeis) - Programa de Pós-Graduação em Ciências Contábeis, Departamento de Contabilidade e Atuária da Faculdade de Economia, Administração e Contabilidade da Universidade de São Paulo.

RODRIGUES, Marilene Talarico Martins. Incentivos fiscais: desenvolvimento econômico e a jurisprudência do STF para o ICMS - "guerra fiscal" entre estados. In: MARTINS, Ives Gandra da Silva et al. (Coord.). Incentivos fiscais: questões pontuais nas esferas federal, estadual e municipal. São Paulo: MP, 2007.

RODRIK, Dani. Industrial policy for the twenty-first century. 11/2004. Disponível em: $<$ http://ksghome.harvard.edu/ drodrik/unidosep.pdf $>$. Acesso em: 15/07/2008.

RUTHERFORD, B. A. Five fallacies about value added. Management Accounting. September, 1981, pp. 31-33.

SANTOS, Ariovaldo dos; CARVALHO, L. Nelson. DVA, uma forma de avaliar a criação de riqueza. Exame - Melhores e Maiores, p. 132-133, 09/1997. 
SANTOS, Ariovaldo dos; LUSTOSA, Paulo Roberto B. Proposta de um modelo de DVA Demonstração do Valor Adicionado - adequado ao novo desenho institucional e mercantil do setor elétrico brasileiro. São Paulo: Fundação Instituto de Pesquisa Econômica - FIPE, 1998.

Demonstração contábil do Valor Adicionado - DVA: um instrumento para medição da geração e distribuição de riqueza das empresas. São Paulo, 1999. Tese (LivreDocência) - Faculdade de Economia, Administração e Contabilidade da Universidade de São Paulo.

SANTOS, Ariovaldo dos. Demonstração do valor adicionado. São Paulo: Atlas, 2003.

; PARMEZZANO, Cláudia Meca. Demonstração do valor adicionado - dois casos muito especiais. Temática Contábil. Boletim IOB 1/99.

; SILVA, Fabiana Lopes da. Aspectos práticos da demonstração do valor adicionado - distribuição de lucros (juros sobre o capital próprio e dividendos) e doações e subvenções para investimento. Temática Contábil. Boletim IOB 15 e 16/2003.

; HASHIMOTO, Hugo. Demonstração do valor adicionado: algumas considerações sobre a carga tributária. Revista de Administração, São Paulo, v. 38, n. 2, p. 153-164, 04-05$06 / 2003$.

DVA - uma demonstração que veio para ficar. Revista Contabilidade e Finanças USP, São Paulo, n. 38, p-3-6, 05-08/2005.

SERÁFICO, José; SERÁFICO, Marcelo. A Zona Franca de Manaus e o capitalismo no Brasil. Estudos Avançados, n. 19 v. 54, p. 99-113, 2005.

SHIN, Jae K.; SIEGEL, Joel G. Modern cost management \& analysis. 2nd ed. NY, USA: Barron's Business Library, 2000.

SILBER, Simão Davi. Teorias do comércio internacional. In: Gestão de negócios internacionais. São Paulo: Saraiva, 2006.

SILVA, Fabiana Lopes da et al. Uma contribuição ao estudo dos impactos da privatização à luz da Demonstração do Valor Adicionado. In: CONGRESSO USP DE CONTROLADORIA E CONTABILIDADE, 3., 2003, São Paulo. Anais... São Paulo: USP, 2003.

SILVA, Mariene Valadares. Política industrial e interesses empresariais: o II PND (19741979). Disponível em: <http://www.abphe.org.br/congresso2003/textos/alphe_2003_64.pdf $>$. Acesso em: 18/11/2008. 
SILVA, Orlando M.; CRUZ JÚNIOR, José C. Dados em Painel: Uma análise do modelo estatístico. In: Econometria aplicada com o uso do Eviews. SOARES, Ilton G.; CASTELAR, Ivan. (Coord). Fortaleza: UFC/CAEN, 2003.

SOUJAnEN, W. Accounting theory and the large corporation. The Accounting Review, v. XXIX, n. 3, p. 391-398, 07/1954.

SOUZA, Nali de Jesus. desenvolvimento econômico. São Paulo: Atlas, 2008.

STEVENSON, William J. Estatística aplicada à administração. São Paulo: Harbra, 1981.

. Estatística aplicada à administração. São Paulo: Harbra, 2001.

STOCK, James H.; WATSON, Mark W. Econometria. São Paulo: Pearson, 2004.

SUFRAMA. Indicadores de desempenho do Polo Industrial de Manaus 2000-2008. Disponível em: <http:www.suframa.gov.br $>$. Acesso em 22/12/2008.

SUPERIOR TRIBUNAL DE JUSTIÇA. Ação Direta de Inconstitucionalidade (ADIn) n. 2.348-9, 2004. Disponível em: <http://ww2.stj.gov.br/SCON/jurisprudencia/toc.jsp >. Acesso em: 19/08/2008.

SUSEP. Circular n. 379, de 19/12/2008. Disponível em <http:www.susep.gov.br>. Acesso em: 02/02/2009.

SUZIGAN, Wilson; FURTADO, João. Política industrial e desenvolvimento. Revista de Economia Política, v. 26, n. 2, p. 163-185, 04-06/2006.

TINOCO, João Eduardo Prudêncio. Balanço Social e a contabilidade no Brasil. Cadernos de Estudos FIPECAFI, n. 9, São Paulo, 1993.

. Balanço Social. São Paulo: Atlas, 2001.

VAN STADEN, Chris J. The usefulness of the value added statement: a review of the literature. Meditari Accountancy Research, v. 16, p. 337-351, 1998.

. The usefulness of the value added statement in South Africa. Managerial Finance, v.

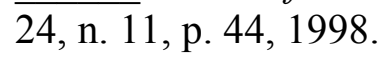

. The value added statement: bastion of social reporting or dinosaur of financial reporting? Massey Discussion Paper n. 200. Mar., 2000. Disponível em: $<$ http://papers.ssrn.com/sol3/papers.cfm?abstract_id=611302>. Acesso em: 16/08/2008. 
. The relevance of theories of political economy to the understanding of financial reporting in South Africa: the case of value added statements. Accounting Forum, v. 27, n. 2, p. 224-245, 06/2003.

VAN STADEN, Chris J. Revisiting the value added statement: social responsibility or social manipulation? Critical Perspectives on accounting Conference at Baruch College: City University of New York, 25-27 April, 2002. Disponível em: $<$ http://aux.zicklin.baruch.cuny.edu/critical/html2/8109staden.html>. Acesso em: 25/08/2006.

VERGARA, S. C. Métodos de pesquisa em administração. São Paulo: Atlas, 2006.

YOSHIOKA, Ricardo. Valor adicionado - alguns conceitos econômicos que ajudam a entender a demonstração contábil. Temática Contábil. Boletim IOB 8/98, p. 1-5.

WATTS, R. L.; ZIMMERMAN, J. L. Towards a positive theory of the determination of accounting standards. The Accounting Review, v. 53, n. 1, p. 112-134, 01/1978.

; __ Positive accounting theory. Englewood Cliffs: Prentice Hall, 1986.

WIKIPEDIA. Disponível em: <http://wikipedia.org.pt>. Acesso em: 12.12.2008.

WOOLDRIDGE, Jeffrey M. Econometric analysis of cross section and panel data. Cambridge: MIT Press, 2002.

WOOLDRIDGE, Jeffrey M. Introdução à econometria. São Paulo: Thompson Learning, 2006. 



\section{GLOSSÁRIO}

ACORDO GERAL SOBRE TARIFAS E COMÉRCIO (GENERAL AGREEMENT ON TARIFFS AND TRADE): É um conjunto de normas e concessões tarifárias, criado com a função de impulsionar a liberalização comercial e combater práticas protecionistas, regular, provisoriamente, as relações comerciais internacionais.

CRÉDITO ESTÍMULO: Valor do incentivo fiscal do ICMS concedido pelo Estado do Amazonas às empresas industriais instaladas na Zona Franca de Manaus, calculado sobre o valor apurado do ICMS a recolher, de acordo com o percentual legal definido para cada linha de produto.

DEMONSTRATIVO DE COEFICIENTE DE REDUÇÃO ELETRÔNICO (DCR-E): Demonstrativo eletrônico que calcula o Coeficiente de Redução do Imposto de Importação, para determinação do pagamento do Imposto de Importação Reduzido a ser pago na internação de produto industrializado na Zona Franca de Manaus.

DECLARAÇÃO DE CONTROLE DE INTERNAÇÃO (DCI): Declaração para Controle de Internação (DCI) para processamento do correspondente despacho de internação de cada operação de saída de mercadorias da ZFM para o restante do território nacional, conforme a respectiva Nota Fiscal.

IMPOSTO DE IMPORTAÇÃO REDUZIDO: Imposto de importação relativo a matériasprimas, produtos intermediários, materiais secundários e de embalagem, componentes e outros insumos de origem estrangeira neles empregados, calculado por meio de um coeficiente de redução de sua alíquota ad valorem, desde que atendam nível de industrialização local compatível com processo produtivo básico, a ser recolhido pela venda de um produto industrializado na Zona Franca de Manaus para outras partes do território nacional.

ÍNDICE DE NACIONALIZAÇÃO: Coeficiente que representa a participação dos componentes nacionais, incluindo a mão de obra direta e os encargos sociais, na composição dos custos dos produtos fabricados na ZFM. Representa o coeficiente de redução variável do imposto de importação obtido mediante a aplicação de fórmula que contenha no dividendo a soma dos valores de matérias primas, produtos intermediários, materiais secundários e de embalagem, componentes e outros insumos de produção nacional, e da mão de obra empregada no processo produtivo e, no divisor, a soma dos valores de matérias primas, produtos intermediários, materiais secundários e de embalagens, componentes e outros insumos de produção nacional e de origem estrangeira, e da mão de obra empregada no processo produtivo.

INTERNAÇÃO: Processo de saída de mercadorias da Zona Franca de Manaus para o restante do País. Significa a entrada no restante do território aduaneiro (todo o território nacional) de mercadoria saída da Zona Franca de Manaus.

INTERNAMENTO: Processo de entrada de mercadorias do restante do País para a Zona Franca de Manaus. 
PROCESSO PRODUTIVO BÁSICO (PPB): Conjunto mínimo de operações a ser seguido pelas empresas fabricantes de produtos industrializados na Zona Franca de Manaus.

PRODUTO INTERNO BRUTO (PIB): Indicador econômico que representa a soma dos valores de todos os bens produzidos dentro de um país, em determinado período, a preços correntes.

PTAX - Taxa de câmbio ponderada de venda/compra de dólar comercial apurada pelo Banco Central do Brasil no final do dia e divulgada no dia seguinte.

RENDA PER CAPTA: Valor resultante da divisão do Produto Interno Bruto a preços correntes pela população total do País; Quantia em reais que cada habitante receberia caso o PIB fosse dividido igualmente entre toda a população.

ZONA DE LIVRE COMÉRCIO (ZLC): São consideradas como sinônimas de Zonas Econômicas Livres (ZEL), assim definidas como aeroporto, porto ou qualquer outra área designada para importação de matérias-primas, componentes, produtos semimontados, semiacabados ou prontos sem o pagamento de tributos. Tais itens podem ser armazenados, demonstrados, montados ou processados para reexportação ou entrar no mercado doméstico do país importador (após o devido pagamento dos tributos).

ZONA DE PROCESSAMENTO DE EXPORTAÇÃO (ZPE): As Zonas de Processamento de Exportação (ZPE) são tipos de Zonas de Livre Comércio criadas pelos governos com o propósito de desenvolvimento dos seus países para promover a indústria e a exportação comercial. Além dos benefícios de uma Zona de Livre Comércio, essas zonas oferecem outros incentivos como isenções de certas taxas e facilidades regulatórias. Conhecidas também como Zonas Econômicas de Desenvolvimento (ZED) ou Zonas Econômicas Especiais (ZEE).

ZONA FRANCA (ZF): São espécies das Zonas de Livre Comércio (ZLC). São designadas por áreas cercadas e controladas nas quais as mercadorias são trazidas sem o pagamento de tributos para posterior processamento ou reexportação 


\section{APÊNDICES}

APÊNDICE 1 - COTAÇÕES MÉDIAS MENSAIS DO DÓLAR COMERCIAL VENDA PTAX - 2003 A 2007.

APÊNDICE 2 - RELAÇÃO DAS MAIORES EMPRESAS DA ZONA FRANCA DE MANAUS POR VOLUME DE VENDAS - 2003 A 2007.

APÊNDICE 3 - FATURAMENTO DAS EMPRESAS DA ZONA FRANCA DE MANAUS QUE PUBLICARAM AS DEMONSTRAÇÕES CONTÁBEIS - 2003 A 2007.

APÊNDICE 4 - PRODUTO INTERNO BRUTO A PREÇOS CORRENTES E PRODUTO INTERNO BRUTO PER CAPITA SEGUNDO AS GRANDES REGIÕES E UNIDADES DA FEDERAÇÃO - 2003 A 2006.

APÊNDICE 5 - PRODUTO INTERNO BRUTO A PREÇOS CORRENTES E PRODUTO INTERNO BRUTO PER CAPITA DAS PRINCIPAIS CIDADES BRASILEIRAS - 2003 A 2006.

APÊNDICE 6 - EMPRESAS QUE APRESENTARAM A DEMONSTRAÇÃO DE VALOR ADICIONADO (DVA) NO ANO DE 2003 A 2007.

APÊNDICE 7 - EMPRESAS PARES 2003 A 2007.

APÊNDICE 8 - DVA CONSOLIDADA DAS EMPRESAS DA ZONA FRANCA DE MANAUS - 2003 A 2007.

APÊNDICE 9 - DVA CONSOLIDADA DAS EMPRESAS DA ZONA FRANCA DE MANAUS QUE CONTABILIZAM OS INCENTIVOS DE FORMA CORRETA - 2003 A 2007.

APÊNDICE 10 - DVA CONSOLIDADA DAS EMPRESAS DA ZONA FRANCA DE MANAUS QUE CONTABILIZAM OS INCENTIVOS DE FORMA ERRADA - 2003 A 2007.

APÊNDICE 11 - DVA CONSOLIDADA DAS EMPRESAS FORA DA ZONA FRANCA DE MANAUS - TOTAL - 2003 A 2007.

APÊNDICE 12 - DVA CONSOLIDADA DAS EMPRESAS FORA DA ZONA FRANCA DE MANAUS - SETOR AUTOINDÚSTRIA - 2003 A 2007.

APÊNDICE 13 - DVA CONSOLIDADA DAS EMPRESAS FORA DA ZONA FRANCA DE MANAUS - SETOR BENS DE CONSUMO, INDÚSTRIA DIGITAL E ELETROELETRÔNICO - 2003 A 2007.

APÊNDICE 14 - DVA CONSOLIDADA DAS EMPRESAS PARES - 2003 A 2007. 

APÊNDICE 1 - COTAÇÕES MÉDIAS MENSAIS DO DÓLAR COMERCIAL VENDA PTAX - 2003 - 2007.

\begin{tabular}{l|c|c|c|c|c}
\hline \multicolumn{1}{c|}{ Meses } & $\mathbf{2 0 0 3}$ & $\mathbf{2 0 0 4}$ & $\mathbf{2 0 0 5}$ & $\mathbf{2 0 0 6}$ & $\mathbf{2 0 0 7}$ \\
\hline Janeiro & 3,4384 & 2,8518 & 2,6930 & 2,2739 & 2,1385 \\
Fevereiro & 3,5908 & 2,9303 & 2,5978 & 2,1619 & 2,0963 \\
Março & 3,4469 & 2,9055 & 2,7047 & 2,1520 & 2,0897 \\
Abril & 3,1187 & 2,9060 & 2,5792 & 2,1293 & 2,0320 \\
Maio & 2,9557 & 3,1004 & 2,4528 & 2,1781 & 1,9816 \\
Junho & 2,8832 & 3,1291 & 2,4135 & 2,2483 & 1,9319 \\
Julho & 2,8798 & 3,0368 & 2,3735 & 2,1893 & 1,8828 \\
Agosto & 3,0025 & 3,0029 & 2,3606 & 2,1559 & 1,9660 \\
Setembro & 2,9228 & 2,8911 & 2,2944 & 2,1687 & 1,8996 \\
Outubro & 2,8615 & 2,8529 & 2,2565 & 2,1483 & 1,8010 \\
Novembro & 2,9138 & 2,7960 & 2,2108 & 2,1579 & 1,7699 \\
Dezembro & 2,9253 & 2,7182 & 2,2855 & 2,1499 & 1,7860 \\
\hline Média Anual & $\mathbf{3 , 0 7 8 3}$ & $\mathbf{2 , 9 2 6 8}$ & $\mathbf{2 , 4 3 5 2}$ & $\mathbf{2 , 1 7 6 1}$ & $\mathbf{1 , 9 4 7 9}$ \\
\hline
\end{tabular}

Fonte: Suframa 

APÊNDICE 2 - RELAÇÃO DAS MAIORES EMPRESAS DA ZONA FRANCA DE MANAUS POR VOLUME DE VENDAS - 2003

\begin{tabular}{|c|c|c|c|}
\hline N. & Nome Fantasia & Nota & Vendas \\
\hline 1 & Nokia & 2 & 3.218 .113 \\
\hline 2 & Moto Honda & 2 & 2.221 .536 \\
\hline 4 & Samsung & 3,6 & 1.038 .112 \\
\hline 5 & Samsung SDI & 1 & 1.038 .101 \\
\hline 6 & Philips da Amazônia & 1 & 880.295 \\
\hline 8 & Itautec Philco & 3,6 & 797.194 \\
\hline 9 & LG-AZ & 2,6 & 714.578 \\
\hline 10 & Semp Toshiba AM & 2,6 & 656.762 \\
\hline 11 & Gillette & 2 & 613.240 \\
\hline 12 & LG Philips Displays & 1 & 610.817 \\
\hline 13 & Siemens Eletroeletrônica & $3,6,7$ & 596.174 \\
\hline 14 & Videolar & 2,6 & 570.982 \\
\hline 15 & Sony & 2 & 538.278 \\
\hline 16 & Panasonic & 2,6 & 508.181 \\
\hline 17 & CCE da Amazônia & 2,6 & 475.600 \\
\hline 18 & Gradiente Eletrônica & 3,6 & 386.344 \\
\hline 19 & Arosuco & 2,6 & 301.344 \\
\hline 20 & Brastemp AM & 2,6 & 253.447 \\
\hline 21 & Fuji Photo & 3,6 & 212.135 \\
\hline 22 & Procomp Amazônia & 2,6 & 185.020 \\
\hline 23 & Evadin Amazônia & 3,6 & 177.751 \\
\hline 24 & Bic AM & 3,6 & 167.519 \\
\hline 25 & Showa & 3,6 & 144.339 \\
\hline 26 & Itautinga & 3,6 & 112.660 \\
\hline 27 & Caloi Norte & 2,6 & 105.180 \\
\hline 28 & Sundown Bike,Fitness e Motos & 2,6 & 104.220 \\
\hline 29 & Compaz & 2,6 & 101.527 \\
\hline 30 & Visteon & 3,6 & 98.739 \\
\hline 31 & Multibrás da Amazônia & 2,6 & 91.817 \\
\hline 32 & Taboca & 2,6 & 88.952 \\
\hline 33 & Technos AM & 4 & 79.780 \\
\hline 34 & Sonopress Rimo & 3,6 & 77.266 \\
\hline 35 & Thomson Multímidia AM & 3,6 & 72.003 \\
\hline 36 & Sanyo & 3,6 & 58.387 \\
\hline 37 & Dumont Saab & 3,6 & 47.387 \\
\hline 38 & Cisper Am & 3,6 & 45.009 \\
\hline 39 & Emtec & 2,6 & 42.899 \\
\hline 40 & Pastore & 3,6 & 38.897 \\
\hline 41 & Magnum Am & 3,6 & 32.839 \\
\hline 42 & Rigesa Manaus & 2,6 & 32.177 \\
\hline 43 & Seculus AM & 3,6 & 31.344 \\
\hline \multicolumn{3}{|l|}{ Total } & 17.566.945 \\
\hline
\end{tabular}

Fonte: Fipecafi. Melhores e Maiores

1. Vendas estimadas pela Revista MM. 2. Vendas informadas por meio de questionário. 3. Vendas extraídas da demonstração contábil. 4. Vendas em moeda constante. 6. Informações ajustadas e calculadas pela Revista. 7. Data do balanço diferente de 31.12 . 


\section{APÊNDICE 2 - RELAÇÃO DAS MAIORES EMPRESAS DA ZONA FRANCA DE MANAUS POR VOLUME DE VENDAS - 2004}

\begin{tabular}{|c|c|c|c|}
\hline N. & Nome Fantasia & Nota & Vendas \\
\hline$\overline{1}$ & Nokia & 2 & 2.935 .290 \\
\hline 2 & Moto Honda & 1 & 2.269 .169 \\
\hline 3 & Samsung & 3,6 & 1.332 .380 \\
\hline 4 & Siemens Eletroeletrônica & $3,6,7$ & 1.186 .700 \\
\hline 5 & Itautec Philco & 3,6 & 933.140 \\
\hline 6 & LG-AZ & 2,6 & 910.481 \\
\hline 7 & Philips da Amazônia & 1 & 894.884 \\
\hline 8 & Semp Toshiba AM & 2 & 854.473 \\
\hline 9 & Videolar & 2,6 & 768.830 \\
\hline 10 & Sony & 1 & 746.652 \\
\hline 11 & Gradiente & 2,6 & 729.790 \\
\hline 12 & Samsung SDI & 3 & 678.630 \\
\hline 13 & LG Philips Displays & 1 & 626.418 \\
\hline 14 & Panasonic AM & 2,6 & 557.217 \\
\hline 15 & Gillette & 1 & 549.714 \\
\hline 16 & CCE da Amazônia & 2,6 & 529.310 \\
\hline 17 & Arosuco & 2,6 & 335.481 \\
\hline 18 & Bic AM & 3,6 & 220.547 \\
\hline 19 & CCE & 3,6 & 209.440 \\
\hline 20 & Brastemp da Amazônia & 2,6 & 208.040 \\
\hline 21 & Evadin Amazônia & 3,6 & 205.820 \\
\hline 22 & Procomp Amazônia & 2,6 & 195.496 \\
\hline 23 & Fuji Photo & 3,6 & 181.608 \\
\hline 24 & Showa & 3,6 & 157.547 \\
\hline 25 & Engepack - AM & 2 & 149.260 \\
\hline 26 & Injepet AM & 3,6 & 144.381 \\
\hline 27 & Caloi Norte & 2,6 & 120.247 \\
\hline 28 & Sundown Bike,Fitnes e Motos & 2,6 & 117.618 \\
\hline 29 & Denso industrial da Amazonia Ltda & 3 & 115.590 \\
\hline 30 & PST Indústria Eletrônica da Amâzoni & 1 & 113.468 \\
\hline 31 & Multibrás da Amazônia & 2,6 & 113.313 \\
\hline 32 & CGE - Ceará & 3,6 & 111.458 \\
\hline 33 & Thomson Multímidia AM & 3,6 & 110.232 \\
\hline 34 & Visteon - AM & 3,6 & 106.783 \\
\hline 35 & Itautinga & 3,6 & 100.648 \\
\hline 36 & Taboca & 3,6 & 92.605 \\
\hline 37 & Emtec & 2,6 & 91.945 \\
\hline 38 & Technos AM & 4 & 85.524 \\
\hline 39 & Sonopress Rimo & 3,6 & 76.116 \\
\hline 40 & Musashi & 3,6 & 70.099 \\
\hline 41 & Pastore & 3,6 & 67.643 \\
\hline 42 & Sanyo & 3,6 & 66.298 \\
\hline 43 & Dumont Saab & 3,6 & 40.736 \\
\hline 44 & Rigesa Manaus & 2,6 & 38.530 \\
\hline 45 & Cisper Am & 3,6 & 35.938 \\
\hline 46 & Seculus AM & 3,6 & 34.162 \\
\hline 47 & Tec Toy & 2,6 & 33.791 \\
\hline \multicolumn{3}{|l|}{ Total } & 20.253 .442 \\
\hline
\end{tabular}

Fonte: Fipecafi. Melhores e Maiores

1. Vendas estimadas pela Revista MM. 2. Vendas informadas por meio de questionário. 3. Vendas extraídas da demonstração contábil. 4. Vendas em moeda constante. 6. Informações ajustadas e calculadas pela Revista. 7. Data do balanço diferente de 31.12 . 
APÊNDICE 2 - RELAÇÃO DAS MAIORES EMPRESAS ZONA FRANCA DE MANAUS POR VOLUME DE VENDAS - 2005

\begin{tabular}{|c|c|c|c|}
\hline $\mathbf{N}$. & Nome Fantasia & Nota & Vendas \\
\hline 1 & Moto Honda & 2 & 3.211 .153 \\
\hline 2 & Nokia & 1 & 2.754 .950 \\
\hline 3 & Samsung & 2 & 1.925 .077 \\
\hline 4 & Siemens Eletroeletrônica & $3,6,7$ & 1.507 .223 \\
\hline 5 & LG & 2,6 & 1.079 .058 \\
\hline 6 & Gradiente & 2,6 & 927.875 \\
\hline 7 & Semp Toshiba - AM & 2,6 & 883.567 \\
\hline 8 & Videolar & 2,6 & 823.900 \\
\hline 9 & Philips da Amazônia & 1 & 821.430 \\
\hline 10 & Sony Brasil & 2 & 683.927 \\
\hline 11 & Samsung SDI & 3,6 & 634.111 \\
\hline 12 & Panasonic AM & 3,6 & 585.079 \\
\hline 13 & CCE da Amazônia & 2,6 & 582.314 \\
\hline 14 & Gillette & 1 & 568.684 \\
\hline 15 & LG Philips Displays & 2 & 496.751 \\
\hline 16 & Arosuco & 2,6 & 384.144 \\
\hline 17 & Microservice AM & 2 & 379.968 \\
\hline 18 & Diebold Procomp-AM & 2,6 & 262.285 \\
\hline 19 & Bic AM & 3,6 & 245.327 \\
\hline 20 & Brastemp da Amazônia & 2,6 & 236.107 \\
\hline 21 & Evadin Amazônia & 3,6 & 233.502 \\
\hline 22 & Sundown & 2,6 & 181.845 \\
\hline 23 & Showa & 3,6 & 180.372 \\
\hline 24 & Fuji Photo & 3,6 & 161.870 \\
\hline 25 & $\mathrm{CCE}$ & 3,6 & 152.690 \\
\hline 26 & Vivara & 3,6 & 141.946 \\
\hline 27 & Sonopress Rimo & 3,6 & 132.845 \\
\hline 28 & Denso industrial da Amazonia Ltda & 3,6 & 131.112 \\
\hline 29 & Flextronics & 2,6 & 122.564 \\
\hline 30 & CGE - Ceará & 3,6 & 119.402 \\
\hline 31 & Pósitron & 2 & 118.463 \\
\hline 32 & Thomson Multímidia AM & 3,6 & 113.357 \\
\hline 33 & Caloi Norte & 2,6 & 106.730 \\
\hline 34 & Visteon - AM & 3,6 & 104.230 \\
\hline 35 & Cervejaria Miranda Corrêa & 3 & 103.860 \\
\hline 36 & Pioneer do Brasil Ltda & 3 & 99.273 \\
\hline 37 & Compaz & 2,6 & 89.178 \\
\hline 38 & Technos AM & 4 & 84.736 \\
\hline 39 & Emtec & 3,6 & 84.221 \\
\hline 40 & Pastore & 3,6 & 73.934 \\
\hline 41 & Sanyo & 3,6 & 59.593 \\
\hline 42 & Rigesa da Amazônia & 2,6 & 41.518 \\
\hline 43 & Seculus AM & 2,6 & 40.563 \\
\hline 44 & Dumont Saab & 3,6 & 39.266 \\
\hline 45 & Tec Toy & 2,6 & 36.803 \\
\hline 46 & Orsa Embalagens AM & 3 & 35.141 \\
\hline 47 & Trópico & 2,6 & 33.935 \\
\hline 48 & CNA & 3,6 & 32.788 \\
\hline \multicolumn{3}{|l|}{ Total } & 21.848 .667 \\
\hline
\end{tabular}

Fonte: Fipecafi. Melhores e Maiores

1. Vendas estimadas pela Revista MM. 2. Vendas informadas por meio de questionário. 3. Vendas extraídas da demonstração contábil. 4. Vendas em moeda constante. 6. Informações ajustadas e calculadas pela Revista. 7. Data do balanço diferente de 31.12 . 


\section{APÊNDICE 2 - RELAÇÃO DAS MAIORES EMPRESAS DA ZONA FRANCA DE MANAUS POR VOLUME DE VENDAS - 2006}

\begin{tabular}{|c|c|c|c|}
\hline N. & Nome Fantasia & Nota & Vendas \\
\hline$\overline{1}$ & Moto Honda & 2 & 3.915 .157 \\
\hline 2 & Nokia & 1 & 2.300 .839 \\
\hline 3 & Samsung & 1 & 1.710 .083 \\
\hline 4 & LG-AM & 3,6 & 1.160 .130 \\
\hline 5 & Gradiente & 3,6 & 1.130 .798 \\
\hline 6 & Semp Toshiba-AM & 2,6 & 992.964 \\
\hline 7 & Videolar & 2,6 & 864.841 \\
\hline 8 & Panasonic & 1 & 765.749 \\
\hline 9 & Philips da Amazônia & 1 & 715.126 \\
\hline 10 & CCE-AM & 2,6 & 648.623 \\
\hline 11 & Sony Brasil & 1 & 609.411 \\
\hline 12 & Samsung SDI & 3,6 & 487.087 \\
\hline 13 & LG.Philips & 1 & 435.294 \\
\hline 14 & Siemens Eletroeletrônica & $3,6,7$ & 431.434 \\
\hline 15 & Arosuco & 2,6 & 395.269 \\
\hline 16 & Cervejaria Miranda Corrêa & 2,6 & 256.038 \\
\hline 17 & Bic-AM & 3,6 & 254.686 \\
\hline 18 & Sundown & 2,6 & 250.194 \\
\hline 19 & Brastemp da Amazônia & 2,6 & 218.682 \\
\hline 20 & Showa & 3,6 & 207.099 \\
\hline 21 & Diebold Procomp-AM & 2,6 & 202.073 \\
\hline 22 & Sonopress Rimo & 3,6 & 196.238 \\
\hline 23 & Vivara & 3,6 & 180.146 \\
\hline 24 & Placibras & 2 & 176.713 \\
\hline 25 & Thomson Multímidia-AM & 3,6 & 166.612 \\
\hline 26 & Digibras & 3,6 & 147.922 \\
\hline 27 & Taboca & 1,6 & 146.340 \\
\hline 28 & Pósitron & 3,6 & 145.619 \\
\hline 29 & Pioneer do Brasil Ltda & 2,6 & 128.243 \\
\hline 30 & Masa - AM & 2,6 & 121.167 \\
\hline 31 & CGE - Ceará & 3,6 & 107.222 \\
\hline 32 & Compaz & 2,6 & 104.900 \\
\hline 33 & Caloi Norte & 2,6 & 92.341 \\
\hline 34 & Technos AM & 2 & 88.564 \\
\hline 35 & Pastore & 2,6 & 71.256 \\
\hline 36 & Seculus AM & 2,6 & 43.164 \\
\hline 37 & Rigesa da Amazônia & 3,6 & 43.122 \\
\hline 38 & Dumont Saab & 3,6 & 38.114 \\
\hline 39 & Orsa Embalagens AM & 3,6 & 36.039 \\
\hline \multicolumn{3}{|l|}{ Total } & 19.985.299 \\
\hline
\end{tabular}

Fonte: Fipecafi. Melhores e Maiores

1. Vendas estimadas pela Revista MM. 2. Vendas informadas por meio de questionário. 3. Vendas extraídas da demonstração contábil. 4. Vendas em moeda constante. 6. Informações ajustadas e calculadas pela Revista. 7. Data do balanço diferente de 31.12 . 


\section{APÊNDICE 2 - RELAÇÃO DAS MAIORES EMPRESAS DA ZONA FRANCA DE MANAUS POR VOLUME DE VENDAS - 2007}

\begin{tabular}{|c|c|c|c|}
\hline N. & Nome Fantasia & Nota & Vendas \\
\hline$\overline{1}$ & Moto Honda & 2 & 4.551 .965 \\
\hline 2 & Samsung & 2 & 2.373 .614 \\
\hline 3 & Nokia do Brasil & 1 & 1.942 .956 \\
\hline 4 & LG-AM & 3,6 & 1.377 .139 \\
\hline 5 & Procter \& Gamble do Brasil & 2,6 & 1.122 .029 \\
\hline 6 & Semp Toshiba-AM & 2,6 & 786.568 \\
\hline 7 & Videolar & 2,6 & 715.431 \\
\hline 8 & Philips da Amazônia & 1 & 664.867 \\
\hline 9 & Panasonic & 1 & 640.765 \\
\hline 10 & Sony Brasil & 1 & 563.950 \\
\hline 11 & Gradiente & 1 & 534.268 \\
\hline 12 & CCE-AM & 2,6 & 525.626 \\
\hline 13 & Samsung SDI & 1 & 451.160 \\
\hline 14 & Arosuco & 1 & 448.836 \\
\hline 15 & LG.Philips & 1 & 403.669 \\
\hline 16 & Siemens Eletroeletrônica & 1,7 & 397.733 \\
\hline 17 & Digibras & 2,6 & 375.306 \\
\hline 18 & Crown & 3,6 & 335.963 \\
\hline 19 & Sundown & 2,6 & 312.167 \\
\hline 20 & Brastemp da Amazônia & 2,6 & 266.844 \\
\hline 21 & Vivara & 3,6 & 263.174 \\
\hline 22 & Bic-AM & 3,6 & 224.529 \\
\hline 23 & Thomson Multímidia-AM & 2,6 & 223.078 \\
\hline 24 & Diebold Procomp-AM & 2,6 & 221.773 \\
\hline 25 & Showa & 1 & 213.707 \\
\hline 26 & Placibras & 2,6 & 208.622 \\
\hline 27 & Pósitron & 3,6 & 175.853 \\
\hline 28 & Mercantil Nova Era & 3 & 165.852 \\
\hline 29 & Pioneer & 1,6 & 149.894 \\
\hline 30 & Taboca & 2,6 & 130.356 \\
\hline 31 & Engepack - AM & 3 & 125.633 \\
\hline 32 & Compaz & 2,6 & 103.136 \\
\hline 33 & Caloi Norte & 3,6 & 98.309 \\
\hline 34 & Technos AM & 4 & 91.489 \\
\hline 35 & Masa - AM & 3,6 & 88.502 \\
\hline 36 & Seculus da Amazônia S.A. & 2,6 & 69.628 \\
\hline 37 & Dumont Saab & 3,6 & 45.568 \\
\hline 38 & Rigesa da Amazônia & 2,6 & 38.863 \\
\hline 39 & Cookson Electronics & 3,6 & 36.390 \\
\hline \multicolumn{3}{|l|}{ Total } & 21.465 .212 \\
\hline
\end{tabular}

Fonte: Fipecafi. Melhores e Maiores

1. Vendas estimadas pela Revista MM. 2. Vendas informadas por meio de questionário. 3. Vendas extraídas da demonstração contábil. 4. Vendas em moeda constante. 6. Informações ajustadas e calculadas pela Revista. 7. Data do balanço diferente de 31.12 . 



\section{APÊNDICE 3 - FATURAMENTO DAS EMPRESAS DA ZONA FRANCA DE MANAUS QUE PUBLICARAM AS DEMONSTRAÇÕES CONTÁBEIS - 2003}

\begin{tabular}{|c|c|c|}
\hline N. & Razão social & Faturamento Bruto \\
\hline 1 & Águas do Amazonas S.A. & 76.945 \\
\hline 2 & Arosuco Aromas e Sucos Ltda & 301.344 \\
\hline 3 & Bic Amazônia S/A & 167.519 \\
\hline 4 & Brastemp da Amazônia S.A. & 253.447 \\
\hline 5 & Caloi Norte S.A. & 105.180 \\
\hline 6 & CCE da Amazônia S.A. & 475.600 \\
\hline 7 & Cia. de Navegação da Amazônia & 23.072 \\
\hline 8 & Cisper da Amazônia S/A. & 45.009 \\
\hline 9 & Combras Comércio e Indústria do Brasil S/A & 1.633 \\
\hline 10 & Companhia Brasileira de Bicicletas & 104.220 \\
\hline 11 & Companhia de Saneamento Amazonas & 1.708 \\
\hline 12 & Compaz Componentes da Amazônia S/A & 101.527 \\
\hline 13 & Confederação Brasileira de Atletismo & 5.638 \\
\hline 14 & Cookson Electronics Amazônia Ltda & 15.334 \\
\hline 15 & Copag da Amazônia & 26.942 \\
\hline 16 & Dumont Saab do Brasil S.A. & 47.387 \\
\hline 17 & Emtec da Amazônia S.A. & 42.899 \\
\hline 18 & Evadin Indústrias Amazônia S.A. & 177.751 \\
\hline 19 & Fuji Photo Film da Amazônia Ltda. & 212.135 \\
\hline 20 & Gradiente Eletrônica S.A. & 386.344 \\
\hline 21 & Hermasa Navegação da Amazônia S/A. & 68.395 \\
\hline 22 & Itautec Philco S.A. & 797.194 \\
\hline 23 & Itautinga Agro-Industrial S.A. & 112.660 \\
\hline 24 & Lg Eletrocnics da Amazonia Ltda & 714.578 \\
\hline 25 & Magnum Indústria da Amazônia S.A. & 32.839 \\
\hline 26 & Manaus Energia S/A & 1.229 .732 \\
\hline 27 & Mineração Taboca S.A. & 88.952 \\
\hline 28 & Monark da Amazônia S.A. & 8.244 \\
\hline 29 & Multibrás da Amazônia S.A. & 91.817 \\
\hline 30 & Murata Amazônia Indústria e Comércio LTDA & 14.076 \\
\hline 31 & Musashi da Amazônia Ltda & 29.928 \\
\hline 32 & Panasonic da Amazônia S.A. & 508.181 \\
\hline 33 & Pastore da Amazônia S.A. & 38.897 \\
\hline 34 & Petróleo Sabbá S.A. & 814.270 \\
\hline 35 & Procomp Amazônia Indústria Eletrônica Ltda. & 185.020 \\
\hline 36 & Prodam Processamento de Dados Amazonas SA & 17.044 \\
\hline 37 & Quartz Eletron Indústria e Comércio S/A. & 21.373 \\
\hline 38 & Refrima S.A. Epuipamentos Industriais & 2.845 \\
\hline 39 & Rigesa da Amazônia S.A. & 32.177 \\
\hline 40 & Samsung Eletrônica da Amazônia Ltda & 1.038 .112 \\
\hline 41 & Sanyo da Amazônia S.A. & 58.387 \\
\hline 42 & Seculus da Amazônia S.A. Jóias Relógios & 31.344 \\
\hline 43 & Semp Toshiba Amazonas S.A. & 656.762 \\
\hline 44 & Showa do Brasil Ltda & 144.339 \\
\hline 45 & Siemens Eletroeletrônica S.A. & 596.174 \\
\hline 46 & Sonopress Rimo AM Ind. Com. Fonog. LTDA & 77.266 \\
\hline 47 & Swedish Match da Amazônia S.A. & 12.039 \\
\hline 48 & Tec Toy S.A. & 27.865 \\
\hline 49 & Technos da Amazônia Ind. e Com. Ltda & 79.780 \\
\hline 50 & Thomson Multímidia Ltda & 72.003 \\
\hline 51 & Videolar S.A & 570.982 \\
\hline 52 & Visteon Amazonas Ltda & 98.739 \\
\hline \multicolumn{2}{|l|}{ Total } & 10.843 .648 \\
\hline
\end{tabular}

Fonte: Fipecafi. Melhores e Maiores. (1) Em US\$ de 31.12.2007. 


\section{APÊNDICE 3 - FATURAMENTO DAS EMPRESAS DA ZONA FRANCA DE MANAUS QUE PUBLICARAM AS DEMONSTRAÇÕES CONTÁBEIS - 2004}

\begin{tabular}{|c|c|c|}
\hline N. & Razão social & Faturamento Bruto \\
\hline 1 & Águas do Amazonas S.A. & 87.496 \\
\hline 2 & Arosuco Aromas e Sucos Ltda & 335.481 \\
\hline 3 & Bic Amazônia S/A & 220.547 \\
\hline 4 & Brastemp da Amazônia S.A. & 208.040 \\
\hline 5 & Caloi Norte S.A. & 120.247 \\
\hline 6 & CCE da Amazônia S.A. & 529.310 \\
\hline 7 & CGE - Ceará Geradora de Energia S.A. & 111.458 \\
\hline 8 & Cia. de Navegação da Amazônia & 27.780 \\
\hline 9 & Cisper da Amazônia S/A. & 35.938 \\
\hline 10 & Combras Comércio e Indústria do Brasil S/A & 209.440 \\
\hline 11 & Companhia Brasileira de Bicicletas & 117.618 \\
\hline 12 & Cookson Electronics Amazônia Ltda & 25.870 \\
\hline 13 & Copag da Amazônia & 24.631 \\
\hline 14 & Denso Industrial da Amazonia Ltda & 115.590 \\
\hline 15 & Dumont Saab do Brasil S.A. & 40.736 \\
\hline 16 & Emtec da Amazônia S.A. & 91.945 \\
\hline 17 & Evadin Indústrias Amazônia S.A. & 205.820 \\
\hline 18 & Fuji Photo Film da Amazônia Ltda. & 181.608 \\
\hline 19 & Gradiente Eletrônica S.A. & 729.790 \\
\hline 20 & Hermasa Navegação da Amazônia S/A. & 72.719 \\
\hline 21 & Injepet Embalagens da Amazônia S/A. & 144.381 \\
\hline 22 & Itautec Philco S.A. Grupo Itautec Philco & 933.140 \\
\hline 23 & Itautinga Agro-Industrial S.A. & 100.648 \\
\hline 24 & Lg Eletrocnics da Amazonia Ltda & 910.481 \\
\hline 25 & Magnum Indústria da Amazônia S.A. & 26.020 \\
\hline 26 & Manaus Energia S/A & 1.220 .937 \\
\hline 27 & Mineração Taboca S.A. & 92.605 \\
\hline 28 & Monark da Amazônia S.A. & 7.681 \\
\hline 29 & Multibrás da Amazônia S.A. & 113.313 \\
\hline 30 & Musashi da Amazônia Ltda & 70.099 \\
\hline 31 & Panasonic da Amazônia S.A. & 557.217 \\
\hline 32 & Pastore da Amazônia S.A. & 67.643 \\
\hline 33 & Petróleo Sabbá S.A. & 803.502 \\
\hline 34 & Procomp Amazônia Indústria Eletrônica Ltda. & 195.496 \\
\hline 35 & Prodam Processamento de Dados Amazonas SA & 19.766 \\
\hline 36 & Quartz Eletron Indústria e Comércio S/A. & 17.235 \\
\hline 37 & Rigesa da Amazônia S.A. & 38.530 \\
\hline 38 & Samsung Eletrônica da Amazônia Ltda & 1.332 .380 \\
\hline 39 & Samsung SDI Brasil Ltda & 678.630 \\
\hline 40 & Sanyo da Amazônia S.A. & 66.298 \\
\hline 41 & Seculus da Amazônia S.A. Jóias Relógios & 34.162 \\
\hline 42 & Semp Toshiba Amazonas S.A. & 854.473 \\
\hline 43 & Showa do Brasil Ltda & 157.547 \\
\hline 44 & Siemens Eletroeletrônica S.A. & 1.186 .700 \\
\hline 45 & Sonopress Rimo AM Ind. Com. Fonog. LTDA & 76.116 \\
\hline 46 & Swedish Match da Amazônia S.A. & 14.804 \\
\hline 47 & Tec Toy S.A. & 33.791 \\
\hline 48 & Technos da Amazônia Ind. e Com. Ltda & 85.524 \\
\hline 49 & Thomson Multímidia Ltda & 110.232 \\
\hline 50 & Videolar S.A & 768.830 \\
\hline 51 & Visteon Amazonas Ltda & 106.783 \\
\hline \multicolumn{2}{|l|}{ Total } & 14.317 .028 \\
\hline
\end{tabular}

Fonte: Fipecafi. Melhores e Maiores. (1) Em US\$ de 31.12.2007. 


\section{APÊNDICE 3 - FATURAMENTO DAS EMPRESAS DA ZONA FRANCA DE} MANAUS QUE PUBLICARAM AS DEMONSTRAÇÕES CONTÁBEIS - 2005

\begin{tabular}{|c|c|c|}
\hline N. & Razão social & Faturamento Bruto \\
\hline 1 & Compaz Componentes da Amazônia S/A & 89.178 \\
\hline 2 & Sanyo da Amazônia S.A. & 59.593 \\
\hline 3 & Evadin Indústrias Amazônia S.A. & 233.502 \\
\hline 4 & Petróleo Sabbá S.A. & 883.092 \\
\hline 5 & Combras Comércio e Indústria do Brasil S/A & 152.690 \\
\hline 6 & Gradiente Eletrônica S.A. & 927.875 \\
\hline 7 & Semp Toshiba Amazonas S.A. & 883.567 \\
\hline 8 & CCE da Amazônia S.A. & 582.314 \\
\hline 9 & Tec Toy S.A. & 36.803 \\
\hline 10 & Procomp Amazônia Indústria Eletrônica Ltda. & 262.285 \\
\hline 11 & Mineração Taboca S.A. & 66.374 \\
\hline 12 & Flextronics Manaus Ltda & 122.564 \\
\hline 13 & Panasonic da Amazônia S.A. & 585.079 \\
\hline 14 & Emtec da Amazônia S.A. & 84.221 \\
\hline 15 & Dumont Saab do Brasil S.A. & 39.266 \\
\hline 16 & Bic Amazônia S/A & 245.327 \\
\hline 17 & Sony Brasil Ltda & 683.927 \\
\hline 18 & Rigesa da Amazônia S.A. & 41.518 \\
\hline 19 & Caloi Norte S.A. & 106.730 \\
\hline 20 & Videolar S.A & 823.900 \\
\hline 21 & LG Eletronics da Amazonia Ltda & 1.079 .058 \\
\hline 22 & Trópico Sistemas e Telecomunicações da Amazônia Ltda & 33.935 \\
\hline 23 & Prodam Processamento de Dados Amazonas SA & 22.752 \\
\hline 24 & Manaus Energia S/A & 630.833 \\
\hline 25 & Arosuco Aromas e Sucos Ltda & 384.144 \\
\hline 26 & Visteon Amazonas Ltda & 104.230 \\
\hline 27 & Seculus da Amazônia S.A. Jóias Relógios & 40.563 \\
\hline 28 & Magnum Indústria da Amazônia S.A. & 28.691 \\
\hline 29 & Copag da Amazônia & 26.861 \\
\hline 30 & Brastemp da Amazônia S.A. & 236.107 \\
\hline 31 & Brasil \& Movimento S.A. & 181.845 \\
\hline 32 & Sonopress Rimo AM Ind. Com. Fonog. LTDA & 132.845 \\
\hline 33 & Siemens Eletroeletrônica S.A. & 1.507 .223 \\
\hline 34 & Cia. de Navegação da Amazônia & 32.788 \\
\hline 35 & Pastore da Amazônia S.A. & 73.934 \\
\hline 36 & Swedish Match da Amazônia S.A. & 14.093 \\
\hline 37 & Hermasa Navegação da Amazônia S/A. & 62.751 \\
\hline 38 & Cisper da Amazônia S/A. & 24.702 \\
\hline 39 & Fuji Photo Film da Amazônia Ltda. & 161.870 \\
\hline 40 & Águas do Amazonas S.A. & 89.894 \\
\hline 41 & Thomson Multímidia Ltda & 113.357 \\
\hline 42 & Showa do Brasil Ltda & 180.372 \\
\hline 43 & PST Indústria Eletrônica da Amazonia Ltda & 118.463 \\
\hline 44 & Samsung SDI Brasil Ltda & 634.111 \\
\hline 45 & Technos da Amazônia Ind. e Com. Ltda & 84.736 \\
\hline 46 & Cookson Electronics Amazônia Ltda & 24.810 \\
\hline 47 & CGE - Ceará Geradora de Energia S.A. & 119.402 \\
\hline 48 & Denso Industrial da Amazonia Ltda & 131.112 \\
\hline 49 & Tellerina Comércio de Presentes e Artigos p/ Decoração S.A. & 141.946 \\
\hline 50 & Unimed de Manaus Cooperativa de Trabalho Médico Ltda & 132.488 \\
\hline 51 & Pioneer do Brasil Ltda & 99.273 \\
\hline 52 & Cervejaria Miranda Corrêa S/A & 103.860 \\
\hline 53 & Orsa Embalagens da Amazônia S/A & 35.141 \\
\hline \multicolumn{2}{|l|}{ Total } & 13.697 .995 \\
\hline
\end{tabular}

Fonte: Fipecafi. Melhores e Maiores. (1) Em US\$ de 31.12.2007. 


\section{APÊNDICE 3 - FATURAMENTO DAS EMPRESAS DA ZONA FRANCA DE MANAUS QUE PUBLICARAM AS DEMONSTRAÇÕES CONTÁBEIS - 2006}

\begin{tabular}{|c|c|c|}
\hline N. & Razão social & Faturamento Bruto \\
\hline 1 & Compaz Componentes da Amazônia S/A & 104.900 \\
\hline 2 & Sanyo da Amazônia S.A. & 24.083 \\
\hline 3 & Petróleo Sabbá S.A. & 981.908 \\
\hline 4 & Gradiente Eletrônica S.A. & 1.130 .798 \\
\hline 5 & Semp Toshiba Amazonas S.A. & 992.964 \\
\hline 6 & Cemaz Industria Eletronica da Amazonia S/A & 648.623 \\
\hline 7 & Tec Toy S.A. & 28.048 \\
\hline 8 & Procomp Amazônia Indústria Eletrônica Ltda. & 202.073 \\
\hline 9 & Mineração Taboca S.A. & 146.340 \\
\hline 10 & Masa da Amazônia Ltda & 121.167 \\
\hline 11 & Emtec da Amazônia S.A. & 24.864 \\
\hline 12 & Dumont Saab do Brasil S.A. & 38.114 \\
\hline 13 & Bic Amazônia S/A & 254.686 \\
\hline 14 & Rigesa da Amazônia S.A. & 43.122 \\
\hline 15 & Caloi Norte S.A. & 92.341 \\
\hline 16 & Videolar S.A & 864.841 \\
\hline 17 & LG Eletrocnics da Amazonia Ltda & 1.160 .130 \\
\hline 18 & Prodam Processamento de Dados Amazonas SA & 30.180 \\
\hline 19 & Manaus Energia S/A & 790.543 \\
\hline 20 & Arosuco Aromas e Sucos Ltda & 395.269 \\
\hline 21 & Seculus da Amazônia S.A. Jóias Relógios & 43.164 \\
\hline 22 & Magnum Indústria da Amazônia S.A. & 27.504 \\
\hline 23 & Copag da Amazônia & 29.191 \\
\hline 24 & Brastemp da Amazônia S.A. & 218.682 \\
\hline 25 & Brasil \& Movimento S.A. & 250.194 \\
\hline 26 & Sonopress Rimo AM Ind. Com. Fonog. LTDA & 196.238 \\
\hline 27 & Siemens Eletroeletrônica S.A. & 431.434 \\
\hline 28 & Cia. de Navegação da Amazônia & 28.542 \\
\hline 29 & Pastore da Amazônia S.A. & 71.256 \\
\hline 30 & Swedish Match da Amazônia S.A. & 12.914 \\
\hline 31 & Hermasa Navegação da Amazônia S/A. & 72.535 \\
\hline 32 & Cisper da Amazônia S/A. & 17.506 \\
\hline 33 & Águas do Amazonas S.A. & 92.150 \\
\hline 34 & Thomson Multímidia Ltda & 166.612 \\
\hline 35 & Showa do Brasil Ltda & 207.099 \\
\hline 36 & PST Indústria Eletrônica da Amazonia Ltda & 145.619 \\
\hline 37 & Samsung SDI Brasil Ltda & 487.087 \\
\hline 38 & Confederação Brasileira de Atletismo & 8.394 \\
\hline 39 & Technos da Amazônia Ind. e Com. Ltda & 88.564 \\
\hline 40 & Cookson Electronics Amazônia Ltda & 29.875 \\
\hline 41 & CGE - Ceará Geradora de Energia S.A. & 107.222 \\
\hline 42 & Breitener Energética S.A & 24.072 \\
\hline 43 & Tellerina Com. de Presentes e Art. p/ Decoração S.A. & 180.146 \\
\hline 44 & Pioneer do Brasil Ltda & 128.243 \\
\hline 45 & Indústria de Café Manaus Ltda & 12.873 \\
\hline 46 & Cervejaria Miranda Corrêa S/A & 256.038 \\
\hline 47 & Orsa Embalagens da Amazônia S/A & 36.039 \\
\hline 48 & Digibras Indústria do Brasil S/A & 147.922 \\
\hline 49 & Placibras da Amazônia Ltda & 176.713 \\
\hline \multicolumn{2}{|l|}{ Total } & 11.768 .822 \\
\hline
\end{tabular}

Fonte: Fipecafi. Melhores e Maiores. (1) Em US\$ de 31.12.2007. 


\section{APÊNDICE 3 - FATURAMENTO DAS EMPRESAS DA ZONA FRANCA DE MANAUS QUE PUBLICARAM AS DEMONSTRAÇÕES CONTÁBEIS - 2007}

\begin{tabular}{|c|c|c|}
\hline $\mathbf{N}$. & Razão social & Faturamento Bruto \\
\hline 1 & Compaz Componentes da Amazônia S/A & 103.136 \\
\hline 2 & Petróleo Sabbá S.A. & 985.901 \\
\hline 3 & Semp Toshiba Amazonas S.A. & 786.568 \\
\hline 4 & Cemaz Industria Eletronica da Amazonia S/A & 525.626 \\
\hline 5 & Procomp Amazônia Indústria Eletrônica Ltda. & 221.773 \\
\hline 6 & Procter \& Gamble do Brasil S.A. & 1.122 .029 \\
\hline 7 & Mineração Taboca S.A. & 130.356 \\
\hline 8 & Masa da Amazônia Ltda & 88.502 \\
\hline 9 & Dumont Saab do Brasil S.A. & 45.568 \\
\hline 10 & Bic Amazônia S/A & 224.529 \\
\hline 11 & Rigesa da Amazônia S.A. & 38.863 \\
\hline 12 & Caloi Norte S.A. & 98.309 \\
\hline 13 & Crown Embalagens Metálicas da Amazônia S.A. & 335.963 \\
\hline 14 & Videolar S.A & 715.431 \\
\hline 15 & LG Eletrocnics da Amazonia Ltda & 1.377 .139 \\
\hline 16 & Samsung Eletrônica da Amazônia Ltda & 2.373.614 \\
\hline 17 & Manaus Energia S/A & 683.968 \\
\hline 18 & Seculus da Amazônia Indústria e Comércio S.A. & 69.628 \\
\hline 19 & Brastemp da Amazônia S.A. & 266.844 \\
\hline 20 & Brasil \& Movimento S.A. & 312.167 \\
\hline 21 & Hermasa Navegação da Amazônia S/A. & 72.977 \\
\hline 22 & Engepack Embalagens da Amazônia Ltda. & 125.633 \\
\hline 23 & Águas do Amazonas S.A. & 109.630 \\
\hline 24 & Thomson Multímidia Ltda & 223.078 \\
\hline 25 & PST Eletrônica S/A & 175.853 \\
\hline 26 & Technos da Amazônia Ind. e Com. Ltda & 91.489 \\
\hline 27 & Cookson Electronics Amazônia Ltda & 36.390 \\
\hline 28 & Mercantil Nova Era Ltda & 165.852 \\
\hline 29 & Tellerina Comércio de Presentes e Artigos p/ Decoração S.A. & 263.174 \\
\hline 30 & Pioneer do Brasil Ltda & 149.894 \\
\hline 31 & Digibras Indústria do Brasil S/A & 375.306 \\
\hline 32 & Placibras da Amazônia Ltda & 208.622 \\
\hline \multicolumn{2}{|l|}{ Total } & 12.503.812 \\
\hline
\end{tabular}

Fonte: Fipecafi. Melhores e Maiores. (1) Em US\$ de 31.12.2007. 



\section{APÊNDICE 4 - PRODUTO INTERNO BRUTO A PREÇOS CORRENTES E PRODUTO INTERNO BRUTO PER CAPITA SEGUNDO AS GRANDES REGIÕES E UNIDADES DA FEDERAÇÃO - 2003 A 2006}

\begin{tabular}{|c|c|c|c|c|c|c|c|c|}
\hline \multirow{3}{*}{$\begin{array}{l}\text { Grandes Regiões e } \\
\text { Unidades da Federação }\end{array}$} & \multicolumn{8}{|c|}{ Produto Interno Bruto } \\
\hline & \multicolumn{2}{|l|}{2003} & \multicolumn{2}{|l|}{2004} & \multicolumn{2}{|l|}{2005} & \multicolumn{2}{|l|}{2006} \\
\hline & $\begin{array}{c}\text { A preços } \\
\text { correntes } \\
(1000 \mathrm{R} \$)\end{array}$ & $\begin{array}{c}P e r \\
\text { capita } \\
\text { (R\$) }\end{array}$ & $\begin{array}{c}\text { A preços } \\
\text { correntes } \\
(1000 \mathrm{R} \$)\end{array}$ & $\begin{array}{c}P e r \\
\text { capita } \\
(\mathrm{R} \$)\end{array}$ & $\begin{array}{c}\text { A preços } \\
\text { correntes } \\
(1000 \mathrm{R} \$)\end{array}$ & $\begin{array}{c}P e r \\
\text { capita } \\
(\mathrm{R} \$)\end{array}$ & $\begin{array}{c}\text { A preços } \\
\text { correntes } \\
(1000 \mathrm{R} \$)\end{array}$ & $\begin{array}{c}\text { Per } \\
\text { capita } \\
(\mathrm{R} \$)\end{array}$ \\
\hline Norte & 81199581 & 5780 & 96012341 & 6680 & 106441710 & 7241 & 120013924 & 7989 \\
\hline Rondônia & 9750818 & 6594 & 11260424 & 7209 & 12884047 & 8396 & 13110092 & 8391 \\
\hline Acre & 3304771 & 5278 & 3940315 & 6251 & 4482920 & 6694 & 4834771 & 7041 \\
\hline Amazonas & 24977170 & 8100 & 30313735 & 9658 & 33352137 & 10318 & 39166314 & 11829 \\
\hline Roraima & 2737003 & 7455 & 2811079 & 7361 & 3179287 & 8125 & 3660153 & 9075 \\
\hline Pará & 29754565 & 4448 & 35562846 & 5192 & 39121138 & 5612 & 44375766 & 6241 \\
\hline Amapá & 3434107 & 6220 & 3846126 & 7026 & 4361255 & 7335 & 5260099 & 8543 \\
\hline Tocantins & 7241147 & 5784 & 8277816 & 6556 & 9060926 & 6939 & 9606730 & 7210 \\
\hline Nordeste & 217037426 & 4355 & 247042512 & 4899 & 280545055 & 5499 & 311174975 & 6029 \\
\hline Maranhão & 18483300 & 3112 & 21604577 & 3588 & 25334591 & 4151 & 28621445 & 4628 \\
\hline Piauí & 8777044 & 2978 & 9816735 & 3297 & 11129201 & 3701 & 12790396 & 4213 \\
\hline Ceará & 32565454 & 4145 & 36866273 & 4622 & 40935248 & 5055 & 46309884 & 5636 \\
\hline Rio Grande do Norte & 13515095 & 4626 & 15580455 & 5260 & 17869516 & 5950 & 20556655 & 6754 \\
\hline Paraíba & 14157834 & 3998 & 15022399 & 4210 & 16868638 & 4691 & 19953459 & 5507 \\
\hline Pernambuco & 39308429 & 4774 & 44010905 & 5287 & 49921744 & 5933 & 55504917 & 6528 \\
\hline Alagoas & 11209511 & 3805 & 12890511 & 4324 & 14139346 & 4688 & 15753395 & 5164 \\
\hline Sergipe & 10873835 & 5718 & 12167429 & 6289 & 13427437 & 6824 & 15125895 & 7560 \\
\hline Bahia & 68146924 & 5031 & 79083228 & 5780 & 90919335 & 6581 & 96558929 & 6922 \\
\hline Sudeste & 947748381 & 12424 & 1083974746 & 14009 & 1213863408 & 15469 & 1345509830 & 16912 \\
\hline Minas Gerais & 148822788 & 7937 & 177324816 & 9336 & 192639256 & 10014 & 214813511 & 11028 \\
\hline Espírito Santo & 31063717 & 9425 & 40217397 & 11998 & 47222579 & 13855 & 52781902 & 15236 \\
\hline Rio de Janeiro & 188014960 & 12514 & 222945041 & 14664 & 247017528 & 16057 & 275362726 & 17695 \\
\hline São Paulo & 579846916 & 14788 & 643487492 & 16158 & 726984045 & 17976 & 802551691 & 19548 \\
\hline Sul & 300858677 & 11440 & 337657404 & 12677 & 356211309 & 13206 & 386736960 & 14162 \\
\hline Paraná & 109458876 & 10935 & 122433731 & 12080 & 126676836 & 12344 & 136680839 & 13158 \\
\hline Santa Catarina & 66848534 & 11764 & 77392991 & 13403 & 85316275 & 14543 & 93173498 & 15638 \\
\hline Rio Grande do Sul & 124551267 & 11742 & 137830682 & 12850 & 144218198 & 13298 & 156882623 & 14310 \\
\hline Centro-Oeste & 153103630 & 12228 & 176811355 & 13846 & 190177811 & 14606 & 206360858 & 15552 \\
\hline Mato Grosso do Sul & 19273681 & 8772 & 21105170 & 9461 & 21650854 & 9561 & 24355395 & 10599 \\
\hline Mato Grosso & 27888658 & 10347 & 36961123 & 13445 & 37465937 & 13365 & 35284471 & 12350 \\
\hline Goiás & 42836390 & 7937 & 48020949 & 8718 & 50534408 & 8992 & 57090883 & 9962 \\
\hline Distrito Federal & 63104900 & 28282 & 70724113 & 30992 & 80526612 & 34515 & 89630109 & 37600 \\
\hline Total & 1699947694 & & 1941498358 & & 2147239292 & & 2369796546 & \\
\hline
\end{tabular}

Fonte: IBGE. Disponível em: <http: www.ibge.gov.br>. Acesso em: 15/12/2008 



\section{APÊNDICE 5 - PRODUTO INTERNO BRUTO A PREÇOS CORRENTES E PRODUTO INTERNO BRUTO PER CAPITA DAS PRINCIPAIS CIDADES BRASILEIRAS - 2003 A 2006}

\begin{tabular}{|c|c|c|c|c|c|c|c|c|}
\hline \multirow{3}{*}{$\begin{array}{l}\text { Cidades e } \\
\text { Regiões }\end{array}$} & \multicolumn{8}{|c|}{ Produto Interno Bruto } \\
\hline & \multicolumn{2}{|c|}{2003} & \multicolumn{2}{|l|}{2004} & \multicolumn{2}{|c|}{2005} & \multicolumn{2}{|c|}{2006} \\
\hline & 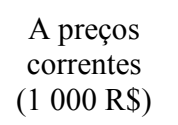 & $\begin{array}{c}\mathrm{Per} \\
\text { capita } \\
(\mathrm{R} \$)\end{array}$ & $\begin{array}{l}\text { A preços } \\
\text { correntes } \\
(1000 \mathrm{R} \$)\end{array}$ & $\begin{array}{c}\text { Per } \\
\text { capita } \\
(\mathrm{R} \$)\end{array}$ & $\begin{array}{l}\text { A preços } \\
\text { correntes } \\
(1000 \mathrm{R} \$)\end{array}$ & $\begin{array}{c}P e r \\
\text { capita } \\
(\mathrm{R} \$)\end{array}$ & $\begin{array}{l}\text { A preços } \\
\text { correntes } \\
(1000 \mathrm{R} \$)\end{array}$ & $\begin{array}{c}\text { Per } \\
\text { capita } \\
(\mathrm{R} \$)\end{array}$ \\
\hline \multicolumn{9}{|l|}{ Norte } \\
\hline Manaus & 20640758 & 13260 & 25475127 & 15996 & 27594771 & 16778 & 31916257 & 18902 \\
\hline Belém & 8838679 & 6496 & 10348720 & 7464 & 11277478 & 8022 & 12520322 & 8765 \\
\hline \multicolumn{9}{|l|}{ Nordeste } \\
\hline Fortaleza & 15303784 & 6681 & 17217737 & 7381 & 19675992 & 8285 & 22537716 & 9325 \\
\hline Recife & 13098429 & 8894 & 14414268 & 9694 & 16322816 & 10875 & 18318451 & 12091 \\
\hline Salvador & 16770662 & 6480 & 19826156 & 7533 & 22527374 & 8426 & 24072400 & 8870 \\
\hline \multicolumn{9}{|l|}{ Sudeste } \\
\hline Belo Horizonte & 23197223 & 9973 & 27189964 & 11567 & 28786329 & 12119 & 32725361 & 13636 \\
\hline São Paulo & 209555133 & 19494 & 225170382 & 20775 & 261455917 & 23925 & 282852338 & 25675 \\
\hline Rio de Janeiro & 95751484 & 15935 & 112674641 & 18620 & 117771722 & 19325 & 127956075 & 20851 \\
\hline \multicolumn{9}{|l|}{ Sul } \\
\hline Curitiba & 23828224 & 14047 & 26755257 & 15492 & 29672801 & 16880 & 32153307 & 17977 \\
\hline Porto Alegre & 21871109 & 15577 & 23780238 & 16790 & 28132955 & 19691 & 30116002 & 20900 \\
\hline \multicolumn{9}{|l|}{ Centro-Oeste } \\
\hline Goiânia & 10757548 & 9258 & 12368277 & 10469 & 13520904 & 11258 & 15872191 & 13006 \\
\hline Brasília & 63104900 & 28282 & 70724113 & 30992 & 80526612 & 34515 & 89630109 & 37600 \\
\hline
\end{tabular}

Fonte: IBGE. Disponível em: <http: www.ibge.gov.br>. Acesso em: 15/12/2008 



\section{APÊNDICE 6 - EMPRESAS QUE APRESENTARAM A DEMONSTRAÇÃO DE VALOR ADICIONADO (DVA) NO ANO DE 2003 A 2007}

\begin{tabular}{|c|c|c|c|c|c|c|}
\hline \multirow{2}{*}{\multicolumn{2}{|c|}{ Empresas }} & \multicolumn{5}{|c|}{ Anos } \\
\hline & & \multirow{2}{*}{$\begin{array}{c}\mathbf{2 0 0 3} \\
\text { SIM }\end{array}$} & \multirow{2}{*}{$\begin{array}{c}2004 \\
\text { SIM }\end{array}$} & \multirow{2}{*}{$\begin{array}{l}2005 \\
\text { SIM }\end{array}$} & \multirow{2}{*}{$\begin{array}{c}2006 \\
\text { SIM }\end{array}$} & \multirow{2}{*}{$\begin{array}{r}2007 \\
\text { NÃO }\end{array}$} \\
\hline 1 & Arosuco Aromas e Sucos Ltda & & & & & \\
\hline 2 & Brasil \& Movimento S.A. (2) & SIM & SIM & NÃO & SIM & SIM \\
\hline 3 & Brastemp da Amazônia S.A. & SIM & SIM & SIM & SIM & SIM \\
\hline 4 & Caloi Norte S.A. & SIM & SIM & SIM & SIM & NÃO \\
\hline 5 & CCE da Amazônia S.A. & SIM & SIM & SIM & NÃO & NÃO \\
\hline 6 & Cemaz Indústria Eletrônica da Amazônia S.A. & NÃO & NÃO & NÃO & NÃO & SIM \\
\hline 7 & Combras Comércio e Indústria do Brasil S/A & NÃO & SIM & SIM & NÃO & NÃO \\
\hline 8 & Compaz Componentes da Amazônia S.A. & SIM & NÃO & SIM & NÃO & SIM \\
\hline 9 & Digibrás Indústria do Brasil S.A. & NÃO & NÃO & NÃO & NÃO & SIM \\
\hline 10 & Emtec da Amazônia S.A. & SIM & SIM & NÃO & NÃO & NÃO \\
\hline 11 & Engepack Embalagens da Amazônia Ltda & NÃO & NÃO & NÃO & NÃO & SIM \\
\hline 12 & Gradiente Eletrônica S.A. & NÃO & SIM & SIM & SIM & NÃO \\
\hline 13 & Lg Eletrocnics da Amazônia Ltda & SIM & SIM & SIM & NÃO & NÃO \\
\hline 14 & Multibrás da Amazônia S.A. (1) & SIM & SIM & SIM & SIM & NÃO \\
\hline 15 & Panasonic da Amazônia S.A. & SIM & SIM & NÃO & NÃO & NÃO \\
\hline 16 & Pastore da Amazônia S.A. & SIM & NÃO & NÃO & SIM & NÃO \\
\hline 17 & Placibrás da Amazônia Ltda & NÃO & NÃO & NÃO & NÃO & SIM \\
\hline 18 & Procomp Amazônia Indústria Eletrônica Ltda. & SIM & SIM & SIM & SIM & SIM \\
\hline 19 & Rigesa da Amazônia S.A. & SIM & SIM & SIM & SIM & SIM \\
\hline 20 & Séculus da Amazônia S.A. Jóias e Relógios & NÃO & NÃO & NÃO & SIM & SIM \\
\hline 21 & Semp Toshiba Amazonas S.A. & SIM & SIM & SIM & SIM & SIM \\
\hline 22 & Tec Toy S.A. & SIM & SIM & SIM & SIM & NÃO \\
\hline 23 & Technos da Amazônia Ind. E Com. Ltda & NÃO & SIM & SIM & SIM & NÃO \\
\hline 24 & Thomson Multímidia Ltda & SIM & NÃO & NÃO & NÃO & SIM \\
\hline 25 & Trópico Sistemas e Telec. da Amazônia Ltda & NÃO & NÃO & SIM & NÃO & NÃO \\
\hline 26 & Videolar S.A & SIM & SIM & SIM & SIM & SIM \\
\hline
\end{tabular}

(1) Em 2005, a denominação social era Flextronics Manaus Ltda.

(2) Até 2005, a denominação social era Companhia Brasileira de Bicicletas

Fonte: Fipecafi. Melhores e Maiores. 

Relação das Empresas Pares - 2003

\begin{tabular}{|c|c|c|c|c|}
\hline \multicolumn{2}{|c|}{ Instaladas na Zona Franca de Manaus } & \multirow[b]{2}{*}{ Setor } & \multicolumn{2}{|c|}{ Instaladas Fora da Zona Franca de Manaus } \\
\hline Empresas & $\begin{array}{c}\text { Faturamento } \\
\text { (US\$ mil, de } \\
31.12 .2007 \text { ) }\end{array}$ & & \begin{tabular}{|c|} 
Faturamento \\
(US\$ mil, de \\
$31.12 .2007)$ \\
\end{tabular} & Empresas \\
\hline Caloi Norte S.A. & 105.801 & Auto-indústria & 116.043 & Master Sistemas Automotivos Ltda. \\
\hline Companhia Brasileira de Bicicletas & 100.725 & Auto-indústria & 94.650 & Acumuladores Moura S.A. \\
\hline Videolar S.A & 562.283 & Diversos (1) & 370.579 & CPM S.A. \\
\hline Emtec da Amazônia S.A. & 42.973 & Diversos (1) & 37.500 & Unitech Tecnologia de Informacão Ltda. \\
\hline Lg Eletrocnics da Amazonia Ltda & 692.453 & Eletroeletrônico & 634.186 & Ericsson Telecomunicações S.A. \\
\hline Semp Toshiba Amazonas S.A. & 653.203 & Eletroeletrônico & 596.025 & Alcatel Telecomunicações S.A. \\
\hline Panasonic da Amazônia S.A. & 510.775 & Eletroeletrônico & 294.620 & Pirelli Energia Cabos e Sistemas do Brasil S.A. \\
\hline CCE da Amazônia S.A. & 479.546 & Eletroeletrônico & 354.388 & Arno S.A. \\
\hline Brastemp da Amazônia S.A. & 254.327 & Eletroeletrônico & 277.427 & Ficap S.A. \\
\hline Compaz Componentes da Amazônia S/A & 101.811 & Eletroeletrônico & 101.941 & Furukawa Industrial S.A. Produtos Elétricos \\
\hline Tec Toy S.A. & 28.046 & Eletroeletrônico & 30.726 & Digitel S.A. - Indústria Eletrônica \\
\hline Procomp Amazônia Indústria Eletrônica Ltda. & 186.009 & Indústria Digital & 176.157 & Tecnologia Bancária S.A. \\
\hline Thomson Multímidia Ltda & 71.449 & Indústria Digital & 71.617 & Gedas do Brasil Ltda. \\
\hline Rigesa da Amazônia S.A. & 32.344 & Papel e Celulose & 114.847 & Primo Tedesco S.A. \\
\hline Multibrás da Amazônia S.A. & 92.214 & Quím.Petroquímica & 113.435 & White Martins Gases Industriais do Norte S.A. \\
\hline Pastore da Amazônia S.A. & 38.898 & Quím.Petroquímica & 53.408 & Fábrica de Artefatos de Latex São Roque S.A. \\
\hline Total & 3.952 .857 & & 3.437 .549 & \\
\hline
\end{tabular}


Relação das Empresas Pares - 2004

\begin{tabular}{|c|c|c|c|c|}
\hline \multicolumn{2}{|c|}{ Instaladas na Zona Franca de Manaus } & \multirow[b]{2}{*}{ Setor } & \multicolumn{2}{|c|}{ Instaladas Fora da Zona Franca de Manaus } \\
\hline Empresas & $\begin{array}{c}\text { Faturamento } \\
\text { (US\$ mil, de } \\
\text { 31.12.2007) }\end{array}$ & & $\begin{array}{c}\text { Faturamento } \\
\text { (US\$ mil, de } \\
31.12 .2007 \text { ) }\end{array}$ & Empresas \\
\hline Caloi Norte S.A. & 121.866 & Auto-indústria & 168.110 & Master Sistemas Automotivos Ltda. \\
\hline Companhia Brasileira de Bicicletas & 119.668 & Auto-indústria & 127.862 & Acumuladores Moura S.A. \\
\hline Videolar S.A & 739.604 & Diversos (1) & 290.945 & CPM S.A. \\
\hline Emtec da Amazônia S.A. & 93.089 & Diversos (1) & 46.904 & Unitech Tecnologia de Informação Ltda. \\
\hline Technos da Amazônia Ind. e Com. Ltda & 85.524 & Diversos (1) & 97.880 & Proceda Tecnologia e Informática S.A. \\
\hline$\underline{\text { Lg Eletrocnics da Amazonia Ltda }}$ & 899.895 & Eletroeletrônico & 1.228 .330 & Ericsson Telecomunicações S.A. \\
\hline Semp Toshiba Amazonas S.A. & 856.386 & Eletroeletrônico & 751.826 & Alcatel Telecomunicações S.A. \\
\hline Gradiente Eletrônica S.A. & 738.516 & Eletroeletrônico & 229.090 & Black \&Decker do Brasil Ltda. \\
\hline Panasonic da Amazônia S.A. & 555.038 & Eletroeletrônico & 366.564 & Pirelli Energia Cabos e Sistemas do Brasil S.A. \\
\hline CCE da Amazônia S.A. & 534.912 & Eletroeletrônico & 383.132 & Arno S.A. \\
\hline Combras Comércio e Indústria do Brasil S/A & 258.859 & Eletroeletrônico & 189.622 & Lorenzetti S.A. Ind. Bras. Eletrometalúrgicas \\
\hline Brastemp da Amazônia S.A. & 210.836 & Eletroeletrônico & 161.392 & Stemac S.A. Grupos Geradores \\
\hline Tec Toy S.A. & 34.464 & Eletroeletrônico & 43.431 & Digitel S.A. - Indústria Eletrônica \\
\hline Procomp Amazônia Indústria Eletrônica Ltda. & 198.855 & Indústria Digital & 150.070 & Tecnologia Bancária S.A. \\
\hline Rigesa da Amazônia S.A. & 38.857 & Papel e Celulose & 113.222 & Primo Tedesco S.A. \\
\hline Multibrás da Amazônia S.A. & 114.398 & Quím. e Petroquímica & 109.309 & Eka Chemicals do Brasil S/A \\
\hline Total & 5.600 .767 & & 4.457.689 & \\
\hline
\end{tabular}

(1) Considerada Indústria digital 
Relação das Empresas Pares - 2005

\begin{tabular}{|c|c|c|c|c|}
\hline \multicolumn{2}{|c|}{ Instaladas na Zona Franca de Manaus } & \multirow[b]{2}{*}{ Setor } & \multicolumn{2}{|c|}{ Instaladas Fora da Zona Franca de Manaus } \\
\hline Empresas & $\begin{array}{c}\text { Faturamento } \\
\text { (US\$ mil, de } \\
\text { 31.12.2007) }\end{array}$ & & $\begin{array}{c}\text { Faturamento } \\
\text { (US\$ mil, de } \\
31.12 .2007 \text { ) }\end{array}$ & Empresas \\
\hline Caloi Norte S.A. & 106.730 & Auto-indústria & 127.078 & WHB Componentes Automotivos S.A. \\
\hline Videolar S.A & 771.956 & Diversos (1) & 404.475 & CPM S.A. \\
\hline Technos da Amazônia Ind. e Com. Ltda & 89.679 & Diversos (1) & 98.481 & Probank S.A. \\
\hline LG Eletronics da Amazonia Ltda & 1.061 .163 & Eletroeletrônico & 472.532 & Prysmian Energia Cabos e Sist.do Brasil S.A. \\
\hline Gradiente Eletrônica S.A. & 927.875 & Eletroeletrônico & 224.036 & Stemac S.A. Grupos Geradores \\
\hline Semp Toshiba Amazonas S.A. & 856.336 & Eletroeletrônico & 698.457 & Alcatel Telecomunicações S.A. \\
\hline CCE da Amazônia S.A. & 582.314 & Eletroeletrônico & 417.912 & Arno S.A. \\
\hline Brastemp da Amazônia S.A. & 236.107 & Eletroeletrônico & 224.106 & Lorenzetti S.A. Ind. Bras. Eletrometalúrgicas \\
\hline Combras Comércio e Indústria do Brasil S/A & 174.142 & Eletroeletrônico & 174.465 & Prysmian Telecomunicações \\
\hline Compaz Componentes da Amazônia S/A & 89.178 & Eletroeletrônico & 119.135 & Toledo do Brasil Indústria de Balanças Ltda. \\
\hline Tec Toy S.A. & 36.803 & Eletroeletrônico & 31.192 & Koblitz S.A \\
\hline Trópico Sistemas e Telec. da Amazônia Ltda & 33.935 & Eletroeletrônico & 57.002 & Intral S.A. Ind. de Materiais Elétricos \\
\hline Procomp Amazônia Indústria Eletrônica Ltda. & 262.272 & Indústria Digital & 166.742 & Tecnologia Bancária S.A. \\
\hline Rigesa da Amazônia S.A. & 41.547 & Papel e Celulose & 83.743 & Papirus Indústria de Papel SA. \\
\hline Flextronics Manaus Ltda & 122.564 & Quím. e Petroquímica & 122.402 & Industrial Levorin S.A. \\
\hline Total & 5.392 .601 & & 3.421 .758 & \\
\hline
\end{tabular}


Relação das Empresas Pares - 2006

\begin{tabular}{|c|c|c|c|c|}
\hline \multicolumn{2}{|c|}{ Instaladas na Zona Franca de Manaus } & \multirow[b]{2}{*}{ Setor } & \multicolumn{2}{|c|}{ Instaladas Fora da Zona Franca de Manaus } \\
\hline Empresas & $\begin{array}{c}\text { Faturamento } \\
\text { (USS mil, de } \\
31.12 .2007 \text { ) }\end{array}$ & & $\begin{array}{c}\text { Faturamento } \\
\text { (USS mil, de } \\
31.12 .2007 \text { ) }\end{array}$ & Empresas \\
\hline Brasil \& Movimento S.A. & 250.195 & Auto-indústria & 172.917 & Acumuladores Moura S.A. \\
\hline Caloi Norte S.A. & 92.341 & Auto-indústria & 138.295 & Resil Minas Indústria e Comércio Ltda. \\
\hline Videolar S.A & 772.449 & Diversos (1) & 416.612 & CPM S.A. \\
\hline Technos da Amazônia Ind. e Com. Ltda & 84.456 & Diversos (1) & 120.055 & Probank S.A. \\
\hline Seculus da Amazônia S.A. Jóias Relógios & 43.164 & Diversos (1) & 62.915 & Daruma Telecomunicações e Informática S.A. \\
\hline Gradiente Eletrônica S.A. & 1.130 .798 & Eletroeletrônico & 775.347 & Ericsson Telecomunicações S.A. \\
\hline Semp Toshiba Amazonas S.A. & 987.659 & Eletroeletrônico & 643.509 & Alcatel Telecomunicações S.A. \\
\hline Brastemp da Amazônia S.A. & 218.682 & Eletroeletrônico & 211.233 & Black \& Decker do Brasil Ltda. \\
\hline Tec Toy S.A. & 28.048 & Eletroeletrônico & 40.408 & Digitel S.A. - Indústria Eletrônica \\
\hline Procomp Amazônia Indústria Eletrônica Ltda. & 201.298 & Indústria Digital & 174.952 & Tecnologia Bancária S.A. \\
\hline Rigesa da Amazônia S.A. & 43.141 & Papel e Celulose & 44.445 & Conpel - Cia. Nordestina de Papel \\
\hline Masa da Amazônia Ltda & 121.167 & Quím. e Petroquímica & 115.842 & Industrial Levorin S.A. \\
\hline Pastore da Amazônia S.A. & 71.256 & Quím. e Petroquímica & 63.411 & Poly-Vac S.A. Ind. e Comércio de Embalagens \\
\hline Total & 4.044.654 & & 2.979.941 & \\
\hline
\end{tabular}

(1) Considerada Indústria digital 
Relação das Empresas Pares - 2007

\begin{tabular}{|c|c|c|c|c|}
\hline \multicolumn{2}{|c|}{ Instaladas na Zona Franca de Manaus } & \multirow[b]{2}{*}{ Setor } & \multicolumn{2}{|c|}{ Instaladas Fora da Zona Franca de Manaus } \\
\hline Empresas & $\begin{array}{c}\text { Faturamento } \\
\text { (USS mil, de } \\
31.12 .2007 \text { ) }\end{array}$ & & $\begin{array}{c}\text { Faturamento } \\
\text { (US\$ mil, de } \\
31.12 .2007)\end{array}$ & Empresas \\
\hline Brasil \& Movimento S.A. & 307.085 & Auto-indústria & 248.419 & Acumuladores Moura S.A. \\
\hline Videolar S.A & 651.083 & Diversos (1) & 464.597 & CPM S.A. \\
\hline Seculus da Amazônia Indústria e Comércio S.A. & 67.098 & Diversos (1) & 178.713 & Gennari \& Peartree Projetos e Sistemas Ltda. \\
\hline Semp Toshiba Amazonas S.A. & 776.667 & Eletroeletrônico & 712.716 & Alcatel- Lucent Brasil S.A \\
\hline Cemaz Industria Eletronica da Amazonia S/A & 525.626 & Eletroeletrônico & 400.285 & Schneider Electric Brasil Ltda \\
\hline Brastemp da Amazônia S.A. & 266.844 & Eletroeletrônico & 259.300 & Lorenzetti S.A. Ind. Bras. Eletrometalúrgicas \\
\hline Placibras da Amazônia Ltda & 208.622 & Eletroeletrônico & 194.420 & Wirex Cable S.A. \\
\hline Compaz Componentes da Amazônia S/A & 103.136 & Eletroeletrônico & 147.224 & Intelbras S.A. Ind. Telec.Eletrônica Brasileira \\
\hline Digibras Indústria do Brasil S/A & 375.306 & Indústria Digital & 304.738 & Politec Tecnologia da Informação S.A \\
\hline Thomson Multímidia Ltda & 223.078 & Indústria Digital & 229.553 & Totvs S.A \\
\hline Procomp Amazônia Indústria Eletrônica Ltda. & 221.753 & Indústria Digital & 159.126 & Tecnologia Bancária S.A. \\
\hline Rigesa da Amazônia S.A. & 38.863 & Papel e Celulose & 47.711 & Conpel - Cia. Nordestina de Papel \\
\hline Engepack Embalagens da Amazônia Ltda. & 129.914 & Quím. e Petroquímica & 104.878 & Dynea Brasil S.A. \\
\hline Total & 3.895 .075 & & 3.451 .680 & \\
\hline
\end{tabular}

(1) Considerada Indústria digital 

APÊNDICE 8 - DVA CONSOLIDADA DAS EMPRESAS DA ZONA FRANCA DE

MANAUS - 2003 A 2007

DEMONSTRAÇÃO DO VALOR ADICIONADO DO EXERCÍCIO DE 2003

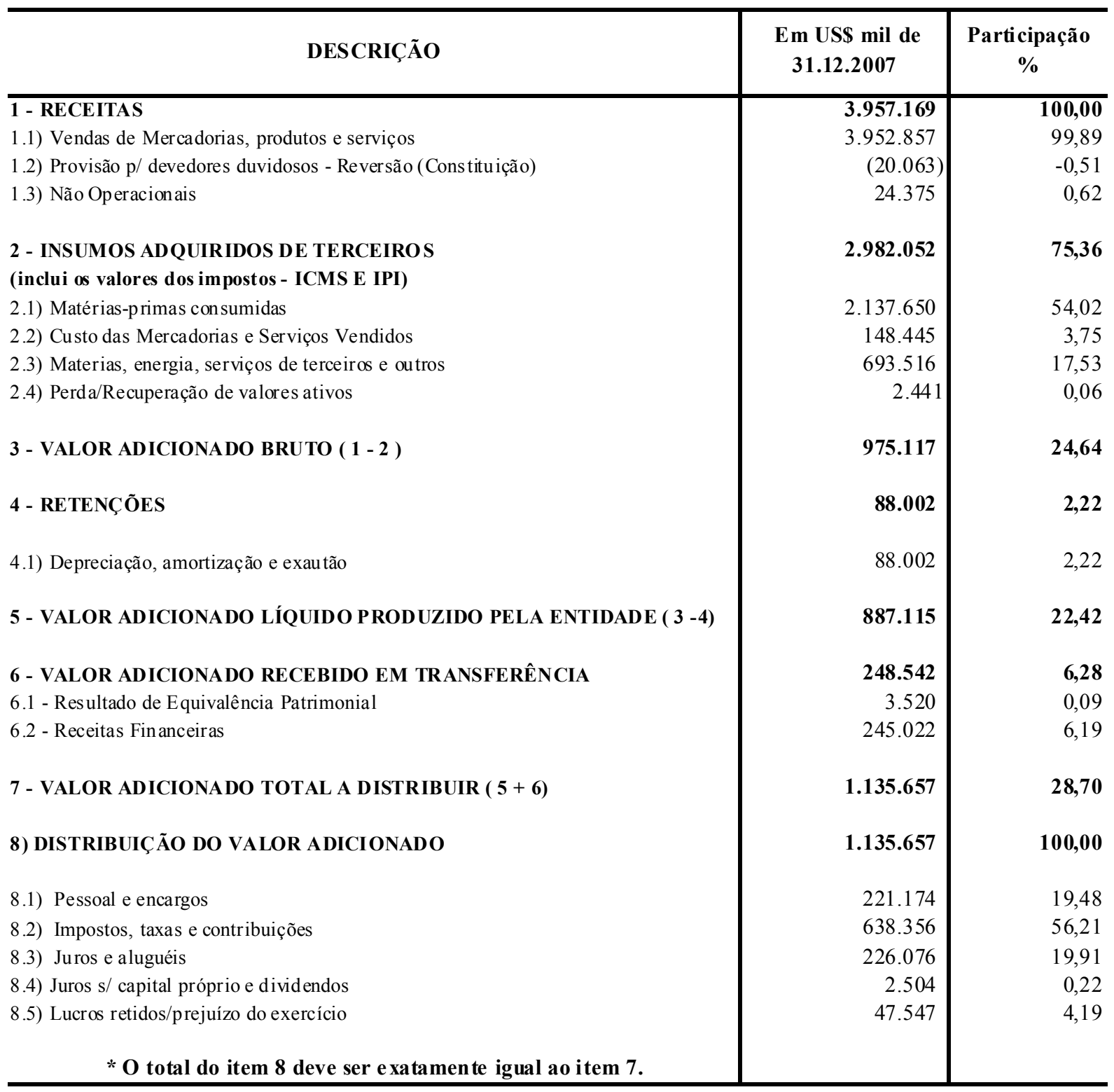


APÊNDICE 8 - DVA CONSOLIDADA DAS EMPRESAS DA ZONA FRANCA DE MANAUS - 2003 A 2007

DEMONSTRAÇÃO DO VALOR ADICIONADO DO EXERCÍCIO DE 2004

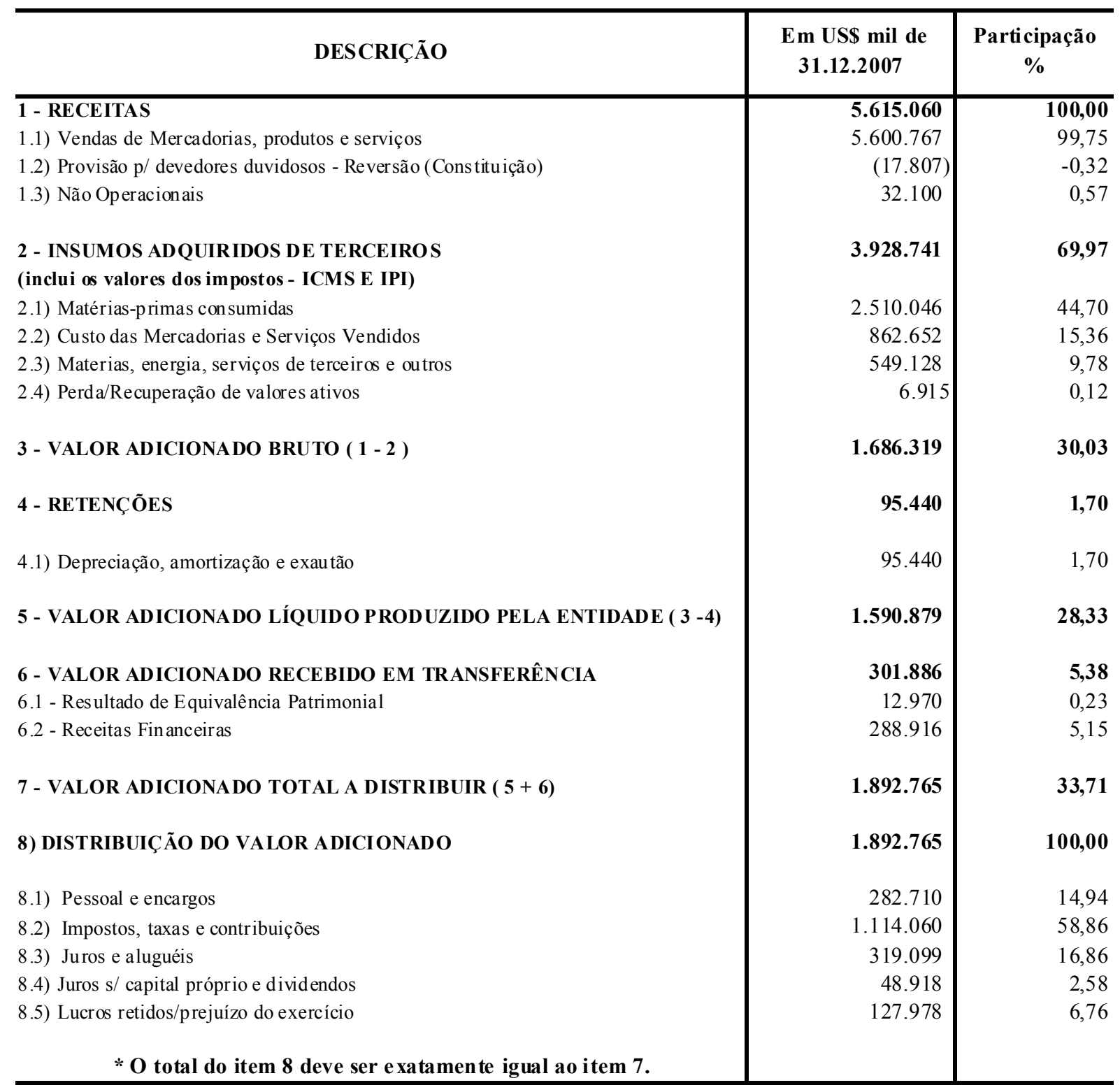


APÊNDICE 8 - DVA CONSOLIDADA DAS EMPRESAS DA ZONA FRANCA DE

MANAUS - 2003 A 2007

DEMONSTRAÇÃO DO VALOR ADICIONADO DO EXERCÍCIO DE 2005

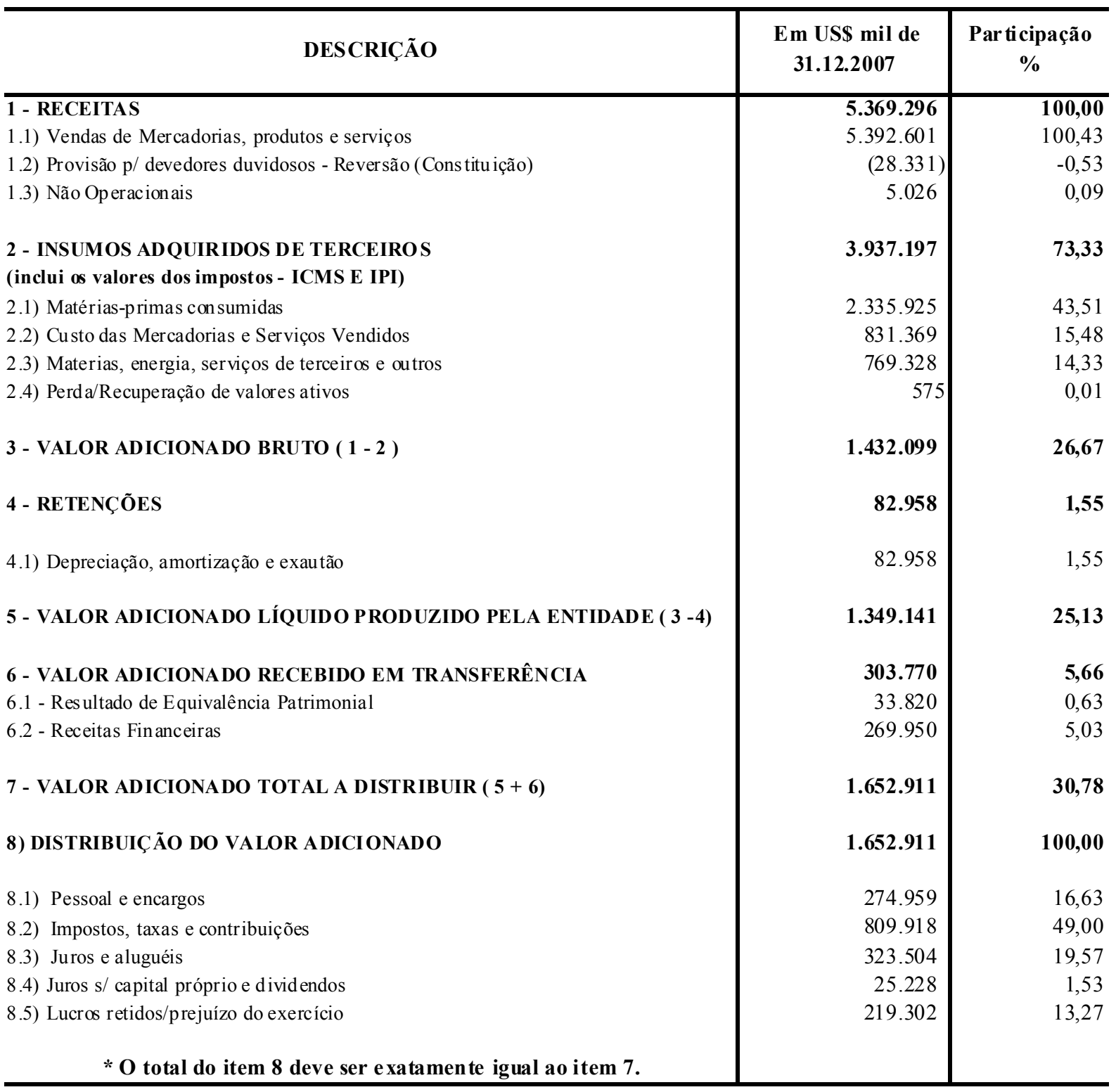


APÊNDICE 8 - DVA CONSOLIDADA DAS EMPRESAS DA ZONA FRANCA DE MANAUS - 2003 A 2007

DEMONSTRAÇÃO DO VALOR ADICIONADO DO EXERCÍCIO DE 2006

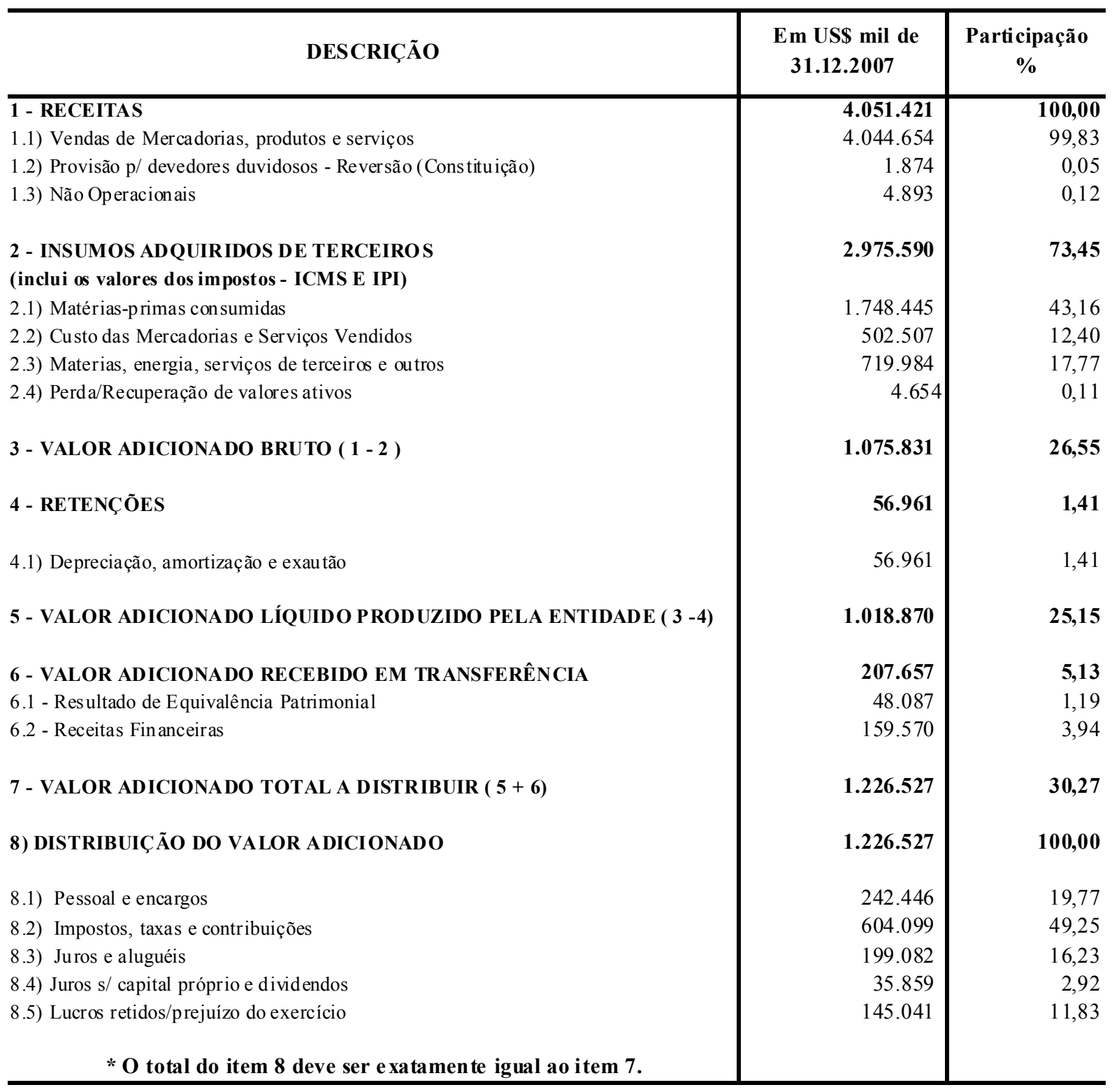


APÊNDICE 8 - DVA CONSOLIDADA DAS EMPRESAS DA ZONA FRANCA DE

MANAUS - 2003 A 2007

DEMONSTRAÇÃO DO VALOR ADICIONADO DO EXERCÍCIO DE 2007

\begin{tabular}{|c|c|c|}
\hline DESCRIÇÃO & $\begin{array}{l}\text { Em US\$ mil de } \\
\text { 31.12.2007 }\end{array}$ & $\begin{array}{l}\text { Participação } \\
\%\end{array}$ \\
\hline $\begin{array}{l}\text { - RECEITAS } \\
\text { 1.1) Vendas de Mercadorias, produtos e serviços } \\
\text { 1.2) Provisão p/ devedores duvidosos - Reversão (Cons titu ição) } \\
\text { 1.3) Não Operacionais }\end{array}$ & $\begin{array}{r}\mathbf{3 . 8 7 1 . 4 5 2} \\
3.895 .075 \\
(25.514) \\
1.891\end{array}$ & $\begin{array}{r}\mathbf{1 0 0 , 0 0} \\
100,61 \\
-0,66 \\
0,05\end{array}$ \\
\hline $\begin{array}{l}2 \text { - INSUMOS ADQUIRIDOS DE TERCEIROS } \\
\text { (inclui os valor es dos impostos - ICMS E IPI) }\end{array}$ & 2.795.541 & 72,21 \\
\hline 2.1) Matérias-primas con sumidas & 1.588 .458 & 41,03 \\
\hline 2.2) Custo das Mercadorias e Serviços Vendidos & 746.193 & 19,27 \\
\hline 2.3) Materias, energia, serviços de terceiros e outros & 449.092 & 11,60 \\
\hline 2.4) Perda/Recuperação de valores ativos & 11.798 & 0,30 \\
\hline 3 - VALOR ADICIONADO BRUTO ( 1 - 2 ) & 1.075.911 & 27,79 \\
\hline 4 - RETENÇÕES & 66.311 & 1,71 \\
\hline 4.1) Depreciação, amortização e exau tão & 66.311 & 1,71 \\
\hline 5 - VALOR ADICIONADO LÍQUIDO PRODUZIDO PELA ENTIDADE ( 3 -4) & 1.009.600 & 26,08 \\
\hline 6 - VALOR ADICIONADO RECEBIDO EM TRANSFERÊNCIA & 188.701 & 4,87 \\
\hline 6.1 - Resultado de Equivalência Patrimonial & 30.277 & 0,78 \\
\hline 6.2 - Receitas Financeiras & 158.424 & 4,09 \\
\hline 7 - VALOR ADICIONADO TOTAL A DISTRIBUIR ( $5+6)$ & 1.198.301 & 30,95 \\
\hline 8) DISTRIBUIÇÃO DO VALOR ADICIONADO & 1.198.301 & 100,00 \\
\hline 8.1) Pessoal e encargos & 229.341 & 19,14 \\
\hline 8.2) Impostos, taxas e contribuições & 703.083 & 58,67 \\
\hline 8.3) Juros e aluguéis & 135.125 & 11,28 \\
\hline 8.4) Juros s/ capital próprio e dividendos & 56.274 & 4,70 \\
\hline 8.5) Lucros retidos/prejuízo do exercício & 74.478 & 6,22 \\
\hline
\end{tabular}





\section{APÊNDICE 9 - DVA CONSOLIDADA DAS EMPRESAS DA ZONA FRANCA DE MANAUS QUE CONTABILIZAM OS INCENTIVOS DE FORMA CORRETA 2003 A 2007}

DEMONSTRAÇÃO DO VALOR ADICIONADO DO EXERCÍCIO DE 2003

\begin{tabular}{|c|c|c|}
\hline DESCRIÇÃO & $\begin{array}{l}\text { Em US\$ mil de } \\
\text { 31.12.2007 }\end{array}$ & $\begin{array}{l}\text { Participação } \\
\%\end{array}$ \\
\hline $\begin{array}{l}\text { 1 - RECEITAS } \\
\text { 1.1) Vendas de Mercadorias, produtos e serviços } \\
\text { 1.2) Provisão p/ devedores duvidosos - Reversão (Constituição) } \\
\text { 1.3) Não Operacionais }\end{array}$ & $\begin{array}{c}1.335 .005 \\
1.348 .555 \\
(16.911) \\
3.361\end{array}$ & $\begin{array}{r}\mathbf{1 0 0 , 0 0} \\
101,01 \\
-1,27 \\
0,25\end{array}$ \\
\hline $\begin{array}{l}2 \text { - INSUMOS ADQUIRIDOS DE TERCEIROS } \\
\text { (inclui os valores dos impostos - ICMS E IPI) }\end{array}$ & 979.776 & 73,39 \\
\hline 2.1) Matérias-primas con sumidas & 612.297 & 45,86 \\
\hline 2.2) Custo das Mercadorias e Serviços Vendidos & 15.948 & 1,19 \\
\hline 2.3) Materias, energia, serviços de terceiros e outros & 348.613 & 26,11 \\
\hline 2.4) Perda/Recuperação de valores ativos & 2.918 & 0,22 \\
\hline 3 - VALOR ADICIONADO BRUTO ( 1 - 2 ) & 355.229 & 26,61 \\
\hline 4 - RETENÇÕES & 35.206 & 2,64 \\
\hline 4.1) Depreciação, amortização e exau tão & 35.206 & 2,64 \\
\hline 5 - VALOR ADICIONADO LÍQUIDO PRODUZIDO PELA ENTIDADE ( 3 -4) & 320.023 & 23,97 \\
\hline 6 - VALOR ADICIONADO RECEBIDO EM TRANSFERÊNCIA & 118.713 & 8,89 \\
\hline 6.1 - Resultado de Equivalência Patrimonial & 4.082 & 0,31 \\
\hline 6.2 - Receitas Financeiras & 114.631 & 8,59 \\
\hline 7 - VALOR ADICIONADO TOTAL A DISTRIBUIR ( 5 + 6) & 438.736 & 32,86 \\
\hline 8) DISTRIBUIÇÃO DO VALOR ADICIONADO & 438.736 & 100,00 \\
\hline 8.1) Pessoal e encargos & 59.199 & 13,49 \\
\hline 8.2) Impostos, taxas e contribuições & 206.671 & 47,11 \\
\hline 8.3) Juros e aluguéis & 57.617 & 13,13 \\
\hline 8.4) Juros s/ capital próprio e dividendos & - & 0,00 \\
\hline 8.5) Lucros retidos/prejuízo do exercício & 115.249 & 26,27 \\
\hline
\end{tabular}




\section{APÊNDICE 9 - DVA CONSOLIDADA DAS EMPRESAS DA ZONA FRANCA DE MANAUS QUE CONTABILIZAM OS INCENTIVOS DE FORMA CORRETA 2003 A 2007}

DEMONSTRAÇÃO DO VALOR ADICIONADO DO EXERCÍCIO DE 2004

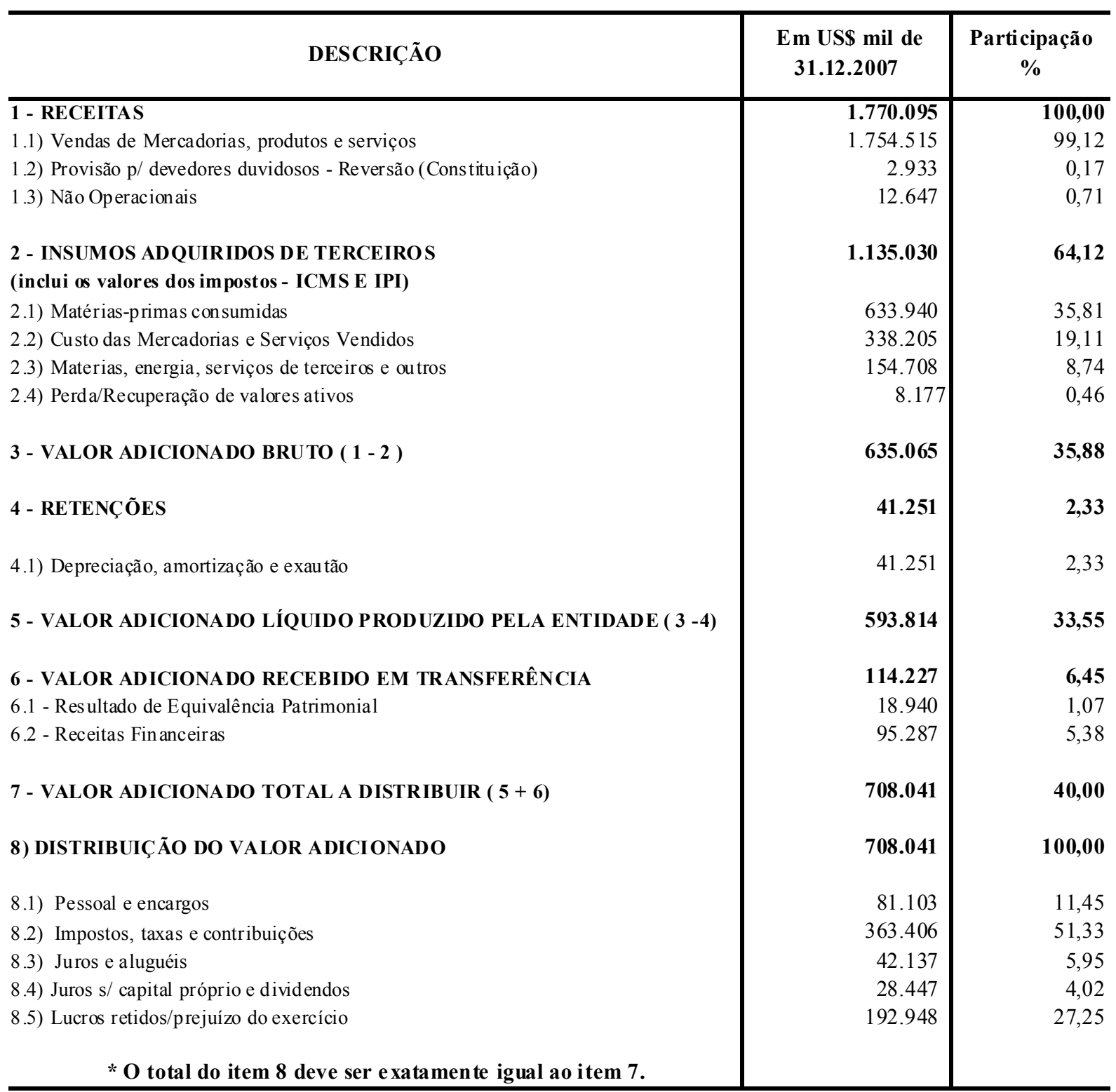




\section{APÊNDICE 9 - DVA CONSOLIDADA DAS EMPRESAS DA ZONA FRANCA DE MANAUS QUE CONTABILIZAM OS INCENTIVOS DE FORMA CORRETA 2003 A 2007}

DEMONSTRAÇÃO DO VALOR ADICIONADO DO EXERCÍCIO DE 2005

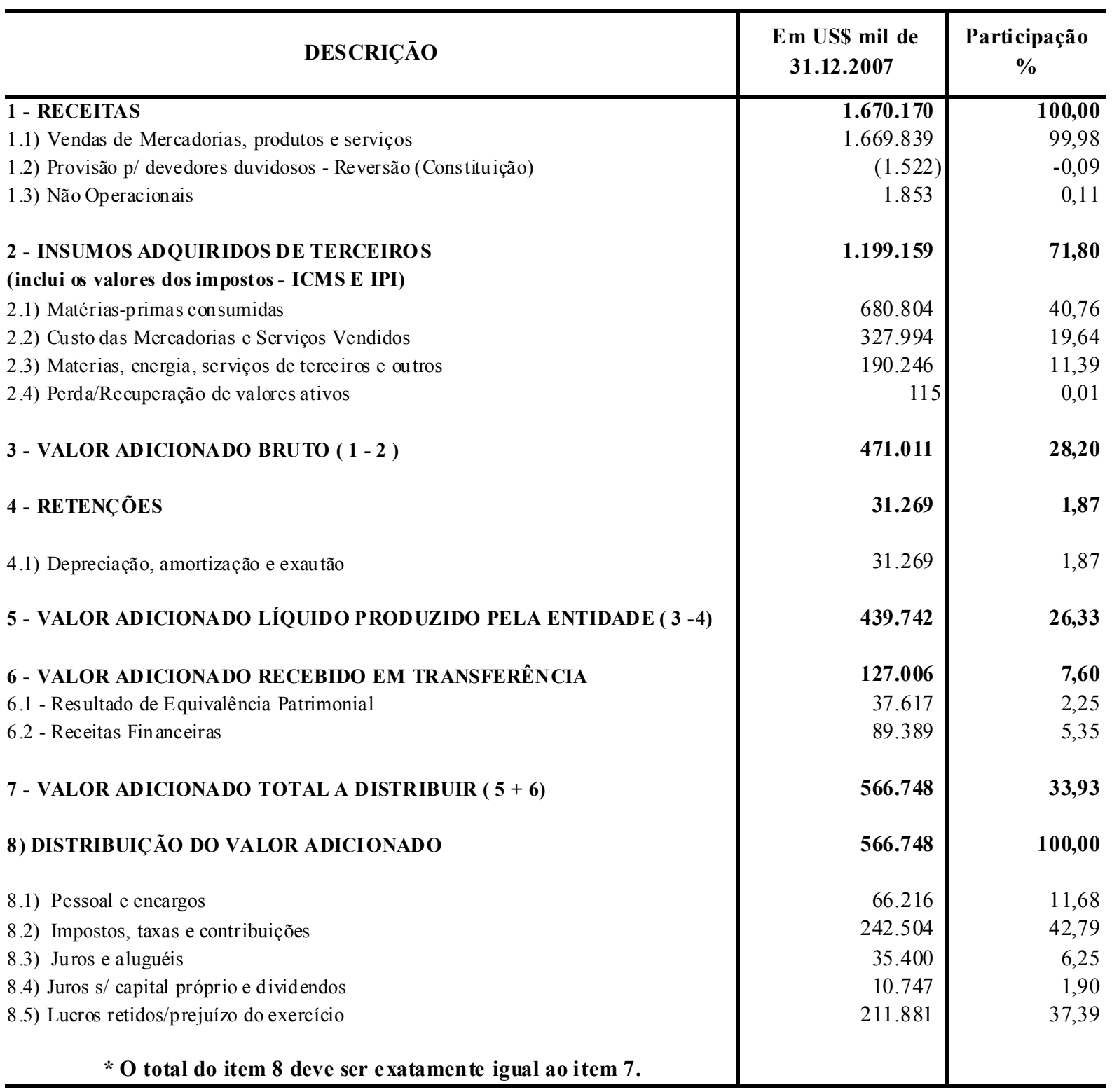




\section{APÊNDICE 9 - DVA CONSOLIDADA DAS EMPRESAS DA ZONA FRANCA DE MANAUS QUE CONTABILIZAM OS INCENTIVOS DE FORMA CORRETA 2003 A 2007}

DEMONSTRAÇÃO DO VALOR ADICIONADO DO EXERCÍCIO DE 2006

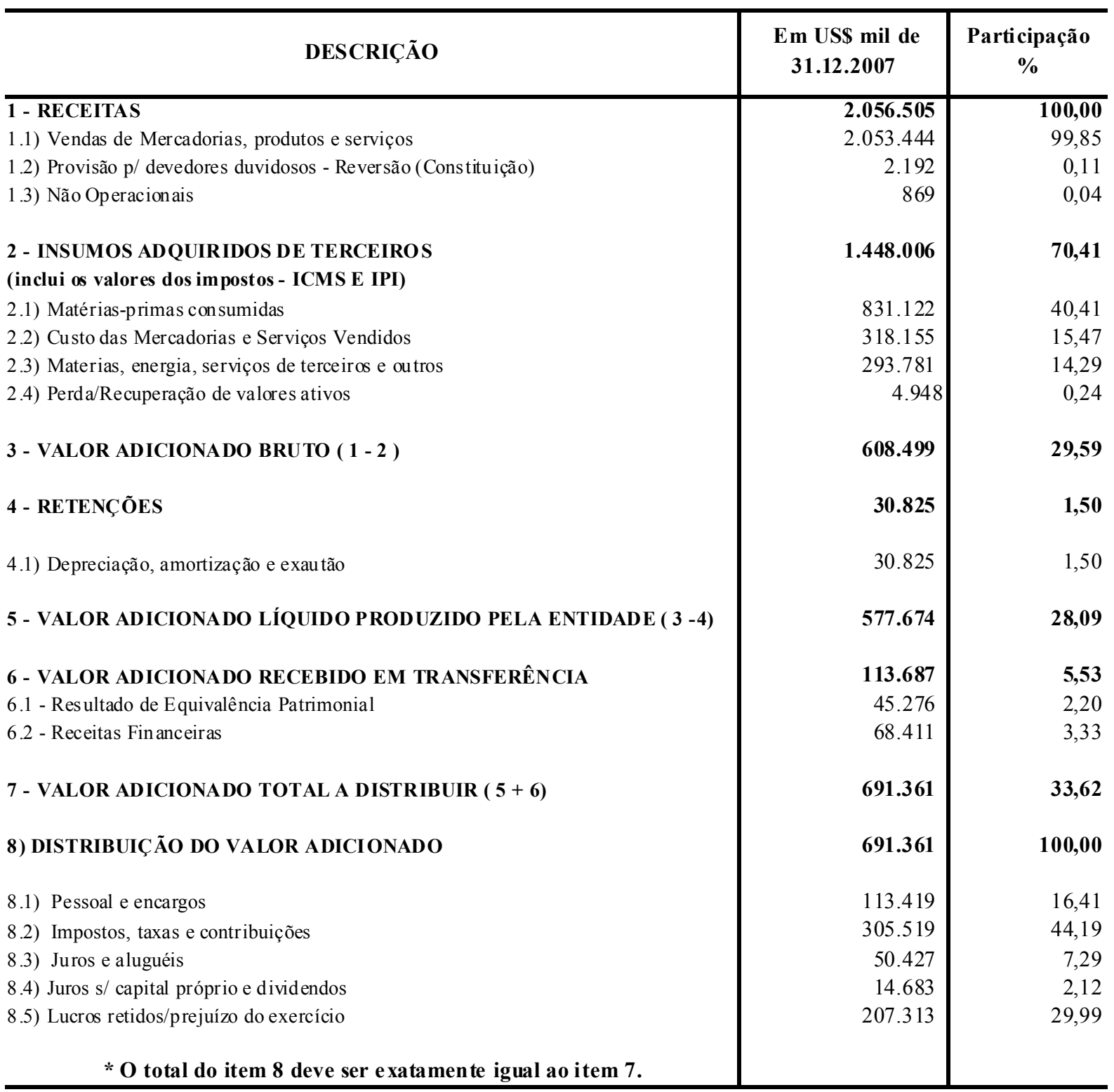




\section{APÊNDICE 9 - DVA CONSOLIDADA DAS EMPRESAS DA ZONA FRANCA DE MANAUS QUE CONTABILIZAM OS INCENTIVOS DE FORMA CORRETA 2003 A 2007}

DEMONSTRAÇÃO DO VALOR ADICIONADO DO EXERCÍCIO DE 2007

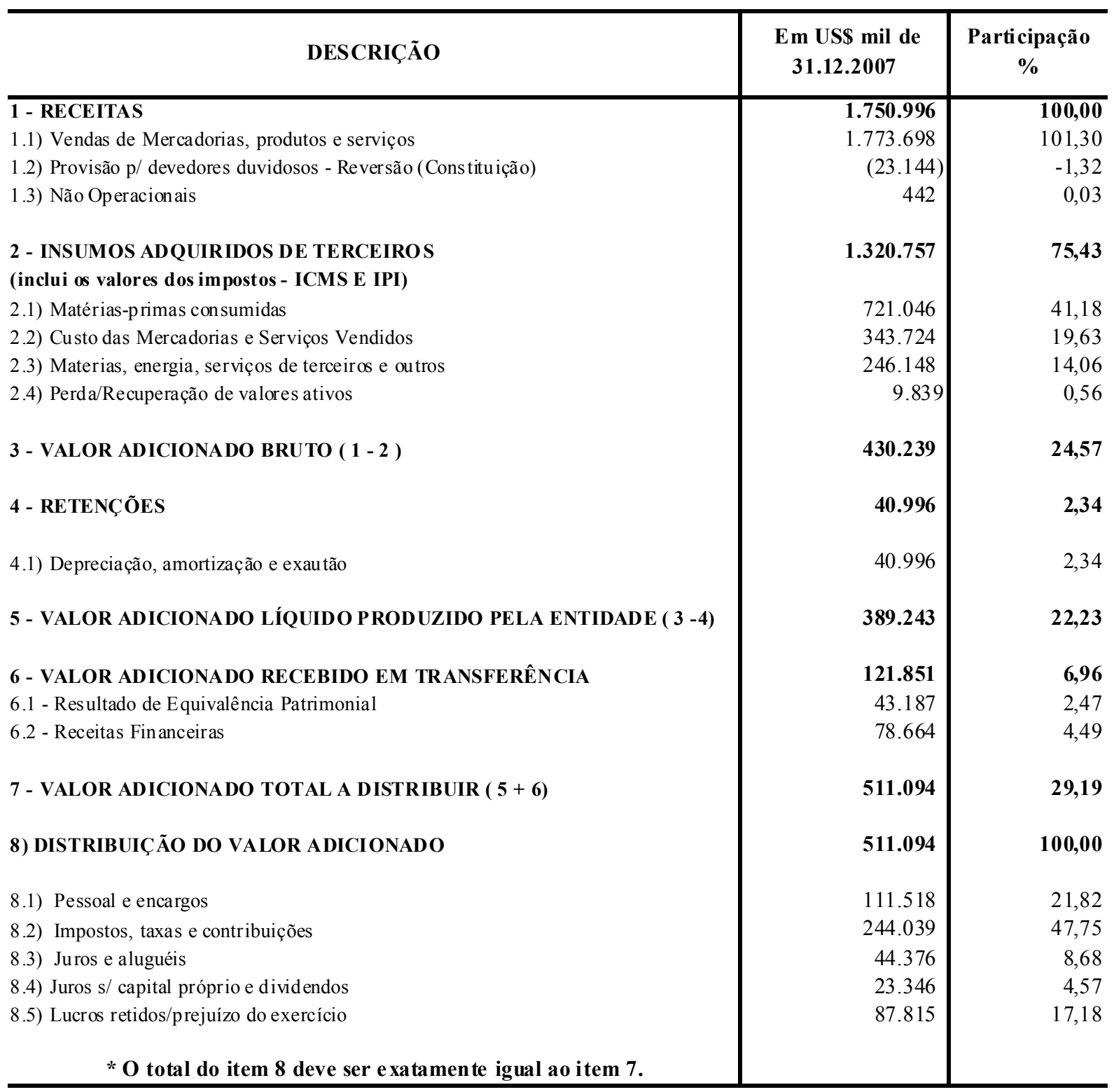





\section{APÊNDICE 10 - DVA CONSOLIDADA DAS EMPRESAS DA ZONA FRANCA DE MANAUS QUE CONTABILIZAM OS INCENTIVOS DE FORMA ERRADA 2003 A 2007}

DEMONSTRAÇÃO DO VALOR ADICIONADO DO EXERCÍCIO DE 2003

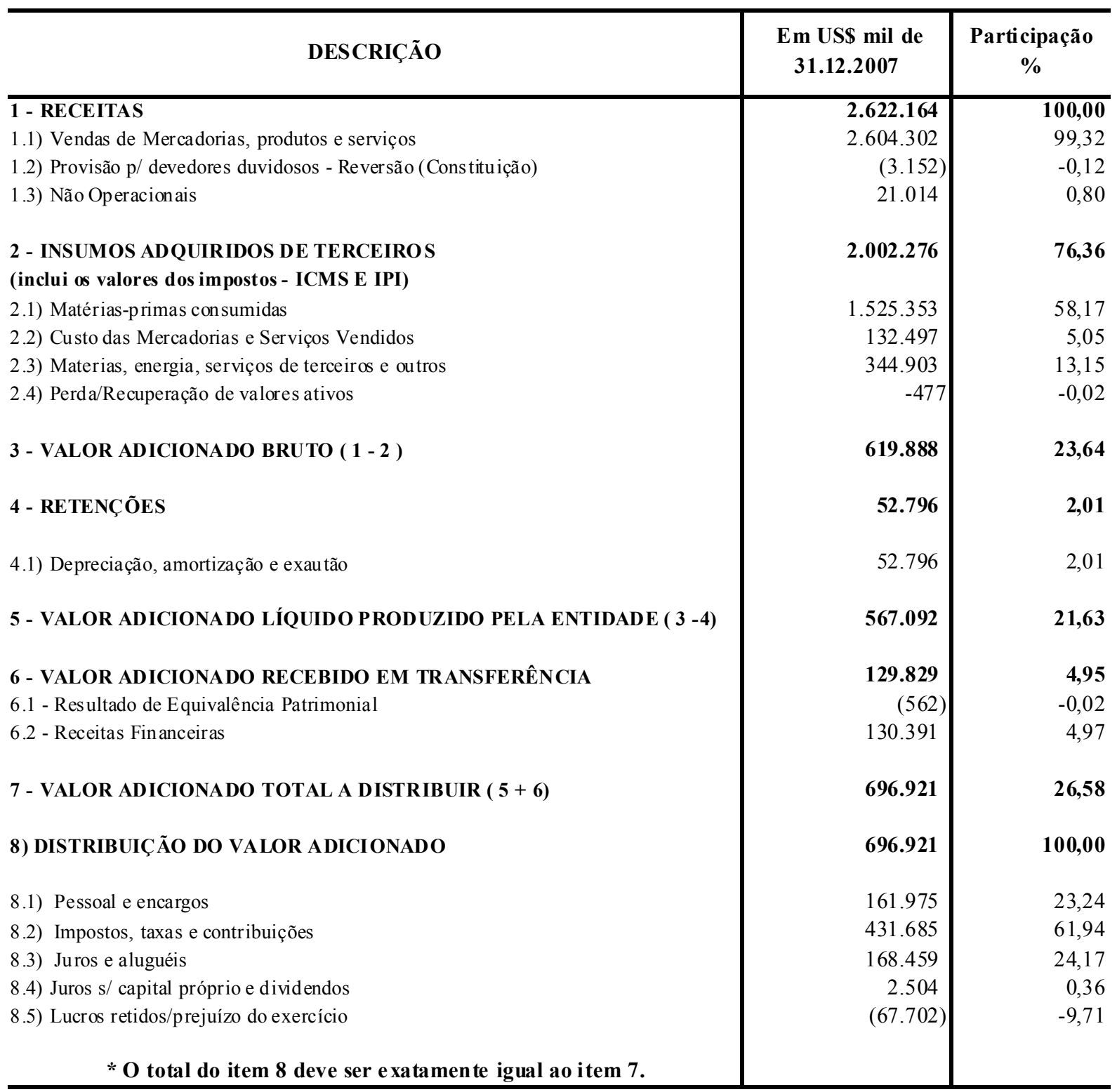




\section{APÊNDICE 10 - DVA CONSOLIDADA DAS EMPRESAS DA ZONA FRANCA DE MANAUS QUE CONTABILIZAM OS INCENTIVOS DE FORMA ERRADA 2003 A 2007}

DEMONSTRAÇÃO DO VALOR ADICIONADO DO EXERCÍCIO DE 2004

\begin{tabular}{|c|c|c|}
\hline DESCRIÇÃO & $\begin{array}{l}\text { Em US\$ mil de } \\
\text { 31.12.2007 }\end{array}$ & $\begin{array}{l}\text { Participação } \\
\text { \% }\end{array}$ \\
\hline $\begin{array}{l}\text { 1 - RECEITAS } \\
\text { 1.1) Vendas de Mercadorias, produtos e serviços } \\
\text { 1.2) Provisão p/ devedores duvidosos - Reversão (Constituição) } \\
\text { 1.3) Não Operacionais }\end{array}$ & $\begin{array}{c}\mathbf{3 . 8 4 4 . 9 6 5} \\
3.846 .252 \\
(20.740) \\
19.453\end{array}$ & $\begin{array}{r}\mathbf{1 0 0 , 0 0} \\
100,03 \\
-0,54 \\
0,51\end{array}$ \\
\hline $\begin{array}{l}2 \text { - INSUMOS ADQUIRIDOS DE TERCEIROS } \\
\text { (inclui os valores dos impostos - ICMS E IPI) }\end{array}$ & 2.793.711 & 72,66 \\
\hline $\begin{array}{l}\text { 2.1) Matérias-primas con sumidas } \\
\text { 2.2) Custo das Mercadorias e Serviços Vendidos } \\
\text { 2.3) Materias, energia, serviços de terceiros e outros } \\
\text { 2.4) Perda/Recuperação de valores ativos }\end{array}$ & $\begin{array}{r}1.876 .106 \\
524.447 \\
394.420 \\
-1.262\end{array}$ & $\begin{array}{r}48,79 \\
13,64 \\
10,26 \\
-0,03\end{array}$ \\
\hline 3 - VALOR ADICIONADO BRUTO ( 1 - 2 ) & 1.051 .254 & 27,34 \\
\hline 4 - RETENÇÕES & 54.189 & 1,41 \\
\hline 4.1) Depreciação, amortização e exau tão & 54.189 & 1,41 \\
\hline 5 - VALOR ADICIONADO LÍQUIDO PRODUZIDO PELA ENTIDADE ( 3 -4) & 997.065 & 25,93 \\
\hline $\begin{array}{l}\text { 6 - VALOR ADICIONADO RECEBIDO EM TRANSFERÊNCIA } \\
6.1 \text { - Resultado de Equivalência Patrimonial } \\
6.2 \text { - Receitas Financeiras }\end{array}$ & $\begin{array}{r}\mathbf{1 8 7 . 6 5 9} \\
(5.970) \\
193.629\end{array}$ & $\begin{array}{r}\mathbf{4 , 8 8} \\
-0,16 \\
5,04\end{array}$ \\
\hline 7 - VALOR ADICIONADO TOTAL A DISTRIBUIR ( 5 + 6) & 1.184 .724 & 30,81 \\
\hline 8) DISTRIBUIÇÃO DO VALOR ADICIONADO & 1.184 .724 & 100,00 \\
\hline $\begin{array}{l}\text { 8.1) Pessoal e encargos } \\
\text { 8.2) Impostos, taxas e contribuições } \\
\text { 8.3) Juros e aluguéis } \\
\text { 8.4) Juros s/ capital próprio e dividendos } \\
\text { 8.5) Lucros retidos/prejuízo do exercício }\end{array}$ & $\begin{array}{c}201.607 \\
750.654 \\
276.962 \\
20.471 \\
(64.970)\end{array}$ & $\begin{array}{r}17,02 \\
63,36 \\
23,38 \\
1,73 \\
-5,48\end{array}$ \\
\hline * O total do item 8 deve ser e xatamente igual ao item 7. & & \\
\hline
\end{tabular}




\section{APÊNDICE 10 - DVA CONSOLIDADA DAS EMPRESAS DA ZONA FRANCA DE MANAUS QUE CONTABILIZAM OS INCENTIVOS DE FORMA ERRADA 2003 A 2007}

DEMONSTRAÇÃO DO VALOR ADICIONADO DO EXERCÍCIO DE 2005

\begin{tabular}{|c|c|c|}
\hline DESCRIÇÃO & $\begin{array}{l}\text { Em US\$ mil de } \\
\text { 31.12.2007 }\end{array}$ & $\begin{array}{l}\text { Participação } \\
\text { \% }\end{array}$ \\
\hline $\begin{array}{l}\text { 1 - RECEITAS } \\
\text { 1.1) Vendas de Mercadorias, produtos e serviços } \\
\text { 1.2) Provisão p/ devedores duvidosos - Reversão (Constituição) } \\
\text { 1.3) Não Operacionais }\end{array}$ & $\begin{array}{c}3.699 .126 \\
3.722 .762 \\
(26.809) \\
3.173\end{array}$ & $\begin{array}{r}\mathbf{1 0 0 , 0 0} \\
100,64 \\
-0,72 \\
0,09\end{array}$ \\
\hline $\begin{array}{l}2 \text { - INSUMOS ADQUIRIDOS DE TERCEIROS } \\
\text { (inclui os valores dos impostos - ICMS E IPI) }\end{array}$ & 2.738.038 & 74,02 \\
\hline $\begin{array}{l}\text { 2.1) Matérias-primas con sumidas } \\
\text { 2.2) Custo das Mercadorias e Serviços Vendidos } \\
\text { 2.3) Materias, energia, serviços de terceiros e outros } \\
\text { 2.4) Perda/Recuperação de valores ativos }\end{array}$ & $\begin{array}{r}1.655 .121 \\
503.375 \\
579.082 \\
460\end{array}$ & $\begin{array}{r}44,74 \\
13,61 \\
15,65 \\
0,01\end{array}$ \\
\hline 3 - VALOR ADICIONADO BRUTO ( 1 - 2 ) & 961.088 & 25,98 \\
\hline 4 - RETENÇÕES & 51.689 & 1,40 \\
\hline 4.1) Depreciação, amortização e exau tão & 51.689 & 1,40 \\
\hline 5 - VALOR ADICIONADO LÍQUIDO PRODUZIDO PELA ENTIDADE ( 3 -4) & 909.399 & 24,58 \\
\hline $\begin{array}{l}\text { 6 - VALOR ADICIONADO RECEBIDO EM TRANSFERÊNCIA } \\
6.1 \text { - Resultado de Equivalência Patrimonial } \\
6.2 \text { - Receitas Financeiras }\end{array}$ & $\begin{array}{r}\mathbf{1 7 6 . 7 6 4} \\
(3.797) \\
180.561\end{array}$ & $\begin{array}{r}4,78 \\
-0,10 \\
4,88\end{array}$ \\
\hline 7 - VALOR ADICIONADO TOTAL A DISTRIBUIR ( $5+6$ ) & 1.086 .163 & 29,36 \\
\hline 8) DISTRIBUIÇÃO DO VALOR ADICIONADO & 1.086.163 & 100,00 \\
\hline $\begin{array}{l}\text { 8.1) Pessoal e encargos } \\
\text { 8.2) Impostos, taxas e contribuições } \\
\text { 8.3) Juros e aluguéis } \\
\text { 8.4) Juros s/ capital próprio e dividendos } \\
\text { 8.5) Lucros retidos/prejuízo do exercício }\end{array}$ & $\begin{array}{r}208.743 \\
567.414 \\
288.104 \\
14.481 \\
7.421\end{array}$ & $\begin{array}{r}19,22 \\
52,24 \\
26,52 \\
1,33 \\
0,68\end{array}$ \\
\hline * O total do item 8 deve ser e xatamente igual ao item 7. & & \\
\hline
\end{tabular}




\section{APÊNDICE 10 - DVA CONSOLIDADA DAS EMPRESAS DA ZONA FRANCA DE MANAUS QUE CONTABILIZAM OS INCENTIVOS DE FORMA ERRADA 2003 A 2007}

DEMONSTRAÇÃO DO VALOR ADICIONADO DO EXERCÍCIO DE 2006

\begin{tabular}{|c|c|c|}
\hline DESCRIÇÃO & $\begin{array}{l}\text { Em US\$ mil de } \\
\text { 31.12.2007 }\end{array}$ & $\begin{array}{l}\text { Participação } \\
\text { \% }\end{array}$ \\
\hline $\begin{array}{l}\text { 1 - RECEITAS } \\
\text { 1.1) Vendas de Mercadorias, produtos e serviços } \\
\text { 1.2) Provisão p/ devedores duvidosos - Reversão (Constituição) } \\
\text { 1.3) Não Operacionais }\end{array}$ & $\begin{array}{r}\mathbf{1} .994 .916 \\
1.991 .210 \\
(318) \\
4.024\end{array}$ & $\begin{array}{r}\mathbf{1 0 0 , 0 0} \\
99,81 \\
-0,02 \\
0,20\end{array}$ \\
\hline $\begin{array}{l}2 \text { - INSUMOS ADQUIRIDOS DE TERCEIROS } \\
\text { (inclui os valores dos impostos - ICMS E IPI) }\end{array}$ & 1.527 .584 & 76,57 \\
\hline $\begin{array}{l}\text { 2.1) Matérias-primas con sumidas } \\
\text { 2.2) Custo das Mercadorias e Serviços Vendidos } \\
\text { 2.3) Materias, energia, serviços de terceiros e outros } \\
\text { 2.4) Perda/Recuperação de valores ativos }\end{array}$ & $\begin{array}{r}917.323 \\
184.352 \\
426.203 \\
-294\end{array}$ & $\begin{array}{r}45,98 \\
9,24 \\
21,36 \\
-0,01\end{array}$ \\
\hline 3 - VALOR ADICIONADO BRUTO ( 1 - 2 ) & 467.332 & 23,43 \\
\hline 4 - RETENÇÕES & 26.136 & 1,31 \\
\hline 4.1) Depreciação, amortização e exau tão & 26.136 & 1,31 \\
\hline 5 - VALOR ADICIONADO LÍQUIDO PRODUZIDO PELA ENTIDADE ( 3 -4) & 441.196 & 22,12 \\
\hline $\begin{array}{l}\text { 6 - VALOR ADICIONADO RECEBIDO EM TRANSFERÊNCIA } \\
6.1 \text { - Resultado de Equivalência Patrimonial } \\
6.2 \text { - Receitas Financeiras }\end{array}$ & $\begin{array}{r}93.970 \\
2.811 \\
91.159\end{array}$ & $\begin{array}{l}4,71 \\
0,14 \\
4,57\end{array}$ \\
\hline 7 - VALOR ADICIONADO TOTAL A DISTRIBUIR ( $5+6$ ) & 535.166 & 26,83 \\
\hline 8) DISTRIBUIÇÃO DO VALOR ADICIONADO & 535.166 & 100,00 \\
\hline $\begin{array}{l}\text { 8.1) Pessoal e encargos } \\
\text { 8.2) Impostos, taxas e contribuições } \\
\text { 8.3) Juros e aluguéis } \\
\text { 8.4) Juros s/ capital próprio e dividendos } \\
\text { 8.5) Lucros retidos/prejuízo do exercício }\end{array}$ & $\begin{array}{r}129.027 \\
298.580 \\
148.655 \\
21.176 \\
(62.272)\end{array}$ & $\begin{array}{r}24,11 \\
55,79 \\
27,78 \\
3,96 \\
-11,64\end{array}$ \\
\hline * O total do item 8 deve ser e xatamente igual ao item 7. & & \\
\hline
\end{tabular}




\section{APÊNDICE 10 - DVA CONSOLIDADA DAS EMPRESAS DA ZONA FRANCA DE MANAUS QUE CONTABILIZAM OS INCENTIVOS DE FORMA ERRADA 2003 A 2007}

DEMONSTRAÇÃO DO VALOR ADICIONADO DO EXERCÍCIO DE 2007

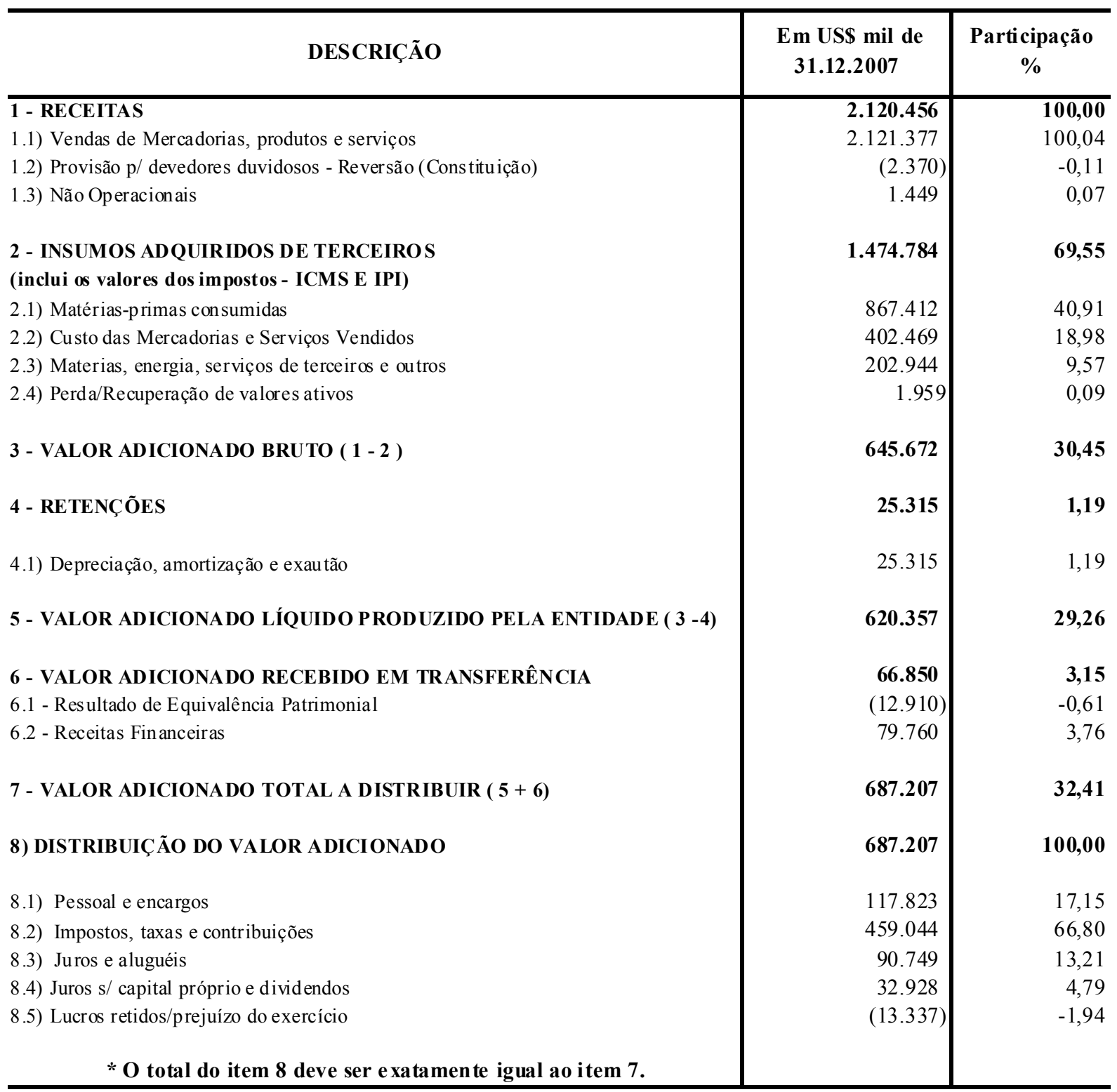



APÊNDICE 11 - DVA CONSOLIDADA DAS EMPRESAS FORA DA ZONA FRANCA

DE MANAUS - TOTAL - 2003 A 2007

DEMONSTRAÇÃO DO VALOR ADICIONADO DO EXERCÍCIO DE 2003

\begin{tabular}{l} 
DESCRIÇÃO \\
\hline 1 - RECEITAS \\
1.1) Vendas de Mercadorias, produtos e serviços \\
1.2) Provisão p/ devedores duvidosos - Reversão (Constituição) \\
1.3) Não Operacionais
\end{tabular}

2 - INSUMOS ADQUIRIDOS DE TERCEIROS

(inclui os valores dos impostos - ICMS E IPI)

2.1) Matérias-primas consumidas

2.2) Custo das Mercadorias e Serviços Vendidos

2.3) Materias, energia, serviços de terceiros e outros

2.4) Perda/Recuperação de valores ativos

3 - VALOR ADICIONADO BRUTO ( 1 - 2 )

\section{4 - RETENÇÕES}

4.1) Depreciação, amortização e exautão

5 - VALOR ADICIONADO LÍQUIDO PRODUZIDO PELA ENTIDADE ( 3 -4)

6 - VALOR ADICIONADO RECEBIDO EM TRANSFERÊNCIA

6.1 - Resultado de Equivalência Patrimonial

6.2 - Receitas Financeiras

7 - VALOR ADICIONADO TOTAL A DISTRIBUIR ( 5 + 6)

8) DISTRIBUIÇÃO DO VALOR ADICIONADO

8.1) Pessoal e encargos

8.2) Impostos, taxas e contribuições

8.3) Juros e aluguéis

8.4) Juros s/ capital próprio e dividendos

8.5) Lucros retidos/prejuízo do exercício

Em US\$ mil de 31.12.2007
Participação $\%$

1.510 .919

1.502 .399

(1.589)

10.109

1.086 .960

787.843

122.428

173.909

2.780

423.959

27.797

27.797

396.162

130.477

9.976

120.501

526.639

526.639

192.218

116.537

107.178

41.105

69.601
100,00

99,44

$-0,11$

0,67

71,94

52,14

8,10

11,51

0,18

28,06

1,84

1,84

26,22

$\mathbf{8 , 6 4}$

0,66

7,98

34,86

100,00

36,50

22,13

20,35

7,81

13,22 


\section{APÊNDICE 11 - DVA CONSOLIDADA DAS EMPRESAS FORA DA ZONA FRANCA DE MANAUS - TOTAL - 2003 A 2007}

\section{DEMONSTRAÇÃO DO VALOR ADICIONADO DO EXERCÍCIO DE 2004}

\begin{tabular}{l} 
DESCRIÇÃO \\
\hline 1 - RECEITAS \\
1.1) Vendas de Mercadorias, produtos e serviços \\
1.2) Provisão p/ devedores duvidosos - Reversão (Constituição) \\
1.3) Não Operacionais
\end{tabular}

2 - INSUMOS ADQUIRIDOS DE TERCEIROS (inclui os valores dos impostos - ICMS E IPI)
2.1) Matérias-primas consumidas
2.2) Custo das Mercadorias e Serviços Vendidos
2.3) Materias, energia, serviços de terceiros e outros
2.4) Perda/Recuperação de valores ativos

3 - VALOR ADICIONADO BRUTO ( 1 - 2 )

4 - RETENÇÕES

4.1) Depreciação, amortização e exautão

\section{5 - VALOR ADICIONADO LÍQUIDO PRODUZIDO PELA ENTIDADE ( 3 -4)}

6 - VALOR ADICIONADO RECEBIDO EM TRANSFERÊNCIA

6.1 - Resultado de Equivalência Patrimonial

6.2 - Receitas Financeiras

\section{7 - VALOR ADICIONADO TOTAL A DISTRIBUIR ( 5 + 6)}

8) DISTRIBUIÇÃO DO VALOR ADICIONADO
8.1) Pessoal e encargos
8.2) Impostos, taxas e contribuições
8.3) Juros e aluguéis
8.4) Juros s/ capital próprio e dividendos
8.5) Lucros retidos/prejuízo do exercício

\begin{tabular}{|c|c|}
\hline $\begin{array}{c}\text { Em US\$ mil de } \\
\text { 31.12.2007 }\end{array}$ & $\begin{array}{c}\text { Participação } \\
\%\end{array}$ \\
\hline 2.408 .361 & 100,00 \\
\hline 2.410 .062 & 100,07 \\
\hline$(2.124)$ & $-0,09$ \\
\hline 423 & 0,02 \\
\hline 1.774 .205 & 73,67 \\
\hline 1.103 .733 & 45,83 \\
\hline 118.907 & 4,94 \\
\hline 544.296 & 22,60 \\
\hline 7.269 & 0,30 \\
\hline 634.156 & 26,33 \\
\hline 34.978 & 1,45 \\
\hline 34.978 & 1,45 \\
\hline 599.178 & 24,88 \\
\hline 155.105 & 6,44 \\
\hline 54.317 & 2,26 \\
\hline 100.788 & 4,18 \\
\hline 754.283 & 31,32 \\
\hline 754.283 & 100,00 \\
\hline 281.698 & 37,35 \\
\hline 185.183 & 24,55 \\
\hline 106.302 & 14,09 \\
\hline 58.355 & 7,74 \\
\hline 122.745 & 16,27 \\
\hline
\end{tabular}




\section{APÊNDICE 11 - DVA CONSOLIDADA DAS EMPRESAS FORA DA ZONA FRANCA DE MANAUS - TOTAL - 2003 A 2007}

\section{DEMONSTRAÇÃO DO VALOR ADICIONADO DO EXERCÍCIO DE 2005}

\begin{tabular}{l} 
DESCRIÇÃO \\
\hline 1 - RECEITAS \\
1.1) Vendas de Mercadorias, produtos e serviços \\
1.2) Provisão p/ devedores duvidosos - Reversão (Constituição) \\
1.3) Não Operacionais
\end{tabular}

2 - INSUMOS ADQUIRIDOS DE TERCEIROS (inclui os valores dos impostos - ICMS E IPI)
2.1) Matérias-primas consumidas
2.2) Custo das Mercadorias e Serviços Vendidos
2.3) Materias, energia, serviços de terceiros e outros
2.4) Perda/Recuperação de valores ativos

3 - VALOR ADICIONADO BRUTO ( 1 - 2 )

4 - RETENÇÕES

4.1) Depreciação, amortização e exautão

\section{5 - VALOR ADICIONADO LÍQUIDO PRODUZIDO PELA ENTIDADE ( 3 -4)}

6 - VALOR ADICIONADO RECEBIDO EM TRANSFERÊNCIA

6.1 - Resultado de Equivalência Patrimonial

6.2 - Receitas Financeiras

\section{7 - VALOR ADICIONADO TOTAL A DISTRIBUIR ( 5 + 6)}

8) DISTRIBUIÇÃO DO VALOR ADICIONADO
8.1) Pessoal e encargos
8.2) Impostos, taxas e contribuições
8.3) Juros e aluguéis
8.4) Juros s/ capital próprio e dividendos
8.5) Lucros retidos/prejuízo do exercício

\begin{tabular}{|c|c|}
\hline $\begin{array}{c}\text { Em US\$ mil de } \\
\text { 31.12.2007 }\end{array}$ & $\begin{array}{c}\text { Participação } \\
\%\end{array}$ \\
\hline 10.730 .050 & 100,00 \\
\hline 10.753 .925 & 100,22 \\
\hline (41.207) & $-0,38$ \\
\hline 17.332 & 0,16 \\
\hline 5.522.407 & 51,47 \\
\hline 2.219 .848 & 20,69 \\
\hline 1.976 .718 & 18,42 \\
\hline 1.324 .280 & 12,34 \\
\hline 1.561 & 0,01 \\
\hline 5.207 .643 & 48,53 \\
\hline 152.716 & 1,42 \\
\hline 152.716 & 1,42 \\
\hline 5.054 .927 & 47,11 \\
\hline 336.600 & 3,14 \\
\hline 56.675 & 0,53 \\
\hline 279.925 & 2,61 \\
\hline 5.391.527 & 50,25 \\
\hline 5.391.527 & 100,00 \\
\hline 620.639 & 11,51 \\
\hline 3.623 .110 & 67,20 \\
\hline 285.435 & 5,29 \\
\hline 677.366 & 12,56 \\
\hline 184.977 & 3,43 \\
\hline
\end{tabular}




\section{APÊNDICE 11 - DVA CONSOLIDADA DAS EMPRESAS FORA DA ZONA FRANCA DE MANAUS - TOTAL - 2003 A 2007}

\section{DEMONSTRAÇÃO DO VALOR ADICIONADO DO EXERCÍCIO DE 2006}

\begin{tabular}{l} 
DESCRIÇÃO \\
\hline 1 - RECEITAS \\
1.1) Vendas de Mercadorias, produtos e serviços \\
1.2) Provisão p/ devedores duvidosos - Reversão (Constituição) \\
1.3) Não Operacionais
\end{tabular}

\section{2 - INSUMOS ADQUIRIDOS DE TERCEIROS}

(inclui os valores dos impostos - ICMS E IPI)
2.1) Matérias-primas consumidas
2.2) Custo das Mercadorias e Serviços Vendidos

2.3) Materias, energia, serviços de terceiros e outros

2.4) Perda/Recuperação de valores ativos

3 - VALOR ADICIONADO BRUTO ( 1 - 2 )

\section{4 - RETENÇÕES}

4.1) Depreciação, amortização e exautão

\section{5 - VALOR ADICIONADO LÍQUIDO PRODUZIDO PELA ENTIDADE ( 3 -4)}

\section{6 - VALOR ADICIONADO RECEBIDO EM TRANSFERÊNCIA}

6.1 - Resultado de Equivalência Patrimonial

6.2 - Receitas Financeiras

\section{7 - VALOR ADICIONADO TOTAL A DISTRIBUIR ( 5 + 6)}

\section{8) DISTRIBUIÇÃO DO VALOR ADICIONADO}
8.1) Pessoal e encargos
8.2) Impostos, taxas e contribuições
8.3) Juros e aluguéis
8.4) Juros s/ capital próprio e dividendos
8.5) Lucros retidos/prejuízo do exercício

\begin{tabular}{|c|c|}
\hline $\begin{array}{c}\text { Em US\$ mil de } \\
\text { 31.12.2007 }\end{array}$ & $\begin{array}{c}\text { Participação } \\
\%\end{array}$ \\
\hline 11.879 .128 & 100,00 \\
\hline 11.910 .409 & 100,26 \\
\hline$(46.081)$ & $-0,39$ \\
\hline 14.800 & 0,12 \\
\hline 5.956 .678 & 50,14 \\
\hline 2.839 .728 & 23,91 \\
\hline 1.351 .581 & 11,38 \\
\hline 1.731 .890 & 14,58 \\
\hline 33.479 & 0,28 \\
\hline 5.922 .450 & 49,86 \\
\hline 176.596 & 1,49 \\
\hline 176.596 & 1,49 \\
\hline 5.745 .854 & 48,37 \\
\hline 471.974 & 3,97 \\
\hline 103.525 & 0,87 \\
\hline 368.449 & 3,10 \\
\hline 6.217 .828 & 52,34 \\
\hline 6.217 .828 & 100,00 \\
\hline 801.154 & 12,88 \\
\hline 4.038 .977 & 64,96 \\
\hline 399.183 & 6,42 \\
\hline 800.178 & 12,87 \\
\hline 178.336 & 2,87 \\
\hline
\end{tabular}




\section{APÊNDICE 11 - DVA CONSOLIDADA DAS EMPRESAS FORA DA ZONA FRANCA DE MANAUS - TOTAL - 2003 A 2007}

\section{DEMONSTRAÇÃO DO VALOR ADICIONADO DO EXERCÍCIO DE 2007}

\begin{tabular}{l} 
DESCRIÇÃO \\
\hline 1 - RECEITAS \\
1.1) Vendas de Mercadorias, produtos e serviços \\
1.2) Provisão p/ devedores duvidosos - Reversão (Constituição) \\
1.3) Não Operacionais
\end{tabular}

2 - INSUMOS ADQUIRIDOS DE TERCEIROS (inclui os valores dos impostos - ICMS E IPI)
2.1) Matérias-primas consumidas
2.2) Custo das Mercadorias e Serviços Vendidos
2.3) Materias, energia, serviços de terceiros e outros
2.4) Perda/Recuperação de valores ativos

3 - VALOR ADICIONADO BRUTO ( 1 - 2 )

4 - RETENÇÕES

4.1) Depreciação, amortização e exautão

5 - VALOR ADICIONADO LÍQUIDO PRODUZIDO PELA ENTIDADE ( 3 -4)

6 - VALOR ADICIONADO RECEBIDO EM TRANSFERÊNCIA

6.1 - Resultado de Equivalência Patrimonial

6.2 - Receitas Financeiras

\section{7 - VALOR ADICIONADO TOTAL A DISTRIBUIR ( 5 + 6)}

8) DISTRIBUIÇÃO DO VALOR ADICIONADO
8.1) Pessoal e encargos
8.2) Impostos, taxas e contribuições
8.3) Juros e aluguéis
8.4) Juros s/ capital próprio e dividendos
8.5) Lucros retidos/prejuízo do exercício

\begin{tabular}{|c|c|}
\hline $\begin{array}{c}\text { Em US\$ mil de } \\
\text { 31.12.2007 }\end{array}$ & $\begin{array}{c}\text { Participação } \\
\%\end{array}$ \\
\hline 12.243 .100 & 100,00 \\
\hline 12.245 .933 & 100,02 \\
\hline (28.904) & $-0,24$ \\
\hline 26.071 & 0,21 \\
\hline 5.848 .200 & 47,77 \\
\hline 2.328 .960 & 19,02 \\
\hline 1.657 .379 & 13,54 \\
\hline 1.806 .052 & 14,75 \\
\hline 55.809 & 0,46 \\
\hline 6.394 .900 & 52,23 \\
\hline 172.251 & 1,41 \\
\hline 172.251 & 1,41 \\
\hline 6.222 .649 & 50,83 \\
\hline 382.390 & 3,12 \\
\hline 33.974 & 0,28 \\
\hline 348.416 & 2,85 \\
\hline 6.605.039 & 53,95 \\
\hline 6.605.039 & 100,00 \\
\hline 933.082 & 14,13 \\
\hline 4.313 .105 & 65,30 \\
\hline 322.888 & 4,89 \\
\hline 830.961 & 12,58 \\
\hline 205.003 & 3,10 \\
\hline
\end{tabular}



APÊNDICE 12 - DVA CONSOLIDADA DAS EMPRESAS FORA DA ZONA FRANCA DE MANAUS - SETOR AUTOINDÚSTRIA - 2003 A 2007

DEMONSTRAÇÃO DO VALOR ADICIONADO DO EXERCÍCIO DE 2003

\begin{tabular}{|c|c|c|}
\hline DESCRIÇÃO & $\begin{array}{l}\text { Em US\$ mil de } \\
\text { 31.12.2007 }\end{array}$ & $\begin{array}{l}\text { Participação } \\
\%\end{array}$ \\
\hline $\begin{array}{l}\text { - RECEITAS } \\
\text { 1.1) Vendas de Mercadorias, produtos e serviços } \\
\text { 1.2) Provisão p/ devedores duvidosos - Reversão (Cons tituição) } \\
\text { 1.3) Não Operacionais }\end{array}$ & $\begin{array}{r}\mathbf{9 8 9 . 1 1 1} \\
979.864 \\
(862) \\
10.109\end{array}$ & $\begin{array}{r}\mathbf{1 0 0 , 0 0} \\
99,07 \\
-0,09 \\
1,02\end{array}$ \\
\hline $\begin{array}{l}2 \text { - INSUMOS ADQUIRIDOS DE TERCEIROS } \\
\text { (inclui os valores dos impostos - ICMS E IPI) }\end{array}$ & 707.779 & 71,56 \\
\hline $\begin{array}{l}\text { 2.1) Matérias-primas con sumidas } \\
\text { 2.2) Custo das Mercadorias e Serviços Vendidos } \\
\text { 2.3) Materias, energia, serviços de terceiros e outros } \\
\text { 2.4) Perda/Recuperação de valores ativos }\end{array}$ & $\begin{array}{r}535.322 \\
37.947 \\
132.472 \\
2.038\end{array}$ & $\begin{array}{r}54,12 \\
3,84 \\
13,39 \\
0,21\end{array}$ \\
\hline 3 - VALOR ADICIONADO BRUTO ( 1 - 2 ) & 281.332 & 28,44 \\
\hline 4 - RETENÇÕES & 16.098 & 1,63 \\
\hline 4.1) Depreciação, amortização e exau tão & 16.098 & 1,63 \\
\hline 5 - VALOR ADICIONADO LÍQUIDO PRODUZIDO PELA ENTIDADE ( 3 -4) & 265.234 & 26,82 \\
\hline $\begin{array}{l}\text { 6 - VALOR ADICIONADO RECEBIDO EM TRANSFERÊNCIA } \\
6.1 \text { - Resultado de Equivalência Patrimonial } \\
6.2 \text { - Receitas Financeiras }\end{array}$ & $\begin{array}{r}110.532 \\
9.976 \\
100.556\end{array}$ & $\begin{array}{r}11,17 \\
1,01 \\
10,17\end{array}$ \\
\hline 7 - VALOR ADICIONADO TOTAL A DISTRIBUIR $(5+6)$ & 375.766 & 37,99 \\
\hline 8) DISTRIBUIÇÃO DO VALOR ADICIONADO & 375.766 & 100,00 \\
\hline $\begin{array}{l}\text { 8.1) Pessoal e encargos } \\
\text { 8.2) Impostos, taxas e contribuições } \\
\text { 8.3) Juros e aluguéis } \\
\text { 8.4) Juros s/ capital próprio e dividendos } \\
\text { 8.5) Lucros retidos/prejuízo do exercício }\end{array}$ & $\begin{array}{r}151.781 \\
54.101 \\
88.098 \\
41.105 \\
40.681\end{array}$ & $\begin{array}{l}40,39 \\
14,40 \\
23,44 \\
10,94 \\
10,83\end{array}$ \\
\hline * O total do item 8 deve ser e xatamente igual ao item 7. & & \\
\hline
\end{tabular}


APÊNDICE 12 - DVA CONSOLIDADA DAS EMPRESAS FORA DA ZONA FRANCA DE MANAUS - SETOR AUTOINDÚSTRIA - 2003 A 2007

DEMONSTRAÇÃO DO VALOR ADICIONADO DO EXERCÍCIO DE 2004

\begin{tabular}{|c|c|c|}
\hline DESCRIÇÃO & $\begin{array}{l}\text { Em US\$ mil de } \\
\text { 31.12.2007 }\end{array}$ & $\begin{array}{l}\text { Participação } \\
\%\end{array}$ \\
\hline $\begin{array}{l}\text { - RECEITAS } \\
\text { 1.1) Vendas de Mercadorias, produtos e serviços } \\
\text { 1.2) Provisão p/ devedores duvidosos - Reversão (Cons tituição) } \\
\text { 1.3) Não Operacionais }\end{array}$ & $\begin{array}{r}\mathbf{1 . 7 2 7 . 2 0 4} \\
1.728 .208 \\
(1.427) \\
423\end{array}$ & $\begin{array}{r}\mathbf{1 0 0 , 0 0} \\
100,06 \\
-0,08 \\
0,02\end{array}$ \\
\hline $\begin{array}{l}2 \text { - INSUMOS ADQUIRIDOS DE TERCEIROS } \\
\text { (inclui os valores dos impostos - ICMS E IPI) }\end{array}$ & 1.300 .949 & 75,32 \\
\hline $\begin{array}{l}\text { 2.1) Matérias-primas consumidas } \\
\text { 2.2) Custo das Mercadorias e Serviços Vendidos } \\
\text { 2.3) Materias, energia, serviços de terceiros e outros } \\
\text { 2.4) Perda/Recuperação de valores ativos }\end{array}$ & $\begin{array}{r}1.067 .804 \\
116.743 \\
110.416 \\
5.986\end{array}$ & $\begin{array}{r}61,82 \\
6,76 \\
6,39 \\
0,35\end{array}$ \\
\hline 3 - VALOR ADICIONADO BRUTO ( 1 - 2 ) & 426.255 & 24,68 \\
\hline 4 - RETENÇÕES & 19.752 & 1,14 \\
\hline 4.1) Depreciação, amortização e exau tão & 19.752 & 1,14 \\
\hline 5 - VALOR ADICIONADO LÍQUIDO PRODUZIDO PELA ENTIDADE ( 3 -4) & 406.503 & 23,54 \\
\hline $\begin{array}{l}\text { 6 - VALOR ADICIONADO RECEBIDO EM TRANSFERÊNCIA } \\
6.1 \text { - Resultado de Equivalência Patrimonial } \\
6.2 \text { - Receitas Financeiras }\end{array}$ & $\begin{array}{r}147.600 \\
54.317 \\
93.283\end{array}$ & $\begin{array}{l}\mathbf{8 , 5 5} \\
3,14 \\
5,40\end{array}$ \\
\hline 7 - VALOR ADICIONADO TOTAL A DISTRIBUIR $(5+6)$ & 554.103 & 32,08 \\
\hline 8) DISTRIBUIÇÃO DO VALOR ADICIONADO & 554.103 & 100,00 \\
\hline $\begin{array}{l}\text { 8.1) Pessoal e encargos } \\
\text { 8.2) Impostos, taxas e contribuições } \\
\text { 8.3) Juros e aluguéis } \\
\text { 8.4) Juros s/ capital próprio e dividendos } \\
\text { 8.5) Lucros retidos/prejuízo do exercício }\end{array}$ & $\begin{array}{r}228.553 \\
78.282 \\
89.165 \\
56.656 \\
101.447\end{array}$ & $\begin{array}{l}41,25 \\
14,13 \\
16,09 \\
10,22 \\
18,31\end{array}$ \\
\hline * O total do item 8 deve ser exatamente igual ao item 7. & & \\
\hline
\end{tabular}


APÊNDICE 12 - DVA CONSOLIDADA DAS EMPRESAS FORA DA ZONA FRANCA DE MANAUS - SETOR AUTOINDÚSTRIA - 2003 A 2007

DEMONSTRAÇÃO DO VALOR ADICIONADO DO EXERCÍCIO DE 2005

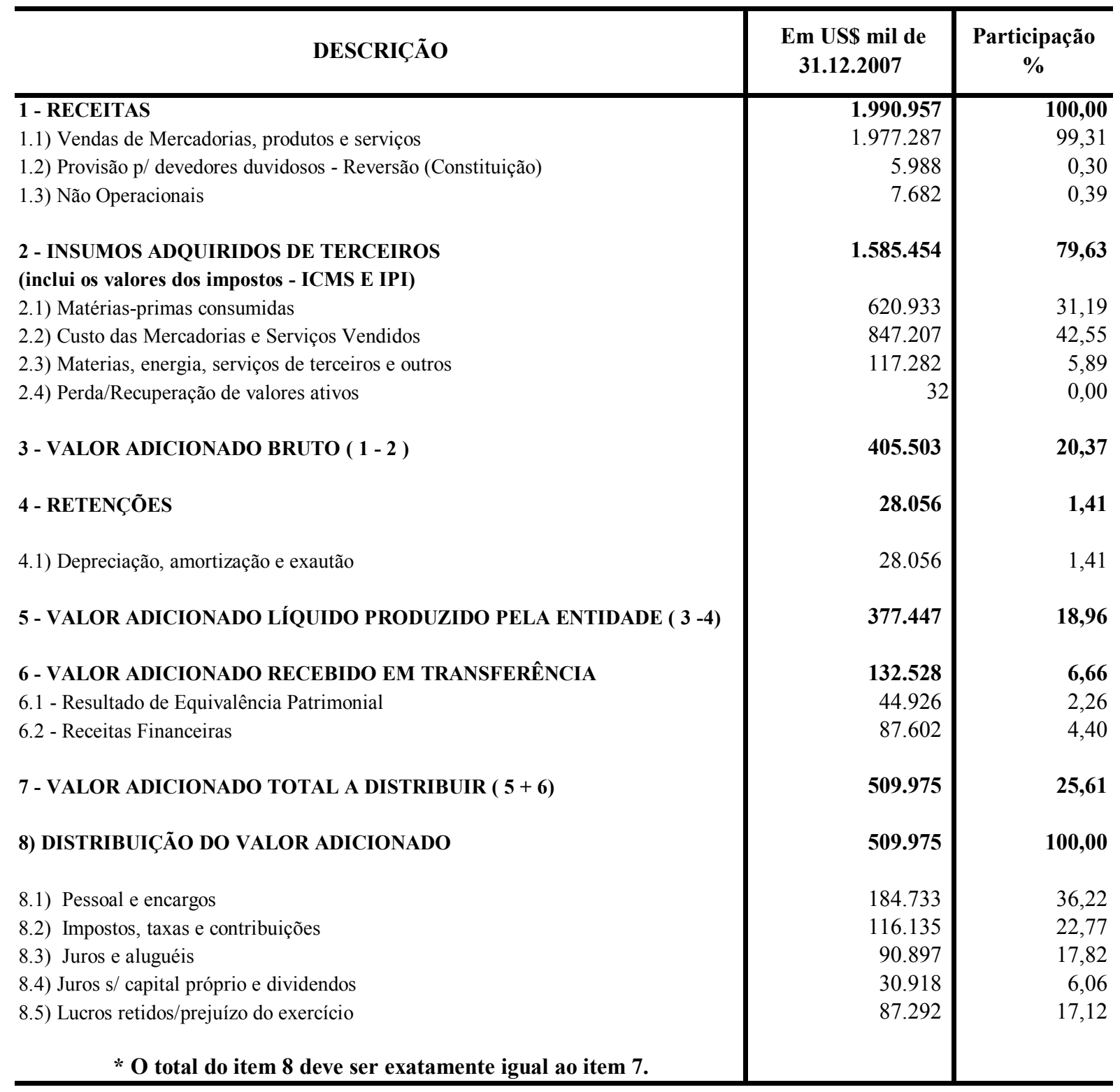


APÊNDICE 12 - DVA CONSOLIDADA DAS EMPRESAS FORA DA ZONA FRANCA DE MANAUS - SETOR AUTOINDÚSTRIA - 2003 A 2007

DEMONSTRAÇÃO DO VALOR ADICIONADO DO EXERCÍCIO DE 2006

\begin{tabular}{|c|c|c|}
\hline DESCRIÇÃO & $\begin{array}{l}\text { Em US\$ mil de } \\
\text { 31.12.2007 }\end{array}$ & $\begin{array}{l}\text { Participação } \\
\text { \% }\end{array}$ \\
\hline $\begin{array}{l}\text { 1 - RECEITAS } \\
\text { 1.1) Vendas de Mercadorias, produtos e serviços } \\
\text { 1.2) Provisão p/ devedores duvidosos - Reversão (Constituição) } \\
\text { 1.3) Não Operacionais }\end{array}$ & $\begin{array}{r}1.024 .072 \\
1.023 .163 \\
(133) \\
1.042\end{array}$ & $\begin{array}{r}\mathbf{1 0 0 , 0 0} \\
99,91 \\
-0,01 \\
0,10\end{array}$ \\
\hline $\begin{array}{l}2 \text { - INSUMOS ADQUIRIDOS DE TERCEIROS } \\
\text { (inclui os valores dos impostos - ICMS E IPI) }\end{array}$ & 737.483 & 72,01 \\
\hline $\begin{array}{l}\text { 2.1) Matérias-primas consumidas } \\
\text { 2.2) Custo das Mercadorias e Serviços Vendidos } \\
\text { 2.3) Materias, energia, serviços de terceiros e outros } \\
\text { 2.4) Perda/Recuperação de valores ativos }\end{array}$ & $\begin{array}{c}630.318 \\
- \\
105.830 \\
1.335\end{array}$ & $\begin{array}{r}61,55 \\
0,00 \\
10,33 \\
0,13\end{array}$ \\
\hline 3 - VALOR ADICIONADO BRUTO ( 1 - 2 ) & 286.589 & 27,99 \\
\hline 4 - RETENÇÕES & 14.277 & 1,39 \\
\hline 4.1) Depreciação, amortização e exautão & 14.277 & 1,39 \\
\hline 5 - VALOR ADICIONADO LÍQUIDO PRODUZIDO PELA ENTIDADE ( 3 -4) & 272.312 & 26,59 \\
\hline $\begin{array}{l}\text { 6 - VALOR ADICIONADO RECEBIDO EM TRANSFERÊNCIA } \\
6.1 \text { - Resultado de Equivalência Patrimonial } \\
6.2 \text { - Receitas Financeiras }\end{array}$ & $\begin{array}{r}103.720 \\
46.051 \\
57.669\end{array}$ & $\begin{array}{r}\mathbf{1 0 , 1 3} \\
4,50 \\
5,63\end{array}$ \\
\hline 7 - VALOR ADICIONADO TOTAL A DISTRIBUIR ( $5+6)$ & 376.032 & 36,72 \\
\hline 8) DISTRIBUIÇÃO DO VALOR ADICIONADO & 376.032 & 100,00 \\
\hline $\begin{array}{l}\text { 8.1) Pessoal e encargos } \\
\text { 8.2) Impostos, taxas e contribuições } \\
\text { 8.3) Juros e aluguéis } \\
\text { 8.4) Juros s/ capital próprio e dividendos } \\
\text { 8.5) Lucros retidos/prejuízo do exercício }\end{array}$ & $\begin{array}{r}122.075 \\
90.089 \\
57.965 \\
34.250 \\
71.653\end{array}$ & $\begin{array}{r}32,46 \\
23,96 \\
15,41 \\
9,11 \\
19,06\end{array}$ \\
\hline * O total do item 8 deve ser exatamente igual ao item 7. & & \\
\hline
\end{tabular}


APÊNDICE 12 - DVA CONSOLIDADA DAS EMPRESAS FORA DA ZONA FRANCA DE MANAUS - SETOR AUTOINDÚSTRIA - 2003 A 2007

DEMONSTRAÇÃO DO VALOR ADICIONADO DO EXERCÍCIO DE 2007

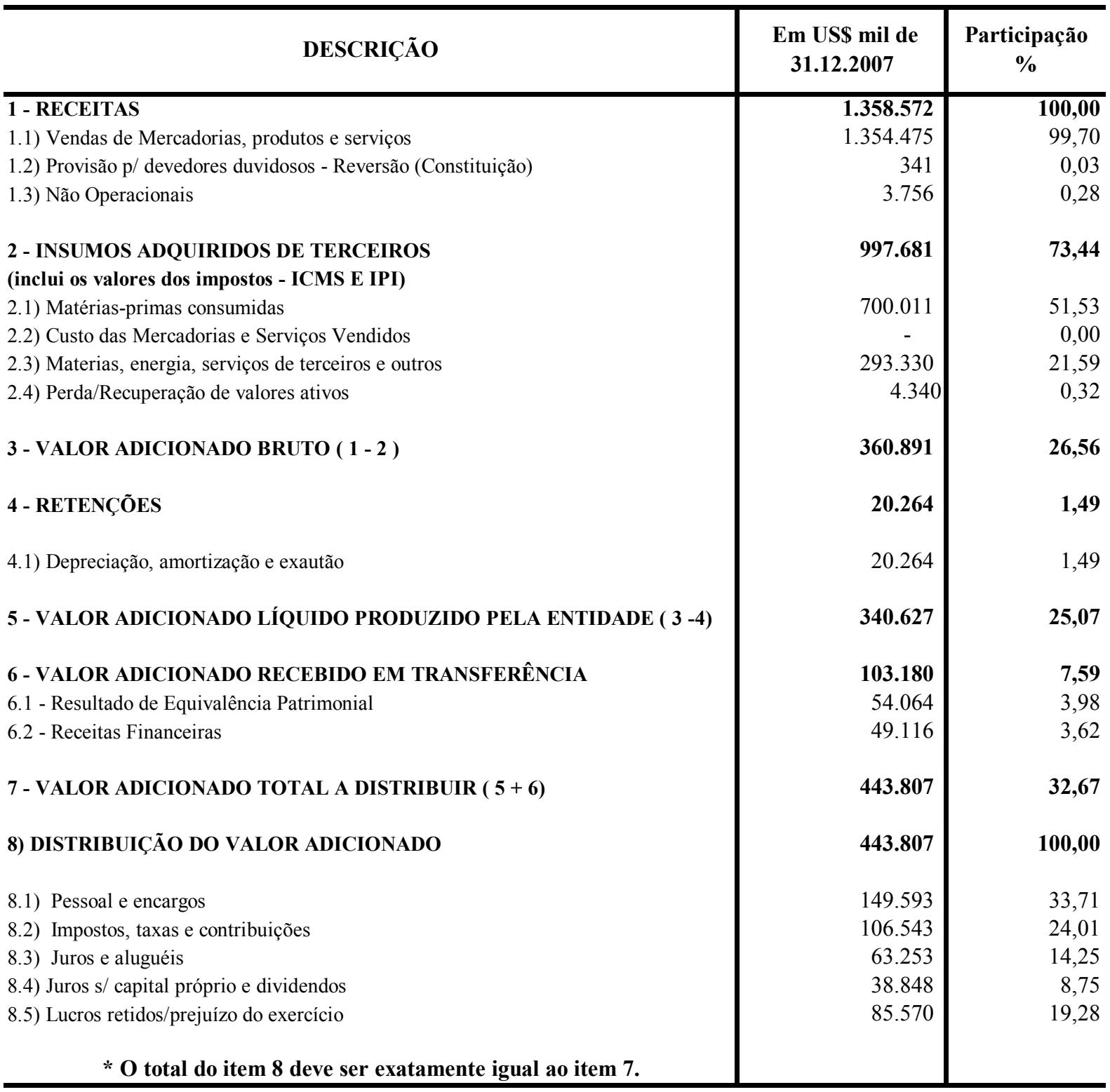



APÊNDICE 13 - DVA CONSOLIDADA DAS EMPRESAS FORA DA ZONA FRANCA DE MANAUS - SETOR BENS DE CONSUMO, INDÚSTRIA DIGITAL E ELETROELETRÔNICO - 2003 A 2007

DEMONSTRAÇÃO DO VALOR ADICIONADO DO EXERCÍCIO DE 2003

\begin{tabular}{|c|c|c|}
\hline DESCRIÇÃO & $\begin{array}{l}\text { Em US\$ mil de } \\
\text { 31.12.2007 }\end{array}$ & $\begin{array}{l}\text { Participação } \\
\text { \% }\end{array}$ \\
\hline $\begin{array}{l}\text { 1 - RECEITAS } \\
\text { 1.1) Vendas de Mercadorias, produtos e serviços } \\
\text { 1.2) Provisão p/ devedores duvidosos - Reversão (Cons tituição) } \\
\text { 1.3) Não Operacionais }\end{array}$ & $\begin{array}{c}\mathbf{5 2 1 . 8 0 8} \\
522.535 \\
(727) \\
-\end{array}$ & $\begin{array}{r}\mathbf{1 0 0 , 0 0} \\
100,14 \\
-0,14 \\
0,00\end{array}$ \\
\hline $\begin{array}{l}2 \text { - INSUMOS ADQUIRIDOS DE TERCEIROS } \\
\text { (inclui os valores dos impostos - ICMS E IPI) }\end{array}$ & 379.181 & 72,67 \\
\hline $\begin{array}{l}\text { 2.1) Matérias-primas con sumidas } \\
\text { 2.2) Custo das Mercadorias e Serviços Vendidos } \\
\text { 2.3) Materias, energia, serviços de terceiros e outros } \\
\text { 2.4) Perda/Recuperação de valores ativos }\end{array}$ & $\begin{array}{r}252.521 \\
84.481 \\
41.437 \\
742\end{array}$ & $\begin{array}{r}48,39 \\
16,19 \\
7,94 \\
0,14\end{array}$ \\
\hline 3 - VALOR ADICIONADO BRUTO ( 1 - 2 ) & 142.627 & 27,33 \\
\hline 4 - RETENÇÕES & 11.699 & 2,24 \\
\hline 4.1) Depreciação, amortização e exau tão & 11.699 & 2,24 \\
\hline 5 - VALOR ADICIONADO LÍQUIDO PRODUZIDO PELA ENTIDADE ( 3 -4) & 130.928 & 25,09 \\
\hline $\begin{array}{l}\text { 6 - VALOR ADICIONADO RECEBIDO EM TRANSFERÊNCIA } \\
6.1 \text { - Resultado de Equivalência Patrimonial } \\
6.2 \text { - Receitas Fin anceiras }\end{array}$ & $\begin{array}{c}19.945 \\
- \\
19.945\end{array}$ & $\begin{array}{l}3,82 \\
0,00 \\
3,82\end{array}$ \\
\hline 7 - VALOR ADICIONADO TOTAL A DISTRIBUIR ( $5+6)$ & $\mathbf{1 5 0 . 8 7 3}$ & 28,91 \\
\hline 8) DISTRIBUIÇÃO DO VALOR ADICIONADO & 150.873 & 100,00 \\
\hline $\begin{array}{l}\text { 8.1) Pessoal e encargos } \\
\text { 8.2) Impostos, taxas e contribuições } \\
\text { 8.3) Juros e aluguéis } \\
\text { 8.4) Juros s/ capital próprio e dividendos } \\
\text { 8.5) Lucros retidos/prejuízo do exercício }\end{array}$ & $\begin{array}{c}40.437 \\
62.436 \\
19.080 \\
- \\
28.920\end{array}$ & $\begin{array}{r}26,80 \\
41,38 \\
12,65 \\
0,00 \\
19,17\end{array}$ \\
\hline * O total do item 8 deve ser e xatamente igual ao item 7. & & \\
\hline
\end{tabular}


APÊNDICE 13 - DVA CONSOLIDADA DAS EMPRESAS FORA DA ZONA FRANCA DE MANAUS - SETOR BENS DE CONSUMO, INDÚSTRIA DIGITAL E ELETROELETRÔNICO - 2003 A 2007

DEMONSTRAÇÃO DO VALOR ADICIONADO DO EXERCÍCIO DE 2004

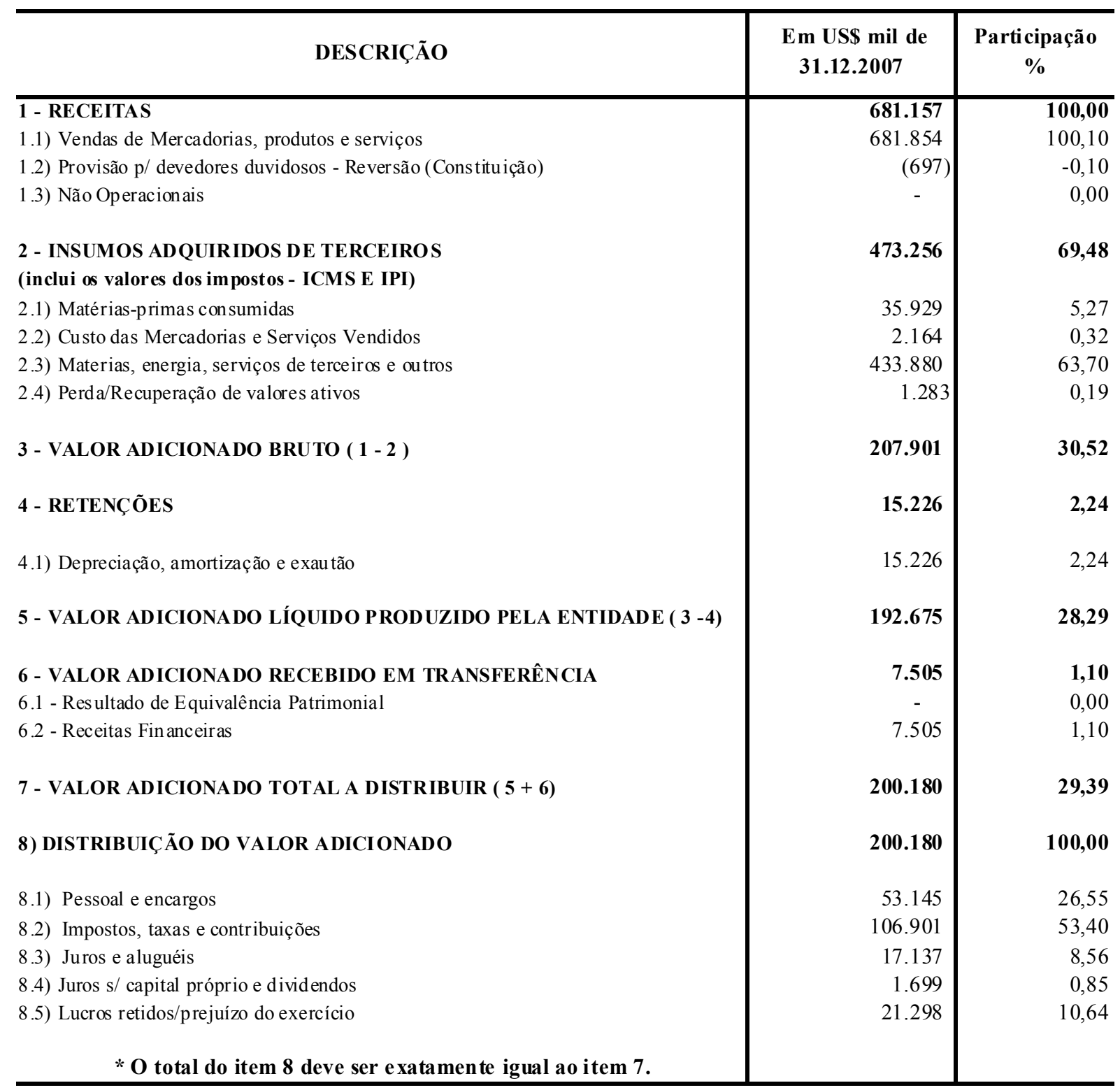


APÊNDICE 13 - DVA CONSOLIDADA DAS EMPRESAS FORA DA ZONA FRANCA DE MANAUS - SETOR BENS DE CONSUMO, INDÚSTRIA DIGITAL E ELETROELETRÔNICO - 2003 A 2007

DEMONSTRAÇÃO DO VALOR ADICIONADO DO EXERCÍCIO DE 2005

\begin{tabular}{|c|c|c|}
\hline DESCRIÇÃO & $\begin{array}{l}\text { Em US\$ mil de } \\
\text { 31.12.2007 }\end{array}$ & $\begin{array}{l}\text { Participação } \\
\%\end{array}$ \\
\hline $\begin{array}{l}\text { 1 - RECEITAS } \\
\text { 1.1) Vendas de Mercadorias, produtos e serviços } \\
\text { 1.2) Provisão p/ devedores duvidosos - Reversão (Constituição) } \\
\text { 1.3) Não Operacionais }\end{array}$ & $\begin{array}{c}8.739 .093 \\
8.776 .638 \\
(47.195) \\
9.650\end{array}$ & $\begin{array}{r}\mathbf{1 0 0 , 0 0} \\
100,43 \\
-0,54 \\
0,11\end{array}$ \\
\hline $\begin{array}{l}2 \text { - INSUMOS ADQUIRIDOS DE TERCEIROS } \\
\text { (inclui os valores dos impostos - ICMS E IPI) }\end{array}$ & 3.936 .953 & 45,05 \\
\hline 2.1) Matérias-primas con sumidas & 1.598 .915 & 18,30 \\
\hline 2.2) Custo das Mercadorias e Serviços Vendidos & 1.129 .511 & 12,92 \\
\hline 2.3) Materias, energia, serviços de terceiros e outros & 1.206 .998 & 13,81 \\
\hline 2.4) Perda/Recuperação de valores ativos & 1.529 & 0,02 \\
\hline 3 - VALOR ADICIONADO BRUTO ( 1 - 2 ) & 4.802 .140 & 54,95 \\
\hline 4 - RETENÇÕES & 124.660 & 1,43 \\
\hline 4.1) Depreciação, amortização e exau tão & 124.660 & 1,43 \\
\hline 5 - VALOR ADICIONADO LÍQUIDO PRODUZIDO PELA ENTIDADE ( 3 -4) & 4.677 .480 & 53,52 \\
\hline 6 - VALOR ADICIONADO RECEBIDO EM TRANSFERÊNCIA & 204.072 & 2,34 \\
\hline 6.1 - Resultado de Equivalência Patrimonial & 11.749 & 0,13 \\
\hline 6.2 - Receitas Financeiras & 192.323 & 2,20 \\
\hline 7 - VALOR ADICIONADO TOTAL A DISTRIBUIR ( 5 + 6) & 4.881 .552 & 55,86 \\
\hline 8) DISTRIBUIÇÃO DO VALOR ADICIONADO & 4.881 .552 & 100,00 \\
\hline 8.1) Pessoal e encargos & 435.906 & 8,93 \\
\hline 8.2) Impostos, taxas e contribuições & 3.506 .975 & 71,84 \\
\hline 8.3) Juros e aluguéis & 194.538 & 3,99 \\
\hline 8.4) Juros s/ capital próprio e dividendos & 646.448 & 13,24 \\
\hline 8.5) Lucros retidos/prejuízo do exercício & 97.685 & 2,00 \\
\hline
\end{tabular}


APÊNDICE 13 - DVA CONSOLIDADA DAS EMPRESAS FORA DA ZONA FRANCA DE MANAUS - SETOR BENS DE CONSUMO, INDÚSTRIA DIGITAL E ELETROELETRÔNICO - 2003 A 2007

DEMONSTRAÇÃO DO VALOR ADICIONADO DO EXERCÍCIO DE 2006

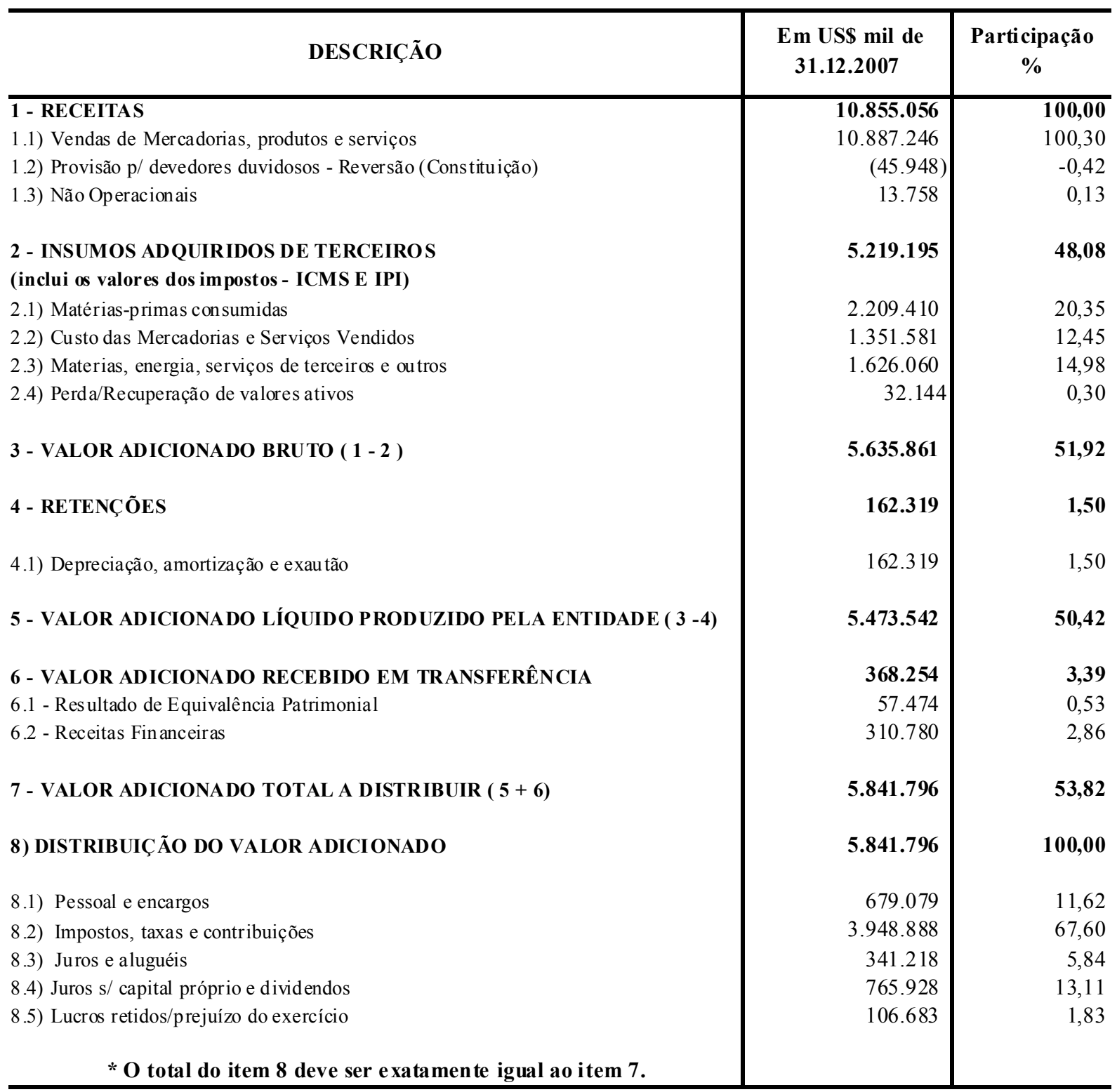


APÊNDICE 13 - DVA CONSOLIDADA DAS EMPRESAS FORA DA ZONA FRANCA DE MANAUS - SETOR BENS DE CONSUMO, INDÚSTRIA DIGITAL E ELETROELETRÔNICO - 2003 A 2007

DEMONSTRAÇÃO DO VALOR ADICIONADO DO EXERCÍCIO DE 2007

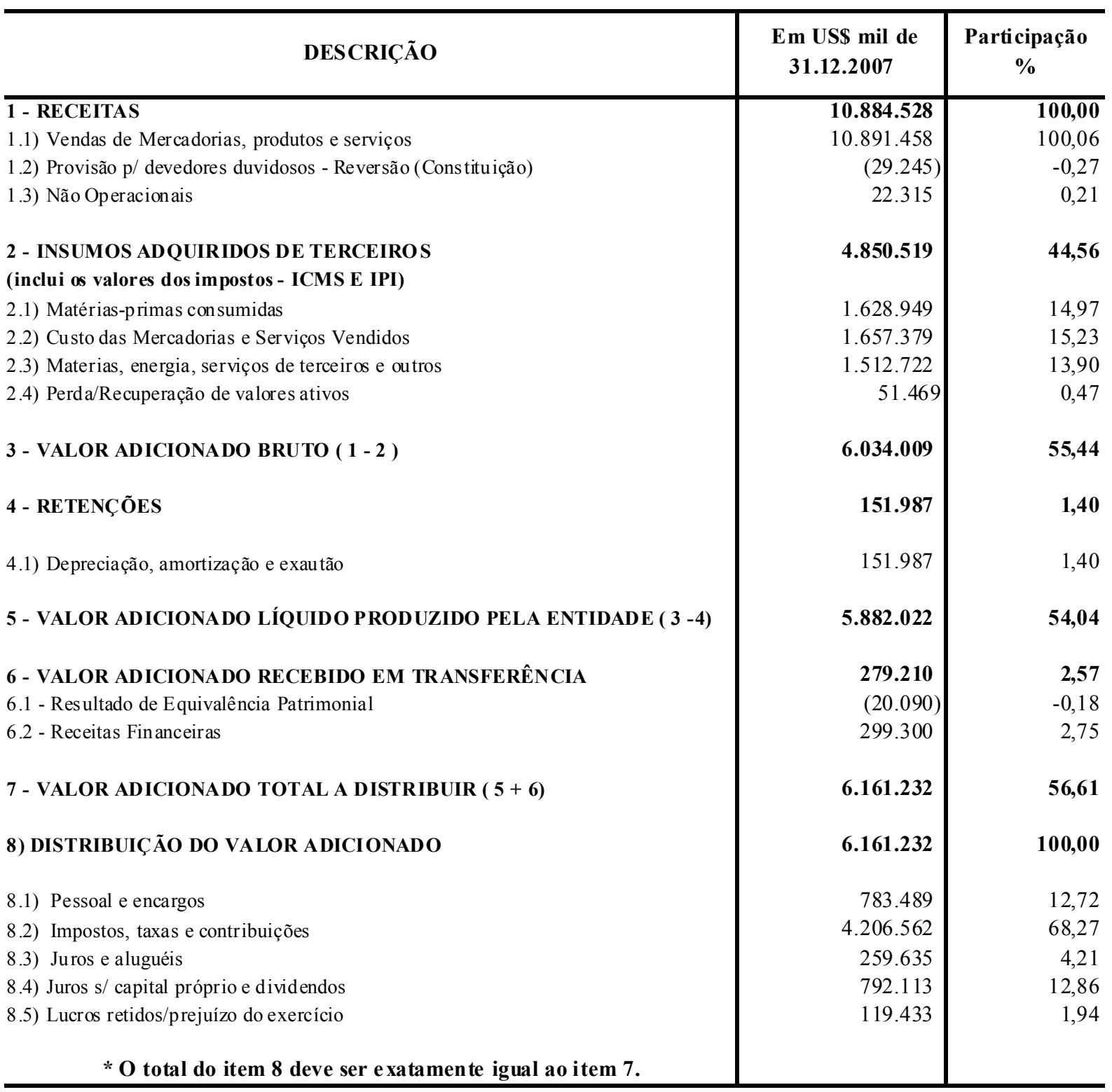



APÊNDICE 14 - DVA CONSOLIDADA DAS EMPRESAS PARES - 2003 A 2007

DEMONSTRAÇÃO DO VALOR ADICIONADO DO EXERCÍCIO DE 2003

\begin{tabular}{|c|c|c|}
\hline DESCRIÇÃO & $\begin{array}{l}\text { Em US\$ mil de } \\
\text { 31.12.2007 }\end{array}$ & $\begin{array}{l}\text { Participação } \\
\%\end{array}$ \\
\hline $\begin{array}{l}\text { 1 - RECEITAS } \\
\text { 1.1) Vendas de Mercadorias, produtos e serviços } \\
\text { 1.2) Provisão p/ devedores duvidosos - Reversão (Constituição) } \\
\text { 1.3) Não Operacionais }\end{array}$ & $\begin{array}{r}3.497 .260 \\
3.437 .549 \\
54.939 \\
4.772\end{array}$ & $\begin{array}{r}\mathbf{1 0 0 , 0 0} \\
98,29 \\
1,57 \\
0,14\end{array}$ \\
\hline $\begin{array}{l}2 \text { - INSUMOS ADQUIRIDOS DE TERCEIROS } \\
\text { (inclui os valores dos impostos - ICMS E IPI) }\end{array}$ & 2.276.077 & 65,08 \\
\hline 2.1) Matérias-primas con sumidas & 1.032 .867 & 29,53 \\
\hline 2.2) Custo das Mercadorias e Serviços Vendidos & 797.668 & 22,81 \\
\hline 2.3) Materias, energia, serviços de terceiros e outros & 429.823 & 12,29 \\
\hline 2.4) Perda/Recuperação de valores ativos & 15.719 & 0,45 \\
\hline 3 - VALOR ADICIONADO BRUTO ( 1 - 2 ) & 1.221.183 & 34,92 \\
\hline 4 - RETENÇÕES & 141.164 & 4,04 \\
\hline 4.1) Depreciação, amortização e exau tão & 141.164 & 4,04 \\
\hline 5 - VALOR ADICIONADO LÍQUIDO PRODUZIDO PELA ENTIDADE ( 3 -4) & 1.080 .019 & 30,88 \\
\hline 6 - VALOR ADICIONADO RECEBIDO EM TRANSFERÊNCIA & 366.645 & 10,48 \\
\hline 6.1 - Resultado de Equivalência Patrimonial & 82.558 & 2,36 \\
\hline 6.2 - Receitas Fin anceiras & 284.087 & 8,12 \\
\hline 7 - VALOR ADICIONADO TOTAL A DISTRIBUIR ( $5+6)$ & 1.446 .664 & 41,37 \\
\hline 8) DISTRIBUIÇÃO DO VALOR ADICIONADO & 1.446 .664 & 100,00 \\
\hline 8.1) Pessoal e encargos & 393.095 & 27,17 \\
\hline 8.2) Impostos, taxas e contribuições & 520.659 & 35,99 \\
\hline 8.3) Juros e aluguéis & 414.024 & 28,62 \\
\hline 8.4) Juros s/ capital próprio e dividendos & 30.566 & 2,11 \\
\hline 8.5) Lucros retidos/prejuízo do exercício & 88.320 & 6,11 \\
\hline
\end{tabular}


APÊNDICE 14 - DVA CONSOLIDADA DAS EMPRESAS PARES - 2003 A 2007

DEMONSTRAÇÃO DO VALOR ADICIONADO DO EXERCÍCIO DE 2004

\begin{tabular}{|c|c|c|}
\hline DESCRIÇÃO & $\begin{array}{l}\text { Em US\$ mil de } \\
\text { 31.12.2007 }\end{array}$ & $\begin{array}{l}\text { Participação } \\
\%\end{array}$ \\
\hline $\begin{array}{l}\text { - RECEITAS } \\
\text { 1.1) Vendas de Mercadorias, produtos e serviços } \\
\text { 1.2) Provisão p/ devedores duvidosos - Reversão (Constituição) } \\
\text { 1.3) Não Operacionais }\end{array}$ & $\begin{array}{r}4.466 .038 \\
4.457 .689 \\
2.313 \\
6.036\end{array}$ & $\begin{array}{r}\mathbf{1 0 0 , 0 0} \\
99,81 \\
0,05 \\
0,14\end{array}$ \\
\hline $\begin{array}{l}2 \text { - INSUMOS ADQUIRIDOS DE TERCEIROS } \\
\text { (inclui os valores dos impostos - ICMS E IPI) }\end{array}$ & 2.658.442 & 59,53 \\
\hline $\begin{array}{l}\text { 2.1) Matérias-primas consumidas } \\
\text { 2.2) Custo das Mercadorias e Serviços Vendidos } \\
\text { 2.3) Materias, energia, serviços de terceiros e outros } \\
\text { 2.4) Perda/Recuperação de valores ativos }\end{array}$ & $\begin{array}{r}1.276 .122 \\
951.983 \\
393.276 \\
37.061\end{array}$ & $\begin{array}{r}28,57 \\
21,32 \\
8,81 \\
0,83\end{array}$ \\
\hline 3 - VALOR ADICIONADO BRUTO ( 1 - 2 ) & 1.807.596 & 40,47 \\
\hline 4 - RETENÇÕES & 119.033 & 2,67 \\
\hline 4.1) Depreciação, amortização e exau tão & 119.033 & 2,67 \\
\hline 5 - VALOR ADICIONADO LÍQUIDO PRODUZIDO PELA ENTIDADE ( 3 -4) & 1.688.563 & 37,81 \\
\hline $\begin{array}{l}\text { 6 - VALOR ADICIONADO RECEBIDO EM TRANSFERÊNCIA } \\
6.1 \text { - Resultado de Equivalência Patrimonial } \\
6.2 \text { - Receitas Fin anceiras }\end{array}$ & $\begin{array}{l}272.262 \\
100.728 \\
171.534\end{array}$ & $\begin{array}{l}\mathbf{6 , 1 0} \\
2,26 \\
3,84\end{array}$ \\
\hline 7 - VALOR ADICIONADO TOTAL A DISTRIBUIR $(5+6)$ & 1.960 .825 & 43,91 \\
\hline 8) DISTRIBUIÇÃO DO VALOR ADICIONADO & 1.960 .825 & 100,00 \\
\hline $\begin{array}{l}\text { 8.1) Pessoal e encargos } \\
\text { 8.2) Impostos, taxas e contribuições } \\
\text { 8.3) Juros e aluguéis } \\
\text { 8.4) Juros s/ capital próprio e dividendos } \\
\text { 8.5) Lucros retidos/prejuízo do exercício }\end{array}$ & $\begin{array}{r}469.735 \\
687.176 \\
416.433 \\
40.487 \\
346.994\end{array}$ & $\begin{array}{r}23,96 \\
35,05 \\
21,24 \\
2,06 \\
17,70\end{array}$ \\
\hline e ser exa & & \\
\hline
\end{tabular}


APÊNDICE 14 - DVA CONSOLIDADA DAS EMPRESAS PARES - 2003 A 2007

DEMONSTRAÇÃO DO VALOR ADICIONADO DO EXERCÍCIO DE 2005

\begin{tabular}{|c|c|c|}
\hline DESCRIÇÃO & $\begin{array}{c}\text { Em US\$ mil de } \\
\text { 31.12.2007 }\end{array}$ & $\begin{array}{c}\text { Participação } \\
\%\end{array}$ \\
\hline $\begin{array}{l}\text { 1 - RECEITAS } \\
\text { 1.1) Vendas de Mercadorias, produtos e serviços } \\
\text { 1.2) Provisão p/ devedores duvidosos - Reversão (Constituição) } \\
\text { 1.3) Não Operacionais }\end{array}$ & $\begin{array}{r}3.427 .392 \\
3.421 .758 \\
(1.700) \\
7.334\end{array}$ & $\begin{array}{r}\mathbf{1 0 0 , 0 0} \\
99,84 \\
-0,05 \\
0,21\end{array}$ \\
\hline $\begin{array}{l}2 \text { - INSUMOS ADQUIRIDOS DE TERCEIROS } \\
\text { (inclui os valores dos impostos - ICMS E IPI) }\end{array}$ & 1.984.999 & 57,92 \\
\hline $\begin{array}{l}\text { 2.1) Matérias-primas con sumidas } \\
\text { 2.2) Custo das Mercadorias e Serviços Vendidos } \\
\text { 2.3) Materias, energia, serviços de terceiros e outros } \\
\text { 2.4) Perda/Recuperação de valores ativos }\end{array}$ & $\begin{array}{r}996.531 \\
635.898 \\
355.389 \\
-2.819\end{array}$ & $\begin{array}{r}29,08 \\
18,55 \\
10,37 \\
-0,08\end{array}$ \\
\hline 3 - VALOR ADICIONADO BRUTO ( 1 - 2 ) & 1.442.393 & 42,08 \\
\hline 4 - RETENÇÕES & 80.132 & 2,34 \\
\hline 4.1) Depreciação, amortização e exau tão & 80.132 & 2,34 \\
\hline 5 - VALOR ADICIONADO LÍQUIDO PRODUZIDO PELA ENTIDADE ( 3 -4) & 1.362 .261 & 39,75 \\
\hline $\begin{array}{l}\text { 6 - VALOR ADICIONADO RECEBIDO EM TRANSFERÊNCIA } \\
6.1 \text { - Resultado de Equivalência Patrimonial } \\
6.2 \text { - Receitas Fin anceiras }\end{array}$ & $\begin{array}{r}139.488 \\
6.103 \\
133.385\end{array}$ & $\begin{array}{l}\mathbf{4 , 0 7} \\
0,18 \\
3,89\end{array}$ \\
\hline 7 - VALOR ADICIONADO TOTAL A DISTRIBUIR ( $5+6)$ & 1.501.749 & 43,82 \\
\hline 8) DISTRIBUIÇÃO DO VALOR ADICIONADO & 1.501.749 & 100,00 \\
\hline $\begin{array}{l}\text { 8.1) Pessoal e encargos } \\
\text { 8.2) Impostos, taxas e contribuições } \\
\text { 8.3) Juros e aluguéis } \\
\text { 8.4) Juros s/ capital próprio e dividendos } \\
\text { 8.5) Lucros retidos/prejuízo do exercício }\end{array}$ & $\begin{array}{r}520.177 \\
664.478 \\
251.137 \\
39.714 \\
26.243\end{array}$ & $\begin{array}{r}34,64 \\
44,25 \\
16,72 \\
2,64 \\
1,75\end{array}$ \\
\hline * O total do item 8 deve ser e xatamente igual ao item 7. & & \\
\hline
\end{tabular}


APÊNDICE 14 - DVA CONSOLIDADA DAS EMPRESAS PARES - 2003 A 2007

DEMONSTRAÇÃO DO VALOR ADICIONADO DO EXERCÍCIO DE 2006

\begin{tabular}{|c|c|c|}
\hline DESCRIÇÃO & $\begin{array}{l}\text { Em US\$ mil de } \\
\text { 31.12.2007 }\end{array}$ & $\begin{array}{l}\text { Participação } \\
\%\end{array}$ \\
\hline $\begin{array}{l}\text { - RECEITAS } \\
\text { 1.1) Vendas de Mercadorias, produtos e serviços } \\
\text { 1.2) Provisão p/ devedores duvidosos - Reversão (Constituição) } \\
\text { 1.3) Não Operacionais }\end{array}$ & $\begin{array}{r}\mathbf{3 . 0 0 3 . 2 4 0} \\
2.979 .941 \\
21.517 \\
1.782\end{array}$ & $\begin{array}{r}\mathbf{1 0 0 , 0 0} \\
99,22 \\
0,72 \\
0,06\end{array}$ \\
\hline $\begin{array}{l}2 \text { - INSUMOS ADQUIRIDOS DE TERCEIROS } \\
\text { (inclui os valores dos impostos - ICMS E IPI) }\end{array}$ & 1.469 .143 & 48,92 \\
\hline $\begin{array}{l}\text { 2.1) Matérias-primas con sumidas } \\
\text { 2.2) Custo das Mercadorias e Serviços Vendidos } \\
\text { 2.3) Materias, energia, serviços de terceiros e outros } \\
\text { 2.4) Perda/Recuperação de valores ativos }\end{array}$ & $\begin{array}{r}396.963 \\
791.434 \\
238.635 \\
42.111\end{array}$ & $\begin{array}{r}13,22 \\
26,35 \\
7,95 \\
1,40\end{array}$ \\
\hline 3 - VALOR ADICIONADO BRUTO ( 1 - 2 ) & 1.534.097 & 51,08 \\
\hline 4 - RETENÇÕES & 77.490 & 2,58 \\
\hline 4.1) Depreciação, amortização e exau tão & 77.490 & 2,58 \\
\hline 5 - VALOR ADICIONADO LÍQUIDO PRODUZIDO PELA ENTIDADE ( 3 -4) & 1.456 .607 & 48,50 \\
\hline $\begin{array}{l}\text { 6 - VALOR ADICIONADO RECEBIDO EM TRANSFERÊNCIA } \\
6.1 \text { - Resultado de Equivalência Patrimonial } \\
6.2 \text { - Receitas Financeiras }\end{array}$ & $\begin{array}{c}\mathbf{1 0 8 . 5 2 8} \\
(15.946) \\
124.474\end{array}$ & $\begin{array}{r}3,61 \\
-0,53 \\
4,14\end{array}$ \\
\hline 7 - VALOR ADICIONADO TOTAL A DISTRIBUIR $(5+6)$ & 1.565 .135 & 52,11 \\
\hline 8) DISTRIBUIÇÃO DO VALOR ADICIONADO & 1.565 .135 & 100,00 \\
\hline $\begin{array}{l}\text { 8.1) Pessoal e encargos } \\
\text { 8.2) Impostos, taxas e contribuições } \\
\text { 8.3) Juros e aluguéis } \\
\text { 8.4) Juros s/ capital próprio e dividendos } \\
\text { 8.5) Lucros retidos/prejuízo do exercício }\end{array}$ & $\begin{array}{r}467.345 \\
920.000 \\
165.559 \\
13.864 \\
(1.633)\end{array}$ & $\begin{array}{r}29,86 \\
58,78 \\
10,58 \\
0,89 \\
-0,10\end{array}$ \\
\hline * O total & & \\
\hline
\end{tabular}


APÊNDICE 14 - DVA CONSOLIDADA DAS EMPRESAS PARES - 2003 A 2007

DEMONSTRAÇÃO DO VALOR ADICIONADO DO EXERCÍCIO DE 2007

\begin{tabular}{|c|c|c|}
\hline DESCRIÇÃO & $\begin{array}{l}\text { Em US\$ mil de } \\
\text { 31.12.2007 }\end{array}$ & $\begin{array}{l}\text { Participação } \\
\%\end{array}$ \\
\hline $\begin{array}{l}\text { - RECEITAS } \\
\text { 1.1) Vendas de Mercadorias, produtos e serviços } \\
\text { 1.2) Provisão p/ devedores duvidosos - Reversão (Constituição) } \\
\text { 1.3) Não Operacionais }\end{array}$ & $\begin{array}{r}3.450 .219 \\
3.451 .680 \\
(6.666) \\
5.205\end{array}$ & $\begin{array}{r}\mathbf{1 0 0 , 0 0} \\
100,04 \\
-0,19 \\
0,15\end{array}$ \\
\hline $\begin{array}{l}2 \text { - INSUMOS ADQUIRIDOS DE TERCEIROS } \\
\text { (inclui os valores dos impostos - ICMS E IPI) }\end{array}$ & 1.799 .126 & 52,15 \\
\hline 2.1) Matérias-primas con sumidas & 634.770 & 18,40 \\
\hline 2.2) Custo das Mercadorias e Serviços Vendidos & 778.637 & 22,57 \\
\hline 2.3) Materias, energia, serviços de terceiros e outros & 376.408 & 10,91 \\
\hline 2.4) Perda/Recuperação de valores ativos & 9.311 & 0,27 \\
\hline 3 - VALOR ADICIONADO BRUTO ( 1 - 2 ) & 1.651 .093 & 47,85 \\
\hline 4 - RETENÇÕES & 81.142 & 2,35 \\
\hline 4.1) Depreciação, amortização e exau tão & 81.142 & 2,35 \\
\hline 5 - VALOR ADICIONADO LÍQUIDO PRODUZIDO PELA ENTIDADE ( 3 -4) & 1.569 .951 & 45,50 \\
\hline 6 - VALOR ADICIONADO RECEBIDO EM TRANSFERÊNCIA & 64.373 & 1,87 \\
\hline 6.1 - Resultado de Equivalência Patrimonial & 4.929 & 0,14 \\
\hline 6.2 - Receitas Fin anceiras & 59.444 & 1,72 \\
\hline 7 - VALOR ADICIONADO TOTAL A DISTRIBUIR ( $5+6$ ) & 1.634 .324 & 47,37 \\
\hline 8) DISTRIBUIÇÃO DO VALOR ADICIONADO & 1.634 .324 & 100,00 \\
\hline 8.1) Pessoal e encargos & 712.584 & 43,60 \\
\hline 8.2) Impostos, taxas e contribuições & 732.312 & 44,81 \\
\hline 8.3) Juros e aluguéis & 104.921 & 6,42 \\
\hline 8.4) Juros s/ capital próprio e dividendos & 57.438 & 3,51 \\
\hline 8.5) Lucros retidos/prejuízo do exercício & 27.069 & 1,66 \\
\hline
\end{tabular}

